JOINT TRANSPORTATION RESEARCH PROGRAM

FHWA/IN/JTRP-2010/12

Final Report

A SYNTHESIS OF OVERWEIGHT TRUCK PERMITTING

M. K. Bilal

M. Irfan

A. Anwaar

S. Labi

K. C. Sinha

September 2010 


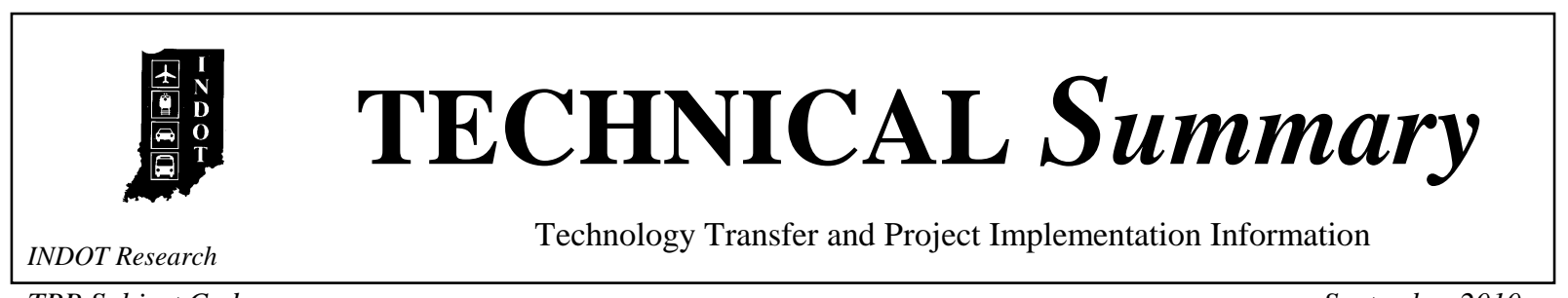

TRB Subject Code:

Publication No.: FHWA/IN/JTRP-2010/12, SPR-3471

September 2010

Final Report

\section{A SYNTHESIS OF OVERWEIGHT TRUCK PERMITTING}

\section{Introduction}

For purposes of safety and system preservation, trucking operations are regulated through federal and state legislation and policies. Under certain circumstances, special permits are granted to truck operators to allow them to exceed the specified operational restrictions. The Indiana DOT bears the responsibility to adopt policies for highway operations and cost allocation that retain and attract heavy industry on one hand but also avoid premature and accelerated highway deterioration on the other hand. Over the decades, the dynamic nature of the national and regional social-economic development translates into changing distributions and patterns of commercial vehicle movements. Thus, there is a need to continually review the truck weight permitting practices in
Indiana in relation to those of neighboring states. This involves documentation, assessment, and comparison of the agency practices on the basis of the simplicity and ease of the permitting process for the permit applicant; convenience of the process (for the applicant) with respect to vehicle attributes, the fee structure for extra legal weights and sizes, and basis for such fees. There is also a need to document the revenue streams from the existing permit process, and to synthesize existing methods that quantify the impacts of additional payloads on pavement deterioration and subsequently, on pavement repair costs. This study addresses these issues.

\section{Findings}

The study determined that while the upper thresholds (dimensions and weights) for legal trucking operation are generally the same for each state, those for extra legal dimensions and weights vary considerably across the states. Also, the findings from the literature review, internet search, and phone interviews show that there is a great deal of variability in truck permit fees and permitting criteria across the states. The key criteria include: the extents to which size attributes (length, width, height) are in excess of the legal values, distance traveled by the overweight/oversize truck, type of load carried, and axle spacing. Furthermore, it was observed that no Midwest state has adopted explicitly the weight-distance concept for its overweight trucks. However, in the states of Indiana, Ohio, and Illinois, the fee structures for overweight vehicles includes weight levels and extents of travel; thus their fee structures resemble that of a weight-distance fee structure.

From the perspective of overweight and oversize thresholds and associated permit fees, it was observed that a number of states such as Indiana appear to be more favorable to trucking because they have relatively high upper thresholds for defining what an overweight truck is, and/or have relatively lower fees for overweight trucks. However, as demonstrated in the excel spreadsheet case studies that accompany this report, the differences in fees incurred by truckers across the state are significantly influenced by factors including the trip circumstances, permitting criteria, and trip frequency and distance. As such, a holistic assessment and comparison across the states can only be carried out on a case-by-case basis.

The study documented the revenue streams obtained from the permits issued for extra-legal trucking operations: these were found to be approximately $\$ 12$ million annually. The study also briefly addressed the issue of revenue neutrality: it was seen from the literature and from phone interviews that highway agencies that had switched from a single-trip permit system to an annual flat fee permit system had benefited from cost savings due to reduced monitoring efforts of truck trip but had lost significant revenue overall. 
Using data from a past national study, the report provides nomographs with which INDOT can quantify the increase in pavement damage (and hence repair costs) that can be expected due to additional payload increases for a given axle configuration; and the reduction in pavement damage due to the increase of axles on a truck of a given payload. However, as these relationships between truck load pavement damage costs are based on national level data, there is a need to update these costs using data from Indiana.

\section{Implementation}

This study can be used by personnel at a number of divisions, offices, program areas, and units at INDOT to assess the consequences of truck weight policies on the condition and longevity of assets within their jurisdiction. These include the Indiana Toll Road, the Divisions of Freight Mobility, Economic Opportunity, and the Indiana Department of Revenue. These offices have a stake in knowing the potential impact of any changes on vehicle license fees and overweight truck permits on the revenue generated from each of these fee structures, and the impact of pavement damage in response to overweight policy changes. The developed Excel spreadsheets can be used to determine, for a single truck or truck fleet comprised of trucks of various axle distributions, weights, and sizes, the impacts of different hypothetical fee structures in terms of the annual permit fee expenditure incurred by truckers. The spreadsheets can also be implemented by the Indiana Department of Revenue (INDOR) who has a stake in quantifying the potential impact of different fee structures on revenue accrued to that agency. The above-named INDOT offices are interested in quantifying the potential pavement damage impacts of different overweight policies. In this respect, the nomographs developed in this study can be used by the Implementor to determine the pavement damage cost incurred by various truck loads and axle configurations. The report also presents a methodology that INDOT could use to develop similar nomographs in future, for different problem scenarios. The study also provides a premise for a subsequent comprehensive investigation of the various costs and benefits associated with alternative policies and fee structures for overweight trucks, in terms of pavement and bridge damage, and administration and enforcement efforts.

In sum, implementing the study product is expected to enhance assist the Indiana Department of Transportation to update and streamline its permitting process. The agency is thus expected to be in a better position to monitor the impacts of the use of its highways by overweight/oversize vehicles, update its permit fee structures, and ultimately, preserve its investments in highway infrastructure and to make the state more competitive economically.

A core group of five persons at INDOT under advisement of FHWA can, over the following months, further define and select implementation strategies relative to agency practices. The principal mission of this implementing panel would be to advance and institutionalize the most practicable methods outlined in this research report.

\section{Contacts}

For more information:

Prof. Samuel Labi

Principal Investigator

School of Civil Engineering

Purdue University

West Lafayette IN 47907

Phone: (765) 494-5926

Fax: (765) 496-7996

Prof. Kumares C. Sinha

Co-Principal Investigator

School of Civil Engineering

Purdue University

West Lafayette IN 47907

Phone: (765) 494-5926

Fax: (765) 496-7996
Indiana Department of Transportation

Office of Research, 1205 Montgomery Street, P.O. Box

2279, West Lafayette, IN 47906

Phone: (765) 463-1521

Fax: (765) 497-1665

Purdue University

Joint Transportation Research Program

School of Civil Engineering

West Lafayette, IN 47907-1284

Phone: (765) 494-9310

Fax: (765) 496-1105 
FINAL REPORT

FHWA/IN/JTRP-2010/12

\title{
A SYNTHESIS OF OVERWEIGHT TRUCK PERMITTING
}

\author{
By \\ Muhammad K. Bilal \\ Muhammad Irfan \\ Anwaar Ahmed \\ (Graduate Students) \\ Samuel Labi \\ Assistant Professor of Civil Engineering \\ and \\ Kumares C. Sinha \\ Olson Distinguished Professor of Civil Engineering \\ Purdue University
Joint Transportation Research Program
SPR-3471
Prepared in Cooperation with the
The U.S. Department of Transportation
Federal Highway Administration \\ Indiana Department of Transportation and
}

The contents of this report reflect the views of the authors who are responsible for the facts and the accuracy of the data presented herein. The contents do not necessarily reflect the official views of the Federal Highway Administration and the Indiana Department of Transportation. The report does not constitute a standard, a specification, or a regulation.

Purdue University

West Lafayette, Indiana, 47907

September 2010 
TECHNICAL REPORT STANDARD TITLE PAGE

\begin{tabular}{|c|c|c|}
\hline $\begin{array}{l}\text { 1. Report No. } \\
\text { FHWA/IN/JTRP-2010/12 }\end{array}$ & 2. Government Accession No. & 3. Recipient's Catalog No. \\
\hline \multirow{2}{*}{\multicolumn{2}{|c|}{$\begin{array}{l}\text { 4. Title and Subtitle } \\
\text { A Synthesis of Overweight Truck Permitting }\end{array}$}} & $\begin{array}{l}\text { 5. Repor } \\
\text { Septemb }\end{array}$ \\
\hline & & 6. Performing Organization Code \\
\hline \multirow{2}{*}{\multicolumn{2}{|c|}{$\begin{array}{l}\text { 7. Author(s) } \\
\text { Muhammad K. Bilal,Muhammad Irfan, Anwaar Ahmed, Samuel Labi, and Kumares C. } \\
\text { Sinha }\end{array}$}} & 8. Performing Organization Report No. \\
\hline & & FHWA/IN/JTRP-2010/12 \\
\hline \multirow{2}{*}{\multicolumn{2}{|c|}{$\begin{array}{l}\text { 9. Performing Organization Name and Address } \\
\text { Joint Transportation Research Program } \\
\text { 1284 Civil Engineering Building, 550 Stadium Mall Drive, Purdue } \\
\text { University, West Lafayette, IN 47907-1284 }\end{array}$}} & 0. \\
\hline & & $\begin{array}{l}\text { 11. Contract or Grant No. } \\
\text { SPR-3471 }\end{array}$ \\
\hline \multirow{2}{*}{\multicolumn{2}{|c|}{$\begin{array}{l}\text { 12. Sponsoring Agency Name and Address } \\
\text { Indiana Department of Transportation } \\
\text { State Office Building, } 100 \text { North Senate Avenue } \\
\text { Indianapolis, IN } 46204\end{array}$}} & 13. Type of Report and Period \\
\hline & & 14. Sponsoring Agency Code \\
\hline \multicolumn{3}{|c|}{$\begin{array}{l}\text { 15. Supplementary Notes } \\
\text { Prepared in cooperation with the Indiana Department of Transportation and Federal Highway Administration. }\end{array}$} \\
\hline \multicolumn{3}{|c|}{ 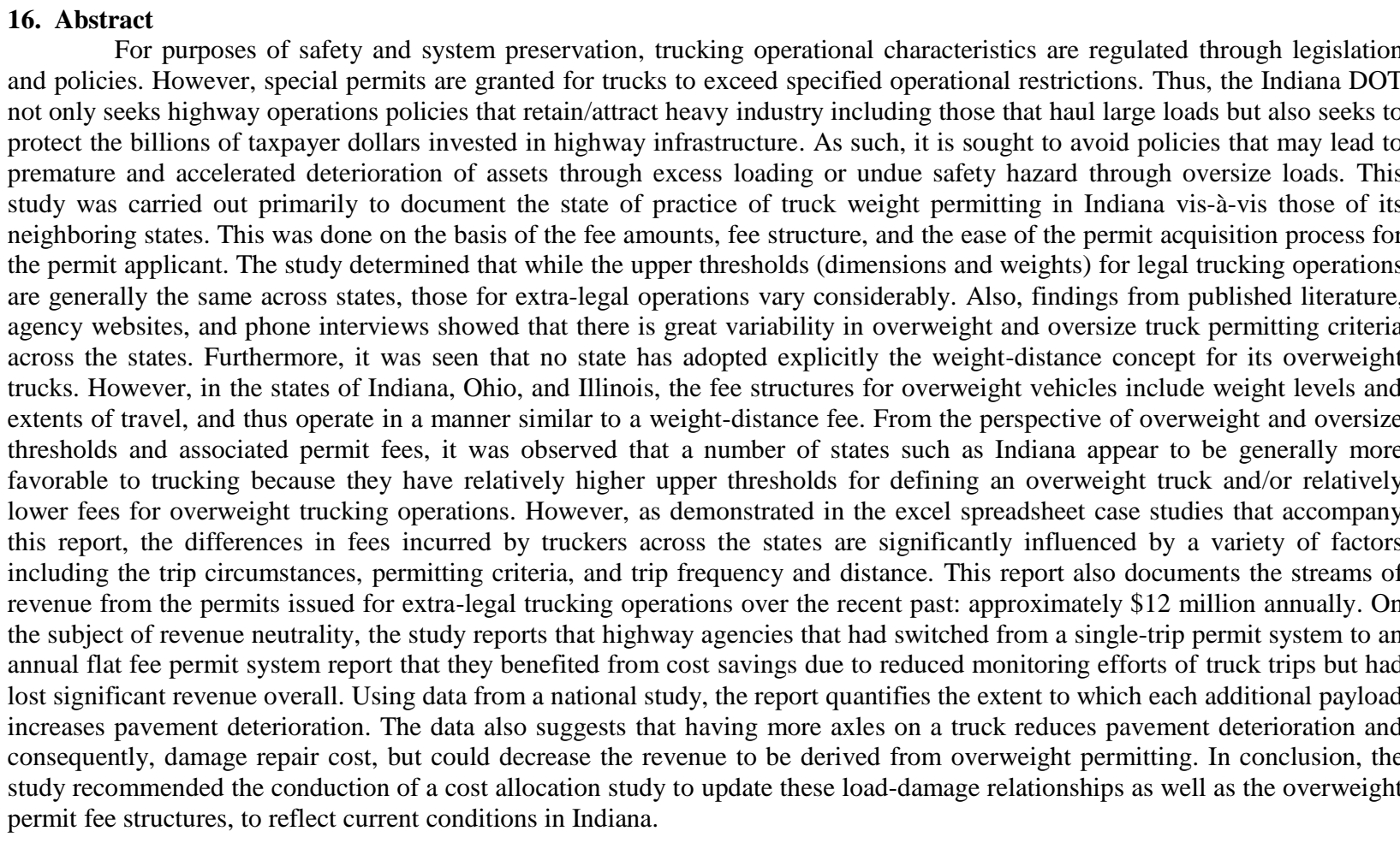 } \\
\hline
\end{tabular}

\section{Key Words}

Overweight and Over Size Trucks, Overweight/Oversize Truck Permitting, Pavement Damage Cost.
18. Distribution Statement

No restrictions. This document is available to the public through the National Technical Information Service, Springfield, VA 22161

\begin{tabular}{|c|c|c|c|}
\hline $\begin{array}{l}\text { 19. Security Classif. (of this report) } \\
\text { Unclassified }\end{array}$ & $\begin{array}{l}\text { 20. Security Classif. (of this page) } \\
\text { Unclassified }\end{array}$ & $\begin{array}{l}\text { 21. No. of Pages } \\
105\end{array}$ & 22. Price \\
\hline
\end{tabular}

Form DOT F 1700.7 (8-69) 


\section{ACKNOWLEDGMENTS}

The authors hereby acknowledge the constant support provided by Leigh Morris, deputy commissioner of the Indiana Department of Transportation (INDOT). We also appreciate the vital advice and support of the following individuals throughout the conduction of the study: Mr. Clark Snyder of INDOT Toll Road Office, Mr. Keith Bucklew, Director, INDOT's Division of Freight Mobility, Mr. Edward Pollack, Director, INDOT’s Innovation Office, Mr. Guy Boruff, Director, INDOT's Public Safety Operations Division (PSOps), Ms. Claudia Mellot of the Indiana Department of Revenue, Ms. Corina Harmless, formerly of the Indiana Department of Revenue, and Dr. Sangdo Victor Hong of INDOT's Research Office and Dr. Scott Newbolds formerly of INDOT's Research Office. Also, the efforts of Dr. Samy Noureldin in steering this project to its conclusion are also appreciated. 
TABLE OF CONTENTS

\begin{tabular}{|c|c|}
\hline & Page \\
\hline LIST OF TABLES & vi \\
\hline LIST OF FIGURES ..... & vii \\
\hline CHAPTER 1 INTRODUCTION & \\
\hline 1.1 Background Information .... & 1 \\
\hline 1.2 Study Objectives ................. & 2 \\
\hline 1.3 Contents of this Report ........... & 3 \\
\hline CHAPTER 2 TRUCK PERMITTING - STATE OF PRACTICE & 4 \\
\hline 2.1 The State of Practice in Indiana & 4 \\
\hline 2.2 Comparison of the Practice in Indiana and at Neighboring States ...................... & 5 \\
\hline 2.2.1 General Observations.............................. & 6 \\
\hline $\begin{array}{l}\text { 2.2.2 Observations I (Thresholds for Legal Oversize/Overweight Permits } \\
\text { Classification) } \ldots \ldots \ldots \ldots \ldots \ldots \ldots \ldots \ldots \ldots \ldots \ldots \ldots \ldots \ldots \ldots \ldots \ldots \ldots \ldots \ldots \ldots \ldots \ldots \ldots \ldots \ldots \ldots \ldots \ldots \ldots \ldots \ldots \ldots \ldots \ldots \ldots \ldots \ldots\end{array}$ & 9 \\
\hline 2.2.3 Observations II (Criteria for Fee Structures and Fee Levels) ................... & 12 \\
\hline 2.2.4 Observations III (Weight-Distance Fee Concept- The State of Practice)............ & 19 \\
\hline 2.2.5 Observations IV (Revenue Neutrality of Annual Permit Fee Structures)........... & 20 \\
\hline 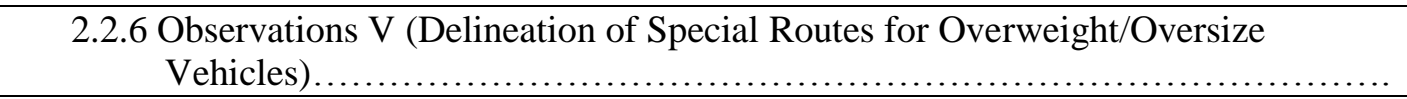 & 21 \\
\hline 2.3 Chapter Summary & 21 \\
\hline CHAPTER 3 COST IMPLICATIONS OF EXCESS TRUCK WEIGHTS & 22 \\
\hline 3.1 Literature Review of Pavement Damage Studies.................................... & 22 \\
\hline 3.2 Comparative analysis of Past Pavement Damage Studies................................ & 29 \\
\hline CHAPTER 4 REVENUE IMPLICATIONS OF EXCESS TRUCK WEIGHTS & 31 \\
\hline 4.1 Overall Discussion ........... & 31 \\
\hline CHAPTER 5 CASE STUDIES & 33 \\
\hline
\end{tabular}




\begin{tabular}{|c|c|}
\hline 5.1 Introduction... & 33 \\
\hline 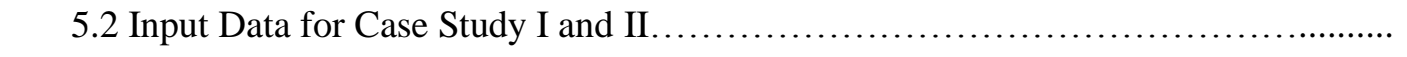 & 34 \\
\hline 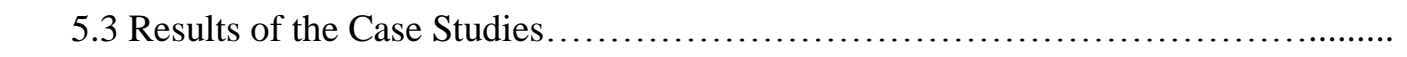 & 35 \\
\hline 5.3.1 Case Study I (Scenario I): Annual/Multiple Trip Permits......... & 35 \\
\hline 5.3.2 Case Study II (Scenario II): Single Trip Permits............................... & 37 \\
\hline 5.4 A Discussion of Issues Relating to the Case Studies I and II.. & 39 \\
\hline $\begin{array}{l}\text { 5.5 Case Study III: Calculation of Total Annual Amount to be Paid by Hypothetical } \\
\text { Company on the basis of Current Single-trip Fee Structure....................... }\end{array}$ & 41 \\
\hline $\begin{array}{l}\text { 5.6 Case Study IV - Determining Total Amount to be Paid by Hypothetical Trucker } \\
\text { Annually on the basis of Pavement Damage } \ldots \ldots \ldots \ldots \ldots \ldots \ldots \ldots \ldots \ldots \ldots \ldots \ldots \ldots \ldots \ldots \ldots \ldots \ldots \ldots \ldots\end{array}$ & 44 \\
\hline 5.6.1. Illustration of Calculations............................................ & 48 \\
\hline 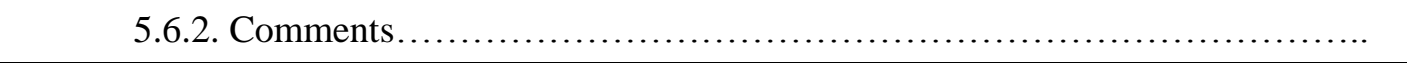 & 53 \\
\hline $\begin{aligned} & \text { CHAPTER } 6 \text { SUMMARY, CONCLUSIONS, AND DIRECTIONS FOR FUTURE } \\
& \text { RESEARCH }\end{aligned}$ & 54 \\
\hline 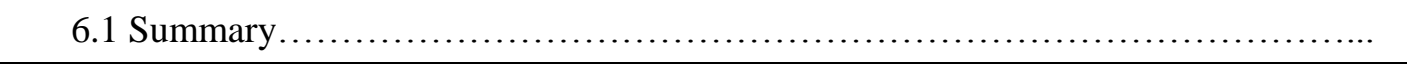 & 54 \\
\hline 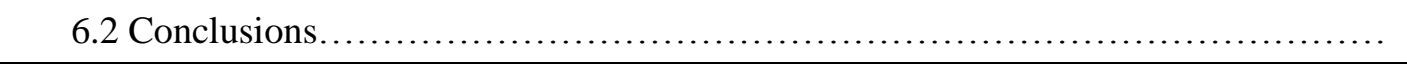 & 55 \\
\hline 6.3 Future Research... & 56 \\
\hline REFERENCES AND RESOURCES & 59 \\
\hline APPENDICES & 63 \\
\hline
\end{tabular}




\section{LIST OF TABLES}

\begin{tabular}{|c|c|c|}
\hline Table & & Page \\
\hline Table 2.1 & Single-Trip Permit Fees for Overweight/ Oversize Vehicle & 14 \\
\hline Table 2.2 & $\begin{array}{l}\text { Annual Permit Fees for States that Charge Fees based on Vehicle } \\
\text { Configuration (OS) and/or Vehicle Weight }(\mathrm{OW}) \ldots \ldots \ldots \ldots \ldots \ldots\end{array}$ & 16 \\
\hline Table 2.3 & 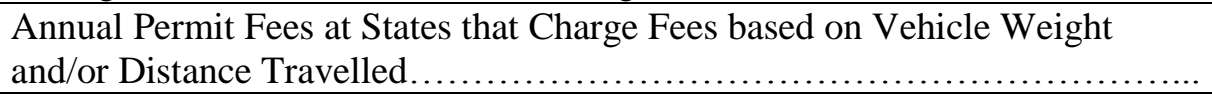 & 17 \\
\hline Table 2.4 & $\begin{array}{l}\text { Threshold for Extra-Legal Weights (above which a Permit is Required) }- \\
\text { (Annual Permits) } \ldots \ldots \ldots \ldots \ldots \ldots \ldots \ldots \ldots \ldots \ldots \ldots \ldots \ldots \ldots \ldots \ldots \ldots \ldots \ldots \ldots \ldots \ldots \ldots \ldots \ldots \ldots \ldots\end{array}$ & 18 \\
\hline Table 2.5 & 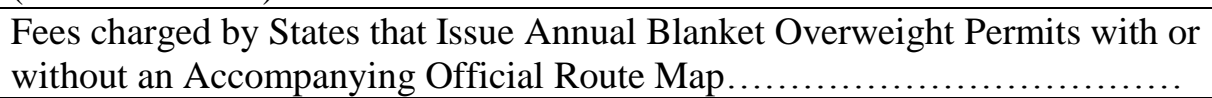 & 19 \\
\hline Table 2.6 & Single-Trip Permit Validity that each State Allows to OS/OW Permit Carrier. & 20 \\
\hline Table 3.1 & Marginal Pavement Maintenance Cost by Road Classification & 23 \\
\hline Table 3.2 & Marginal Pavement Maintenance Cost-New York & 23 \\
\hline Table 3.3 & Marginal Pavement Cost - Ontario, Canada & 25 \\
\hline Table 3.4 & Unit Pavement Damage Cost For Various Truck Types ( $\$ / 1000$ miles)...... & 26 \\
\hline Table 3.5 & Unit Pavement Damage Cost for Various Truck Types (\$/1000 Ton-miles).... & 26 \\
\hline Table 3.6 & 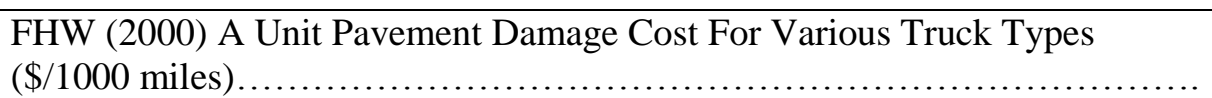 & 27 \\
\hline Table 3.7 & Comparison of Pavement Damage Cost............ & 29 \\
\hline Table 4.1 & $\begin{array}{l}\text { Yearly Revenue Streams from Extra-legal Truck Permits in Indiana, } 2002 \text { to } \\
2007 \text { (partial) } \ldots \ldots \ldots \ldots \ldots \ldots \ldots \ldots \ldots \ldots \ldots \ldots \ldots \ldots \ldots \ldots \ldots \ldots \ldots \ldots \ldots \ldots \ldots \ldots \ldots \ldots \ldots \ldots \ldots \ldots \ldots \ldots \ldots\end{array}$ & 26 \\
\hline Table 5.1 & Case Study Number of Trucks in Weight and Size Categories . & 35 \\
\hline Table 5.2 & Case Study Trucking Costs for INDIANA Operations - Annual Permit Basis.. & 35 \\
\hline Table 5.3 & Case Study Trucking Costs for ILLINOIS Operations - Annual Permit Basis.. & 36 \\
\hline Table 5.4 & 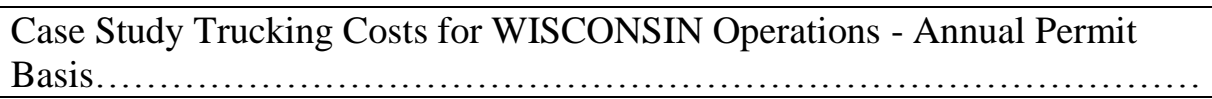 & 36 \\
\hline Table 5.5 & $\begin{array}{l}\text { Case Study Trucking Costs for IOWA and OHIO Operations }- \text { Annual Permit } \\
\text { Basis }\end{array}$ & 36 \\
\hline Table 5.6 & $\begin{array}{l}\text { Case Study Trucking Costs for MONTANA and MINNESOTA Operations }- \\
\text { Annual Permit Basis } \ldots \ldots \ldots \ldots \ldots \ldots \ldots \ldots \ldots \ldots \ldots \ldots \ldots \ldots \ldots \ldots \ldots \ldots \ldots\end{array}$ & 37 \\
\hline Table 5.7 & $\begin{array}{l}\text { Case Study Trucking Costs for MICHIGAN and KENTUCKY Operations - } \\
\text { Annual Permit Basis } \ldots \ldots \ldots \ldots \ldots \ldots \ldots \ldots \ldots \ldots \ldots \ldots \ldots \ldots \ldots \ldots \ldots \ldots \ldots \ldots \ldots \ldots \ldots \ldots \ldots \ldots \ldots \ldots \ldots \ldots \ldots \ldots \ldots\end{array}$ & 37 \\
\hline Table 5.8 & $\begin{array}{l}\text { Case Study Trucking Costs for INDIANA Operations }- \text { Single-trip Permit } \\
\text { Basis } \ldots \ldots \ldots \ldots \ldots \ldots \ldots\end{array}$ & 38 \\
\hline Table 5.9 & 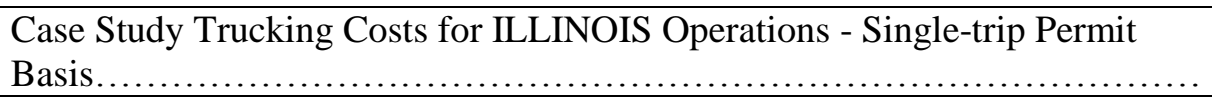 & 38 \\
\hline Table 5.10 & 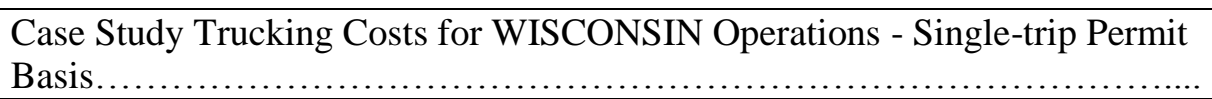 & 38 \\
\hline
\end{tabular}




\begin{tabular}{|c|c|c|}
\hline Table 5.11 & Case Study Trucking Costs for IOWA and OHIO Operations........ & 38 \\
\hline Table 5.12 & $\begin{array}{l}\text { Case Study Trucking Costs for MISSOURI Operations }- \text { Single-trip Permit } \\
\text { Basis } \ldots \ldots \ldots \ldots \ldots \ldots \ldots \ldots \ldots \ldots \ldots \ldots \ldots \ldots \ldots \ldots \ldots \ldots \ldots \ldots \ldots \ldots \ldots \ldots \ldots \ldots \ldots \ldots \ldots \ldots \ldots \ldots\end{array} \ldots$ & 39 \\
\hline Table 5.13 & $\begin{array}{l}\text { Case Study Trucking Costs for MINNESOTA, MICHIGAN and } \\
\text { KENTUCKY Operations - Single-trip Permit Basis................ }\end{array}$ & 39 \\
\hline Table 5.14 & Permit Fee Structure for Indiana State $\ldots \ldots \ldots \ldots \ldots \ldots \ldots \ldots$ & 42 \\
\hline Table 5.15 & $\begin{array}{l}\text { Single-Trip Permit Expenses vs. Truck-Miles Traveled for Various } \\
\text { Categories of OW Trucks } \ldots \ldots \ldots \ldots \ldots \ldots \ldots \ldots \ldots \ldots \ldots \ldots \ldots \ldots \ldots \ldots \ldots \ldots \ldots \ldots \ldots \ldots \ldots\end{array}$ & 44 \\
\hline Table 5.16 & FHWA (2000) Unit Pavement Cost For Various Truck Types ( $\$ / 1000$ miles).. & 45 \\
\hline Table 5.17 & $\begin{array}{l}\text { Weight per Axle vs. Unit Pavement Cost }(\$ / 1000 \text { miles }), \text { Urban and Rural } \\
\text { Interstates } \ldots \ldots \ldots \ldots \ldots \ldots \ldots \ldots \ldots \ldots \ldots \ldots \ldots \ldots \ldots \ldots \ldots \ldots \ldots \ldots \ldots \ldots \ldots \ldots \ldots \ldots \ldots \ldots \ldots \ldots \ldots \ldots \ldots \ldots \ldots \ldots \ldots \ldots\end{array}$ & 45 \\
\hline Table 5.18 & Unit Pavement Cost (\$/miles) for Trucks with GVW of $134,000 \mathrm{lbs} .$. & 46 \\
\hline Table 5.19 & $\begin{array}{l}\text { Unit Pavement Cost vs. Truck Miles Travelled for Urban and Rural } \\
\text { Interstates ( } 20 \text { to } 1,000 \text { Miles) }\end{array}$ & 47 \\
\hline Table 5.20 & $\begin{array}{l}\text { Unit Pavement Cost vs. Truck Miles Travelled for Urban and Rural } \\
\text { Interstates }(1,000 \text { to } 30,000 \text { Miles) }\end{array}$ & 47 \\
\hline
\end{tabular}




\section{LIST OF FIGURES}

\begin{tabular}{|c|c|c|}
\hline Figure & & Page \\
\hline Figure 2.1 & Differences in the General Schema for Truck Weight Permitting... & 8 \\
\hline Figure 2.2 & Upper-bound Threshold Weights by State.......... & 11 \\
\hline Figure 2.3 & Spatial Distribution of Upper Bound Thresholds across Midwest States........ & 11 \\
\hline Figure 2.4 & $\begin{array}{l}\text { States' Single-trip Permit Fee Categorized by Fee Attribute and by Truck } \\
\text { Attribute }\end{array}$ & 13 \\
\hline Figure 2.5 & $\begin{array}{l}\text { States' Annual Permit Fees Categorized by Fee Attribute and by Truck } \\
\text { Attribute } \ldots \ldots \ldots \ldots \ldots \ldots \ldots \ldots \ldots \ldots \ldots \ldots \ldots \ldots \ldots \ldots \ldots \ldots \ldots \ldots \ldots \ldots \ldots \ldots \ldots \ldots \ldots \ldots \ldots \ldots \ldots \ldots \ldots \ldots \ldots \ldots \ldots \ldots \ldots\end{array}$ & 13 \\
\hline Figure 3.1 & Marginal Pavement Cost as Function of ESAL & 25 \\
\hline Figure 3.1 & Unit Pavement Cost For Various Truck Types ( $\$ / 1000$ miles), Rural Roads..... & 28 \\
\hline Figure 3.2 & Unit Pavement Cost For Various Truck Types ( $\$ / 1000$ miles), Urban.............. & 28 \\
\hline Figure 4.1 & $\begin{array}{l}\text { Cumulative Monthly Revenue Streams from Extra-legal Truck Operations in } \\
\text { Indiana, Years } 2008 \text { and } 2009 \text { (partial) } \ldots \ldots \ldots \ldots \ldots \ldots \ldots \ldots \ldots \ldots \ldots \ldots \ldots \ldots \ldots \ldots \ldots \ldots \ldots \ldots \ldots \ldots \ldots\end{array}$ & 31 \\
\hline Figure 5.1 & Results of the Case Study I (Annual/Multiple-trip Permit Basis)................. & 37 \\
\hline Figure 5.2 & Results of the Case Study II (Single-trip Permit Basis)....................... & 39 \\
\hline Figure 5.3 & $\begin{array}{l}\text { Single-Trip Permit Expenses vs. Truck-Miles Traveled, for Various Truck OW } \\
\text { Categories } \ldots \ldots \ldots \ldots \ldots \ldots \ldots \ldots \ldots \ldots \ldots \ldots \ldots \ldots \ldots \ldots \ldots \ldots \ldots \ldots \ldots \ldots \ldots \ldots \ldots \ldots \ldots \ldots \ldots \ldots \ldots\end{array}$ & 43 \\
\hline Figure 5.4 & $\begin{array}{l}\text { Weight per Axle vs. Unit Pavement Cost, Urban and Rural Interstates } \\
\text { (developed using data from FHWA }(2000)) \ldots \ldots \ldots \ldots \ldots \ldots \ldots \ldots \ldots \ldots \ldots\end{array}$ & 46 \\
\hline Figure 5.5 & $\begin{array}{l}\text { Unit Pavement Cost vs. Truck Miles Travelled, Urban IS Highways (up to } \\
1000 \text { Miles) } \ldots \ldots \ldots \ldots \ldots \ldots \ldots \ldots \ldots \ldots \ldots \ldots \ldots \ldots \ldots \ldots \ldots \ldots \ldots \ldots \ldots \ldots \ldots \ldots \ldots \ldots \ldots \ldots \ldots\end{array}$ & 49 \\
\hline Figure 5.6 & $\begin{array}{l}\text { Unit Pavement Cost vs. Truck Miles Travelled, Urban IS Highways }(1,000 \text { to } \\
30,000 \text { Miles }) \ldots \ldots \ldots \ldots \ldots \ldots \ldots \ldots \ldots \ldots \ldots \ldots \ldots \ldots \ldots \ldots \ldots \ldots \ldots \ldots \ldots \ldots \ldots \ldots \ldots \ldots \ldots \ldots \ldots \ldots \ldots \ldots \ldots\end{array}$ & 49 \\
\hline Figure 5.7 & $\begin{array}{l}\text { Unit Pavement Cost vs. Truck Miles Travelled, Rural Interstate Highways (up } \\
\text { to } 1,000 \text { Miles) } \ldots \ldots \ldots \ldots \ldots \ldots \ldots \ldots \ldots \ldots \ldots \ldots \ldots \ldots \ldots \ldots \ldots \ldots \ldots \ldots \ldots \ldots \ldots \ldots \ldots \ldots \ldots \ldots \ldots \ldots \\
\end{array}$ & 50 \\
\hline Figure 5.8 & $\begin{array}{l}\text { Unit Pavement Cost vs. Truck Miles Travelled, Rural Interstate Highways } \\
(1,000 \text { to } 30,000 \text { Miles }) \ldots \ldots \ldots \ldots \ldots \ldots \ldots \ldots \ldots \ldots \ldots \ldots \ldots \ldots \ldots \ldots \ldots \ldots \ldots \ldots \ldots \ldots \ldots \ldots \ldots \ldots \ldots \ldots \ldots\end{array}$ & 50 \\
\hline Figure 5.9 & $\begin{array}{l}\text { Unit Pavement Cost vs. Number of Axles, Urban Interstate Highways (up to } \\
1,000 \text { iles) } \ldots \ldots \ldots \ldots \ldots \ldots \ldots \ldots \ldots \ldots \ldots \ldots \ldots \ldots \ldots \ldots \ldots \ldots \ldots \ldots \ldots \ldots \ldots \ldots \ldots \ldots \ldots \ldots \ldots \ldots \ldots \ldots \ldots\end{array}$ & 51 \\
\hline Figure 5.10 & 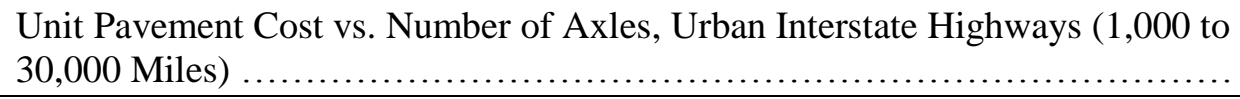 & 51 \\
\hline Figure 5.11 & $\begin{array}{l}\text { Unit Pavement Cost vs. Number of Axles, Rural Interstate Highways (up to } \\
1,000 \text { Miles) } \ldots \ldots \ldots \ldots \ldots \ldots \ldots \ldots \ldots \ldots \ldots \ldots \ldots \ldots \ldots \ldots \ldots \ldots \ldots \ldots \ldots \ldots \ldots \ldots \ldots \ldots \ldots \ldots \ldots \ldots \ldots \ldots \ldots \ldots \ldots \ldots\end{array}$ & 52 \\
\hline Figure 5.12 & $\begin{array}{l}\text { Unit Pavement Cost vs. Number of Axles, Rural Interstate Highways }(1,000 \text { to } \\
30,000 \text { Miles }) \ldots \ldots \ldots \ldots \ldots \ldots \ldots \ldots \ldots \ldots \ldots \ldots \ldots \ldots \ldots \ldots \ldots \ldots \ldots \ldots \ldots \ldots \ldots \ldots \ldots \ldots \ldots \ldots \ldots \ldots \ldots \ldots\end{array}$ & 52 \\
\hline
\end{tabular}




\section{CHAPTER 1: INTRODUCTION}

\subsection{Background Information}

Efficient and safe truck transportation is critical to a society in meeting its goals of economic competitiveness, social welfare, national defense, domestic security, emergency preparedness, and enhanced quality of life. In this respect, trucking continues to play an important role in the socioeconomic development of the state of Indiana. For purposes of safety and system preservation, trucking operational characteristics (speed, weights, widths, heights, etc.) are regulated using federal and state legislation and policies.

Under certain circumstances, special permits (also referred to in certain literature as "extralegal" permits) are granted to truck operators to allow them to exceed the specified operational restrictions. In this respect, the fiduciary responsibility borne by the Indiana Department of Transportation (INDOT) is dichotomous in nature: on one hand, the agency needs to adopt highway operations policies that retain and attract heavy industry including those that involve haulage of large loads, thereby enhancing economic development; on the other hand, the agency bears the responsibility to protect the billions of taxpayer dollars already invested in highway infrastructure and to adopt policies that do not lead to premature and accelerated deterioration of such assets through excess loading or undue safety hazard through oversize loads.

In Indiana, the Department of Revenue (INDOR), issues the special permits that allow the operation of overweight and oversize vehicles and collects the revenue from the issuance of these special permits. Approximately 270,000 permits are issued every year. According to personnel at Indiana's Motor Carrier Services Division (MCSD), INDOR retains only a relatively small portion of the collected OW/OS revenue and transfers most of it to INDOT. As is the case at other states, a critical task in Indiana is to ensure up-to-date and appropriate fee structures for these permits. Over the decades, various states have used a variety of approaches for establishing permit fee structures. These include: (i) determining allowable permit axle and/or axle groups weights using federal formula; (ii) developing a permit "design and analysis" vehicle and setting the allowable axle group weights based on the load effects of that vehicle, (iii) using developed methodologies to extrapolate the allowable permit weights from bridge design loading, (iv) using weight and dimension limitations that are based on expert opinion rather than analytical methods based solely on engineering concepts, (v) using basic fee structures or policies of adjacent states with modifications. 
The weight policies that were developed at the various states using these approaches have subsequently evolved over the years to accommodate local industry needs and the needs of specialized vehicles and industries. The dynamic nature of social and economic development trends translates into changing distributions and patterns of commercial vehicle movements. Furthermore, freight-intensive industries wishing to relocate from other states to Indiana or mulling a move to Indiana are likely to consider permit acquisition under the state's current single-trip permit structure for truck weights, as onerous, particularly when their operations involve a large number of vehicles and/or trips. For such industries, an annual trip permit would be far more convenient than daily, single-trip permits. However, the highway agency needs to ascertain that annual trip permitting, if adopted, will not lead to lower revenue. For at least one of these reasons, there often arises a need to review and update truck weight permitting practices at each state agency, to study the merits and demerits of alternative fee structures, and to assess the need for policy shifts in truck weight and size permitting.

Against this background, in July 2009, Mr. Leigh Morris, INDOT Deputy Commissioner, expressed the need to review the state of practice of truck weight permitting in Indiana and eight other states in the Midwest region. At the current time, there is an ongoing parallel research effort by the Indiana Department of Transportation Research Division that is developing quick assessment tools (based on structural impact analysis) for overweight truck permits in Indiana. It is expected that this present study will complement the efforts of that study.

\subsection{Study Objectives}

The objectives of this study have evolved from the original objective that was intended to review, document, and compare the state of practice on the permitting process for special truck weight and size in Indiana in relation to that at neighboring states, on the basis of the simplicity and ease of the permitting process for the permit applicant; convenience of the process (for the applicant) with respect to vehicle attributes, and the fee structure and basis for fees (per vehicle, per vehicle-mile, per ton-mile, etc.). In the course of carrying out this study, the researchers, at the request and/or approval of the SAC, went further to synthesize existing information on various issues related to the permit process including pavement cost damage due to excess loading, and the level (and past trends) of revenue generation in Indiana. Generally, the study is intended to generate information that ultimately can serve as a basis for INDOT to update/streamline its permitting process in the future. It is expected that by doing so, the state can be placed in a better position to monitor the impacts of 
overweight/oversize vehicles on highways, update its permit fee structures, and ultimately, preserve its investments in highway infrastructure without sacrificing the competitive position of the state.

\subsection{Contents of this Report}

This report discusses the state of truck permitting practice in Indiana and presents information on the practice at the neighboring states. This information was acquired from phone interviews and email contact with personnel responsible for truck weight and size permitting at the various state highway agencies, and agency websites maintained by the truck permit divisions of these agencies.

The first chapter of this report first provides a brief background to the study, including the study scope and objectives. Chapter 2 of the report presents the overweight/oversize truck permitting processes and criteria in Indiana and at Indiana's neighboring states: Michigan, Illinois, Ohio, Wisconsin, Iowa, Kentucky, Missouri, and Minnesota.

No study of overweight trucks is truly complete without a discussion of the damage caused by overweight loads on highway infrastructure. Such damage can be measured in terms of the cost of pavement repair that is needed due to such damage. Chapter 3 discusses the cost implications of excess truck weights. This is done for each road functional class, rural/area class, and truck class. The cost is expressed in dollars per miles of travel and per ton-miles of travel of each truck. The ton-mile refers to the payload only and excludes the dead weight.

Chapter 4 provides a brief discussion of the revenue streams from excess truck weight permitting in Indiana. This is done in order to provide a basis for preliminary assessment of whether the costs of damage by excess weight vehicles is commensurate with the revenue derived from excess weight permitting.

As seen in Chapter 2, the different permit fee structures at the different states make it difficult to undertake a really fair general comparison of permitting practices across the states. As such, Chapter 5 presents three case studies to facilitate such comparisons. The first case study assumes an annual permit while the second assumes single-trip permits. The third case study shows INDOT can evaluate alternative fee structures. This is done for a hypothetical annual number of trips and tripmiles on the basis of the current single-trip fee structure. The pavement damage incurred is also studied. Chapter 6 summarizes the report, offers some conclusions, and provides directions for future research. 


\section{CHAPTER 2: TRUCK PERMITTING - STATE OF PRACTICE}

\subsection{The State of Practice in Indiana}

As discussed in the Introduction to Chapter 1 of this report, Indiana's roads and highways were constructed to accommodate vehicles of certain attributes (dimensions and weights). For any vehicle whose attributes exceed those established by law, a permit is required. The permitting process also helps ensure that appropriate routes and bridges are used, and enforces the required safety procedures (MCSD-INDOR, 2009A). Also, the permit fee is a way to hold the extra-legal vehicle operators responsible, in a mostly aggregate fashion, for the damage caused by overweight vehicles to the highway bridges and pavements and also for the safety risks posed by oversize vehicles. By imposing such fees, not only is excessive use of overweight/oversize vehicles regulated but also revenue is generated to repair any damage caused by these vehicles and also to upgrade these infrastructure to standards that can better withstand and support such extra-legal operations. In this manner, the investments made in the highway infrastructure and the safety of Indiana motorists, are better safeguarded. Fees collected for the permits are distributed to the State Highway Fund which enables financing of state and local road improvements, maintenance and policing (MCSD-INDOR, 2009A).

An overweight vehicle is generally any vehicle whose overall weight exceeds 80,000 pounds. However, road and bridge stress levels are determined by the distribution of the weight, so it is also important that the weight per axle or sets of tandem axles (or in some cases, weight per tire) is also monitored. The total gross weight for a permit applicant is calculated using federal bridge formula and then compared with the established weight limits (see MCSD-INDOR (2009A)) for details of the federal formula and federal tables). The acronym OSW or OS/OW represents oversize and/or overweight vehicles. In extreme cases, permits may be sought for a "superload" (a load that exceeds certain threshold dimensions and/or threshold weight (in Indiana, the thresholds are $15 \mathrm{ft}$ height, $16 \mathrm{ft}$ width, and $110 \mathrm{ft}$ length; and 120,000 lbs, respectively), or a load that fails the overload analysis. In seeking a permit for a vehicle that violates the given levels, the applicant first confirms that their load is not divisible. Definition of nondivisible loads are stated in 23 Code of Federal Regulations 658.5 (MCSD, 2009A). There is one exception to the rule of nondivisible loads: for the Indiana-designated "extra heavy-duty highways" in northern Indiana, applicants may haul divisible loads with a total gross weight of up to 134,000 pounds, subject to legal axle weights with a special permit commonly known as a "Michigan Train Permit". In Indiana, weights between 80,000 lbs and 120, 000 lbs are simply described as "overweight"; those over 120,000 lbs are considered as superloads (ref: Indiana Oversize and Overweight Permitting Hand Book Pages 10 and 11). 
Permits for oversize or overweight vehicles are provided through the consolidated efforts of the Indiana Department of Transportation and the Indiana Department of Revenue. The Department of Transportation maintains and safeguards Indiana highways and evaluates particular road conditions and passability. Permits are issued after it has been ascertained that road traffic will not be severely affected and the highway and bridges will not be seriously damaged. The Department of Revenue ensures that the proper permits are issued and the fees paid. In Indiana, there are a number of exemptions from oversize/overweight permits (see Appendix 1). The lists of permit types and fees are provided in Appendix 2.

In Indiana, options for obtaining a permit are the Internet, permitting service, fax, mail, and walk in. Details for each option are provided in Appendix 2. For trucking organizations new to Indiana, the permit applicant visits the Motor Carrier Services page of the Indiana Department of Revenue website to set up an OSW account by clicking the link: "New to Indiana? Apply for an OSW Account". The applicant enters basic information, account information, USDOT numbers, and address and contact information. For pre-approval, INDOR has in place a process that facilitates the process of superload permit approvals for the benefit of applicants who face time constraints. Indiana's current permitting system allows the applicant to have the INDOT engineering analysis done ahead of time, well before the time that the permit is needed, and the applicant receives a superload pre-approval number. With this pre-approval number, the applicant (for the next 30 days) can obtain the trip permits using the same vehicle configuration and route without any additional INDOT analysis or delays. "Superload" permits are issued if the load exceeds the threshold dimensions (15 ft height, $16 \mathrm{ft}$ width, and $110 \mathrm{ft}$ length) and/or weight threshold (120,000 lbs).

Any load that fails the overload analysis or is over 200,000 lbs is reviewed by an INDOT engineer, and this typically requires additional processing time. Appendix $2 \mathrm{~B}$ presents INDOR's form M-233ST which lists the allowable weights and axle characteristics for a special-weight single-trip application. Also, the 22 extra heavy duty highway routes are listed on the form.

\subsection{Comparison of the Practice in Indiana and at Neighboring States}

The results of the internet search and phone interviews showed that in the state of Indiana, permitting processes for trucking operations are same as or superior to most other states in terms of the ease and convenience of permit acquisition.

With regard to fee amounts and structures across the states, tables and charts were prepared to compare the special (or, extra-legal) vehicle permitting practices of eight Midwest states on the basis of the fee structure and basis of the actual fee amounts (per vehicle, per vehicle-mile, per ton-mile, 
etc.). These states are: Michigan, Illinois, Ohio, Wisconsin, Iowa, Kentucky, Missouri, and Minnesota. A brief summary of the data obtained is presented herein in narrative form. This section includes general observations on the permitting processes, thresholds for legal oversize/overweight permits classification, criteria for fee structures and fee levels, the state of practice of the weightdistance fee concept for extra-legal weights and sizes, revenue neutrality of annual permit fee structures, and the practice of delineating special routes for extra-legal vehicles. To complement these discussions, Tables 2.1 to 2.7 provide more detailed, quantitative information categorized by permitting criteria and by state.

\subsubsection{General Observations}

The findings from the internet search and phone interviews show that there is a great deal of variability in the truck permitting practices at various states (see Tables 2.1 and 2.2). This finding is similar to those made by Humphrey (1998) who investigated uniformities in oversize/overweight permits (published ten years ago as NCHRP Synthesis of Practice 143). The findings are also consistent with those of Moffett and Whitford (1994). Very few states in the present study were found to have identical permitting practices, even though some general patterns seem to emerge across some states.

With regard to legal size and weights, it was seen that the permitting States have generally uniform thresholds are established by federal legislation: the existing legal Federal maximum GVW (cap) limit for the Interstate System is $80,000 \mathrm{lbs}$ (although some States allow truck combination weights above this cap under Federal grandfathering provisions). This federal cap is what we herein refer to as "upper threshold for legal weights". Gross vehicle weights that exceed this cap are generally termed "excess loads", "superloads", or "extremely overweight". These are rather loose terms and their exact meanings vary from state to state. For example, the term "superload" may refer to weights that exceed $80,000 \mathrm{lbs}$ at certain states, 90,000 lbs at other states, or even 100,000 lbs or more at yet others. For example, in Indiana, "superloads" refers to weights exceeding 120,000 lbs. Across the states, thus, there are significantly different upper limits (upper thresholds) for what the state classifies as "excess loads", "superloads", or "extremely overweight or oversize trucks". For the purpose of clarification, we herein present Figure 2.1 which illustrates the different general schema for weight permitting across the states on the basis of threshold criteria. Before we proceed to discuss the different schema, it is useful to discuss the different types of thresholds that define the schema. 


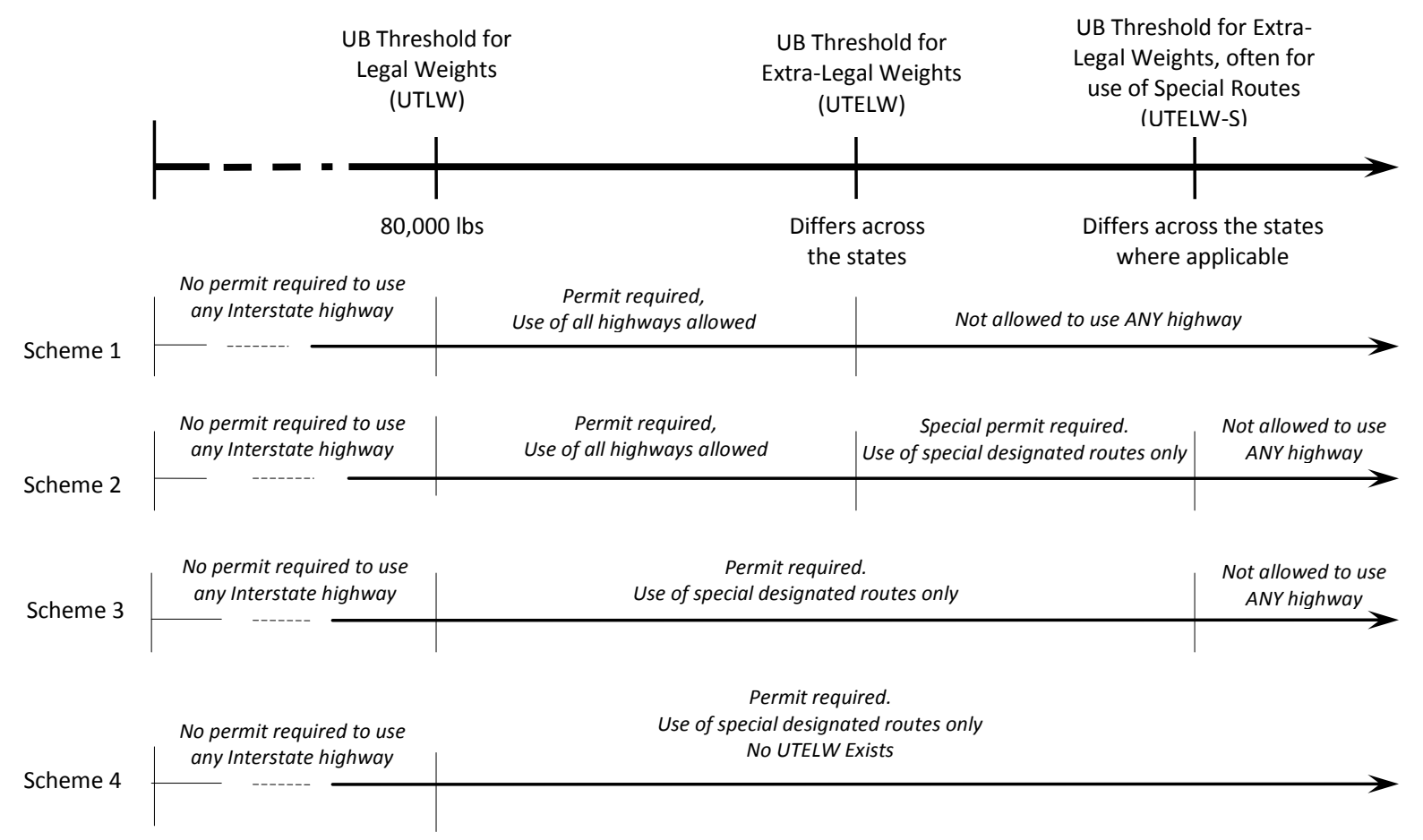

Figure 2.1 Differences in the General Schema for Permitting (Truck Gross Weights)

[Note: Variations in this diagram may exist for axle-based weights; truck dimensions; permit type (single/multiple/annual), or net weights]

Upper Threshold for Legal Weights (UTLW): As discussed, this is the federally-mandated limit of $80,000 \mathrm{lbs}$. Beyond this threshold, the truck weight is termed extra-legal and a special permit is required before the vehicle can use the highway.

Upper Threshold for Extra-Legal Weights (UTELW): For extra-legal trucks (i.e., trucks whose weights exceed the federally-mandated limit of 80,000 lbs), there may exist an upper limit (UTELW) that restricts their operations on the highway network. In the state of Wisconsin, for example, a truck seeking multiple-trip permits cannot exceed a weight of 170,000 lbs. In certain states, the UTELW threshold may be applicable only to certain permitting structures; for example, in a particular state there could exist separate UTELWs for single-trip permits, multiple-trip permits, and annual blanket permits.

Upper Threshold for Extra-Legal Weights for use of Special Routes (UTELW-S): As discussed in the previous section, some states may have a UTELW that forbids the operations of extra-legal trucks on all highways in a state. Where the restriction is for only certain highway segments or functional classes, the threshold may be designated UTELW-S. Often, these road segments or functional classes 
are those that were built to relatively high engineering standards with or without the anticipation of extra heavy truck operations.

Having explained the different possible weight thresholds that may exist in a state's weight permitting policy structure, we now proceed to describe the different policy schema that are based on these thresholds in the different states. While these schema are herein shown for gross weight thresholds, there could also exist similar schema for axle-based weights. For example, a truck could have weight less than $80,000 \mathrm{lbs}$ but still be considered overweight if one of its axles weigh over $20,000 \mathrm{lbs}$. In that case, the upper threshold axle weight is 20,000 lbs. Also, in a given state, there could be different schema for different permit types (single/multiple/annual) due to different thresholds for such trip types and the highway classes or routes where they are permitted.

\section{Schema 1}

In Schema 1, there exists (as in other schema), an upper threshold for legal weights (as established by the federal government at $80,000 \mathrm{lbs}$ ). Then there could be another threshold for extra-legal truck weights, UTELW, (for example, 170,000 lbs for multiple-trip permits in Wisconsin). According to this schema, trucks with weights between these two thresholds are allowed to operate with an overweight permit at any highway in the state while those exceeding the upper threshold for extralegal weights are not allowed to use any highway in the state under any circumstances. This is the simplest of all the schema.

\section{Schema 2}

In Schema 2, similar to Schema 1, there is an upper threshold for legal weights of 80,000 lbs. Then, as in Schema 1, there is an upper threshold for extra-legal trucks and trucks with weights falling between these thresholds are allowed to operate on all highways with a permit. Unlike Schema 1, however, there is a third weight threshold, UTELW-S, above which trucks may only use specific highway classes, such as Interstates, or specially-designated highway segments. Often, these routes have very high standards of pavement design to accommodate these excessive loads. For example, in the state of Indiana, there exist routes designated as "extra heavy-duty highways" mostly in the northern part of the state, where divisible loads may be hauled with a total gross weight of up to 134,000 pounds, subject to legal axle weights. Truck weights exceeding UTELW-S are prohibited from operating at any highway in the state.

\section{Schema 3}

Schema 3 is identical to Schema 2 with the exception that only designated routes can be used for extra-legal trucks (that is those with weights exceeding $80,000 \mathrm{lbs}$. 


\section{Schema 4}

In Schema 4, which is the most liberal of all the schema, the only restriction is the 80,000 lbs for legal operations. Extra-legal operations (weights exceeding 80,000 lbs), regardless of weight are allowed as long as the trucker pays the appropriate fee.

Another general observation from the data is that while most Midwest states have both permitting structures (fee per single trip as well as an annual blanket fee), there is a great deal of variability in the fee structure details and fee levels across the states. Certain states that have any one of these two fee structures also have an additional charge imposed per distance of travel or per weight-distance (implicitly) of travel. As has been shown in past literature, truckers who typically make many trips per year will find it more economical to use the annual fee option. However, results of data analysis in previous studies show that the annual fee option does not seem to be favorable to the state highway agency from the perspective of revenue generation (Moffett and Whitford, 1994). This is also shown in the case studies presented in Chapter 5 of this report. It is therefore not surprising that several state agencies that switched from single-trip to annual permit fee structures in the eighties and nineties had taken great pains to ensure that the annual fee structures, as much as possible, were revenue-neutral. As the Texas experience shows, their efforts do not seem to have been very successful (TTI, 1988).

\subsubsection{Observations I (Thresholds for Legal Oversize/Overweight Permit Classification)}

Following up from the general observations in the previous section, permits for extra-legal operations, specifically, oversize/overweight (OS/OW) trucks are generally required when truck characteristics exceeds the legal thresholds of size or weight. With regard to weight for example, an upper threshold for legal weights UTLW (Figure 2.1) may be defined as the limit above which trucking operations need a permit - 80,000 lbs (Gross Vehicle Weight) for Interstate highways. Unlike the case for gross vehicle weights, the upper thresholds for axle weight (for overweight classification) and for vehicle dimensions (for oversize classification) were found to vary significantly across the states. In Indiana, for example, the maximum weight per axle is 20,000 lbs, and the upper bound threshold legal dimensions, UTLD, are: 8'6" width and 40'length for a single vehicle; and 60' length and 13'6" height for a two-vehicle combination (MCSD-INDOR, 2009A)

The upper threshold for legal weights is the point after which extra heavy weights, or extralegal operations, may be permitted, albeit for a fee. However, there often exists a limit to which the state can tolerate extra-legal weights. As such, a second threshold is established (shown in Figure 2.1 
as "Threshold for Extra-Legal Weights". At certain states, loads that lie between the upper thresholds for legal weights (UTLW) and that for extra-legal weights (UTELW) are referred to as "superloads".

For the third category of weights that exceed even this threshold for extra-legal weights, certain states prohibit trucking operations or allow them only under very special permits and/or only at specific highway classes or specially-designed road segments, as schematically illustrated in Figure 2.1. But even where it is allowed under such circumstances, there again may exist a limit, UTELW-S, beyond which trucking operations are prohibited. These two upper thresholds, UTELW and UTELW$\mathrm{S}$, vary considerably across the states.

At certain states, there is no clear demarcation of the thresholds; instead, the permit fee increases in a certain proportion with higher levels of overweight exceeding the federal legal weight.

It is not certain how the upper thresholds were established the various states - it may very well be that they were set up using expert judgments that considered either the design loads or the load bearing capacity of existing pavements and bridges in that state, or both. It is expected that for Indiana, an ongoing parallel study by INDOT's Research Division will address this issue.

Figures 2.2 and 2.3, developed using the annual/routine/multiple permit fees data in Tables 2.1 to 2.6, presents an approximate picture of the distribution of upper bound weight thresholds for extra-legal trucking operations, UTELW, across the Midwest states. In certain states, the number of axles (or implicitly, the weight per axle) is also considered when the maximum loading thresholds are being established: in Illinois, for example, the threshold of 120,000 lbs indicated in the figure pertains to trucks with 6 or more axles (see Appendix 4C for further details). The figure seems to suggest that generally speaking, Wisconsin and Indiana have the highest threshold for extra-legal truck weights (170,000 lbs and, over 200,000 lbs, respectively), followed closely by Missouri (160,000 lbs), and Iowa (156,000 lbs); the next tier comprises Michigan (150,000 lbs) and Minnesota (145,000 lbs) and then Ohio, Kentucky, Illinois (120,000 lbs). However, it must be noted that (i) some states implicitly or explicitly prohibit highway operations for trucks that exceed this upper threshold; other states allow more load provided a permit is issued for that load, (ii) these thresholds are for permitting structures that differ across the states: some are for routine purposes, others are for annual blanket permits; a complete comparison across states therefore must be done carefully and on a case-by-case basis (iii) the order of weight thresholds are shown in the figure is not necessarily the case when the axle-based threshold (instead of gross weight thresholds) is the criteria for the comparison. In this study, lack of data on axle-weight thresholds precluded a comparison of such thresholds across the states. Secondly, for such comparison there exist several other criteria besides weight thresholds, some of these criteria include fees and trucker perspectives. For example, Wisconsin may have a high 
upper threshold (which is viewed favorably by truckers) but a high fee for overweight trucks (which is viewed unfavorably by truckers). Thus, a comprehensive assessment of the comparative favorableness of permitting policies across the states can only be made when all the other contexts are duly considered. In Chapter 5 of this report, we present case studies that help even the playing field for a more holistic assessment of these practices across the states.

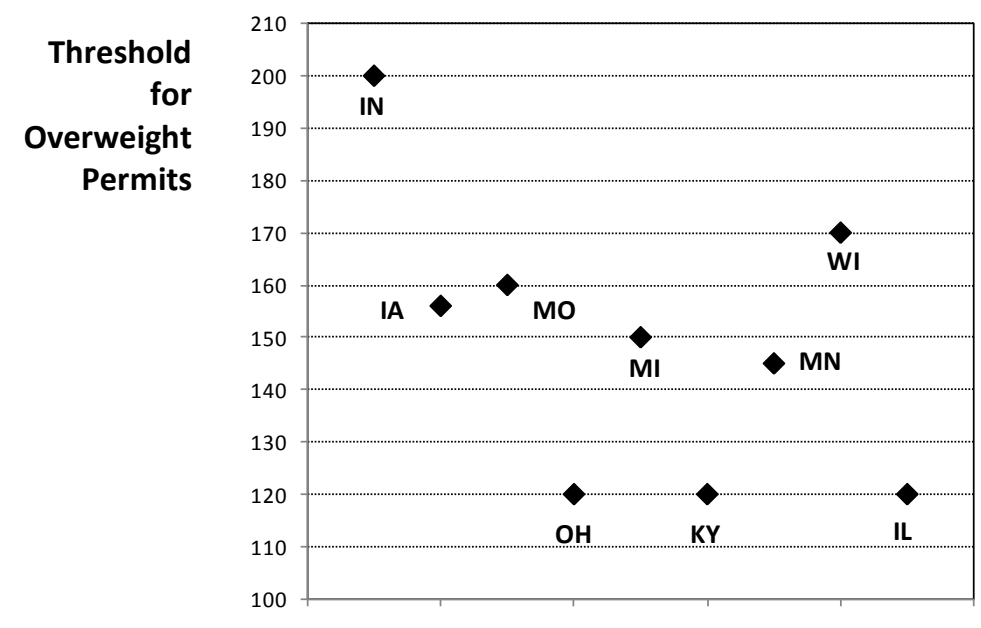

Note: Certain states, such as Indiana allow weights above these thresholds but duly impose penalties (e.g., extra fees) for weights exceeding them. See Table 2.4

Figure 2.2 Upper Thresholds for Regular Overweight Permits

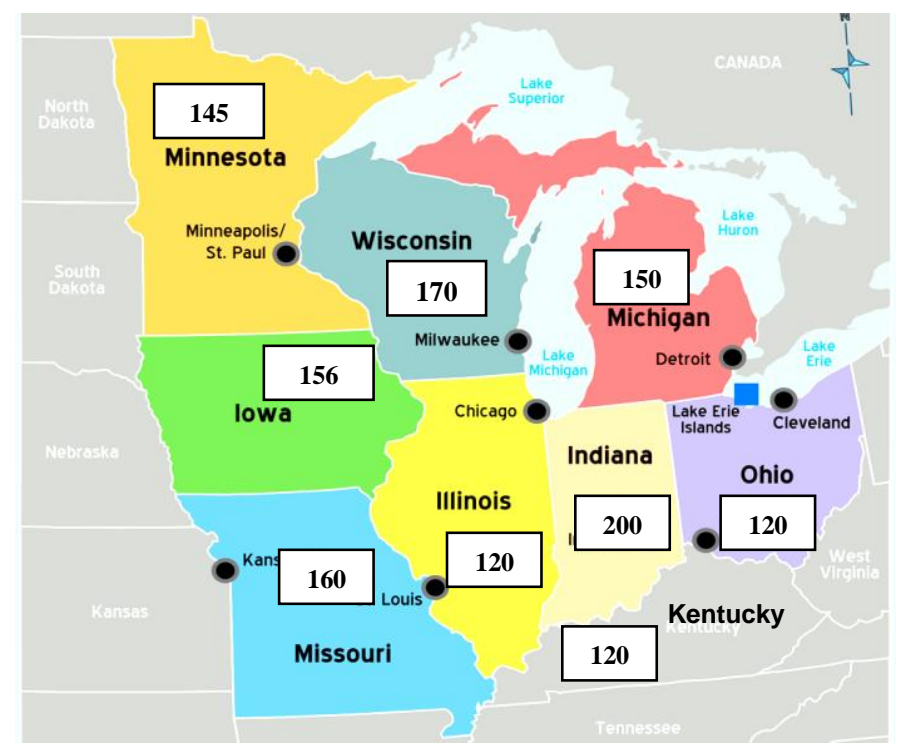

Note: For certain states, this refers to the maximum weights for which a "Superload" Permit is issued).

Certain states, such as Indiana, allow weights above these thresholds but duly impose corresponding penalties, See Table 2.4

Figure 2.3 Upper Thresholds for Regular Overweight Permits 


\subsubsection{Observations II (Criteria for Fee Structures and Fee Levels)}

In this section, we discuss our observations on the fee amounts (levels) and the criteria for establishing these amounts, at each of the eight states in the Midwest region of the United States.

Figures 2.4 and 2.5 present the states' single-trip permit fee and annual permit fees, respectively, categorized by fee attribute (that is, flat fee only, distance-based fee (\$/mile), or both flat fee and distance-based) and also by truck attribute (overweight only, oversize only, or both overweight and oversize). Further details are provided in Tables 2.1 and 2.2.

Table 2.1 presents the single-trip overweight/oversize permit fees for those states that charge fees on the basis of vehicle dimension or configuration (OS fees) or vehicle weight (OW fees) or both. It is seen that most of the states in the study area make available opportunities for truckers to pay fees per single trip. For this, the following states were found to have the simplest fee structures flat fees that are irrespective of weight or distance traveled: Iowa $\$ 10$ per trip; Kentucky $\$ 60$ per trip; and Missouri $\$ 15$ per trip for oversize-only trucks and \$50 per trip for trucks that are both oversize and overweight. In some other states such as Wisconsin, the per-trip fee structure is not so simple mostly because it is elaborately designed to ensure equity: the per-trip fees (with or without a flat base per-trip fee) are charged for overweight and/or oversize vehicles depending on the extents by which their excess weights, heights, widths and/or lengths exceed the legal limits or depending on the distance they travel.

Table 2.2, similar to Figure 2.4, presents the annual permit fees for those states that change fees on the basis of vehicle configuration (OS) and/or vehicle weight (OW). Table 2.3, similar to Figure 2.5, presents the annual permit fees at states that charge fees based on vehicle weight and/or

distance travelled. These tables show that most of the states in the study area have also established annual permits for these vehicles. This reflects a change in the state of practice since 1994 when only a handful of states had annual permits (Whitford and Moffett, 1994). Again, similar to the case for single-trip permits, it is seen that at some of these states, the annual permit fees (with or without a flat base permit fee) are charged for oversized vehicles depending on the excessiveness of their heights, widths or lengths (or any two of these size attributes). At other states, annual permit fees (with or without a flat base fee) are charged for overweight vehicles depending on the excessiveness of their weights. Furthermore, as seen in Table 2.3, some states charge annual permit fees for overweight or oversize trucks depending on the distance they travel. Table 2.4 presents the upper thresholds for extra-legal weights, specifically, what is known as the "superload permits" at some states. It must be noted that some states implicitly or explicitly prohibit highway operations for trucks that exceed this 
upper threshold; other states allow more load provided a permit is issued for that load. For example, Indiana allows as much as 200,000 lbs or more but imposes additional fees for such weights.

\begin{tabular}{|c|c|c|c|}
\hline $\begin{array}{l}\text { Both flat-fee } \\
\text { and distance }\end{array}$ & $\begin{array}{l}\left.\text { IN }{ }^{1}: 20+\$ 0.35 \text { per mile (up to } 108,000 \mathrm{lbs}\right) \\
* 20+0.60 \text { per mile }(108001 \mathrm{lbs} \text { to } 150,000 \mathrm{lbs}) \\
* * 20+1.00 \text { per mile (over } 150,000 \mathrm{lbs}) \\
{ }^{4} \mathrm{MO}=\$ 15+\$ 20 \text { per each } 10 \text { kips }>80 \mathrm{kips}+\$ 425 \text { to } \\
\$ 925 \text { based on distance traveled }\end{array}$ & & $\begin{array}{l}\mathrm{IN}=\text { Greater of Oversize or } \\
\text { Over weight Fee }{ }^{1}\end{array}$ \\
\hline Distance- & & $\begin{array}{l}\mathrm{IL}^{2}=\$ 12 \text { to } \$ 125 \\
\text { (Depending upon truck } \\
\text { size and miles }\end{array}$ & $\begin{array}{l}\mathrm{IL}^{2}=\$ 10 \text { to } \$ 295 ; \text { (Depending upon truck } \\
\text { size, } \mathrm{nr} \text {. of axles and miles travelled) }\end{array}$ \\
\hline $\begin{array}{r}\text { Flat-fee } \\
\text { Only }\end{array}$ & $\begin{array}{l}\mathrm{IA}=\$ 10 \\
\mathrm{KY}=\$ 60 \\
\mathrm{MI}=\$ 50 \\
\mathrm{MO}=\$ 15+\$ 20 \text { per each } 10 \mathrm{kips}>80 \\
\text { kips up to } 160 \mathrm{kips}\end{array}$ & $\begin{array}{l}\mathrm{IN}^{1}=\$ 20 \text { to } \$ 40 \\
\mathrm{IA}=\$ 10 \\
\mathrm{KY}=\$ 60 \\
\mathrm{OH}=\$ 65-\$ 100 \\
{ }^{5} \mathrm{MO}=\$ 15 \\
\mathrm{MI}=\$ 15 \\
{ }^{3} \mathrm{WI}=\$ 15 \text { to } \$ 25\end{array}$ & $\begin{array}{l}{ }^{6} \mathrm{OH}=\$ 135 \text { to } \$ 200 \\
\mathrm{MI}=\$ 50, \mathrm{IA}=\$ 10 \\
\mathrm{KY}=\$ 60 \\
\mathrm{MN}=\$ 15+\text { Pavement Damage Fee } \\
\text { based on “X number of moves" }\end{array}$ \\
\hline & $\begin{array}{c}\text { Truck is } \\
\text { Overweight Only }\end{array}$ & $\begin{array}{c}\text { Truck is } \\
\text { Oversize Only }\end{array}$ & $\begin{array}{c}\text { Truck is Both Overweight } \\
\text { \& Oversize }\end{array}$ \\
\hline $\begin{array}{l}{ }^{1} \text { See Ap } \\
{ }^{2} \text { Add; }+ \\
\text { Note: } P I \\
{ }^{3} \text { Add } \$ \\
\text { and/or } \\
{ }^{4} \text { For ver } \\
{ }^{5} \text { Add } \$ 2 \\
{ }^{6} \text { Additio } \\
{ }^{*} \text { Vehic } \\
{ }^{* *} \text { Vehic }\end{array}$ & $\begin{array}{l}\text { ndix } 2-\text { List of IN Permits and Fees. } \\
0 \text { district fee }+\$ 1 \text { online transmission fee, See } \\
\text { se see Appendices } 1 \text { through } 4(A \text { to } K) \text { for furt } \\
\text { District fee }+\$ 10 \text { Bridge Fee+ } \$ 1 \text { online perm } \\
\text { 70kips GVW } \\
\text { les over } 160 \text { kips GVW } \\
\text { movement feasibility fee for vehicles }>16 \text { ' wi } \\
\text { I fees for vehicles over } 120 \text { kips based on form } \\
\text { over } 120,000 \text { lbs charged } \$ 10 \text { executive fee. } \\
\text { sover } 200,000 \text { lbs charged } \$ 10 \text { executive fee }\end{array}$ & $\begin{array}{l}\text { pendix } 4 B \text { and } 4 C \text { for } \\
\text { rdetails about Fee/ pe } \\
\text { rder fee }+\$ 10 \text { pavem } \\
>16^{\prime} \text { high, or } 150^{\prime} \text { lon } \\
\text { base rate }+0.04 \times[(G \\
25 \text { design and review }\end{array}$ & $\begin{array}{l}\text { details on IL fee structure. } \\
\text { class. } \\
\text { amage fee for vehicles }>16^{\prime} \text { width } \\
120,000) / 2000)] \\
\text { bridges fees at } \$ 10 \text { per bridge. }\end{array}$ \\
\hline
\end{tabular}

Figure 2.4 Single-trip Permit Fees Categorized by Fee Attribute and Truck Attribute

\begin{tabular}{|c|c|c|c|}
\hline $\begin{array}{l}\text { Both flat-fee and } \\
\text { distance based }\end{array}$ & - & - & - \\
\hline $\begin{array}{r}\text { Distance-based } \\
\text { only }\end{array}$ & - & - & - \\
\hline $\begin{array}{r}\text { Flat-fee } \\
\text { Only }\end{array}$ & $\begin{array}{l}\mathrm{MO}=\$ 300 \text { to } \$ 624 \\
\mathrm{MI}=\$ 100 \\
\mathrm{MN}=\$ 60 \text { to } \$ 850 \\
\mathrm{WI}=\$ 65 \text { to } \$ 1050 \\
\mathrm{OH}=\$ 500 \text { to } \$ 2970 \\
\mathrm{IL}^{2}=\$ 10 \text { to } \$ 295\end{array}$ & $\begin{array}{l}I^{1}=\$ 405, \quad W I=\$ 30-\$ 90 \\
M O=\$ 128 \text { to } \$ 400 \\
M I=\$ 45, \quad L^{2}=\$ 100 \text { to } \$ 150 \\
K Y=\$ 80 \text { to } \$ 500 \\
M N=\$ 24 \text { to } \$ 120 \\
O H=\$ 250 \text { to } \$ 1170\end{array}$ & $\begin{array}{l}I A=\$ 25 \text { to } \$ 300 ; M I=\$ 100 \\
M N=\$ 60 \text { to } \$ 850 \\
K Y=\$ 20 \text { to } \$ 500 \\
I^{2}=\$ 10 \text { to } \$ 295 \\
O H=\$ 500 \text { to } \$ 2970\end{array}$ \\
\hline & $\begin{array}{c}\text { Truck is } \\
\text { Overweight Only }\end{array}$ & $\begin{array}{c}\text { Truck is } \\
\text { Oversize Only }\end{array}$ & $\begin{array}{c}\text { Truck is Both Overweight } \\
\text { \& Oversize }\end{array}$ \\
\hline $\begin{array}{l}{ }^{1} \text { See Appe } \\
{ }^{2} \text { Add; }+\$ 4 \\
{ }^{3} \text { OS Only: } \\
\text { Note: Plec }\end{array}$ & $\begin{array}{l}\text { ix } 2-\text { List of IN Permits } \\
\text { listrict fee }+\$ 1 \text { online trc } \\
+\$ 30 \text { (renewal/extensi } \\
\text { see Appendices } 1 \text { throu }\end{array}$ & $\begin{array}{l}\text { fee, See Appendix } 4 B \text { an } \\
45 \text {, OW: } \$ 50+\$ 100 \text { (re } \\
\text { for more details about }\end{array}$ & $\begin{array}{l}\text { ore details on IL fee structure. } \\
\text { ension fee) = } \$ 150 \\
\text { it class. }\end{array}$ \\
\hline
\end{tabular}

Figure 2.5 Annual/Multiple Trip Permit Fee Categorized by Fee Attribute and Truck Attribute 
Table 2.1 Single Trip Overweight/ Oversize Permit Fees

(a) Comparison based on Vehicle Configuration (OS) and/or Vehicle Weight (OW)

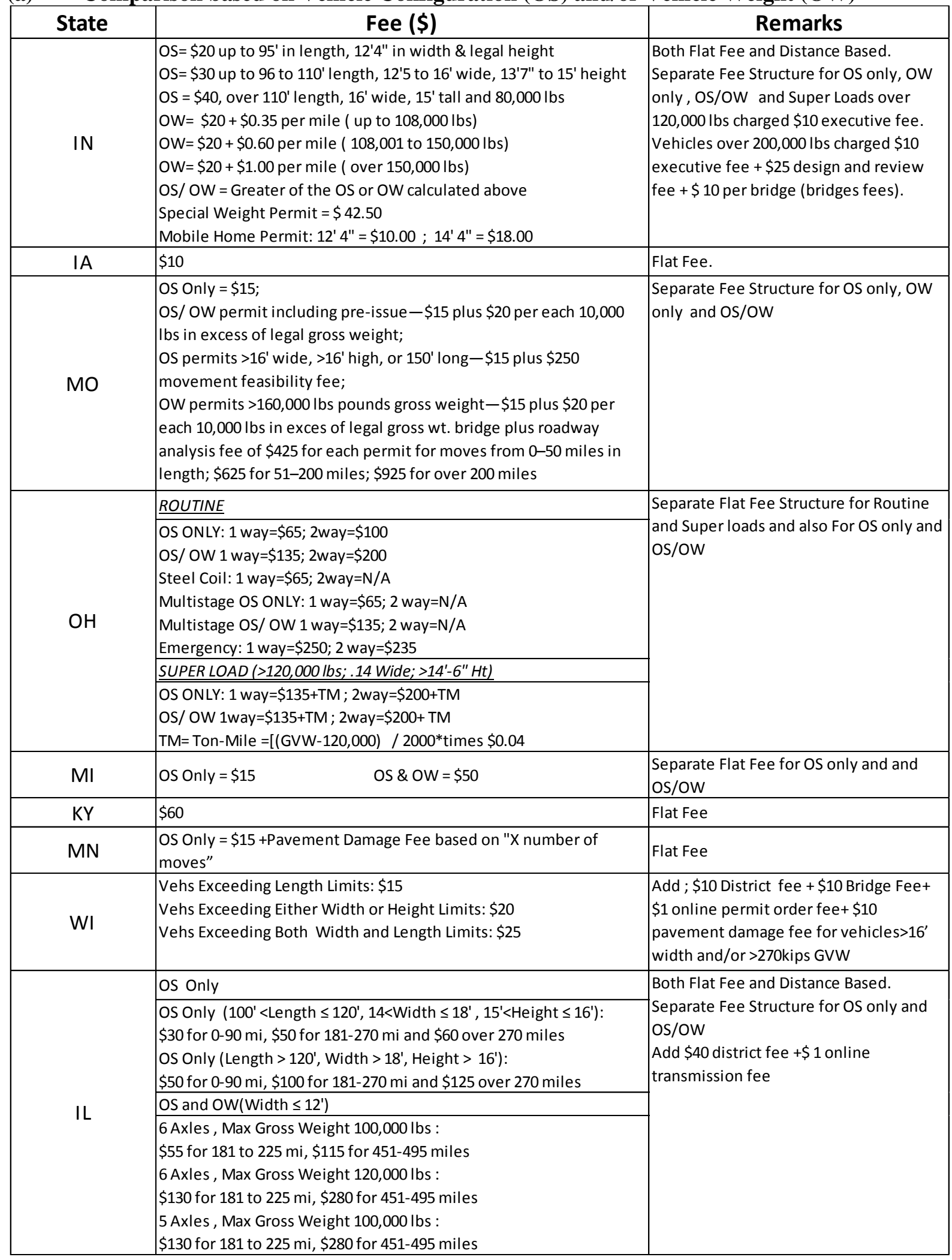




\section{(b) Comparison based on Fee Type: Flat Fee vs. Flat+Distance Based Fee}

\begin{tabular}{|c|c|c|c|}
\hline & Flat Fee Only & Distance Based & Both Flat and Distance Based \\
\hline IN & $\begin{array}{l}\text { OS=\$20 up to } 95^{\prime} \text { in length, } 12^{\prime} 4 " \text { in width } \\
\& \text { legal height } \\
\text { OS= } \$ 30 \text { up to } 96 \text { to } 110^{\prime} \text { length, } 12^{\prime} 5 \text { to } 16^{\prime} \\
\text { wide, } 13^{\prime} 7^{\prime \prime} \text { to " } 15^{\prime} \text { tall } \\
\text { OS }=\$ 40 \text {, over } 110^{\prime} \text { length, } 16^{\prime} \text { wide, } 15^{\prime} \\
\text { tall and } 80,000 \text { lbs }\end{array}$ & & $\begin{array}{l}O W=\$ 20+\$ 0.35 \text { per mile (upto } 108,000 \mathrm{lbs}) \\
O W=\$ 20+\$ 0.60 \text { per mile }(108,001 \text { to } 150,000 \mathrm{lbs}) \\
O W=\$ 20+\$ 1.00 \text { per mile over } 150,000 \mathrm{lbs})\end{array}$ \\
\hline IA & $\$ 10$ & & \\
\hline MO & & & $\begin{array}{l}\text { Fees for vehicles over } 160 \text { kips: } \$ 15+\$ 20 \text { per ea. } \\
10,000 \text { lbs in excess of legal gross weight plus } \\
\text { bridge and roadway analysis fee of } \$ 425 \text { for ea. } \\
\text { permit for moves from 0-50 miles in length; } \$ 625 \\
\text { for 51-200 miles; } \$ 925 \text { for over } 200 \text { miles }\end{array}$ \\
\hline \multirow{4}{*}{$\mathrm{OH}$} & ROUTINE & & SUPER LOAD \\
\hline & $\begin{array}{l}\text { OS ONLY: } 1 \text { way=\$65; } 2 \text { way=\$100 } \\
\text { OS/ OW } 1 \text { way=\$135; } 2 \text { way=\$200 } \\
\text { Steel Coil: } 1 \text { way=\$65; } 2 \text { way=N/A } \\
\text { Multistage OS ONLY: } 1 \text { way=\$65; } \\
\text { 2way=N/A } \\
\text { Multistage OS/ OW } 1 \text { way=\$135; } \\
\text { 2way=N/A } \\
\text { Emergency: } 1 \text { way=\$250; } 2 \text { way=\$235 }\end{array}$ & & $\begin{array}{l}\text { OS } / \text { OW } 1 \text { way }=\$ 135+T M ; 2 \text { way }=\$ 200+T M \\
T M=\text { Ton-Mile }=[(G V W-120,000) / 2000 * \$ 0.04\end{array}$ \\
\hline & $\begin{array}{l}\text { SUPER LOAD }\left(>120,000 \mathrm{lbs} ; .14 \text { Wide; }>14^{\prime}-\right. \\
\left.6^{\prime \prime} \mathrm{Ht}\right)\end{array}$ & & \\
\hline & OS ONLY: 1way $=\$ 135+T M ; 2$ way $=\$ 200$ & & \\
\hline MI & $\begin{array}{c}\text { OS Only }=\$ 15 \\
\text { OS \& OW }=\$ 50\end{array}$ & & \\
\hline KY & $\$ 60$ & & \\
\hline MN & OS Only $=\$ 15$ & & \\
\hline WI & $\begin{array}{l}\text { Vehs Exceeding Length Limits: \$15 } \\
\text { Vehs Exceeding Either Width or Hieght } \\
\text { Limits: } \$ 20 \text { Vehs Exceeding Both Width } \\
\text { and Length Limits: } \$ 25\end{array}$ & & \\
\hline IL & & $\begin{array}{l}\text { OS Only }\left(100{ }^{\prime}<\text { Length } \leq 120^{\prime}, 14<\text { Width } \leq 18^{\prime}, 15^{\prime}<\text { Height } \leq 16^{\prime}\right) \text { : } \\
\$ 30 \text { for } 0-90 \mathrm{mi}, \$ 50 \text { for } 181-270 \mathrm{mi} \text { and } \$ 60 \text { over } 270 \mathrm{mi} \\
\left.\text { OS Only (Length }>120^{\prime}, \text { Width }>18^{\prime} \text {, Height }>16^{\prime}\right) \text { : } \\
\$ 50 \text { for } 0-90 \mathrm{mi}, \$ 100 \text { for } 181-270 \mathrm{mi} \text { and } \$ 125 \text { over } 270 \mathrm{mi} \\
\left.\text { OS and OW(Width } \leq 12^{\prime}\right) \\
6 \text { Axles, Max Gross Weight } 100,000 \mathrm{lbs}: \\
\$ 55 \text { for } 181 \text { to } 225 \mathrm{mi}, \$ 115 \text { for } 451-495 \mathrm{mi} \\
6 \text { Axles, Max Gross Weight } 120,000 \mathrm{lbs}: \\
\$ 130 \text { for } 181 \text { to } 225 \mathrm{mi}, \$ 280 \text { for } 451-495 \mathrm{mi} \\
5 \text { Axles, Max Gross Weight } 100,000 \text { lbs : } \\
\$ 130 \text { for } 181 \text { to } 225 \mathrm{mi}, \$ 280 \text { for } 451-495 \mathrm{mi}\end{array}$ & \\
\hline
\end{tabular}


Table 2.2 Annual/Multiple Trip/Routine Permit Fees for States that Charge Fees based on Vehicle Configuration (OS) and/or Vehicle Weight (OW)

\begin{tabular}{|c|c|c|}
\hline State & Fee (\$) & Remarks \\
\hline IN & \$405 (OS Only) & $\begin{array}{l}\text { Flat Fee } \\
\text { Continuing Annual ( } 365 \text { days) }\end{array}$ \\
\hline IA & $\$ 300$ (OS/OW) & Flat Fee \\
\hline MO & $\begin{array}{l}\text { Single commodity: } \$ 128 \text { (OS Only) } \\
\text { Multiple commodity: } \$ 400 \text { (OS Only) }\end{array}$ & $\begin{array}{l}\text { Flat Fee } \\
\text { Annual Blanket ( } 365 \text { days) }\end{array}$ \\
\hline $\mathrm{OH}$ & $\begin{array}{l}\text { Continuing Annual Permit } \\
\text { OS Only: } \$ 970 \text { (1 way), } \$ 1170 \text { (Return) } \\
\text { OS/OW: } \$ 1970 \text { (1 way), } \$ 2970 \text { (Return) } \\
\text { Steel Coil: } 1 \text { way = \$470; } 2 \text { way = N/A } \\
\text { Michigan Legal: } 1 \text { way = } \$ 470 ; 2 \text { way = } \$ 470 \\
\text { Annual Blanket Permit } \\
\text { Boat: } 1 \text { way=\$100; } \\
\text { Farm Equipment: } 1 \text { way = \$100; } \\
\text { Construction Equipment: } 1 \text { way = } \$ 100 ; \\
\text { Manufactured Building: } 1 \text { way = } \$ 100 ; \\
\text { Marina: } 1 \text { way = } \$ 100 ;\end{array}$ & Flat Fee \\
\hline MI & $\begin{array}{l}\text { OS Only: } 15+\$ 30(\text { renewal fee })=\$ 45 \\
\text { OW: } \$ 50+\$ 100(\text { renewal fee })=\$ 150\end{array}$ & $\begin{array}{l}\text { Flat Fee } \\
\text { Annual Extended }\end{array}$ \\
\hline KY & $\begin{array}{l}\text { Non-divisible-less than } 14 \mathrm{ft} \text {. wide: } \$ 250 \\
\text { Non-divisible-14 ft. to } 16 \mathrm{ft} \text {. wide: } \$ 500 \\
\text { Farm-less than } 14 \mathrm{ft} \text {. wide: } \$ 80 \\
\text { Farm-14 ft. to } 16 \mathrm{ft} \text {. wide: } \$ 150 \\
\text { Industrial Haul: } \$ 20\end{array}$ & $\begin{array}{l}\text { Flat Fee } \\
\text { Steel load }=\$ 250 \text { (limited to } 35 \text { miles) }\end{array}$ \\
\hline $\mathrm{MN}$ & $\begin{array}{l}\text { Construction Supplies: } \$ 120 \text { (OS Only ) } \\
\text { Construction Supplies: \$200 (OS \& OW Up to 90M lbs GVW) } \\
\text { Farm machinery: } \$ 120 \text { (OS Only) } \\
\text { Farm machinery: } \$ 200 \text { (OS \& OW Up to 90M lbs GVW) }\end{array}$ & Flat Fee \\
\hline WI & $\begin{array}{l}\text { OS Only } \\
12 \text { Month: } \$ 60 \text { (over length only), } \$ 90 \text { (over length/over width/ } \\
\text { over height) } \\
\text { OW and/or OW \& OS } \\
12 \text { Month : } \$ 1050 \text { up to } 170 \text { kips GVW }\end{array}$ & $\begin{array}{l}\text { Flat Fee } \\
\text { Multiple Permit ( from } 3 \text { months to } 12 \\
\text { months period) }\end{array}$ \\
\hline IL & $\begin{array}{l}\text { Permits for Limited Continuous Operation (Oversize construction } \\
\text { equipment or vehicles) } \\
\$ 100 \text { for OS Only ( Length } \leq 70^{\prime} \text {, Width } \leq 10^{\prime} \text { Height } \leq 14^{\prime} 6^{\prime \prime} \text { ) } \\
\$ 150 \text { for OS Only (Length } \leq 85^{\prime} \text {, Width } \leq 12^{\prime} \text {, Height } \leq 14^{\prime} 6^{\prime \prime} \text { ) }\end{array}$ & $\begin{array}{l}\text { Flat Fee } \\
\text { Repeated Moves } \\
\text { Add } \$ 40 \text { district fee }+\$ 1 \text { online } \\
\text { transmission fee }\end{array}$ \\
\hline
\end{tabular}


Table 2.3 Annual/Multiple Trip/Routine Permit Fees for States that Charge Fees based on Vehicle Weight and/or Distance Travelled

\begin{tabular}{|c|c|c|}
\hline State & Fee (\$) & Remarks \\
\hline IA & $\$ 300$ (OS/OW) & OS or OW considered but distance not considered \\
\hline Mo & $\begin{array}{l}\text { Emergency OW permit (round trip): } \$ 624 \\
\text { OW well drillers or concrete pump truck permit: } \$ 300\end{array}$ & Annual Blanket Permit Distance not considered \\
\hline $\mathrm{OH}$ & $\begin{array}{l}\text { Contuing Annual Permit } \\
\text { OS/OW: } \$ 1970 \text { (1 way), } \$ 2970 \text { (Return); } \\
\text { Annual Blanket Permit } \\
\text { Boat: } 1 \text { way=\$100; } \\
\text { Farm Equipment: } 1 \text { way=\$100; } \\
\text { Construction Equipment: } 1 \text { way=\$100; } \\
\text { Manufactured Building: } 1 \text { way=\$100; } \\
\text { Marina: } 1 \text { way=\$100; }\end{array}$ & Annual Blanket Permit Distance not considered \\
\hline MI & OW: $\$ 50+\$ 100$ (renewal fee) $=\$ 150$ & Annual Extended; Distance not considered \\
\hline KY & $\begin{array}{l}\text { Steel. } 35 \text { mile limit: } \$ 250 \\
\text { Steel-statewide } \$ 500 \\
\text { Industrial Haul: } \$ 20\end{array}$ & \\
\hline MN & $\begin{array}{l}\text { Agriculture/6 Axle up to } 90,000 \text { lbs GVW: } \$ 300 \\
\text { Agriculture/7 Axle up to } 97,000 \text { lbs GVW: } \$ 500 \\
\text { Construction Supplies: } \$ 200 \text { (OS \& OW Up to } 90 M \text { Ibs GVW) } \\
\text { Farm machinery: } \$ 200 \text { (OS \& OW Up to } 90 \mathrm{M} \text { lbs GVW) }\end{array}$ & Distance not considered \\
\hline WI & $\begin{array}{l}\text { OW and/or OW \& OS } \\
12 \text { Month : \$1050 up to } 170 \text { kips GVW }\end{array}$ & Distance not considered \\
\hline IL & $\begin{array}{l}\text { OS and OW (Width } \leq 12 ') \\
6 \text { Axles, Max Gross Weight } 100,000 \mathrm{lbs} \text { : } \\
\$ 55 \text { for } 181 \text { to } 225 \mathrm{mi}, \$ 115 \text { for } 451-495 \mathrm{mi} \\
6 \text { Axles, Max Gross Weight } 120,000 \mathrm{lbs}: \\
\$ 130 \text { for } 181 \text { to } 225 \mathrm{mi}, \$ 280 \text { for } 451-495 \mathrm{mi} \\
5 \text { Axles, Max Gross Weight } 100,000 \mathrm{lbs}: \\
\$ 130 \text { for } 181 \text { to } 225 \mathrm{mi}, \$ 280 \text { for } 451-495 \mathrm{mi}\end{array}$ & $\begin{array}{l}\text { Single trip Permit that lasts for } 5 \text { Days } \\
\text { Add } \$ 15 \text { for width }>12^{\prime} \\
\text { Add } \$ 40 \text { district fee }+\$ 1 \text { online transmission fee } \\
\text { Other combinations of weight and distance are } \\
\text { also available at } \\
\text { http://www.dot.state.il.us/road/infoforms.html }\end{array}$ \\
\hline
\end{tabular}


Table 2.4 Upper Thresholds for Extra-Legal Weights (Superload Permits)

\begin{tabular}{|c|c|c|}
\hline State & GVW & Remarks \\
\hline IN & $120,000 \mathrm{lbs}$ & $\begin{array}{l}\text { For single-trip permit only. } \\
\text { Vehicles over } 120,000 \mathrm{lbs} \text { are allowed but are charged } \$ 10 \text { executive fee. } \\
\text { Vehicles over } 200,000 \mathrm{lbs} \text { are allowed but are charged } \$ 10 \text { executive fee }+ \\
\$ 25 \text { design and review fee }+ \text { bridges fees at the rate of } \$ 10.00 \text { per bridge. }\end{array}$ \\
\hline IA & $156,000 \mathrm{lbs}$ & Single-trip and annual permits \\
\hline MO & $160,000 \mathrm{lbs}$ & $\begin{array}{l}\text { For single-trip permit only. } \\
\text { Fees for vehicles over } 160 \text { kips: } \$ 15+\$ 20 \text { per ea. } 10,000 \text { lbs in excess of } \\
\text { legal gross weight plus bridge and roadway analysis fee of } \$ 425 \text { for ea. } \\
\text { permit for moves from } 0-50 \text { miles distance; } \$ 625 \text { for } 51-200 \text { miles; } \\
\$ 925 \text { for over } 200 \text { miles }\end{array}$ \\
\hline $\mathrm{OH}$ & $120,000 \mathrm{lbs}$ & $\begin{array}{l}\text { Additional fees for vehicles over } 120 \text { kips based on formula : base rate }+ \\
0.04 \times((G V W-120,000) / 2000))\end{array}$ \\
\hline MI & $150,000 \mathrm{lbs}$ & Only for extended permits for construction equipments \\
\hline KY & Not Specified & \\
\hline $\mathrm{MN}$ & $145,000 \mathrm{lbs}$ & For multiple-trip permit only \\
\hline WI & $170,000 \mathrm{lbs}$ & $\begin{array}{l}\text { For multiple-trip and annual permits only. } \\
\text { For single-trip permits, vehicles over } 150,000 \text { lbs are charged } \$ 85+\$ 10 \\
\text { executive fee for each } 10,000 \text { lbs in excess }\end{array}$ \\
\hline IL & $120,000 \mathrm{lbs}$ & $\begin{array}{l}\text { For routine permits. Only for vehicles with } 6 \text { or more axles. } \\
\text { Lower thresholds for vehicles with } 5 \text { or fewer axles. } \\
\text { Upper bound threshold for superload permit: } 187 \text { kips }\end{array}$ \\
\hline
\end{tabular}


Table 2.5 Fees Charged by States that Issue Annual Blanket Overweight Permits with or without an Accompanying Official Route Map

\begin{tabular}{|c|c|c|}
\hline State & Fee (\$) & Remarks \\
\hline $\mathrm{OH}$ & $\begin{array}{l}\text { Boat: } 1 \text { way = \$100; } 2 \text { way }=\text { N/A } \\
\text { Farm Equipment: } 1 \text { way = \$100; } 2 \text { way }=\text { N/A } \\
\text { Construction Equipment: } 1 \text { way }=\$ 100 ; 2 \text { way = N/A } \\
\text { Manufactured Building: } 1 \text { way = } \$ 100 ; 2 \text { way = N/A } \\
\text { Marina: } 1 \text { way = \$100; } 2 \text { way = N/A }\end{array}$ & $\begin{array}{l}\text { Accompanying official route } \\
\text { map required }\end{array}$ \\
\hline MO & $\begin{array}{l}\text { Emergency OW permit (round trip): } \$ 624 \\
\text { OS permit (single commodity): } \$ 128 \\
\text { OS permit (multiple commodity): } \$ 400 \\
\text { OW well drillers or concrete pump truck permit: } \$ 300 \\
\text { Thirty (30)-day blanket permit: } \$ 300\end{array}$ & $\begin{array}{l}\text { Accompanying official route } \\
\text { map not required }\end{array}$ \\
\hline
\end{tabular}

Table 2.6 Single-Trip Permit Validity that each State Allows to OS/OW Permit Carrier

\begin{tabular}{|c|l|}
\hline State & \multicolumn{1}{|c|}{ Validity } \\
\hline IN & $\begin{array}{l}\text { OS= } 1 \text { trip in 15 days; OW=1 trip in 15 days; } \\
\text { OS/ OW = 1 trip in 15 days; } \\
\text { Mobile Home Permit: } 12^{\prime} 4^{\prime \prime}=1 \text { trip in 15 days; } \\
14^{\prime} 4^{\prime \prime}=1 \text { trip in 5 days }\end{array}$ \\
\hline IA & 1 trip in 5 days \\
\hline OH & $\begin{array}{l}1 \text { trip in 5 days. Thereafter, extension/ revision can be made with extra fee of \$10 and } \\
\text { \$50 for routine and super loads, respectively. }\end{array}$ \\
\hline MO & 1 trip in 7 days \\
\hline MI & 1 trip in 5 days \\
\hline KY & 10 Days \\
\hline WI & 1 trip in 14 Days \\
\hline IL & 1 trip in 5 days \\
\hline
\end{tabular}

\subsubsection{Observations III (Weight-Distance Fee Concept- The State of Practice)}

On the basis of our findings, it seems that with the exception of Illinois, and to some extent, Indiana and Ohio, no Midwest state has adopted explicitly the weight-distance concept as a basis for the permit fee structure for its overweight or oversize trucks. It is noteworthy to mention that the state of Oregon (outside the Midwest region) is the most well-known leader in implementing this policy explicitly for all commercial vehicles (overweight and oversize trucks included) and in monitoring compliance. In general, the trucking industry has voiced opposition to weight-distance taxation. However, as reported by Moffett and Whitford in 1994, trucking companies that deal regularly with overweight trucks were significantly less opposed to weight-distance taxation compared to those who regularly deal with legal weight trucks. It is not certain whether these stakeholders hold such perspectives at the current time. 
As indicated in the preceding paragraph, the practice of weight-distance fees has existed at some states even if only implicitly. As seen in Table 2.1, at certain states (Indiana, Ohio, and Illinois), the fees charged for overweight vehicles is different for different weight groups and distances traveled: for a given weight group, a higher fee is charged for a greater distance; and for a given distance, a higher fee is charged for a greater weight. Clearly, at these states, the overweight fee structure shows significant resemblance to the weight-distance concept of permitting practiced in Oregon. This probably explains the 1994 Moffett and Whitford observation (that companies that deal regularly with overweight trucks were significantly less opposed to weight-distance taxation): for such truck operators, such taxation schemes are similar to the status quo of their fee paying structures because weight-distance taxation yields a form of permit fee structure that is similar to the fee structure to which they are accustomed.

\subsubsection{Observations IV (Revenue Neutrality of Annual Permit Fee Structures)}

In the late eighties and early nineties, a number of highway agencies switched from single-trip permit systems to annual blanket flat fee permit systems. It is reported that while these agencies benefited from enhanced convenience (and possibly, monitoring cost savings) due to reduced monitoring efforts of the single trips, they lost significant revenue overall because commercial vehicle operators had no limit to the number of trips they made in one year on an annual permit (Moffett and Whitford,1994). It was also pointed out that many trucking companies consolidated their overweight operations from many vehicles that on occasion would obtain a single-trip overweight permit, to a few vehicles with annual overweight permits that were dedicated to handle as many of a company's overweight movements as possible in order to maximize the investment made in permit purchases. Clearly, such practices were favorable to the truckers but unfavorable to the revenue generation efforts of the highway agencies, particularly considering that overweight trucks cause added wear and tear, and that the maintenance of further deteriorated infrastructures requires additional funding. Findings from the Moffett and Whitford survey of commercial vehicle operators showed that officials in states having annual permits complained that their state could not adequately deal with added road and bridge damage done by overweight trucks, a sentiment that was echoed by a subsequent Texas study.

As such, highway agencies interested in annual permitting sought (and still seek) to establish fee levels that are "revenue neutral" in other words, fee levels that would not jeopardize the amounts of revenue generated in comparison to the single-trip permit systems. However, in the case of annual permits, maintaining revenue neutrality in an agency's fee structure may require significant and regular monitoring of the overweight truck movements (number of trips, weights, and distance 
traveled) so that the permit fee amounts can be updated as and when necessary. Therefore, there may be a proclivity towards (or for agencies that had switched to annual permitting, nostalgia for) singletrip permit structures, particularly for highway agencies unwilling or unable to undertake the extra monitoring efforts to ensure revenue neutrality.

\subsubsection{Observations V (Delineation of Special Routes for Overweight/Oversize Vehicles)}

In the highway network of any state, there are roads built to superior standards of pavement design (materials and thicknesses), bridge strength, and geometry (lane widths, curve radii, slopes, etc.) and also there are others built to relatively inferior standards. For overweight and oversize vehicles, the use of the lower class roads would be deleterious to the physical structures as well as the safety of other road users and thus need to be routed to operate only at those highways that can support their excessive weights and/or can accommodate their unconventional dimensions. In this respect, many states have developed maps that identify the routes that should be used by overweight vehicles of certain weights and axle spacing. These specified routes could be an entire system of roads (such as interstates) or specific road sections. In Figure 2.1, we present different permitting schema that incorporate the conditions under which extra-legal trucks are allowed to use certain specified highways (or sections thereof) because of the relatively high design and geometric standards of those highways. Also Appendix 2B presents a list of the roads in Indiana for which overweight trips are allowed and single-trip permits are issued.

\subsection{Chapter Summary}

This chapter presented tables and charts that synthesize data collected from eight Midwest states to compare their practices and policies for special vehicle permitting practices. This was done on the basis of the fee structure and basis of the actual fee amounts (per vehicle, per vehicle-mile, per tonmile, etc.). The chapter also discussed general observations on the permitting processes, thresholds for legal oversize/overweight permits classification, criteria for fee structures and fee levels, state of practice of the weight-distance fee concept for extra-legal weights and sizes, revenue neutrality of annual permit fee structures, and the practice of delineating special routes for extra-legal vehicles. This chapter lays a foundation for making a case for a more holistic comparative assessment of the permitting practices across the states. In the two subsequent chapters, we examine the cost and revenue implications of the practice of excess weight permitting. 


\section{CHAPTER 3: COST IMPLICATIONS OF EXCESS TRUCK WEIGHTS}

\subsection{Literature Review of Pavement Damage Studies}

There is no question that overweight trucks cause accelerated damage to a highway pavement either directly or together with environmental factors such as rain and freeze-thaw transitions. On a system-wide context, there are several issues relating to the cost of infrastructure damage by overweight vehicles and the relationship between this cost and the revenue generated by overweight permits. There appears to have been no research specifically for overweight permitting cost implications at the Midwestern states. However, a number of studies have been carried out in the United States and abroad to quantify the pavement damage inflicted by heavy vehicles in general. We herein present information from a few of these studies.

The Texas Transportation Institute (TTI) investigated the relationship between pavement damage from truck loading and the revenues that were generated for pavement repair. It is worthy to note that the Texas study found that the revenue generated from the permitting of overweight vehicles in Texas has been inadequate to recover the estimated cost of deterioration of the highway system caused by these vehicles. The TTI estimated the dollar amount of damage to the state highway system caused by overweight vehicles at $\$ 62.8$ million dollars per year (TTI, 1988). However, in fiscal year 1990 , only $\$ 2.8$ million was collected in fees for all the overweight permits and that this amount covered only the program's administrative costs.

Small, Winston and Evans (1989) used data from AASHTO Road Test and other empirical data to examine the relationship between pavement life and number of axle load repetitions to failure. Re-estimated equations suggested a third power (rather than a fourth power) relationship between axle weight and pavement damage. Age and climate were seen to affect pavements through their interaction with axle weight rather independently. The study concluded that the climate does not have an independent effect but renders pavements more vulnerable to damage by heavy vehicles. Small et al. (1989) found that pavement damage cost (\$ per ESAL-mile) varied between 1.48 to 125.45 cents (in \$US 1985) at the existing investment levels (practice being followed by agency); under optimal investment levels the pavement damage cost (\$ per ESAL-mile) was found to vary between 0.33 to 101.30 cents (in \$US 1985) for different road functional classes. The cents per ESAL-mile charges for a 5-axle, semi-trailer with $80,000 \mathrm{lbs}$ gross weight on local or Interstate roads, can be estimated from this table. 
Table 3.1 Marginal Pavement Maintenance Cost by Road Classification

(Small at al., 1989)

\begin{tabular}{lcc}
\hline Road Functional Class & \multicolumn{1}{c}{ Marginal Maintenance Cost Cents per ESAL-mile (in \$US 1985) } \\
\cline { 2 - 3 } & Current Investment (1985) & Optimal Investment (1985) \\
\hline Rural Interstate & 1.48 & 0.46 \\
\hline Rural Principal Arterial & 4.38 & 1.13 \\
\hline Minor Arterial & 10.02 & 2.60 \\
\hline Major Collector & 16.49 & 9.96 \\
\hline Minor Collector & 31.18 & 16.09 \\
\hline Local & 101.30 & 101.30 \\
\hline Urban Interstate & 2.38 & 0.33 \\
\hline Urban Freeway & 4.32 & 0.61 \\
\hline Urban Principal Arterial & 10.92 & 0.87 \\
\hline Minor Arterial & 33.92 & 3.23 \\
\hline Collector & 125.45 & 13.66 \\
\hline Local & 40.92 & 40.92 \\
\hline
\end{tabular}

Vitaliano and Held (1990) estimated the cost of pavement damage by heavy vehicles using data from New York State (Table 3.2). This study used an analytical approach similar to that of Small et al. (1989) and assumed that $50 \%$ pavement deterioration is caused by vehicles and $50 \%$ by climate (an assumption based on work done by Paterson (1987)). As we show in subsequent parts of this chapter, this load/climate split is not necessary equal. The study found that road damage cost varies across different road classes. The road damage cost was explicitly calculated for a 5-axle, semi-trailer with 80,000 lbs gross weight.

Table 3.2 Marginal Pavement Maintenance Cost of New York Roads

(Vitaliano and Held, 1990)

\begin{tabular}{lcc}
\hline \multirow{2}{*}{ Road Functional Class } & \multicolumn{2}{c}{ Pavement damage cost (\$ US 1990) } \\
\cline { 2 - 3 } & $\begin{array}{c}\text { Cents per mile for } \mathbf{8 0 , 0 0 0 ~ l b} \\
\text { 5-axle tractor-trailer }\end{array}$ & $\begin{array}{c}\text { Cents per ESAL-mile for 80,000 lb } \\
\text { 5-axle tractor-trailer }\end{array}$ \\
\hline Rural and Urban Interstate & 0.030 & 0.6 \\
\hline Urban Expressway & 0.069 & 1.4 \\
\hline Rural Expressway & 0.064 & 1.3 \\
\hline Urban Arterial & 0.138 & 2.8 \\
\hline Rural Minor Arterial & 0.106 & 2.1 \\
\hline Urban Minor & 0.387 & 14.8 \\
\hline Arterial/Collector & & 7.7 \\
\hline Rural Collector & 0.742 & \\
\hline
\end{tabular}


In Canada, Nix et al. (1992) developed pavement damage cost estimates based on typical construction costs in southern Ontario. Using data from that state, the study concluded that road damage cost varies for roads with different traffic volumes. The pavement damage cost ranged from 0.4 cents per ESAL-Mile for low-volume roads to 0.5 cents per ESAL-Mile (in \$ US 1989) for highvolume roads. According to Nix et al. the road damage cost for a 5-axle, semi-trailer with 80,000 lbs gross weight is 1 cent per ESAL-Mile (in \$ US 1989). Over a decade later, the Railway Association of Canada (RAC, 2002) compared the actual annual cash expenditure by the Canadian government on road infrastructure maintenance and the damage costs that were estimated by Nex et al. It was revealed that cost recovery on the basis of Nex et al.'s pavement damage costs would yield only $1.5 \%$ of actual total annual expenditure (RAC, 2002; Hiroshorn, 2002).

Hajek et al. (1998), using the marginal cost method, studied the impact of changing truck weight and dimensions regulations on pavement maintenance cost in Ontario. The pavement damage cost was defined as the unit cost of providing pavement structure for one additional ESAL. The study found a marked difference in pavement maintenance marginal cost for different types of roads. Similarly, the truck volume on a given road had significant impact on marginal cost. Hajek et al estimated following models for pavement damage due to vehicle load:

EUAC $_{\text {New Pavements }}=1601+311\left(\log _{10} \text { ESALs }\right)^{2}+1394 \mathrm{~N}+\varepsilon$

EUAC $_{\text {In-Service Pavements }}=100+160\left(\log _{10} \text { ESALs }\right)^{2}+558 \mathrm{~N}+\varepsilon$

Where: $\mathrm{EUAC}_{\mathrm{New} \text { Pavements }}=$ equivalent uniform annual cost per lane for new pavements $(\$)$

EUAC $_{\text {In-Service Pavements }}=$ equivalent uniform annual costs per lane for in-service pavements (\$)

ESALs = annual number of equivalent single axle loads per lane

$\mathrm{N}=$ indicator variable ( 0 for southern and $N=1$ for northern Ontario); $\varepsilon=$ Error

The two ESAL cost functions were differentiated to obtain the marginal cost as follows:

$\operatorname{MCOST}_{\text {New Pavements }}=622(-$

$\operatorname{MCOST}_{\text {In-service Pavements }} 320 \log 10($

Where: $\operatorname{MCOST}_{\mathrm{New}}$ Pavements $=$ marginal equivalent uniform annual costs per ESAL for one lane of a new pavement structure (for a specific magnitude of ESALs imposed on the pavement structure)

$\operatorname{MCOST}_{\text {In-service Pavements }}=$ marginal equivalent uniform annual costs per ESAL for one lane of an in-service pavement structure (for a specific magnitude of ESALs imposed on the pavement structure).

The details of marginal cost estimated by Hajek et al are summarized in Table 3.3. 
Table 3.3 Marginal Pavement Cost - Ontario, Canada (Hajek et al., 1998)

\begin{tabular}{lcccc}
\hline Highway Class & \multicolumn{2}{c}{ Marginal Pavement Cost per ESAL (\$) } & \multicolumn{2}{c}{$\begin{array}{c}\text { Marginal Pavement Cost per } \\
\text { Average 5-axle Truck (\$) }\end{array}$} \\
\cline { 2 - 5 } & New Pavements & $\begin{array}{c}\text { In-service } \\
\text { Pavements }\end{array}$ & $\begin{array}{c}\text { New } \\
\text { Pavements }\end{array}$ & $\begin{array}{c}\text { In-service } \\
\text { Pavements }\end{array}$ \\
\hline Urban Freeway & 0.0025 & 0.0013 & 0.004 & 0.002 \\
\hline Major Arterial & 0.0092 & 0.0047 & 0.014 & 0.007 \\
\hline Minor Arterial & 0.0158 & 0.0082 & 0.024 & 0.012 \\
\hline Collector & 0.01401 & 0.0206 & 0.060 & 0.031 \\
\hline Local & 0.5968 & 0.3070 & 0.895 & 0.461 \\
\hline
\end{tabular}

Figure 3.1 shows the marginal pavement cost as function of ESAL both for new and in-service pavements from the Hajek study. The figure clearly depicts that the pavement damage cost varies with the number of annual ESALs. The higher the number of annual ESALs, the lower is the pavement marginal cost (i.e., \$ per ESAL). The Hajek et al. methodology can be used by highway agencies to quantify the cost of pavement damage caused by heavy vehicles under different load scenarios and for different pavement ages (new pavement vs. in-service pavements).

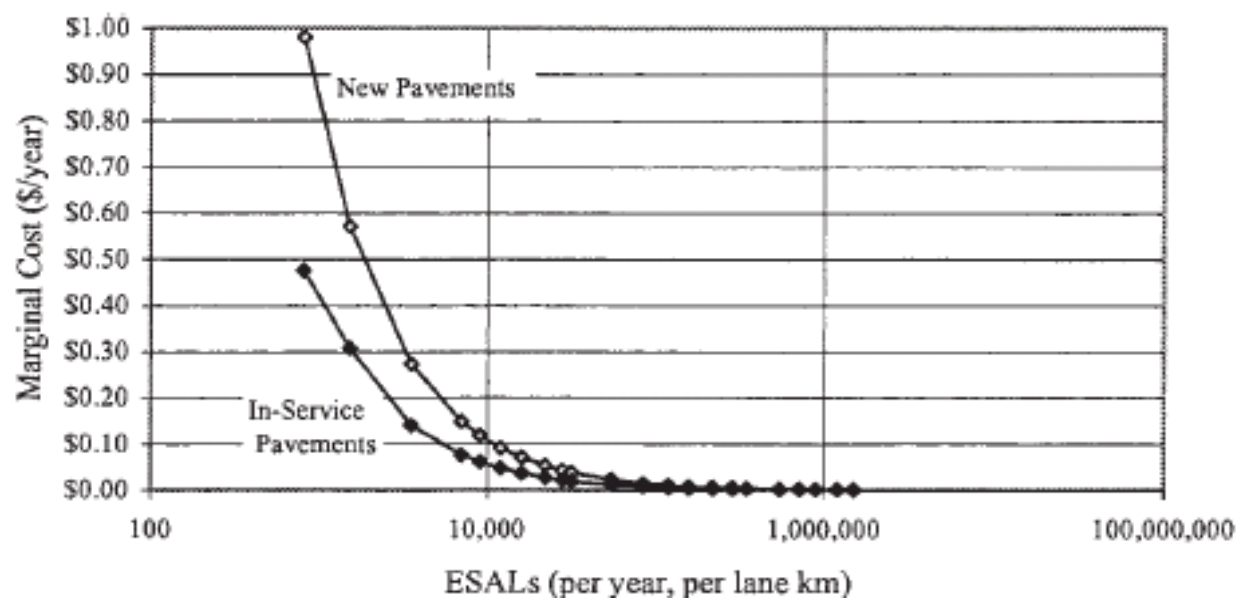

Figure 3.1 Marginal Pavement Cost as function of ESAL (Source Hajek et al., 1998)

For specific road segments or specific truck types, other past studies have also established relationships that determine the damage caused to pavement infrastructure due to each single passage of a legal-weight or overweight vehicle. This has been done using mechanistic stress-strain relationships or empirical data. The US DOT (2000) released a report in 2000 titled Comprehensive Truck Size and Weight Study. That report provided some data on how one could assess the damage 
done to the pavement by overweight vehicles. Unit pavement costs and pavement costs per unit of payload-mile by truck classification are shown in Tables 3.4 and 3.5 (USDOT, 2000). However, it can be seen even without critical analysis that the USDOT (2000) report provides unrealistic values for pavement damage cost. Consider, for example, a 5-axle double-trailer with GVW of 80,000 lbs. Table 3.4 suggests that driving this vehicle 1,000 miles on an interstate would cause pavement damage of only 3 cents (or 0.003 cents per mile). Clearly, this is far too low, compared to the findings of past studies that are discussed in this chapter. Further discussion of the information and data in that report are synthesized in Appendix 6 of this report.

Table 3.4: Unit Pavement Cost (\$/1000 miles) (USDOT, 2000).

\begin{tabular}{|c|c|c|c|c|c|c|c|c|c|c|}
\hline & \multirow[b]{3}{*}{ Weights (Pounds) } & \multicolumn{9}{|c|}{ Truck Type } \\
\hline & & \multicolumn{2}{|c|}{ Single-Unit } & \multicolumn{2}{|c|}{ Semitrailer } & \multicolumn{3}{|c|}{ Double-Trailer } & \multirow{2}{*}{\multicolumn{2}{|c|}{$\frac{\text { Triple-Trailer }}{\text { 7-Axles }}$}} \\
\hline & & 3-Axles & 4-Axles & 5-Axles & 6-Axles & 5-Axles & $\underline{\text { 7-Axles }}$ & 8-Axles & & \\
\hline & GVW & 54,000 & 64,000 & 80,000 & 90,000 & 80,000 & 100,000 & 105,000 & 100,000 & 115,000 \\
\hline & Tare & 22,600 & 26,400 & 30.49 & 31,530 & 29,320 & 38,600 & 33,470 & 41,700 & 41,700 \\
\hline & Payload & 31,400 & 37,600 & 49,510 & 58,470 & 50,680 & 61,400 & 71,530 & 58,300 & 73,300 \\
\hline Area Type & Functional Class & & & & & & & & & \\
\hline \multirow[t]{6}{*}{ Rural } & Interstate & 0.09 & 0.07 & 0.05 & 0.05 & 0.03 & 0.1 & 0.05 & 0.04 & 0.08 \\
\hline & Prin.Art. & 0.17 & 0.16 & 0.12 & 0.11 & 0.07 & 0.15 & 0.1 & 0.17 & 0.31 \\
\hline & Min.Art. & 0.37 & 0.33 & 0.29 & 0.22 & 0.32 & 0.41 & 0.21 & 0.39 & 0.75 \\
\hline & Maj.Col. & 1.38 & 1.35 & 0.9 & 0.8 & 1.17 & 1.03 & 0.65 & 1.46 & 2.95 \\
\hline & Min.Col. & 2.27 & 2.08 & 1.49 & 1.24 & 1.92 & 1.69 & 1.07 & 2.42 & 4.87 \\
\hline & Locals & 5.9 & 5.63 & 3.87 & 3.23 & 4.99 & 4.4 & 2.79 & 6.27 & 12.6 \\
\hline \multirow[t]{6}{*}{ Urban } & Interstate & 0.06 & 0.04 & 0.04 & 0.04 & 0.03 & 0.04 & 0.02 & 0.03 & 0.05 \\
\hline & Freeway\&Expressway & 0.09 & 0.06 & 0.06 & 0.05 & 0.04 & 0.07 & 0.04 & 0.09 & 0.18 \\
\hline & Prin.Art. & 0.13 & 0.12 & 0.1 & 0.09 & 0.11 & 0.09 & 0.06 & 0.13 & 0.26 \\
\hline & Min.Art. & 0.3 & 0.24 & 0.22 & 0.17 & 0.19 & 0.18 & 0.12 & 0.34 & 0.7 \\
\hline & Collector & 0.66 & 0.7 & 0.54 & 0.49 & 0.46 & 0.34 & 0.25 & 0.86 & 1.82 \\
\hline & Locals & 2.34 & 2.53 & 1.91 & 1.75 & 1.64 & 1.19 & 0.88 & 3.06 & 6.45 \\
\hline
\end{tabular}

Table 3.5: Unit Cost per Payload-mile (\$/1000 Ton-miles) (USDOT, 2000).

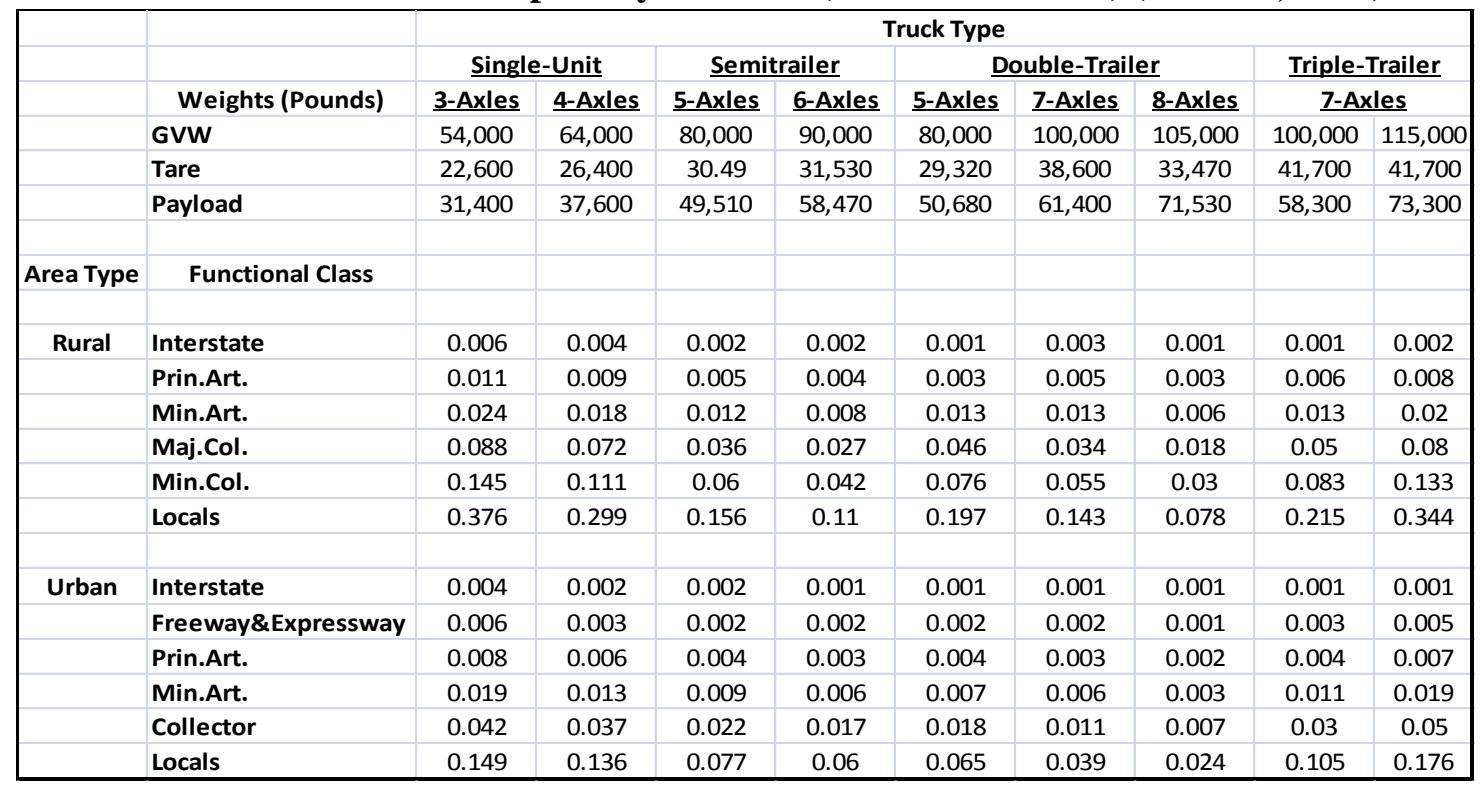


The 1997 Federal Highway Cost Allocation Study provided the initial estimates of pavement damage by heavy vehicles. An addendum to 1997 Federal Highway Cost Allocation Study was published in 2000; this not only provided marginal pavement cost but also provided estimates of marginal congestion, crash, air pollution, and noise costs. Incremental pavement deterioration cost associated with an extra mile of travel, was found to vary with pavement design and condition. Table 3.6 shows the pavement damage cost attributable to each additional mile of travel, for the different vehicle classes.

Table 3.6: FHWA (2000) Unit Pavement Cost (\$/miles) (FHWA, 2000)

\begin{tabular}{llcc}
\hline Vehicle Class & Interstate & $\begin{array}{c}\text { Marginal Pavement } \\
\text { Cost (Cents per Mile) }\end{array}$ & $\begin{array}{c}\text { Marginal Pavement Cost } \\
\text { (Cents per ESAL-Mile) }\end{array}$ \\
\hline 40,000 4-axle Single Unit Truck & Rural & 1.0 & 0.25 \\
\hline 40,000 4-axle Single Unit Truck & Urban & 3.1 & 0.78 \\
\hline 60,000 4-axle Single Unit Truck & Rural & 5.6 & 1.40 \\
\hline 60,000 4-axle Single Unit Truck & Urban & 18.1 & 4.53 \\
\hline 60,000 5-axle Combination Truck & Rural & 3.3 & 0.66 \\
\hline 60,000 5-axle Combination Truck & Urban & 10.5 & 2.10 \\
\hline 80,000 5-axle Combination Truck & Rural & 12.7 & 2.54 \\
\hline 80,000 5-axle Combination Truck & Urban & 40.9 & 8.18
\end{tabular}

Figure 3.2 and 3.3 (horizontal axes not shown to scale) illustrate how increase in payload leads to an increase in pavement damage cost, at rural and urban highways. For example, for single unit trucks at rural roads, a $50 \%$ increase in payload (from 40,000 to 60,000 lbs) is found to be associated with a five-fold increase in pavement damage cost (from 10 to 50 cents per mile); for multiple unit trucks at rural roads, a 33\% increase in payload (from 60,000 to $80,000 \mathrm{lbs}$ ) is found to be associated with a three-fold increase in pavement damage cost (from 32 to 128 cents per mile). At urban roads (Figure 3.3), the increase in damage due to load are even higher. 


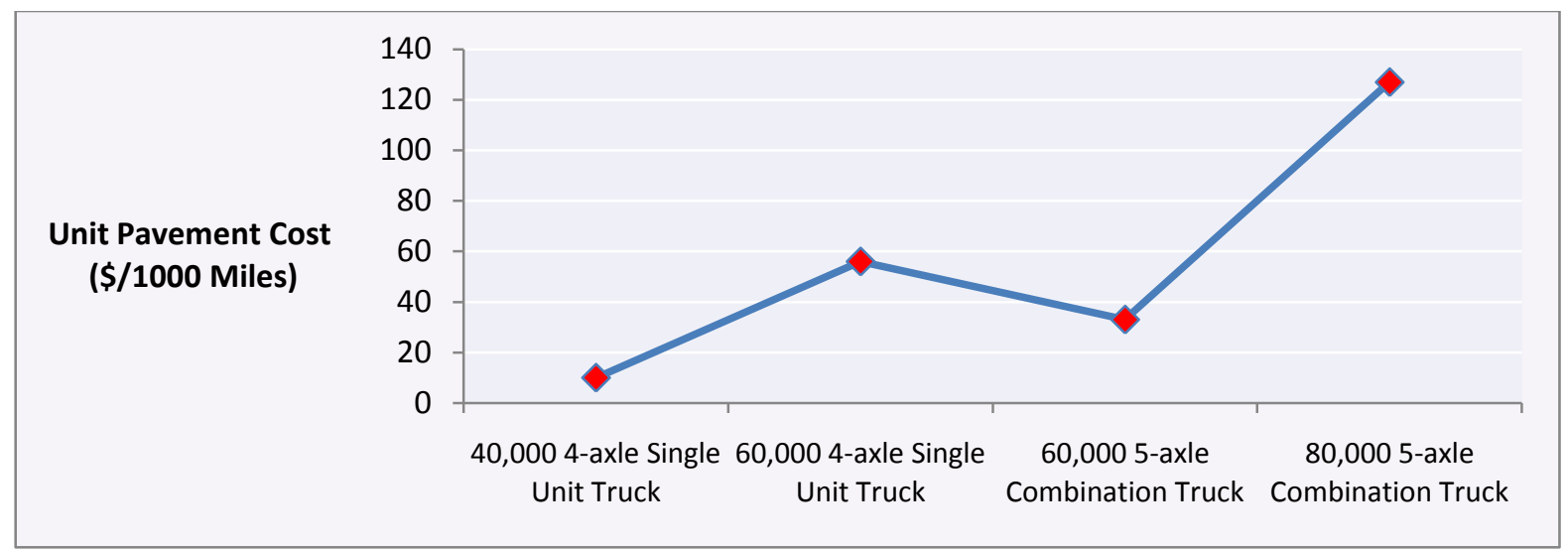

Figure 3.2: Unit Pavement Damage Cost, Various Truck Types and Loads, Rural Roads (from FHWA, 2000)

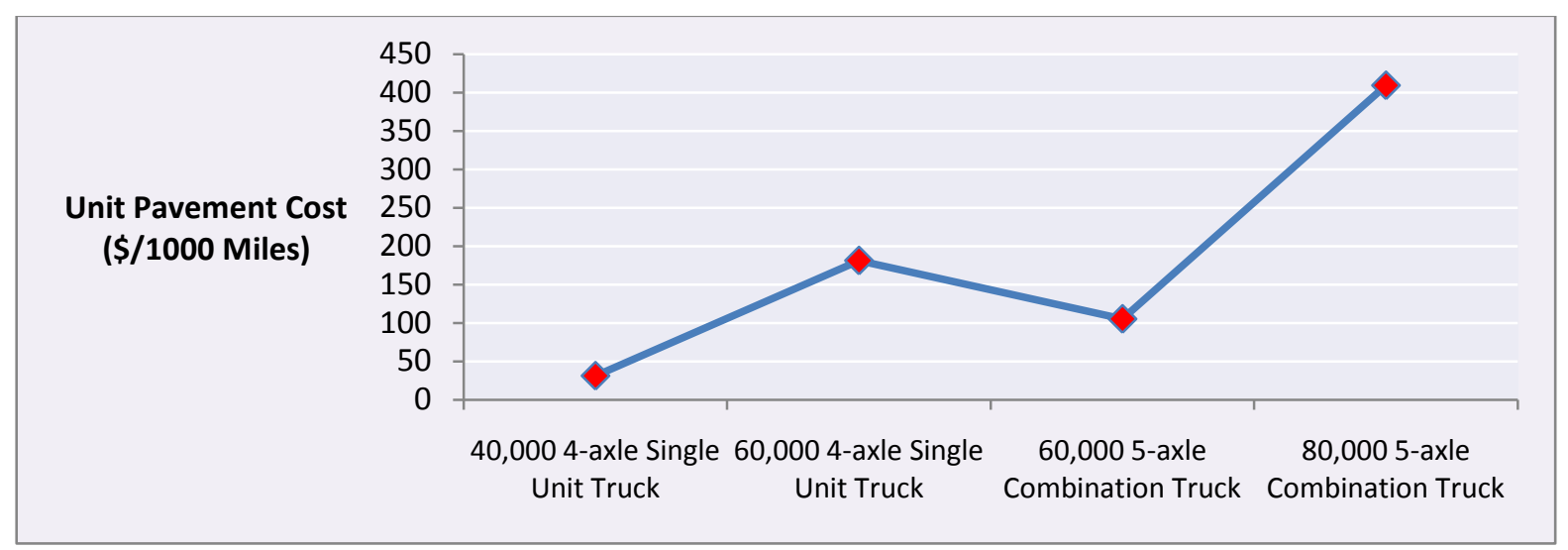

Figure 3.3: Unit Pavement Damage Cost, Various Truck Types and Loads, Urban Roads (from FHWA, 2000)

\subsection{Comparative Analysis of the Results of Past Pavement Damage Studies}

A number of studies have been carried out in recent past across the United States and Canada to quantify the pavement damage (and cost thereof) by heavy vehicles. Generally, there is a consensus in the literature that the current license fees for regular vehicles and permit fees paid by oversize and overweight vehicles recover only a very small fraction of actual amount being spent by highway agencies on pavement rehabilitation and maintenance.

Further, in many states, the current fee structure often does not provide the flexibility to assess fees based on vehicle weight or the distance it travels, the two measures of the amount of 
damage caused by a vehicle. Of the different fee structures, the most promising alternative to recover the pavement damage by vehicles is the weight-distance fee structure.

Over the years, different studies have established different rates of pavement damage and cost (Table 3.7). Considering that the 5-axle, semi-trailer with $80,000 \mathrm{lbs}$. weight is the most used heavy vehicle on United States road system, we herein present the comparative analysis across the different studies on the basis of the attributes of this truck type.

After duly correcting for the time value of money, it can be noticed that there is a marked variation in cost of pavement damage that were established by the different studies. The costs were converted to a constant year dollar value using the FHWA Construction Price Index (CPI). The equation used to calculate the dollar value in the constant-year dollars, is given as:

$C_{A Y}=C_{B Y} \times \frac{C P I_{A Y}}{C P I_{B Y}}$

Where: $\mathrm{C}_{\mathrm{AY}}=$ Cost in the analysis year;

$\mathrm{C}_{\mathrm{BY}}=$ Cost in the base year;

$\mathrm{CPI}_{\mathrm{AY}}, \mathrm{CPI}_{\mathrm{BY}}=$ the construction price indices for the analysis year and base year, respectively.

Table 3.7 Comparison of Interstate Pavement Damage across Different Studies

\begin{tabular}{cccc}
\hline Study & $\begin{array}{c}\text { Pavement damage cost (Cent } \\
\text { per Mile) -Original Study Year }\end{array}$ & $\begin{array}{c}\text { 2010 Pavement damage } \\
\text { cost (Cent per Mile) }\end{array}$ & $\begin{array}{c}\text { 2010 Pavement damage } \\
\text { cost (Cent per ESAL-Mile) }\end{array}$ \\
\hline Small et al.(1989) & 2 & 4.1 & 0.82 \\
\hline Vitaliano \& Held (1990) & 3 & 6.2 & 0.42 \\
\hline Nix et al. (1992) & 1 & 2.1 & 0.1 \\
\hline Hajek et al.(1998) & 0.3 & 0.5 & 0.0009 \\
\hline USDOT (2000) & 0.003 & 0.0045 & $3.82-12.28$ \\
\hline FHWA (2000) & $12.7-40.9$ & $19.1-61.4$ & 0.12 \\
\hline
\end{tabular}

The table shows that there is wide difference in pavement damage cost estimated and proposed by different studies. In particular, the pavement damage cost estimated by USDOT (2000) seems to be far lower than that of the other studies. These are illustrated in Figures 3.4 and 3.5. 


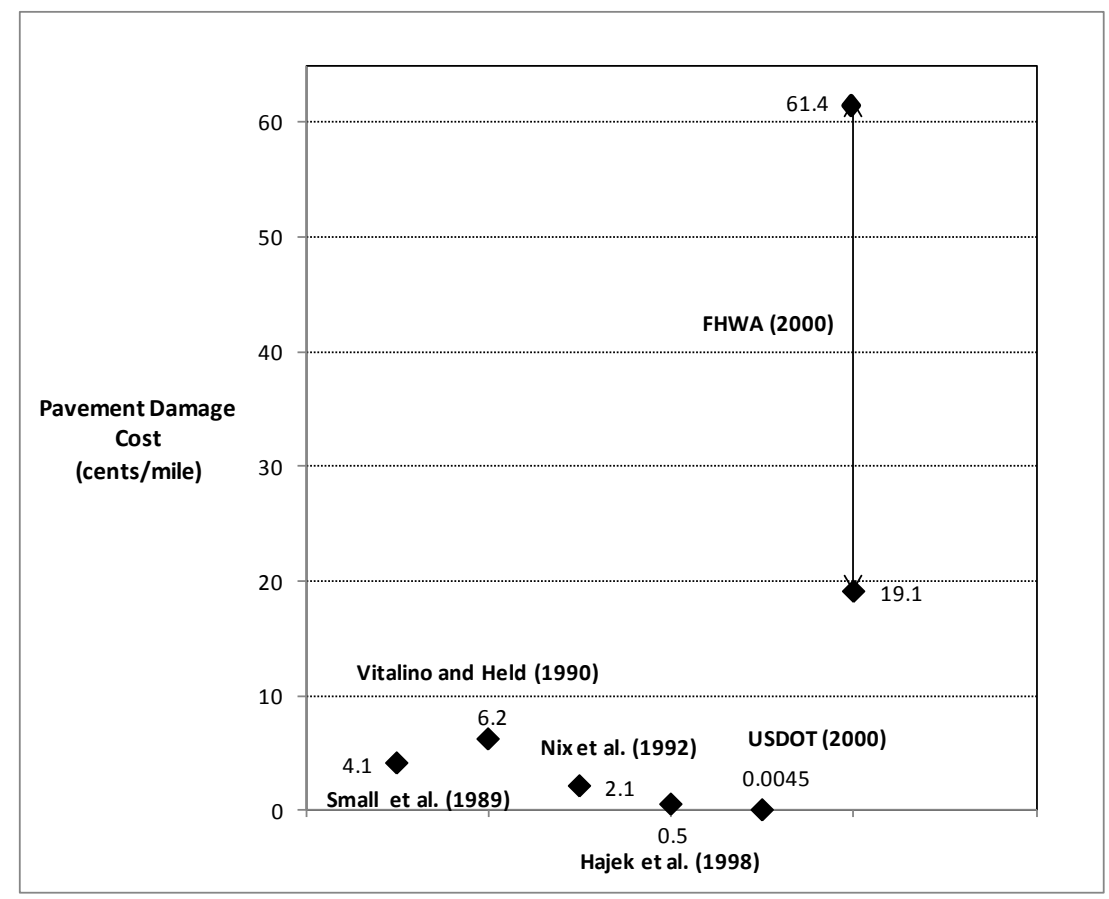

Figure 3.4 Comparison of Interstate Pavement Damage across Different Studies (cents/mile)

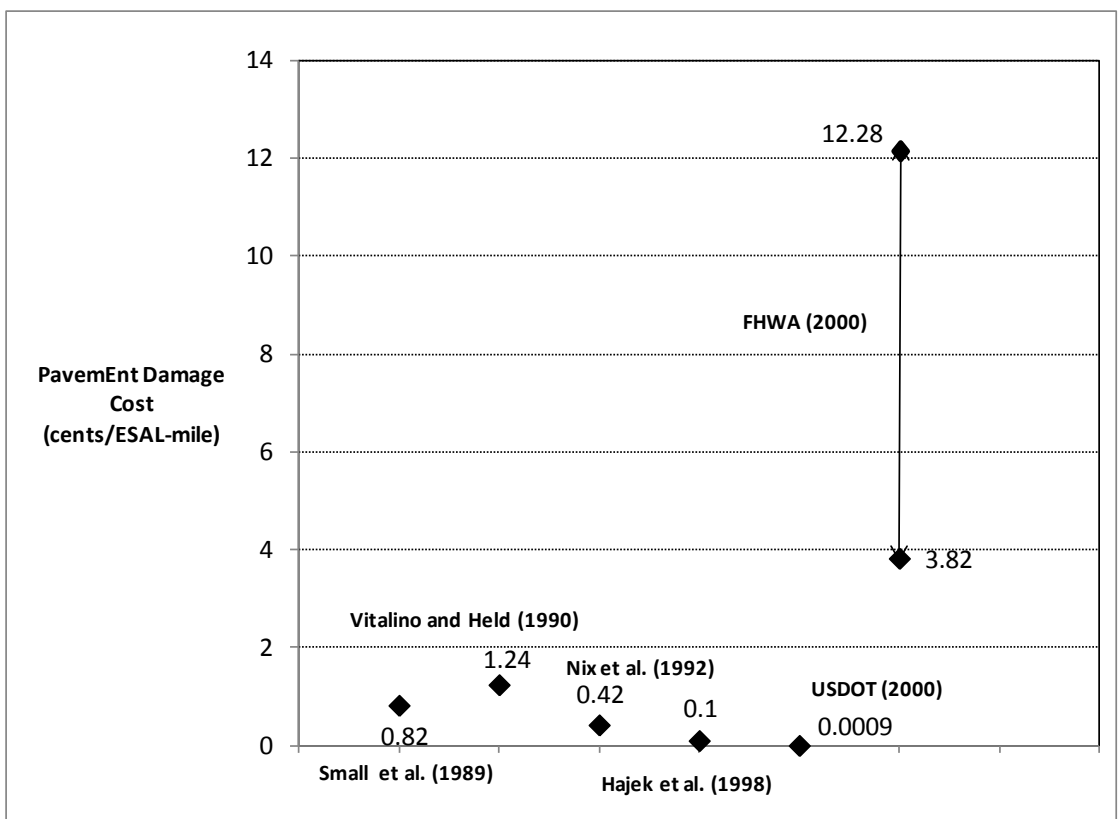

Figure 3.5 Comparison of Interstate Pavement Damage across Different Studies (cents/ESAL-mile) 


\section{CHAPTER 4: REVENUE IMPLICATIONS OF EXCESS TRUCK WEIGHTS}

\subsection{Overall Discussion}

It is important for a state to have knowledge of how much revenue can be generated from a truck permit scheme. Figure 4.1 presents the cumulative monthly revenue streams for Indiana in 2008 and the first part of 2009, from the issuance of overweight and oversize permits. From the issuance of overweight and oversize permits, the figure shows that in 2008 , just over $\$ 14$ million was collected. The source data is from the Indiana Department of Revenue. The trends for 2009 suggest that a slightly lower amount will be obtained. From a rough extrapolation of the 2009 data, it seems that the state will collect approximately $\$ 12$ million by the end of 2009. The difference between 2008 and 2009 could be attributed to the recessive state of the economy in the latter year.

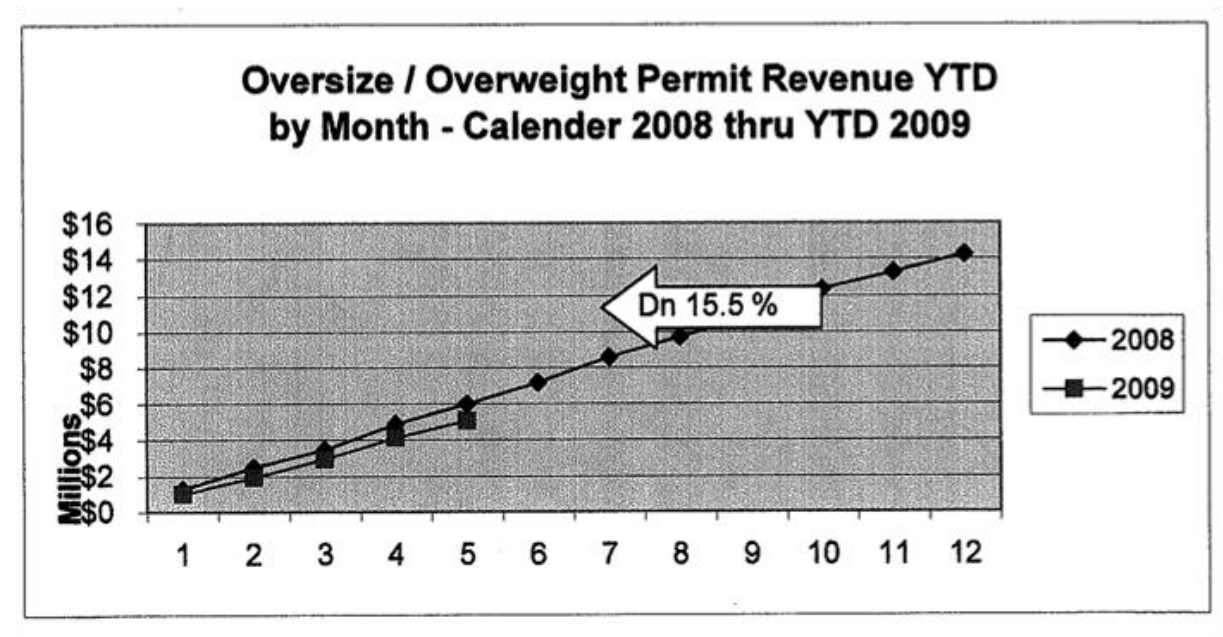

Figure 4.1: Cumulative monthly revenue streams (in \$millions) from extra-legal truck operations in Indiana, Years 2008 and 2009 (partial) 
Table 4.1 and Figure 4.2 present the yearly revenue streams from extra-legal truck operations in Indiana from Year 2002 to 2006 and part of 2007. The source data is from the Indiana Department of Revenue. The figure shows that the annual amount collected is approximately $\$ 12$ million.

The next step would be to ascertain the extent to which this amount covers the sum of the pavement damage cost and the expenditure incurred in the administration of the permitting process. While the case study in a subsequent chapter provides a methodology for answering this issue only within the context of a single hypothetical trucking company, the analysis could be extended to all truckers in the entire state, in a future research study.

Table 4.1: Yearly revenue streams from Extra-legal truck operations in Indiana, 2002-2009

\begin{tabular}{|c|c|c|c|c|c|c|c|c|}
\hline & 2002 & 2003 & 2004 & 2005 & 2006 & 2007 & 2008 & 2009 \\
\hline January & $\$ 1,258,036$ & $\$ 1,162,141$ & $\$ 976,927$ & $\$ 949,931$ & $\$ 1,016,483$ & $\$ 1,142,243$ & $\$ 1,282,549$ & $\$ 1,013,324$ \\
\hline February & $\$ 695,353$ & $\$ 578,608$ & $\$ 687,268$ & $\$ 1,100,233$ & $\$ 1,225,636$ & $\$ 461,664$ & $\$ 1,189,449$ & $\$ 920,415$ \\
\hline March & $\$ 677,994$ & $\$ 788,729$ & $\$ 861,011$ & $\$ 917,367$ & $\$ 949,984$ & $\$ 763,568$ & $\$ 994,771$ & $\$ 1,017,590$ \\
\hline April & $\$ 1,091,486$ & $\$ 1,104,585$ & $\$ 1,164,910$ & $\$ 907,877$ & $\$ 834,369$ & $\$ 660,230$ & $\$ 1,435,513$ & $\$ 1,191,024$ \\
\hline May & $\$ 1,199,505$ & $\$ 760,533$ & $\$ 635,277$ & $\$ 1,083,217$ & $\$ 1,556,480$ & $\$ 819,032$ & $\$ 1,116,064$ & $\$ 941,679$ \\
\hline June & $\$ 834,912$ & $\$ 755,190$ & $\$ 1,184,574$ & $\$ 951,632$ & $\$ 963,147$ & $\$ 565,541$ & $\$ 1,180,131$ & $\$ 1,063,284$ \\
\hline July & $\$ 1,319,582$ & $\$ 1,438,807$ & $\$ 1,330,948$ & $\$ 1,071,073$ & $\$ 1,512,325$ & $\$ 750,370$ & $\$ 1,391,342$ & $\$ 1,218,774$ \\
\hline August & $\$ 764,280$ & $\$ 527,309$ & $\$ 1,033,130$ & $\$ 1,002,639$ & $\$ 903,982$ & $\$ 720,737$ & $\$ 1,128,387$ & $\$ 991,070$ \\
\hline September & $\$ 643,471$ & $\$ 1,040,805$ & $\$ 588,779$ & $\$ 1,379,288$ & $\$ 963,212$ & $\$ 903,312$ & $\$ 1,163,554$ & $\$ 988,285$ \\
\hline October & $\$ 1,443,616$ & $\$ 1,156,842$ & $\$ 1,406,763$ & $\$ 1,099,095$ & $\$ 819,670$ & $\$ 849,997$ & $\$ 1,485,650$ & $\$ 1,200,840$ \\
\hline November & $\$ 882,074$ & $\$ 852,140$ & $\$ 986,319$ & $\$ 1,037,379$ & $\$ 1,172,514$ & $\$ 1,077,313$ & $\$ 935,437$ & $\$ 827,099$ \\
\hline December & $\$ 838,297$ & $\$ 972,978$ & $\$ 834,219$ & $\$ 865,932$ & $\$ 1,123,311$ & $\$ 973,535$ & $\$ 975,999$ & $\$ 978,758$ \\
\hline Total & $\$ 11,650,607$ & $\$ 11,140,669$ & $\$ 11,692,130$ & $\$ 12,367,669$ & $\$ 13,043,118$ & $\$ 9,689,548$ & $\$ 14,280,855$ & $\$ 11,373,384$ \\
\hline
\end{tabular}

Source: Indiana Department of Revenue

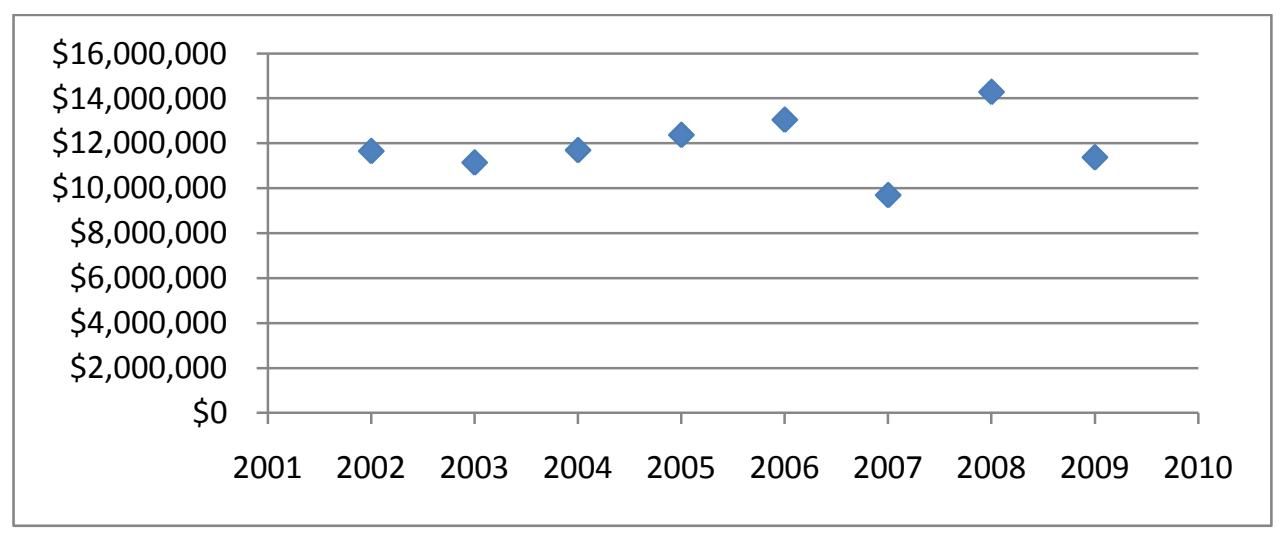

Figure 4.2: Annual Revenue from Overweight and Oversize Truck Permits 2002-2009 


\section{CHAPTER 5: CASE STUDIES}

\subsection{Introduction}

In Chapter 2, it was seen that there exist significant differences in the permit fee structures across states. It was also observed that a simple and straightforward comparison of the permit fee structure and fees could yield some useful information to assess, from the truckers perspective, the relative overall "attractiveness" of a state compared to other states. However, at the end of that chapter, it was conceded that for a more conclusive analysis, such inherent, seemingly incompatible (or, probably even irreconcilable) differences in the fee structures across the states seem to undermine the validity of the comparative evaluation, and the use of case studies may be more meaningful.

This chapter first presents two case studies to compare trucking costs borne by truckers for overweight and/or oversize trucks across the different states of the Midwest region of the United States. This comparison was carried out using input data that reflects the agencies OW/OS policies and implemented using a Microsoft Excel spreadsheet. In recognition of the differences in permit fee structures, oversize or overweight criteria (or combinations thereof), loading criteria (GVW vs. axle), and associated fees, appropriate assumptions were duly made. From the temporal perspective, the two major categories of permits used by most of the states are: the annual permit (a form of multiple-trip pricing) and the single-trip permit. As such, the case study presents two broad analysis scenarios based on these two permit categories. Where a state does not have an annual permit for certain categories (for example, Indiana has no annual permits for overweight vehicles), an "annualized permit expenditure" was determined as the product of the single trip rate and the number of single trips per year.

Also, the chapter presents case studies that illustrate how an agency could establish an annual permit for a specific trucker on the basis of (a) the sum of multiple trips using existing single-trip fee structure in order to ensure revenue neutrality (b) the revenue needed to be collected to ensure that it fully covers the pavement damage incurred by $\mathrm{OW}$ vehicle operations. It may be noted that the annual permit fee to be established in (b) is expected to be higher compared to that of (a).

The input data for the scenarios are provided below. The specific input data shown below are for illustration only. The Excel spreadsheet has been provided as an addendum to this report. Using the spreadsheet, the analyst can input appropriate values for each data item to generate the corresponding results. 


\subsection{Input Data for Case Study I and II}

Case Study (Scenario) 1: Multiple-trip Permit Expenditures Summed up Over 1 Year

Consider a trucking company with 200 trucks with the following details as provided in Table 5.1.

Table 5.1 Hypothetical Number of Trucks in each Weight and Size Category

\begin{tabular}{|c|c|c|c|c|c|c|c|}
\hline \multicolumn{2}{|c|}{ Gross Vehicle Weight (Ibs) } & \multirow[t]{2}{*}{$<80,000$} & \multirow{2}{*}{$\begin{array}{c}80,000 \text { to } \\
90,000\end{array}$} & \multirow{2}{*}{$\begin{array}{c}90,001 \text { to } \\
100,000\end{array}$} & \multirow{2}{*}{$\begin{array}{c}100,001 \\
\text { to } \\
120,000\end{array}$} & \multirow{2}{*}{$\begin{array}{c}120,001 \\
\text { to } \\
150,000\end{array}$} & \multirow[t]{2}{*}{$>150,000$} \\
\hline $\begin{array}{l}\text { Size } \\
\text { Group }\end{array}$ & Dimensions (ft.) & & & & & & \\
\hline \multirow{3}{*}{1} & Length: $<70^{\prime}$ & \multirow{3}{*}{15} & \multirow{3}{*}{15} & \multirow{3}{*}{10} & \multirow{3}{*}{10} & & \\
\hline & Width: < 10' & & & & & & \\
\hline & Height: < 13' -6"' & & & & & & \\
\hline \multirow{3}{*}{2} & Length: $71^{\prime}-80^{\prime}$ & \multirow{3}{*}{5} & \multirow{3}{*}{10} & \multirow{3}{*}{20} & \multirow{3}{*}{30} & \multirow{3}{*}{10} & \\
\hline & Width: 10' - 12' & & & & & & \\
\hline & Height: 13' -6" - 14'- 6" & & & & & & \\
\hline \multirow{3}{*}{3} & Length: 81' - 100' & & \multirow{3}{*}{5} & \multirow{3}{*}{5} & \multirow{3}{*}{5} & \multirow{3}{*}{5} & \multirow{3}{*}{5} \\
\hline & Width: 12'-1" - 14' & & & & & & \\
\hline & Height: 14' -7"' - 16' & & & & & & \\
\hline \multirow{3}{*}{4} & Length: 101' - 120' & \multirow{3}{*}{5} & & & \multirow{3}{*}{5} & \multirow{3}{*}{20} & \multirow{3}{*}{10} \\
\hline & Width: 14'-1" - 16' & & & & & & \\
\hline & Height: 14' -6" - 15'- 6" & & & & & & \\
\hline \multirow{3}{*}{5} & Length: >120' & & & & & \multirow{3}{*}{10} & \\
\hline & Width: > 16' & & & & & & \\
\hline & Height: > 15'-6" & & & & & & \\
\hline
\end{tabular}

For example, the trucking company has 30 trucks that are of GVW 100,001-120,000 lbs; length 71-80 ft; width 10-12 ft; and height 13.6-14.16 ft.

Assume that the annual Vehicles Miles Traveled per Truck $=600$ Miles

Assume that the number of districts crossed during the trip $=5$ (for district fees)

Assume that the trucking operator pays an annual permit that is equal to the annual blanket permit amount, or where none exists, the annual sum of the single trips made within the year.

It is assumed that this trucking company operates in each of the eight Midwest states with the above fleet. The overall yearly cost incurred by the trucker in each state, based on the fee structure of the state (see Tables 5.2 to 5.7), is then calculated. 
Case Study (Scenario) 2: Single-trip Permits

Input Data are as follows: Consider a trucking company with 200 trucks.

Number of trucks in each category of weight and size is given in Table 5.1.

Vehicles Miles Traveled per Truck per Trip $=300$ Miles

Assume that the number of districts crossed during each trip $=5$ (for district fees)

Assume that the number of bridges crossed during each trip $=60$ (for bridge fees)

It is assumed that this trucking company operates in each of the eight Midwest states with the above fleet. The overall yearly cost incurred by the trucker in each state, based on the fee structure of the state, is then calculated.

\subsection{Results of the Case Studies}

\subsubsection{Case Study I (Scenario I): Annual Blanket Permit or Annualized Multiple-Trip Permits}

Using the default data described in Section 5.2, the results for this scenario are provided in the Excel spreadsheets that accompany this report. A synthesis of these results is provided in tables and charts below (see total amount highlighted in bold font (last row) in Tables 5.2 to 5.7 and Figure 5.1. As expected, the total annual expenditure on permits is relatively high at states such as Indiana where there are no annual blanket permits for overweight trucks and thus the total annual permit revenue to the agency (that is, total annual cost to the trucking operator) is equal to the sum of individual single trips made over the entire year.

Table 5.2 Case Study Trucking Costs, INDIANA Operations - Annual Expenditure on Permits

\begin{tabular}{|c|c|c|c|c|}
\hline \multicolumn{2}{|c|}{ Oversize Only } & \multicolumn{2}{c|}{ Over WT. Only } & Oversize / Over WT. \\
\cline { 1 - 3 } Up to $13^{\prime}-6^{\prime \prime}$ & $>13^{\prime}-6^{\prime \prime}$ & $80-108$ Kips & $108-150$ Kips & \\
\hline 15 & 10 & 15 & 10 & 140 \\
\hline$\$ 0$ & $\$ 405$ & $\$ 230$ & $\$ 380$ & $\$ 405$ \\
\hline$\$ 0$ & $\$ 4,050$ & $\$ 3,450$ & $\$ 3,800$ & $\$ 56,700$ \\
\hline \multicolumn{3}{|c|}{$\$ \mathbf{6 8 8 , 0 0 0}$} \\
\hline
\end{tabular}

Note: for OS, Annual permit rate was used; for $\mathrm{OW}$, single trip rate was used as IN does not have an annual trip rate for OW only category.

Table 5.3 Case Study Trucking Costs, ILLINOIS Operations - Annual Expenditure on Permits

\begin{tabular}{|c|c|c|c|c|c|c|}
\hline \multicolumn{5}{|c|}{ Oversize Only } & \multicolumn{2}{|c|}{ Oversize / Overweight } \\
\hline $\begin{array}{c}\text { (lengh } \leq 70^{\prime}, \text { width } \\
\leq 10, \\
\left.\text { Height } \leq 14^{\prime} 6^{\prime \prime}\right)\end{array}$ & $\begin{array}{c}\text { (lengh } \leq 70^{\prime}, \text { width } \\
\leq 10, \\
\left.\text { Height } \leq 14^{\prime} 6^{\prime \prime}\right)\end{array}$ & $\begin{array}{c}\text { (lengh } \leq 70^{\prime}, \text { width } \\
\leq 10, \\
\left.\text { Height } \leq 14^{\prime} 6^{\prime \prime}\right)\end{array}$ & $\begin{array}{c}\text { (lengh } \leq 70^{\prime}, \text { width } \leq \\
10, \\
\left.\text { Height } \leq 14^{\prime} 6^{\prime \prime}\right)\end{array}$ & $\begin{array}{c}\text { (lengh } \leq 70^{\prime}, \text { width } \\
\leq 10, \\
\left.\text { Height } \leq 14^{\prime} 6^{\prime \prime}\right)\end{array}$ & $\begin{array}{c}6 \text { Axle up } \\
\text { to } \\
100,000 \mathrm{lbs}\end{array}$ & $\begin{array}{c}6 \text { Axle up } \\
\text { to } \\
120,000 \mathrm{lbs} \\
\end{array}$ \\
\hline 15 & 5 & 0 & 5 & 0 & 40 & 100 \\
\hline$\$ 21$ & $\$ 30$ & $\$ 40$ & $\$ 60$ & $\$ 125$ & $\$ 130$ & $\$ 295$ \\
\hline$\$ 516$ & $\$ 351$ & $\$ 0$ & $\$ 501$ & $\$ 0$ & $\$ 5,350$ & $\$ 30,400$ \\
\hline
\end{tabular}

Note: for OS, single-trip permit rate was used as IL does not have an annual trip rate for that category; for OW, routine/multiple trip 
Table 5.4 Case Study Trucking Costs, WISCONSIN Operations - Annual Expenditure on Permits

\begin{tabular}{|c|c|c|c|c|}
\hline \multicolumn{2}{|c|}{ Oversize Only } & \multicolumn{2}{c|}{ Overweight Only } & \multirow{2}{*}{$\begin{array}{c}\text { Oversize/ } \\
\text { Overweight }\end{array}$} \\
\cline { 1 - 3 } $\begin{array}{c}\text { Trucks Exceeding } \\
\text { length limits }\end{array}$ & $\begin{array}{c}\text { Trucks Exceeding width } \\
\text { or height limits }\end{array}$ & $<90$ Kips & $90-100$ Kips & 140 \\
\hline 15 & 10 & 15 & 20 & $\$ 350$ \\
\hline$\$ 0$ & $\$ 90$ & $\$ 200$ & $\$ 350$ & $\$ 49,000$ \\
\hline$\$ 0$ & $\$ 900$ & $\$ 60,200$ & $\$ 7,000$ & \\
\hline \multicolumn{3}{|c|}{}
\end{tabular}

Note: Estimates are based on multiple trip permit rate (for 12 months period).

Table 5.5 Case Study Trucking Costs, IOWA \& OHIO Operations - Annual Expenditure on Permits

\begin{tabular}{|c|c|c|}
\hline IA & \multicolumn{2}{|c|}{ OH } \\
\hline \multirow{2}{*}{ Oversize/ Overweight } & Oversize Only (Routine) & Oversize/Overweight \\
\cline { 2 - 3 } & Michigan Legal & Super load(Michigan Legal) \\
\hline 130 & 95 & 50 \\
\hline$\$ 300$ & $\$ 470$ & $\$ 630$ \\
\hline$\$ 39,000$ & $\$ 44,650$ & $\$ 31,500$ \\
\hline$\$ 39,000$ & & $\$ \mathbf{7 6 , 1 5 0}$ \\
\hline
\end{tabular}

Note: Based on Annual Permit rates

Table 5.6 Case Study Trucking Costs, MONTANA \& MINNESOTA Operations - Annual Expenditure on Permits

\begin{tabular}{|c|c|c|}
\hline \multicolumn{2}{|c|}{$\mathrm{MO}$} & $\mathrm{MN}$ \\
\hline Oversize Only & Overweight Only & Oversize / Overweight \\
\hline $\begin{array}{c}\mathrm{HT}=14^{\prime}-16^{\prime} ; \text { width }=8^{\prime} 6^{\prime \prime} ; \\
\text { Length }=65^{\prime}-150\end{array}$ & 80-160 Kips & $\begin{array}{c}\text { HT }>13^{\prime} 6^{\prime \prime} ; \text { width }>8^{\prime} 6^{\prime \prime} ; \text { Length }>75^{\prime} ; \\
145 \text { kips }>\text { Wt }>80 \text { kips }\end{array}$ \\
\hline 25 & 175 & 160 \\
\hline$\$ 400$ & $\$ 400$ & $\$ 120$ \\
\hline$\$ 10,000$ & $\$ 70,000$ & $\$ 19,200$ \\
\hline \multicolumn{2}{|c|}{$\$ 80,000$} & $\$ 19,200$ \\
\hline
\end{tabular}

Note: Based on Annual Permit rates

Table 5.7 Case Study Trucking Costs for MICHIGAN and KENTUCKY Operations Annual Expenditure on Permits

\begin{tabular}{|c|c|c|}
\hline $\mathrm{MI}$ & \multicolumn{2}{|c|}{ KY } \\
\hline Oversize / Overweight & \multicolumn{2}{|c|}{ Oversize/ Overweight } \\
\hline $\begin{array}{c}\mathrm{HT}>14^{\prime} ; \text { width }>14^{\prime} 6^{\prime \prime} ; \\
\text { Length }>85^{\prime} ; 145 \mathrm{kips}>\mathrm{Wt}>80 \mathrm{kips}\end{array}$ & Non-divisible $<14^{\prime}$ wide & Non-divisible $<14^{\prime}-16^{\prime}$ wide \\
\hline 160 & 95 & 45 \\
\hline$\$ 150$ & $\$ 250$ & $\$ 500$ \\
\hline$\$ 24,000$ & $\$ 23,750$ & $\$ 22,500$ \\
\hline$\$ 24,000$ & \multicolumn{2}{|c|}{$\$ 46,250$} \\
\hline
\end{tabular}

Note: Based on Annual Permit rates 


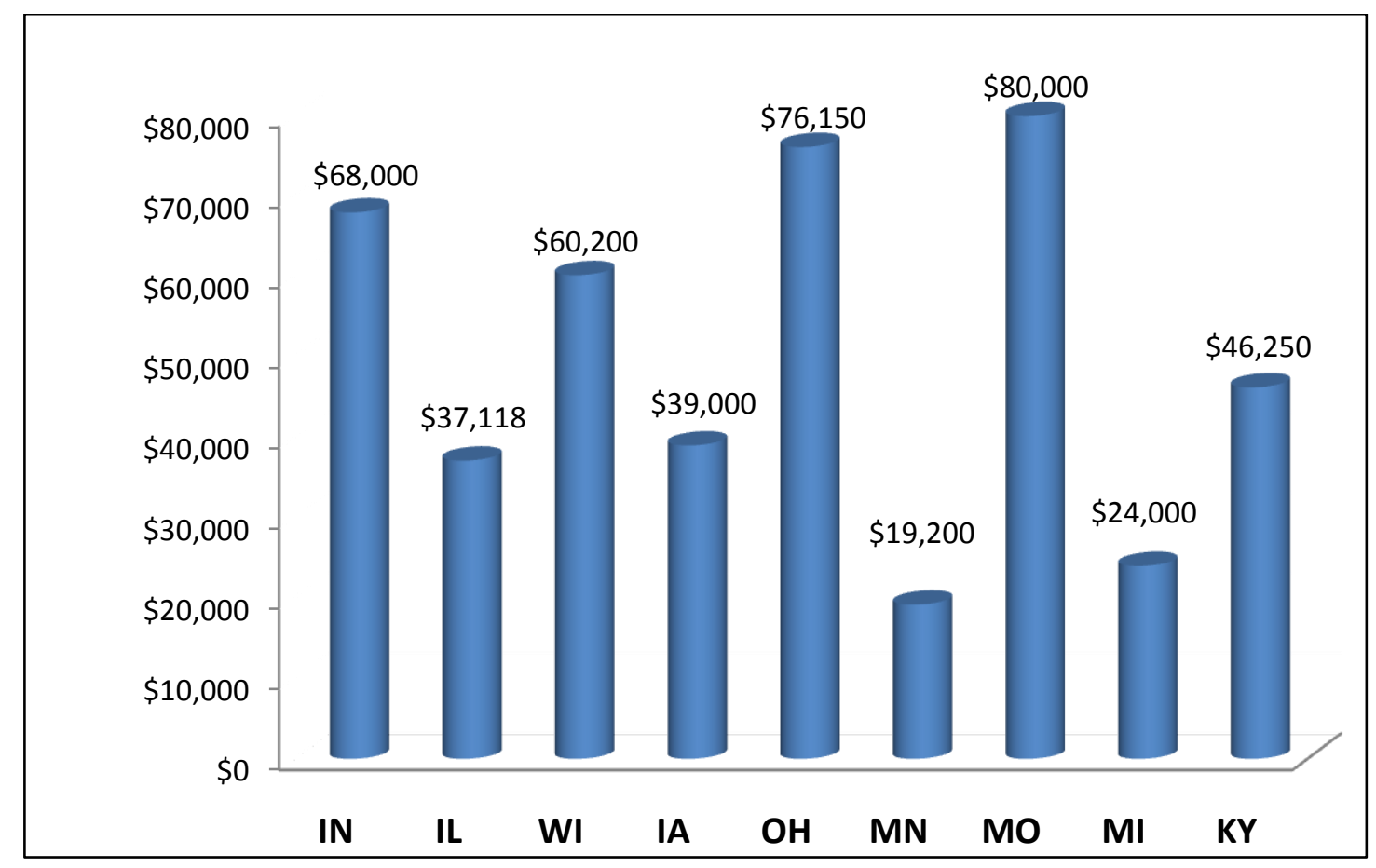

Figure 5.1 Results of the Case Study I (Annual Expenditure on Permits)

(Trucking Permit Costs for Overweight and/or Oversize Trucks Across of Midwest States, for a Hypothetical Trucking Company, see accompanying spreadsheet)

\subsubsection{Case Study II (Scenario II): Single-trip Permits}

The results for this scenario are provided as defaults in the Excel spreadsheets. A synthesis of these results is provided in tables and charts below (see the "Trucker's total permit cost" row in the Tables 5.8 to 5.13 and Figure 5.2.)

Table 5.8 Case Study Trucking Costs for INDIANA Operations - Single-trip Permit

\begin{tabular}{|c|c|c|c|c|}
\hline \multicolumn{2}{|c|}{ Oversize Only } & \multicolumn{2}{c|}{ Overweight Only } & $\begin{array}{c}\text { Oversize / } \\
\text { Overweight }\end{array}$ \\
\hline Up to 13'-6” & $>13^{\prime}-6^{\prime \prime}$ & $80-108$ Kips & $108-150$ Kips & 140 \\
\hline 15 & 10 & 25 & 10 & $\$ 200$ \\
\hline$\$ 20$ & $\$ 30$ & $\$ 125$ & $\$ 200$ & $\$ 28,000$ \\
\hline$\$ 300$ & $\$ 300$ & $\$ 3,125$ & $\$ 2,000$ & \\
\hline
\end{tabular}


Table 5.9 Case Study Trucking Costs for ILLINOIS Operations - Single-trip Permit

\begin{tabular}{|c|c|c|c|c|c|c|}
\hline \multicolumn{5}{|c|}{ Oversize Only } & \multicolumn{2}{|c|}{ Oversize/ Overweight } \\
\hline $\begin{array}{c}\text { (lengh } \leq 70^{\prime}, \\
\text { width } \leq 10, \\
\left.\text { Height } \leq 14^{\prime} 6^{\prime \prime}\right)\end{array}$ & $\begin{array}{c}\text { (lengh } \leq 70^{\prime}, \\
\text { width } \leq 10, \\
\left.\text { Height } \leq 14^{\prime} 6^{\prime \prime}\right)\end{array}$ & $\begin{array}{c}\text { (lengh } \leq 70^{\prime}, \\
\text { width } \leq 10, \\
\left.\text { Height } \leq 14^{\prime} 6^{\prime \prime}\right)\end{array}$ & $\begin{array}{c}\text { (lengh } \leq 70^{\prime}, \\
\text { width } \leq 10, \\
\left.\text { Height } \leq 14^{\prime} 6^{\prime \prime}\right)\end{array}$ & $\begin{array}{c}\text { (lengh } \leq 70^{\prime}, \\
\text { width } \leq 10, \\
\left.\text { Height } \leq 14^{\prime} 6^{\prime \prime}\right)\end{array}$ & $\begin{array}{l}6 \text { Axle up to } \\
100,000 \mathrm{lbs}\end{array}$ & $\begin{array}{l}6 \text { Axle up to } \\
120,000 \mathrm{lbs}\end{array}$ \\
\hline 15 & 5 & 0 & 5 & 0 & 40 & 100 \\
\hline$\$ 62$ & $\$ 71$ & $\$ 81$ & $\$ 101$ & $\$ 166$ & $\$ 116$ & $\$ 116$ \\
\hline$\$ 930$ & $\$ 355$ & $\$ 0$ & $\$ 505$ & $\$ 0$ & $\$ 4,790$ & $\$ 12,500$ \\
\hline \multicolumn{7}{|c|}{$\$ 19,080$} \\
\hline
\end{tabular}

Table 5.10 Case Study Trucking Costs for WISCONSIN Operations - Single-trip Permit

\begin{tabular}{|c|c|c|}
\hline \multicolumn{3}{|c|}{ Oversize Only } \\
\hline Trucks Exceeding length limits & $\begin{array}{c}\text { Trucks Exceeding width or } \\
\text { height limits }\end{array}$ & $\begin{array}{c}\text { Trucks Exceeding both width } \\
\text { and height limits }\end{array}$ \\
\hline 75 & 75 & 75 \\
\hline$\$ 666$ & $\$ 681$ & $\$ 686$ \\
\hline$\$ 49,950$ & $\$ 51,075$ & $\$ 51,450$ \\
\hline \multicolumn{3}{|c|}{$\mathbf{\$ 1 5 2 , 4 7 5}$} \\
\hline
\end{tabular}

Table 5.11 Case Study Trucking Costs for IOWA and OHIO Operations - Single-trip Permit

\begin{tabular}{|c|c|c|}
\hline IA & \multicolumn{2}{|c|}{ OH } \\
\hline Oversize/ Overweight & Oversize Only(Routine) & Oversize/ Overweight \\
\cline { 2 - 3 } & Michigan Legal & Super load(Michigan Legal) \\
\hline 140 & 95 & 50 \\
\hline$\$ 10$ & $\$ 100$ & $\$ 200$ \\
\hline$\$ 1,400$ & $\$ 9,500$ & $\$ 10,000$ \\
\hline $\mathbf{1 1 , 4 0 0}$ & & $\mathbf{\$ 1 9 , 5 0 0}$ \\
\hline
\end{tabular}

Table 5.12 Case Study Trucking Costs for MISSOURI Operations - Single-trip Permit

\begin{tabular}{|c|c|c|c|c|}
\hline Oversize Only & \multicolumn{4}{|c|}{ Over WT. Only Oversize / Overweight } \\
\hline $\begin{array}{c}\text { Height=14'-16'; } \\
\text { Width }<8^{\prime} 6^{\prime \prime} ; \\
\text { Length=65'-150 }\end{array}$ & $80-90$ Kips & $90-100$ Kips & $100-120$ Kips & $120-150$ Kips \\
\hline 25 & 15 & 25 & 40 & 45 \\
\hline$\$ 15$ & $\$ 15$ & $\$ 15$ & $\$ 15$ & $\$ 15$ \\
\hline$\$ 375$ & $\$ 225$ & $\$ 875$ & $\$ 2,200$ & $\$ 3,375$ \\
\hline \multicolumn{4}{|c|}{$\$ 7,050$} \\
\hline
\end{tabular}

Table 5.13 Case Study Trucking Costs for MINNESOTA, MICHIGAN and KENTUCKY Operations - Single-trip Permit

\begin{tabular}{|c|c|c|c|}
\hline $\mathrm{MN}$ & $\mathrm{MI}$ & \multicolumn{2}{|c|}{ KY } \\
\hline Oversize/Overweight & Oversize/Overweight & \multicolumn{2}{|c|}{ Oversize/Overweight } \\
\hline $\begin{array}{c}\text { Height }>13^{\prime} 6^{\prime \prime} ; \text { Width }>8^{\prime} 6^{\prime \prime} ; \\
\text { Length }>75^{\prime} \\
145 \text { kips }>\text { Weight }>80 \text { kips }\end{array}$ & $\begin{array}{c}\text { Height }=14^{\prime \prime} ; \text { Width }>14^{\prime} 6^{\prime \prime} ; \\
\text { Length }>85^{\prime} \\
145 \text { kips }>\text { Weight }>80 \text { kips }\end{array}$ & $\begin{array}{l}\text { Non-divisible } \\
<14^{\prime} \text { Wide }\end{array}$ & $\begin{array}{l}\text { Non-divisible } \\
<14^{\prime}-16^{\prime} \text { Wide }\end{array}$ \\
\hline 160 & 160 & 95 & 45 \\
\hline$\$ 25$ & $\$ 50$ & $\$ 60$ & $\$ 60$ \\
\hline$\$ 4,000$ & $\$ 8,000$ & $\$ 5,700$ & $\$ 2,700$ \\
\hline$\$ 4,000$ & $\$ 8,000$ & \multicolumn{2}{|c|}{$\$ 8,400$} \\
\hline
\end{tabular}




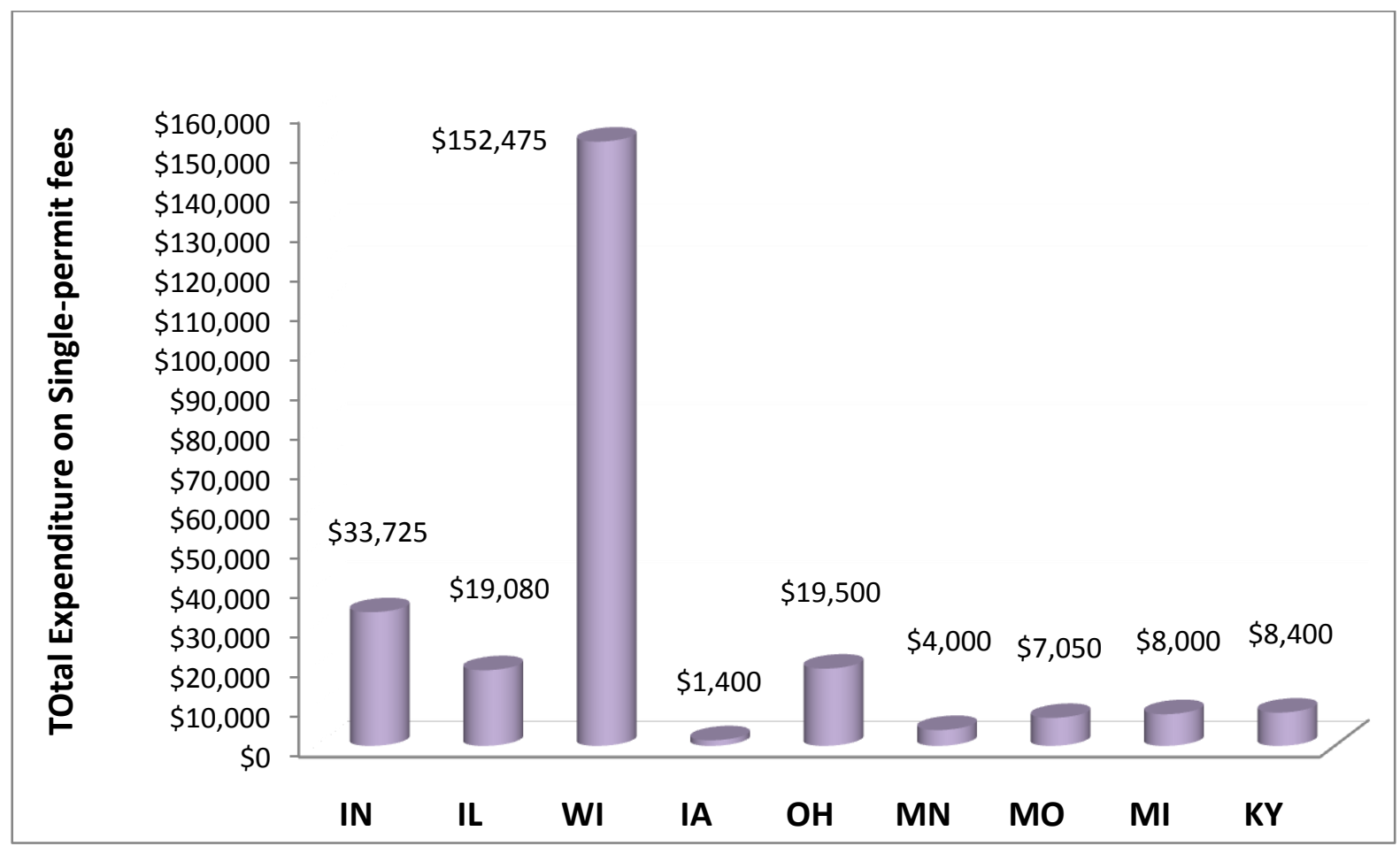

Figure 5.2 Results of the Case Study II (Single-trip Permit)

(Trucking Permit Costs for Overweight and/or Oversize Trucks Across of Midwest States, for the

Hypothetical Trucking Company, see accompanying spreadsheet)

\subsection{A Discussion of Issues Relating to the Case Studies I and II}

As mentioned in the Introduction to this chapter, due to the diversity across the states of the permit structures, permitting regulations, OS/OW definitions and sub classes, and permit attributes, a straightforward comparison across states is difficult. In response to this challenge, this chapter makes an attempt to carry out a comparative evaluation of permitting fees (as impacted on the trucking operator). This evaluation is designed to accommodate, as much as possible, the nuances, peculiarities, and complexities in the permit fee structures across all states. As discussed earlier in this report, no two states fee structures are identical even though a few states, such as Michigan and Minnesota have some similarities.

In view of these differences in the states fee structures, the case studies were carried out under a number of simplifying assumptions where were stated early in this chapter. It is important to note that any conclusions from the case studies are based on these assumptions. 
The explicit consideration of mileage in assessing permit fees is done by relatively few states. The inclusion of that criterion thus further complicates efforts to compare permit fees across the states. This is because for states that consider the distance travelled by the overweight/oversize truck, the total fee to be paid can be calculated only after the distance traveled is known. For the case studies in this chapter, we assumed that each OW or OS truck travels a total distance of 600 miles per year. If the actual distance is higher or lower, the results of the comparative evaluation could be significantly different.

In our case study setting, the trucking company is assumed to have a total of 200 trucks of different sizes and weight classes as shown in the Table 4.1. In a real case or hypothetical situation where the fleet size and the distribution of trucks in each weight and dimension category are different from the defaults in our spreadsheets, the analyst may enter the spreadsheet and change the value accordingly. Also, different permit structure scenarios can be expected to get very different outcomes of the comparison.

For the scenario involving single-trip permits, the comparison is purely based on just one trip per truck. The cost to the trucker (i.e., the revenue generated for the agency) can be calculated by considering the number of trips that each truck will make per year.

In certain states, single permits are valid only for a certain time period such as 5 or 15 days. This can complicate the analysis, particularly when there are significant differences in the number of trips made within this time period. Another confounding issue could be that of permit extension possibilities or acquiring a completely new permit for subsequent trips. Our case studies involve a simplified scenario where the trucker obtains either an annual permit (Case Study 1) or a single permit (Case Study 2).

For states with complicated fee structures, a greater number of assumptions were made in the case study in order to facilitate the comparison. A case in point is the state of Illinois where the permitting criteria and sub-classes are numerous and intertwined: axle loads, distance, type of commodity being hauled, weight, and size are among the several criteria considered. While inclusion of these considerations renders the permit fees more equitable within at the state, it also adds complexity in the comparative evaluation. For the case studies, therefore, a number of simplifying assumptions were made for this state in a bid to arrive at a fair comparison. 


\subsection{Case Study III: Calculation of Total Annual Permit Amount to be Paid by another Hypothetical Company on the basis of Current Single-trip Fee Structure}

A hypothetical trucking company with a number of $134,000 \mathrm{lb}$ trucks wishes to undertake a total of 10,000 trips per year. It is desired to determine the total permit amount to be paid by this company in one year on the basis of current single-trip fee structure in State of Indiana. From the highlighted fee structure in Table 5.14 (see arrow), we have:

Single trip expense $=\$ 20+\$ 0.35 *$ Truck Miles (up to 108,000 lbs GVW)

Single trip expense $=\$ 20+\$ 10+\$ 0.60 *$ Truck Miles (from 108,000 lbs to $150,000 \mathrm{lbs}$ GVW)

Single trip expense $=\$ 20+\$ 10+\$ 1.00 *$ Truck Miles (from 150,000 lbs to 200,000 lbs GVW)

Using Equations (1)-(3), the single-trip expenses for different truck-miles per trip and various truck weight categories were estimated (Figure 5.3 and Table 5.15).

This was used to determine the appropriate fee for a hypothetical trucker that has requested annual permits for 10,000 trips per year to be made by 134,000 lb GVW vehicles on the basis of the current revenue structure.

The analysis is as follows:

Truck GVW $=134,000 \mathrm{lbs} \quad$ (GVW Category: 108,000 - 150,000 lbs)

Number of Trips $=10,000$

Assuming the OW vehicle is moving 300 miles in each single trip (as highlighted in Table 15.5 and Figure 5.36)

Permit expense for trucks (with GVW of 134,000 lbs and 300-mile trip length)

$=\$ 30+\$ 0.60 \times 300$ truck miles $=\$ 210$ per trip (Table 5.15, Figure 5.3, and Equation (2))

Total Permit expense for 10,000 Trips

$=210 \times 10,000=\$ 2,100,000$

Similarly, single-trip permit expenses for various weight categories and trip lengths can be estimated using Table 15.5 and plots in Figure 5.3.

Note: For purposes of our computations, 10,000 trips in a year is equivalent to:

1 truck making 10,000 trips in a year, or

10,000 trucks making 1 trip each in a year, or 500 trucks making 200 trips each in a year, or 20 trucks making 5,000 trips in a year, etc. 
Table 5.14 Permit Fee Structure for Indiana State

\begin{tabular}{|c|c|c|c|c|c|c|}
\hline Category & Type & Forms & Single Trip Fee & $\begin{array}{l}90 \text { Day } \\
\text { Fee }\end{array}$ & $\begin{array}{c}\text { Annual } \\
\text { Fee }\end{array}$ & \multirow{4}{*}{$\begin{array}{l}\text { Fee } \\
\text { structure } \\
\text { used in } \\
\text { Case } \\
\text { Study III }\end{array}$} \\
\hline \multirow{2}{*}{$\begin{array}{l}\text { Oversize } \\
\text { Permit }\end{array}$} & \multirow{2}{*}{$\begin{array}{l}\text { Single } \\
\text { Trip } \\
90 \text { Day } \\
\text { Annual }\end{array}$} & \multirow{2}{*}{$\begin{array}{l}\text { M-233, Permit } \\
\text { M-233, Permit } \\
\text { M-233, Permit }\end{array}$} & \multirow{2}{*}{$\begin{array}{l}\text { \$20: up to } 95^{\prime} \text { in length, } 12^{\prime} 4^{\prime \prime} \text { wide } \\
\text { \& legal height } \\
\text { \$30: between } 96^{\prime} \text { and } 110^{\prime} \text { in length, } \\
12^{\prime} 5^{\prime \prime} \text { and } 16^{\prime} \text { wide or } 13^{\prime} 7^{\prime \prime} \text { and } 15^{\prime} \\
\text { tall } \\
\$ 40 \text { : over } 110^{\prime} \text { in length, } 16^{\prime} \text { wide, } \\
15^{\prime} \text { tall and } 80,000 \text { pounds }\end{array}$} & \multirow[t]{2}{*}{$\$ 100$} & \multirow[t]{2}{*}{$\$ 405$} & \\
\hline & & & & & & \\
\hline $\begin{array}{l}\text { Overweight } \\
\text { Permit }\end{array}$ & $\begin{array}{l}\text { Single } \\
\text { Trip (15 } \\
\text { Days) }\end{array}$ & M-233, Permit & $\begin{array}{l}\$ 20+\$ .35 \text { per mile for vehicles up } \\
\text { to } 108,000 \text { lbs. } \\
\star \$ 20+\$ .60 \text { per mile for vehicles } \\
\text { over } 108,000 \text { to } 150,000 \text { lbs. } \\
* \$ 20+\$ 1.00 \text { per mile for vehicles } \\
\text { over } 150,000 \text { lbs. }\end{array}$ & & & \\
\hline $\begin{array}{l}\text { Oversize \& } \\
\text { Overweight } \\
\text { Permit }\end{array}$ & $\begin{array}{c}\text { Single } \\
\text { Trip } \\
\text { (15 Days) }\end{array}$ & M-233, Permit & $\begin{array}{l}\text { Greater of the oversize or } \\
\text { overweight fee calculated above }\end{array}$ & & & \\
\hline $\begin{array}{l}\text { Special Weight } \\
\text { Permit }\end{array}$ & $\begin{array}{c}\text { Multiple } \\
\text { Trip (1 } \\
\text { Day) } \\
\text { Quarterly } \\
\text { billing } \\
\end{array}$ & $\begin{array}{l}\text { M-233ST, Permit } \\
\text { M-211, Registration } \\
\text { M-219, Bond Form }\end{array}$ & $\$ 42.50$ & & & \\
\hline $\begin{array}{l}\text { 12'4" Mobile } \\
\text { Home Rig } \\
\text { Permit }\end{array}$ & $\begin{array}{c}\text { Single } \\
\text { Trip (15 } \\
\text { Days) } \\
\text { Annual } \\
\text { Quarterly } \\
\text { Dealer's }\end{array}$ & $\begin{array}{l}\text { M-233, Permit } \\
\text { M-233DR, Permit }\end{array}$ & $\$ 10.00$ & $\$ 250.00$ & $\begin{array}{l}\$ 1000.00 \\
\$ 40.00 \text { for } \\
\text { dealers. }\end{array}$ & \\
\hline $\begin{array}{l}\text { 14'4" Mobile } \\
\text { Home Rig } \\
\text { Permit }\end{array}$ & $\begin{array}{c}\text { Single } \\
\text { Trip (5) } \\
\text { Days } \\
\text { Quarterly } \\
\text { Annual }\end{array}$ & M-233, Permit & $\$ 18.00$ & $\$ 500.00$ & $\$ 2000.00$ & \\
\hline $\begin{array}{l}\text { Toll Road Gate } \\
\text { Permit }\end{array}$ & Annual & M-233T, Permit & & & $\begin{array}{l}\$ 20 \text { per gate, } \\
\text { per truck. }\end{array}$ & \\
\hline
\end{tabular}

Source: Oversize-Overweight Vehicle Permitting Handbook, Permit Unit, Motor Carrier Services Division, Indiana Department of Revenue, Indianapolis, IN. http://www.in.gov/dor/files/osowhandbook.pdf

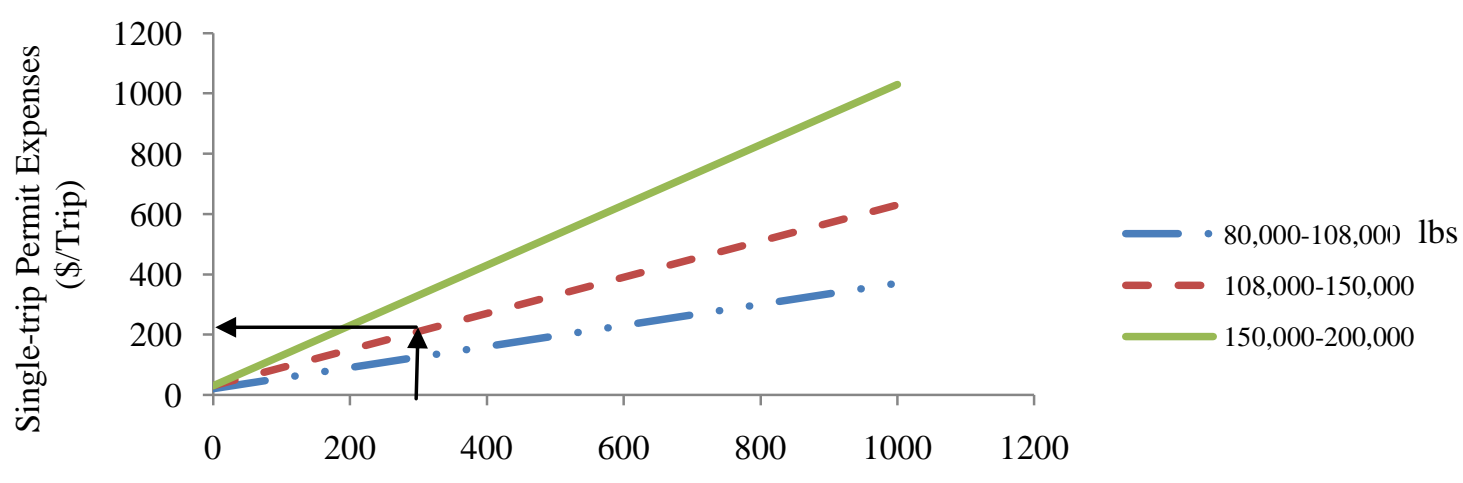

Truck Miles Traveled Per Trip (Miles)

Figure 5.3 Single-trip Permit Expenses vs. Truck-Miles Traveled, for Various OW Categories 
Table 5.15 Single-trip Permit Expenses vs. Truck Miles Traveled for Various OW Categories

\begin{tabular}{|c|c|c|c|}
\hline \multirow{2}{*}{$\begin{array}{l}\text { Truck Miles Traveled (VMT) (in } \\
\text { miles) }\end{array}$} & \multicolumn{3}{|c|}{$\begin{array}{c}\text { Single Permit Expenses (\$)/ Trip for } \\
\text { Various Categories of OW Trucks (GVW in lbs) }\end{array}$} \\
\hline & $80000-108,000$ & $108000-150,000$ & $150,000-200,000$ \\
\hline 0 & 20 & 30 & 30 \\
\hline 10 & 23.5 & 36 & 40 \\
\hline 25 & 28.75 & 45 & 55 \\
\hline 50 & 37.5 & 60 & 80 \\
\hline 75 & 46.25 & 75 & 105 \\
\hline 100 & 55 & 90 & 130 \\
\hline 125 & 63.75 & 105 & 155 \\
\hline 150 & 72.5 & 120 & 180 \\
\hline 175 & 81.25 & 135 & 205 \\
\hline 200 & 90 & 150 & 230 \\
\hline 225 & 98.75 & 165 & 255 \\
\hline 250 & 107.5 & 180 & 280 \\
\hline 275 & 116.25 & 195 & 305 \\
\hline 300 & 125 & 210 & 330 \\
\hline 325 & 133.75 & 225 & 355 \\
\hline 350 & 142.5 & 240 & 380 \\
\hline 375 & 151.25 & 255 & 405 \\
\hline 400 & 160 & 270 & 430 \\
\hline 425 & 168.75 & 285 & 455 \\
\hline 450 & 177.5 & 300 & 480 \\
\hline 475 & 186.25 & 315 & 505 \\
\hline 500 & 195 & 330 & 530 \\
\hline 750 & 282.5 & 480 & 780 \\
\hline 1000 & 370 & 630 & 1030 \\
\hline
\end{tabular}

\subsection{Case Study IV - Determining how much a hypothetical trucker should pay in each given year on the basis of damage done to pavement}

In this case study, we determine the appropriate pavement cost for a hypothetical trucker who wishes to manage 10,000 truck trips per year with $134,000 \mathrm{lbs}$ GVW, on the basis of the impact of these trips on the roadway pavement. In order to find a relationship between weight per axle and unit pavement cost, data provided in Table 5.16 were used to develop plots and establish models for Urban Interstate and Rural Interstate highways (as given in Figure 5.4). Data from Table 5.16 were processed and summarized to yield Table 5.17. 


\section{$\underline{\text { Unit Pavement Cost vs. Truck Miles Traveled }}$}

Table 5.16 presents the unit pavement cost for various truck types ( $\$ / 1000$ miles) (FHWA, 2000). Also, Table 5.17 presents the weight per axle vs. unit pavement cost ( $\$ / 1000$ miles), urban and rural interstates (Reference: Table 3.1 of this report).

Table 5.16 Unit Pavement Cost for Various Truck Types (FHWA, 2000)

\begin{tabular}{llcc}
\hline Vehicle Class & Interstate & $\begin{array}{c}\text { Unit Pavement Cos } \\
\text { (Cents per Mile) }\end{array}$ & $\begin{array}{c}\text { Unit Pavement Cost } \\
\text { (\$/1000 Miles) }\end{array}$ \\
\hline 40,000 4-axle Single Unit Truck & Rural & 1.0 & 10.0 \\
\hline 40,000 4-axle Single Unit Truck & Urban & 3.1 & 31.0 \\
\hline 60,000 4-axle Single Unit Truck & Rural & 5.6 & 56.0 \\
\hline 60,000 4-axle Single Unit Truck & Urban & 18.1 & 181.0 \\
\hline 60,000 5-axle Combination Truck & Rural & 3.3 & 33.0 \\
\hline 60,000 5-axle Combination Truck & Urban & 10.5 & 105.0 \\
\hline 80,000 5-axle Combination Truck & Rural & 12.7 & 127.0 \\
\hline 80,000 5-axle Combination Truck & Urban & 40.9 & 409.0 \\
\hline
\end{tabular}

Table 5.17 Weight per Axle vs. Unit Pavement Cost, Urban and Rural Interstates

\begin{tabular}{|c|c|c|c|c|}
\hline \multirow[t]{2}{*}{ Number of Axles } & \multirow[t]{2}{*}{ GVW (lbs) } & \multirow[t]{2}{*}{ Weight Per Axle (Ibs) } & \multicolumn{2}{|c|}{ Unit Pavement Cost (\$/1000 Miles) } \\
\hline & & & Rural & Urban \\
\hline (a) & (b) & $(b) \div(a)$ & & \\
\hline 4 & 40,000 & 10000 & 10.0 & 31.0 \\
\hline 4 & 60,000 & 15000 & 56.0 & 181.0 \\
\hline 5 & 60,000 & 12000 & 33.0 & 105.0 \\
\hline 5 & 80,000 & 16000 & 127.0 & 409.0 \\
\hline
\end{tabular}

Since it was required to find the unit pavement cost for various numbers of axles with given GVW of 134,000 lbs, the weight per axle was determined using the following equation: 
Using the developed models shown in Figure 5.4, the unit pavement cost per 1,000 miles was estimated for each set of axle number and for Urban and Rural Interstate (IS) Highways (Table 5.18). Also, using the unit pavement cost per 1,000 miles in Table 5.18, the pavement cost was calculated for different mile ranges (Tables 5.19 and 5.20).

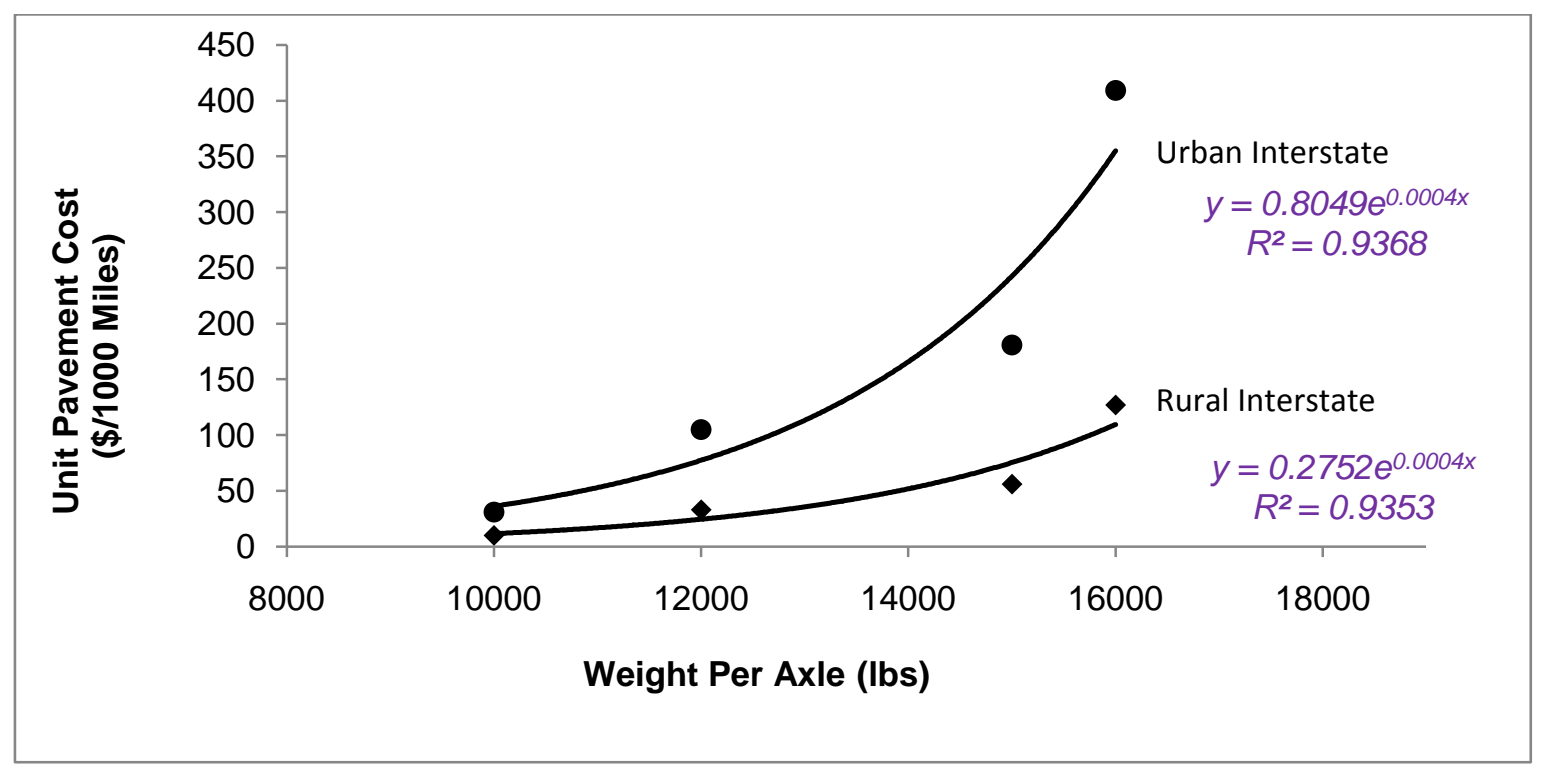

Figure 5.4 Weights per Axle vs. Unit Pavement Cost, Urban and Rural Interstates (Developed using data from FWHA, 2000), 134,000 lb GVW Truck

Table 5.18 Unit Pavement Cost, 134,000 lb GVW Truck

\begin{tabular}{ccccccc}
\hline \# of Axles & GVW(Ibs) & $\begin{array}{c}\text { Wt Per Axle } \\
\text { (Ibs) }\end{array}$ & \multicolumn{2}{c}{$\begin{array}{c}\text { Pavement Cost } \\
\text { (\$/1000 Miles) }\end{array}$} & \multicolumn{2}{c}{$\begin{array}{c}\text { Pavement Cost } \\
\text { (\$/ Miles) }\end{array}$} \\
\hline$(a)$ & $(b)$ & $(b) \div(a)$ & Rural IS & Urban IS & Rural IS & Urban IS \\
\hline 6 & 134,000 & 22333.33 & 2084.64 & 6101.54 & 2.08 & 6.10 \\
\hline 7 & 134,000 & 19142.86 & 581.82 & 1702.93 & 0.58 & 1.70 \\
\hline 8 & 134,000 & 16750.00 & 223.41 & 653.90 & 0.22 & 0.65 \\
\hline 9 & 134,000 & 14888.89 & 106.12 & 310.60 & 0.11 & 0.31 \\
\hline 10 & 134,000 & 13400.00 & 58.45 & 171.22 & 0.06 & 0.17 \\
\hline
\end{tabular}


Table 5.19 Unit Pavement Cost vs. Truck Miles Travelled for Urban and Rural Interstates (20 to 1000 Miles), Year 2000 constant dollars, 134,000 lb GVW Truck

\begin{tabular}{|c|c|c|c|c|c|c|c|c|c|c|}
\hline \multicolumn{11}{|c|}{ Unit Pavement Cost $(\$)$} \\
\hline \multirow[b]{3}{*}{$\begin{array}{l}\text { Distance } \\
\text { (miles) }\end{array}$} & \multirow{2}{*}{\multicolumn{5}{|c|}{$\begin{array}{l}\text { Urban IS } \\
\text { \# of Axles }\end{array}$}} & \multirow{2}{*}{\multicolumn{5}{|c|}{$\begin{array}{c}\text { Rural IS } \\
\text { \# of Axles }\end{array}$}} \\
\hline & & & & & & & & & & \\
\hline & 6 & 7 & 8 & 9 & 10 & 6 & 7 & 8 & 9 & 10 \\
\hline 20 & 122.03 & 34.06 & 13.08 & 6.21 & 3.42 & 41.69 & 11.64 & 4.47 & 2.12 & 1.17 \\
\hline 50 & 305.08 & 85.15 & 32.70 & 15.53 & 8.56 & 104.23 & 29.09 & 11.17 & 5.31 & 2.92 \\
\hline 75 & 457.62 & 127.72 & 49.04 & 23.30 & 12.84 & 156.35 & 43.64 & 16.76 & 7.96 & 4.39 \\
\hline 100 & 610.15 & 170.29 & 65.39 & 31.06 & 17.12 & 208.46 & 58.18 & 22.34 & 10.61 & 5.85 \\
\hline 200 & 1220.31 & 340.59 & 130.78 & 62.12 & 34.24 & 416.93 & 116.36 & 44.68 & 21.22 & 11.70 \\
\hline 300 & 1830.46 & 510.88 & 196.17 & 93.18 & 51.37 & 625.39 & 174.55 & 67.02 & 31.84 & 17.55 \\
\hline 400 & 2440.62 & 681.17 & 261.56 & 124.24 & 68.49 & 833.85 & 232.73 & 89.36 & 42.45 & 23.40 \\
\hline 500 & 3050.77 & 851.47 & 326.95 & 155.30 & 85.61 & 1042.32 & 290.91 & 111.71 & 53.06 & 29.25 \\
\hline 600 & 3660.92 & 1021.76 & 392.34 & 186.36 & 102.73 & 1250.78 & 349.09 & 134.05 & 63.67 & 35.10 \\
\hline 700 & 4271.08 & 1192.05 & 457.73 & 217.42 & 119.86 & 1459.24 & 407.27 & 156.39 & 74.28 & 40.95 \\
\hline 800 & 4881.23 & 1362.34 & 523.12 & 248.48 & 136.98 & 1667.71 & 465.45 & 178.73 & 84.90 & 46.80 \\
\hline 900 & 5491.38 & 1532.64 & 588.51 & 279.54 & 154.10 & 1876.17 & 523.64 & 201.07 & 95.51 & 52.65 \\
\hline 1000 & 6101.54 & 1702.93 & 653.91 & 310.60 & 171.22 & 2084.64 & 581.82 & 223.41 & 106.12 & 58.50 \\
\hline
\end{tabular}

Note: To obtain the cost in current dollars, apply the FHWA CPI adjustment factor.

Table 5.20 Unit Pavement Cost vs. Truck Miles Travelled for Urban and Rural Interstates (1000 to 30,000 Miles), Year 2000 constant dollars, 134,000 lb GVW Truck

\begin{tabular}{|c|c|c|c|c|c|c|c|c|c|c|}
\hline \multicolumn{11}{|c|}{ Unit Pavement Cost (\$) } \\
\hline \multirow[b]{3}{*}{$\begin{array}{c}\text { Distance } \\
\text { (miles) }\end{array}$} & \multirow{2}{*}{\multicolumn{5}{|c|}{$\begin{array}{c}\text { Urban IS } \\
\text { \# of Axles }\end{array}$}} & \multirow{2}{*}{\multicolumn{5}{|c|}{$\begin{array}{c}\text { Rural IS } \\
\text { \# of Axles }\end{array}$}} \\
\hline & & & & & & & & & & \\
\hline & 6 & 7 & 8 & 9 & 10 & 6 & 7 & 8 & 9 & 10 \\
\hline 1000 & 6102 & 1703 & 654 & 311 & 171 & 2085 & 582 & 223 & 106 & 58 \\
\hline 2000 & 12203 & 3406 & 1308 & 621 & 342 & 4169 & 1164 & 447 & 212 & 117 \\
\hline 5000 & 30508 & 8515 & 3270 & 1553 & 856 & 10423 & 2909 & 1117 & 531 & 292 \\
\hline 10000 & 61015 & 17029 & 6539 & 3106 & 1712 & 20846 & 5818 & 2234 & 1061 & 585 \\
\hline 15000 & 91523 & 25544 & 9809 & 4659 & 2568 & 31270 & 8727 & 3351 & 1592 & 877 \\
\hline 20000 & 122031 & 34059 & 13078 & 6212 & 3424 & 41693 & 11636 & 4468 & 2122 & 1170 \\
\hline 25000 & 152538 & 42573 & 16348 & 7765 & 4281 & 52116 & 14545 & 5585 & 2653 & 1462 \\
\hline 30000 & 183046 & 51088 & 19617 & 9318 & 5137 & 62539 & 17455 & 6702 & 3184 & 1755 \\
\hline
\end{tabular}

Note: To obtain the cost in current dollars, apply the FHWA CPI adjustment factor. 
Table 5.21 Unit Pavement Cost vs. Truck Miles Travelled for Urban and Rural Interstates (20 to 1000 Miles), Year 2010 constant dollars, 134,000 lb GVW Truck

\begin{tabular}{|c|c|c|c|c|c|c|c|c|c|c|}
\hline \multicolumn{11}{|c|}{ Unit Pavement Cost (\$) } \\
\hline & \multicolumn{5}{|c|}{ Urban IS } & \multicolumn{5}{|c|}{ Rural IS } \\
\hline & \multicolumn{5}{|c|}{ \# of Axles } & \multicolumn{5}{|c|}{ \# of Axles } \\
\hline $\begin{array}{l}\text { Distance } \\
\text { (miles) }\end{array}$ & 6 & 7 & 8 & 9 & 10 & 6 & 7 & 8 & 9 & 10 \\
\hline 20 & 183.20 & 51.13 & 19.63 & 9.33 & 5.14 & 62.59 & 17.47 & 6.71 & 3.19 & 1.76 \\
\hline 50 & 457.99 & 127.82 & 49.08 & 23.31 & 12.85 & 156.48 & 43.67 & 16.77 & 7.97 & 4.39 \\
\hline 75 & 686.98 & 191.74 & 73.62 & 34.97 & 19.28 & 234.71 & 65.51 & 25.15 & 11.95 & 6.59 \\
\hline 100 & 915.98 & 255.65 & 98.17 & 46.63 & 25.70 & 312.95 & 87.34 & 33.54 & 15.93 & 8.78 \\
\hline 200 & 1831.95 & 511.30 & 196.33 & 93.26 & 51.41 & 625.90 & 174.69 & 67.08 & 31.86 & 17.56 \\
\hline 300 & 2747.93 & 766.94 & 294.50 & 139.89 & 77.11 & 938.85 & 262.03 & 100.62 & 47.79 & 26.35 \\
\hline 400 & 3663.91 & 1022.59 & 392.66 & 186.51 & 102.82 & 1251.80 & 349.38 & 134.16 & 63.72 & 35.13 \\
\hline 500 & 4579.88 & 1278.24 & 490.83 & 233.14 & 128.52 & 1564.75 & 436.72 & 167.70 & 79.65 & 43.91 \\
\hline 600 & 5495.86 & 1533.89 & 588.99 & 279.77 & 154.23 & 1877.70 & 524.06 & 201.23 & 95.59 & 52.69 \\
\hline 700 & 6411.84 & 1789.53 & 687.16 & 326.40 & 179.93 & 2190.65 & 611.41 & 234.77 & 111.52 & 61.47 \\
\hline 800 & 7327.81 & 2045.18 & 785.33 & 373.03 & 205.63 & 2503.60 & 698.75 & 268.31 & 127.45 & 70.26 \\
\hline 900 & 8243.79 & 2300.83 & 883.49 & 419.66 & 231.34 & 2816.55 & 786.10 & 301.85 & 143.38 & 79.04 \\
\hline 1000 & 9159.77 & 2556.48 & 981.66 & 466.29 & 257.04 & 3129.50 & 873.44 & 335.39 & 159.31 & 87.82 \\
\hline
\end{tabular}

Note: To obtain the cost in current dollars, apply the FHWA CPI adjustment factor.

Table 5.22 Unit Pavement Cost vs. Truck Miles Travelled for Urban and Rural Interstates (1000 to 30,000 Miles), Year 2010 constant dollars, 134,000 lb GVW Truck

\begin{tabular}{|c|c|c|c|c|c|c|c|c|c|c|}
\hline \multicolumn{10}{|c|}{ Urban IS } \\
\hline & \multicolumn{9}{|c|}{ \# of Axles } & \multicolumn{5}{c|}{ Rural IS } \\
\hline & \multicolumn{9}{|c|}{ \# of Axles } \\
\hline $\begin{array}{c}\text { Distance } \\
\text { (miles) }\end{array}$ & $\mathbf{6}$ & $\mathbf{7}$ & $\mathbf{8}$ & $\mathbf{9}$ & $\mathbf{1 0}$ & $\mathbf{6}$ & $\mathbf{7}$ & $\mathbf{8}$ & $\mathbf{9}$ & $\mathbf{1 0}$ \\
\hline 1000 & 9160 & 2556 & 982 & 466 & 257 & 3130 & 873 & 335 & 159 & 88 \\
\hline 2000 & 18320 & 5113 & 1963 & 933 & 514 & 6259 & 1747 & 671 & 319 & 176 \\
\hline 5000 & 45799 & 12782 & 4908 & 2331 & 1285 & 15648 & 4367 & 1677 & 797 & 439 \\
\hline 10000 & 91598 & 25565 & 9817 & 4663 & 2570 & 31295 & 8734 & 3354 & 1593 & 878 \\
\hline 15000 & 137396 & 38347 & 14725 & 6994 & 3856 & 46943 & 13102 & 5031 & 2390 & 1317 \\
\hline 20000 & 183195 & 51130 & 19633 & 9326 & 5141 & 62590 & 17469 & 6708 & 3186 & 1756 \\
\hline 25000 & 228994 & 63912 & 24541 & 11657 & 6426 & 78238 & 21836 & 8385 & 3983 & 2196 \\
\hline 30000 & 274793 & 76694 & 29450 & 13989 & 7711 & 93885 & 26203 & 10062 & 4779 & 2635 \\
\hline
\end{tabular}




\subsubsection{Illustration of Calculations}

Assumption: the hypothetical trucker uses only Rural Interstate Highways

$\mathrm{GVW}=134,000 \mathrm{lbs}$

Number of axles considered $=6$

Weight $(\mathrm{Wt})$ per axle $=134,000 \mathrm{lbs} \div 6=22,333.33 \mathrm{lbs}$ per axle (highlighted in Table 5.18)

Therefore,

Unit Pavement Cost per 1000 Truck Miles (with 2233.33 lbs per axle) on Rural Interstate highways $=$ (highlighted in Table 5.18)

This amount is based on the dollar value as of the year of the FHWA (2000) report. Thus, applying the FHWA CPI adjustment factor, this corresponds to ( $* 213.3 / 145.6)=\$ 3,056.2$ in year 2009 constant dollar.

Calculations of Pavement Costs for Rural Interstate

10,000 truck-miles $=\$ 3056.2 * 10=\$ 30,562$

10,000 truck-trips $(1$-mile per trip) $=\$ 30,562$

10,000 truck-trips $(10$-miles per trip) $=\$ 305,620$

10,000 truck-trips (100-mile per trip) $=\mathbf{\$ 3 , 0 5 6 , 2 0 0}$

Similarly, the pavement cost due to 10,000 trucks-trips (for any number of miles traveled per trip), can be determined.

Further, the pavement cost corresponding to any number of trucks trips (and any number of miles traveled per trip), can be determined.

Assume that the trucks have adjustable number of axles. Then it is useful to present calculations for other axle numbers (that is, from 7-axle to 10 axle in 1 axle increments), knowing the highway class, and truck miles traveled. These were carried out and are presented in Tables 5.18 to 5.20). From these tables, pavement cost nomographs were determined. These are presented as Figures 5.5 to 5.12 .

Using Figures 5.5 to 5.8, the analyst can determine, for a given number of axles, the unit pavement cost for different number of truck miles travelled, for urban and rural highways. Also, using Figures 5.8 to 5.10 , the analyst can determine, for a given number of truck miles traveled, the unit pavement cost for different number of axles, for urban and rural highways.

\section{Example Use of the Nomographs:}

For a 134,000 lb GVW, 10-axle truck that travels 300 miles on an urban interstate highway, the pavement damage cost is approximately $\$ 50$ (from Figure 5.5). The exact value may be found in Table 5.19. However, if the truck has only 6-axles, the pavement damage cost is approximately $\$ 2,000$ (from Figure 5.5). 


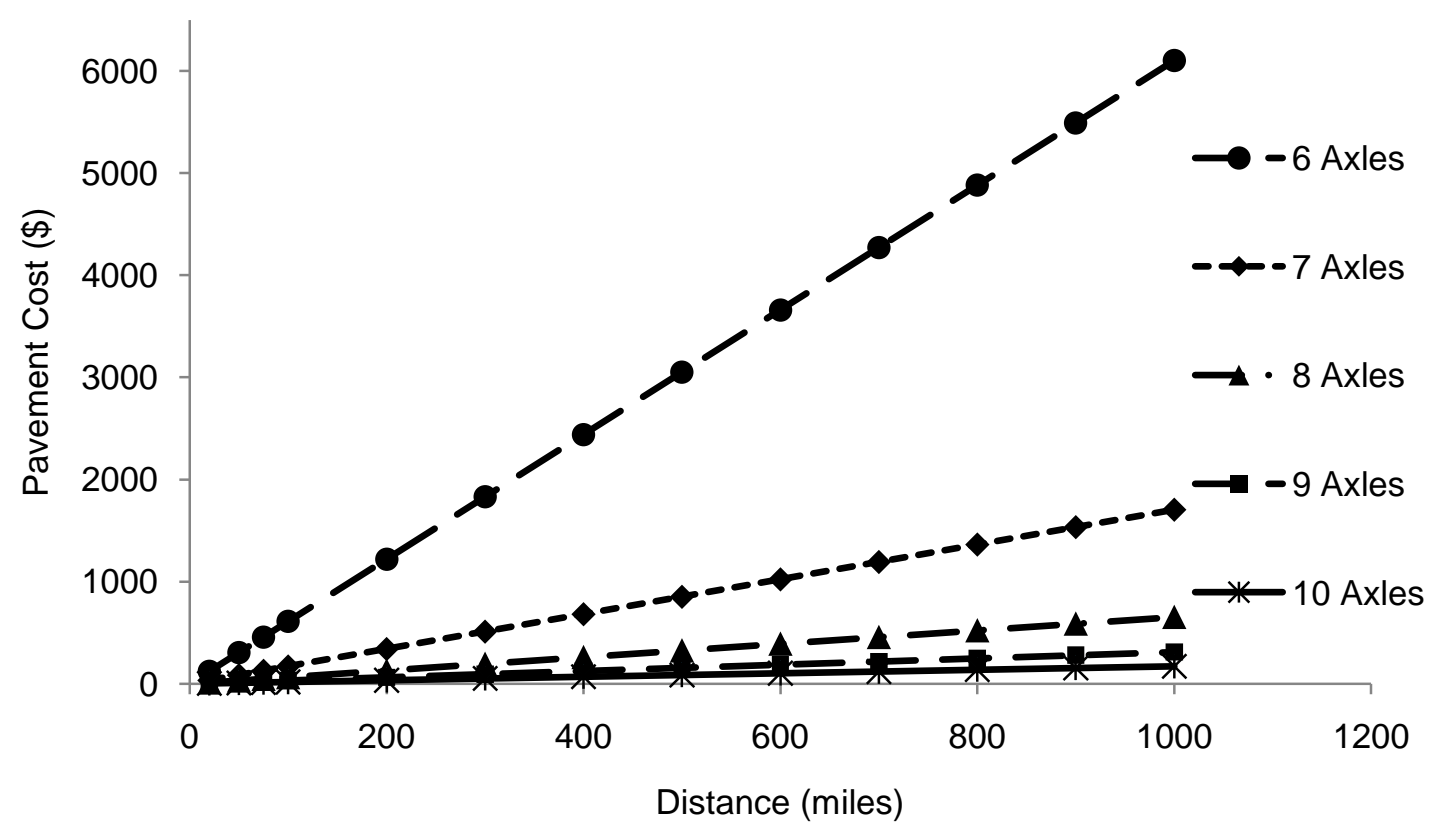

Figure 5.5 Unit Pavement Cost vs. Truck Miles Travelled for Urban Interstate Highways (0 to 1,000 Miles), 134,000 lb GVW Truck

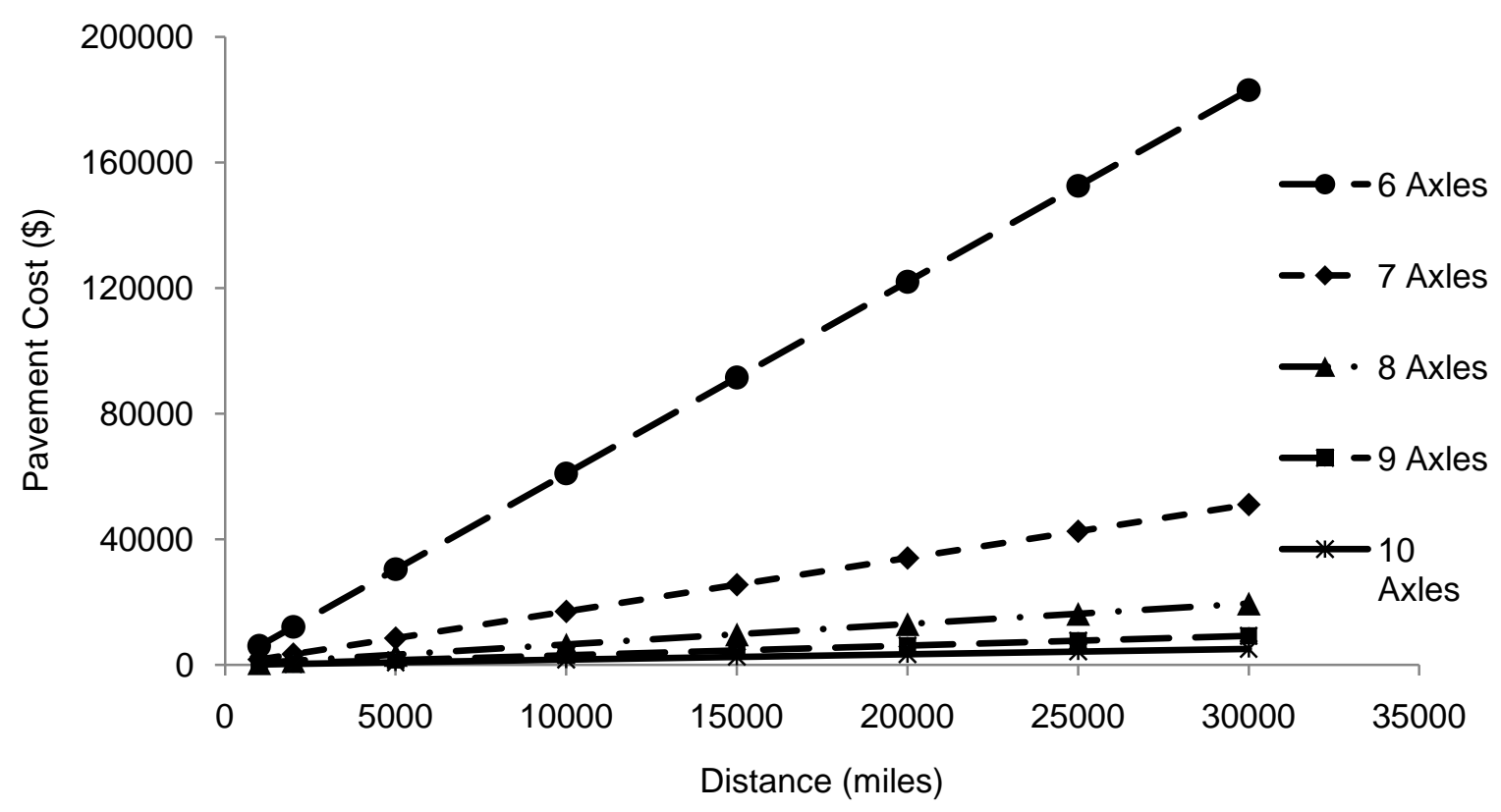

Figure 5.6 Unit Pavement Cost vs. Truck Miles Travelled for Urban Interstate Highways (1,000 to 30,000 Miles), 134,000 lb GVW Truck 


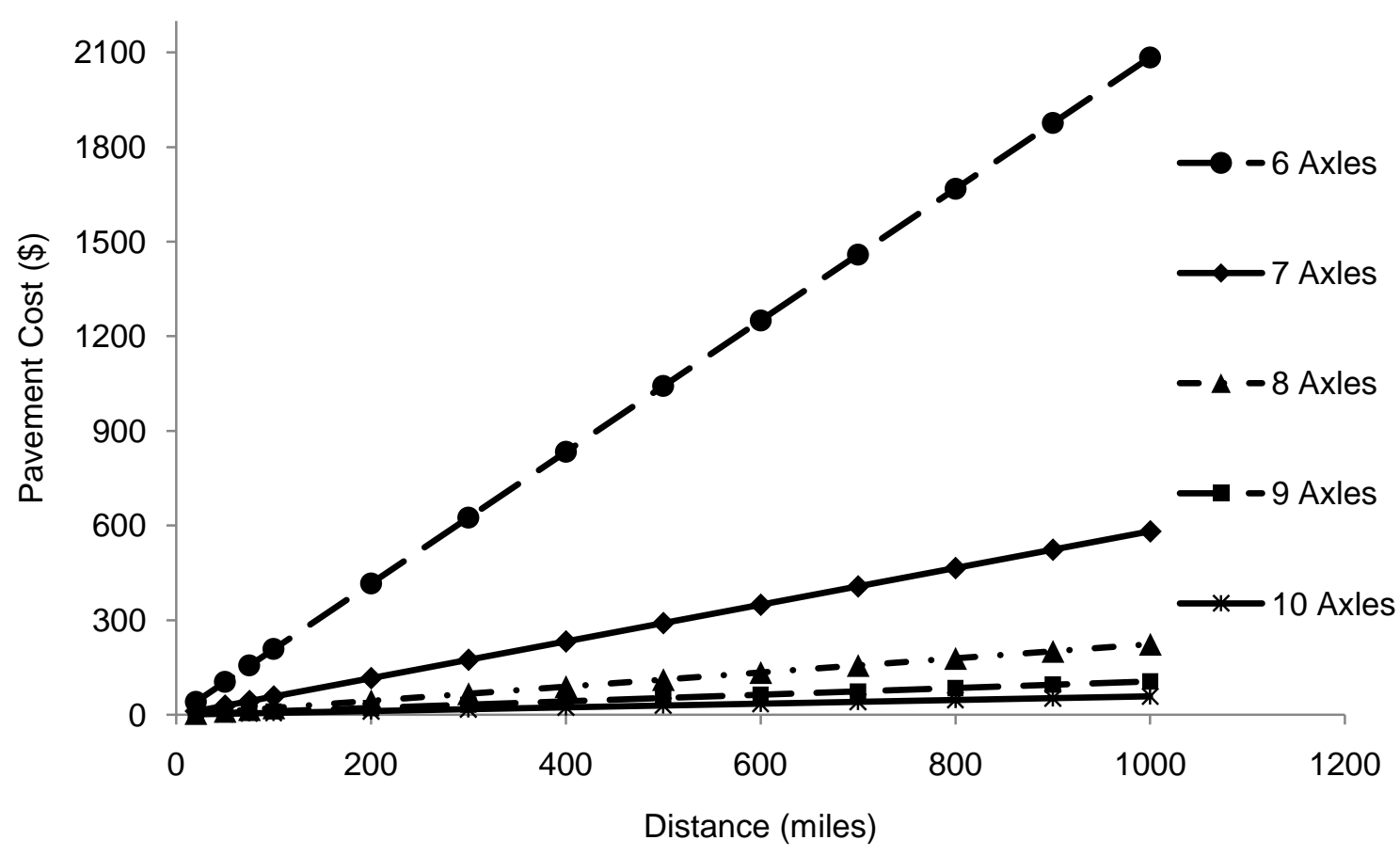

Figure 5.7 Unit Pavement Cost vs. Truck Miles Travelled for Rural Interstate Highways (0 to 1,000 Miles), 134,000 lb GVW Truck

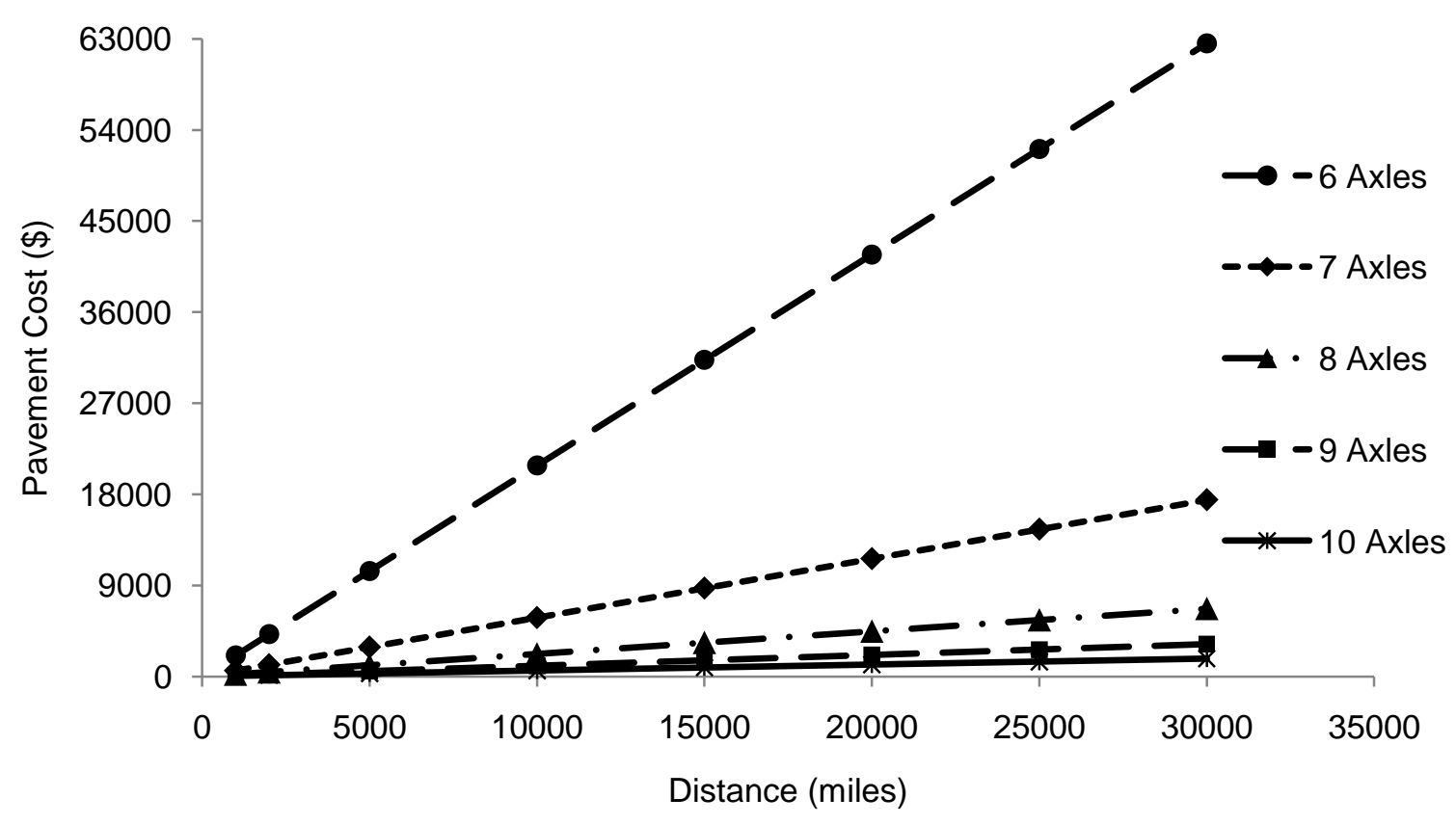

Figure 5.8 Unit Pavement Cost vs. Truck Miles Travelled for Rural Interstate Highways (1,000 to 30,000 Miles), 134,000 lb GVW Truck 


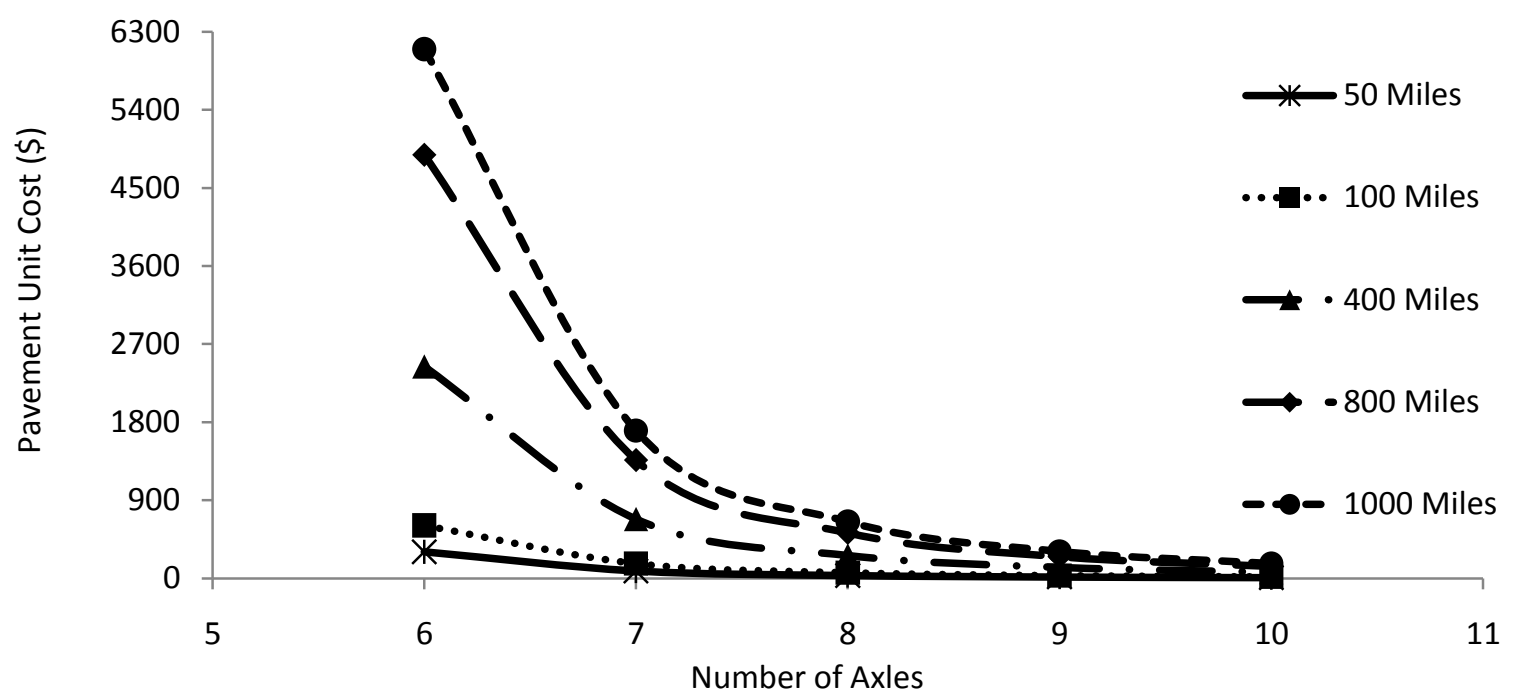

Figure 5.9 Unit Pavement Cost vs. Number of Axles for Urban Interstate Highways (0 to 1,000 Miles), 134,000 lb GVW Truck

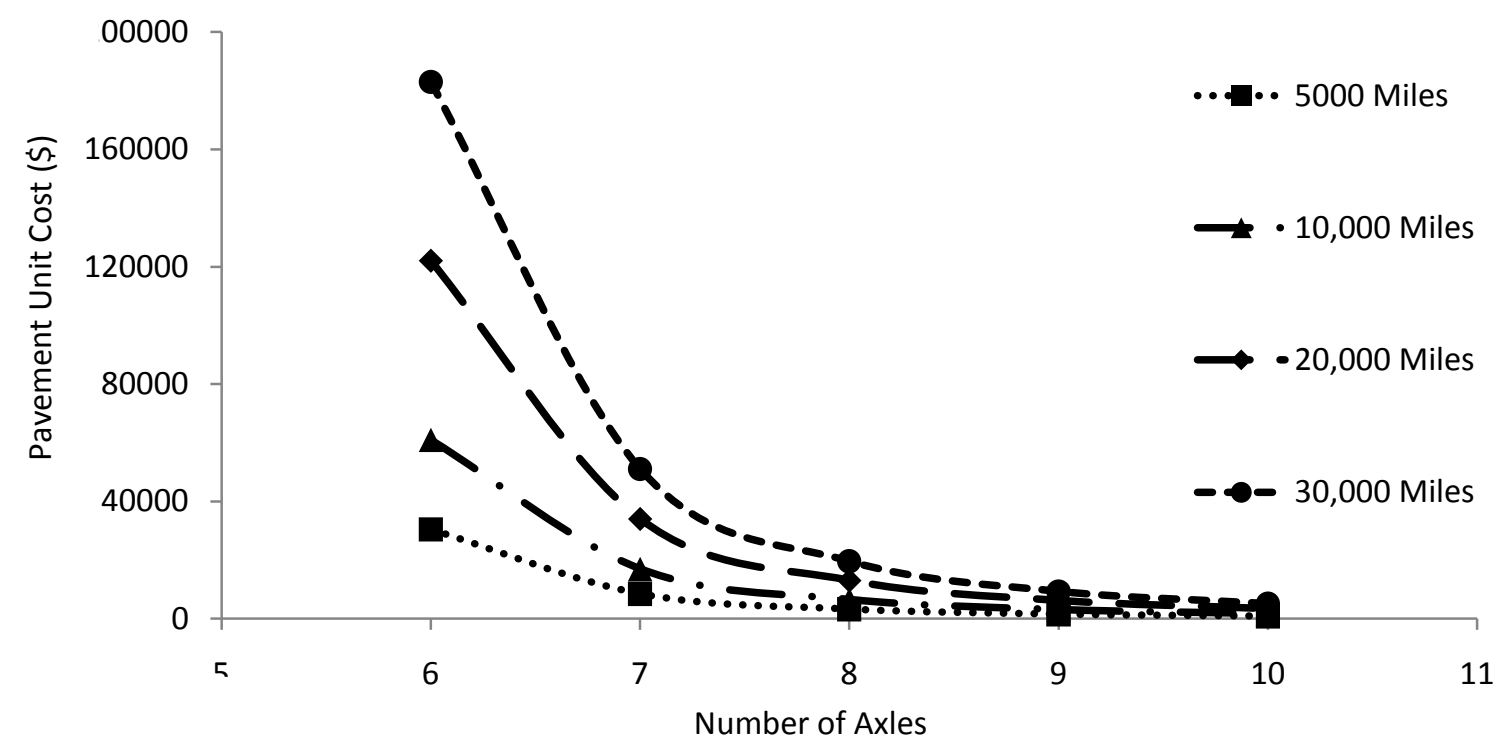

Figure 5.10 Unit Pavement Cost vs. Number of Axles for Urban Interstate Highways (Up to to 30,000 Miles), 134,000 lb GVW Truck 


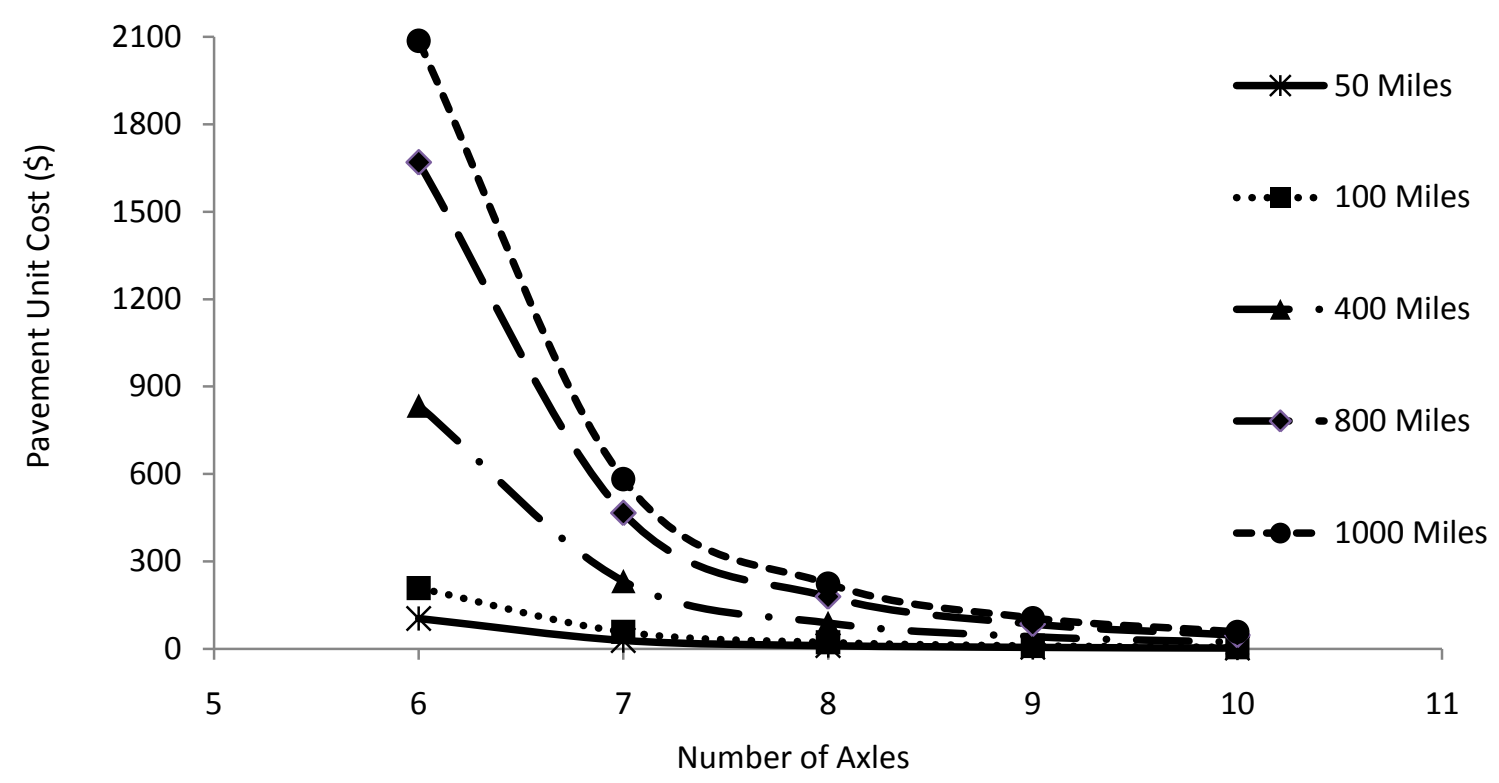

Figure 5.11 Unit Pavement Cost vs. Number of Axles for Rural Interstate Highways (0 to 1,000 Miles), 134,000 lb GVW Truck

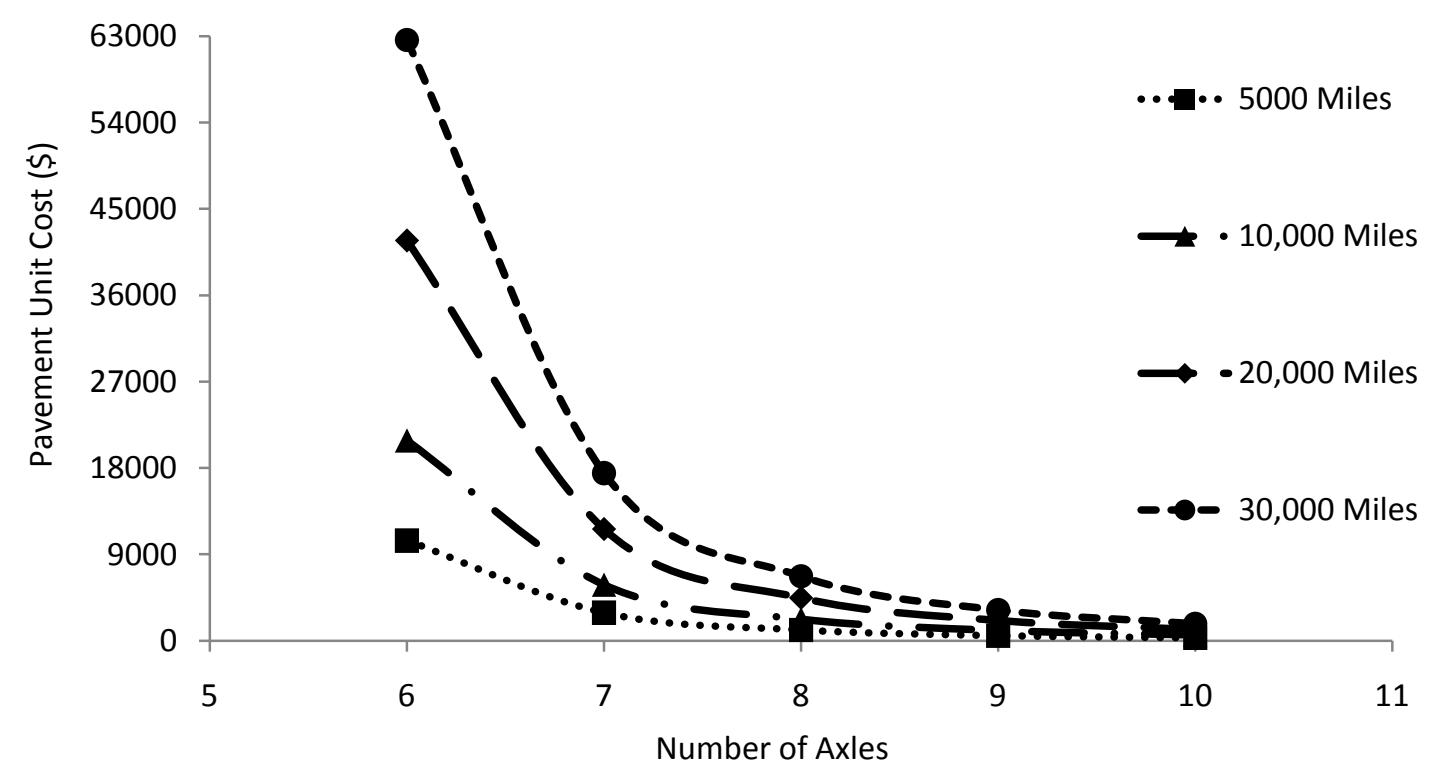

Figure 5.12 Unit Pavement Cost vs. Number of Axles for Rural Interstate Highways (up to 30,000 Miles), 134,000 lb GVW Truck 


\subsubsection{Comments}

1. Increase in number of axles causes a decrease in load per axle.

2. Pavement cost (for a given number of axles) increases (linearly) with increase in truck-miles traveled (Figures 5.5 to 5.8 ).

3. Pavement damage cost decreases drastically with increase in number of axles for a given traveled distance/ number of miles in a non-linear fashion (Figures 5.9 to 5.12).

Also from the case studies, it is interesting to observe that:

(i) At states with a blanket annual permit, the permit fee is far lower than states without a blanket annual permit; for the latter group of states, annual permit expenditure is a sum of multiple single trips;

(ii) For the hypothetical trucker (having a fleet shown in Table 5.1), relatively little total annual permit expenditure is incurred if the trucker operates at states that have a blanket annual permit; on the other hand, the trucker incurs relatively high expenditure at states that lack a blanket permit and thus for which the annualized trucker expenditure is calculated as an accumulated sum of multiple single-trip permit fees. This result suggests that adoption of an annual blanket fee may be unfavorable from the perspective of revenue generation. This is consistent not only with the findings of the Texas DOT but also with the admonitions of Moffett and Whitford;

(iii) As seen in point (ii) above, for blanket annual permit structures, total annual expenditure (by the trucker) and hence, revenue to the agency, and very low. Thus such revenue cannot be realistically expected to cover the corresponding damage to the pavement structure. At these states that have a blanket annual permit policy for overweight trucks, it is not certain whether the agencies are unwilling or unable (for reasons that may include political pressure) to increase these fees to more realistic levels.

For overweight trucks, INDOT is among the states that lack an annual blanket permit. However, the opportunity exists for INDOT and INDOR to issue special blanket permits to "favored" clients. These include industries and truckers who undertake a large number of OW trips and for whom seeking permits for each trip would be time consuming, laborious, and disruptive to their operations. It is the recommendation of this report that the state can deal with such truckers on a case-by-case basis. 


\section{CHAPTER 6: SUMMARY, CONCLUSIONS, AND DIRECTIONS FOR FUTURE RESEARCH}

\subsection{Summary}

This study was carried out to establish an enhanced and updated understanding of the state of practice on the truck weight permitting process in Indiana, in relation to that of neighboring states. The truck permitting practices and policies of eight Midwest states were documented, assessed, and compared on the basis of the ease of the permitting process for the permit applicant; the permit fee amounts; and the permit fee structure or basis for fees (per vehicle, per vehicle-mile, per to-mile, etc.). Also, using data from other state and national studies, the report develops charts that quantifies the extent to which every ton increase in payload increases the pavement deterioration and subsequent repair costs; the extent to which reduction (or addition) of axles increases (or reduces) the costs of pavement deterioration and how this could influence policies for payload increases (at states that have permitting thresholds per axle and not for gross weights).

The study report also presents the revenue streams obtained from the permits issued for extralegal trucking operations in Indiana and reports that the approximate amount obtained is approximately $\$ 12$ million per year. Obviously, this amount falls far short of what is needed to offset the cost of pavement damage due to overweight trucks even without including the cost of reduced safety and mobility due to oversize vehicle operations. However, a definitive assessment and conclusion can only be made after a detailed cost allocation study using data from Indiana.

The study product is intended to help in reviewing and documenting the state of practice in Indiana, from various perspectives including permitting structures and fees, pavement damage cost and cost allocation in the form of appropriate license and permit fees, and revenue generation. Generally, the study results are expected to provide a knowledge base for INDOT as that agency moves forward to update or streamline its permitting processes. The ultimate intention is to help the state preserve its investments in highway infrastructure without sacrificing the competitive position of the state in attracting and retaining entities that foster economic development. 


\subsection{Conclusions}

The study determined that while the upper thresholds (dimensions and weights) for extra-legal trucking operations are generally the same for each state, the upper thresholds for extra-legal operations vary considerably across the states, and in some cases, some states seem to have no limit on weights. Also, the findings from the internet search and phone interviews show that there is a great deal of variability in the criteria for truck permitting practices at various states and these criteria include extent to which a truck's weight or size attributes (length, width, height) is in excess of legal limits; distance traveled, type of commodity carried, and axle spacing. Furthermore, it was seen that no state has adopted explicitly the weight-distance concept for its overweight or oversize trucks. However, in the states of Indiana, Ohio, and Illinois, the fee structures for overweight vehicles includes weight levels and extents of travel and thus are similar to a weight-distance fee structure. The study also discussed briefly the issue of revenue neutrality: highway agencies that have switched from a single-trip permit system to an annual permit system report that they benefited from cost savings due to reduced monitoring efforts of each single trip but lost significant revenue overall.

From the case studies, it is observed that at states with a blanket annual permit, the permit fee is very low and cannot be realistically expected to generate adequate revenue. It is not certain whether the agencies at these states are unwilling or unable (for reasons that may include political pressure) to increase these fees to more realistic levels. In this regard, it was also observed that for the hypothetical trucker (having a fleet of a certain distribution), relatively little total annual permit expenditure is incurred if the trucker operates at states that have a blanket annual permit; on the other hand, the trucker incurs relatively high expenditure at states that lack a blanket permit and thus for which the annualized trucker expenditure is calculated as an accumulated sum of multiple single-trip permit fees. This result suggests that adoption of an annual blanket fee may be unfavorable from the perspective of revenue generation. This is consistent not only with the findings of the Texas DOT but also with the admonitions of Moffett and Whitford (1994). However, the opportunity exists for INDOT and INDOR to issue special blanket permits to "favored" clients. These include industries and truckers who undertake a large number of OW trips and for whom seeking permits for each trip would be time consuming, laborious, and disruptive to their operations. It is the recommendation of this report that the state can deal with such truckers on a case-by-case basis.

From the perspective of overweight and oversize thresholds and associated permit fees, it was observed that certain states appear to be generally most favorable to trucking because they have relatively high or nonexistent maximum-weight thresholds for defining what a superload is and relatively lower fees for overweight trucks. However, it is important to consider other permitting 
criteria as well in order to make a general and holistic assessment of this issue. The study shows that due to the peculiarities and nuances across the permitting structures across the states, a case-by-case analysis is the preferred way to compare the permit structures and fees across the states.

Using data from past national and state studies, the report presents a framework by which INDOT could develop nomographs to assess the increase in pavement costs for every ton increase in payload or the decrease in pavement costs for every increase in the number of axles, for any given truck class. This framework has been implemented in this report to develop nomographs for trucks of GVW 134,000lbs. However, it is to be noted that these pavement damage costs are based on past data at other states. There is therefore a need to update these costs to reflect conditions and data from Indiana at the current time. The study also concludes that using data from these studies, it is possible for INDOT to quantify the extent to which the reduction (or addition) of axles (due to, for example, lowering of auxiliary axles by a flexible axle truck, as shown in Figure 6.1) increases (or reduces) pavement deterioration and increases (or reduces) pavement damage cost.

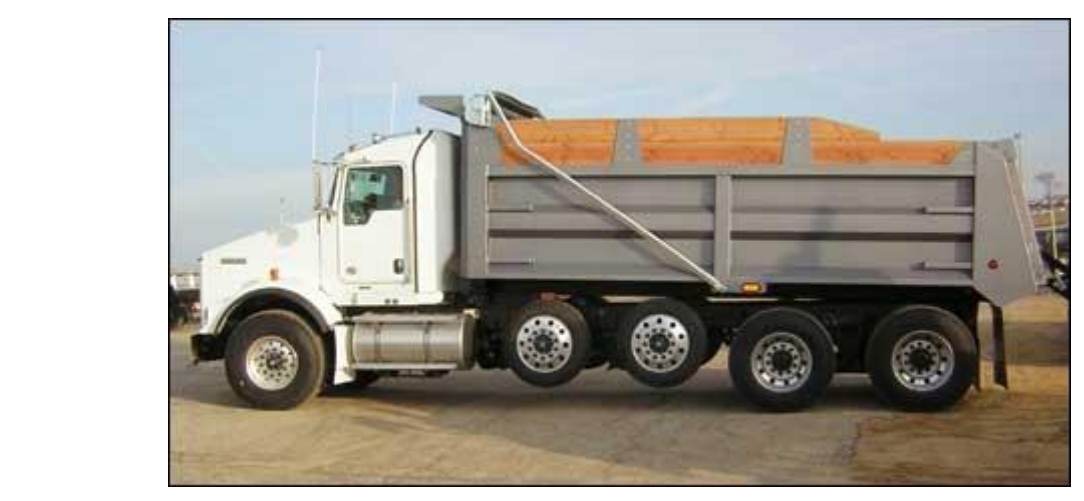

Figure 6.1: Example of a Lift-Axle Truck (Often the number of operational axles can be increased by lowering extra axles). [Image source: www.monroetruck.com]

\subsection{Future Research}

The conduction of this research opens up a number of directions for future research.

- Direct survey of the end users. It may be argued that the complications of the comparative process in this report could be avoided due to differences in permit structures across the states, on the premise that only the end product needs to be evaluated. The end product, in this case, would be the level of truckers' satisfaction with the permit policies at each state. Thus a questionnaire survey could be administered to gage such perspectives of the truckers) of the permit policies at each state. The Indiana Department of Revenue maintains a database 
containing the list of permit-using truckers that operate in Indiana. A sample of these truckers could be selected and the list could be narrowed down to include only those that also operate in at least one other state. The questionnaire could gage not only their overall satisfaction but also their perspectives on individual specific attributes of the permit process (fee structure complexity, fee levels, difficulty of securing permits, road conditions, etc.).

- Pavement cost attribution. For assessing the implications of increasing or decreasing axle loads on pavement damage costs, this report utilizes data from past state and national studies. Future research could use purely Indiana data at the current time to update these cost values. Specifically, a new cost allocation study is needed to update the last (1988) Indiana Cost Allocation study. Such a future study would help restructure fees for legal operations (license fees) and extra-legal operations (permits) to provide an optimal balance between pavement damage and revenues.

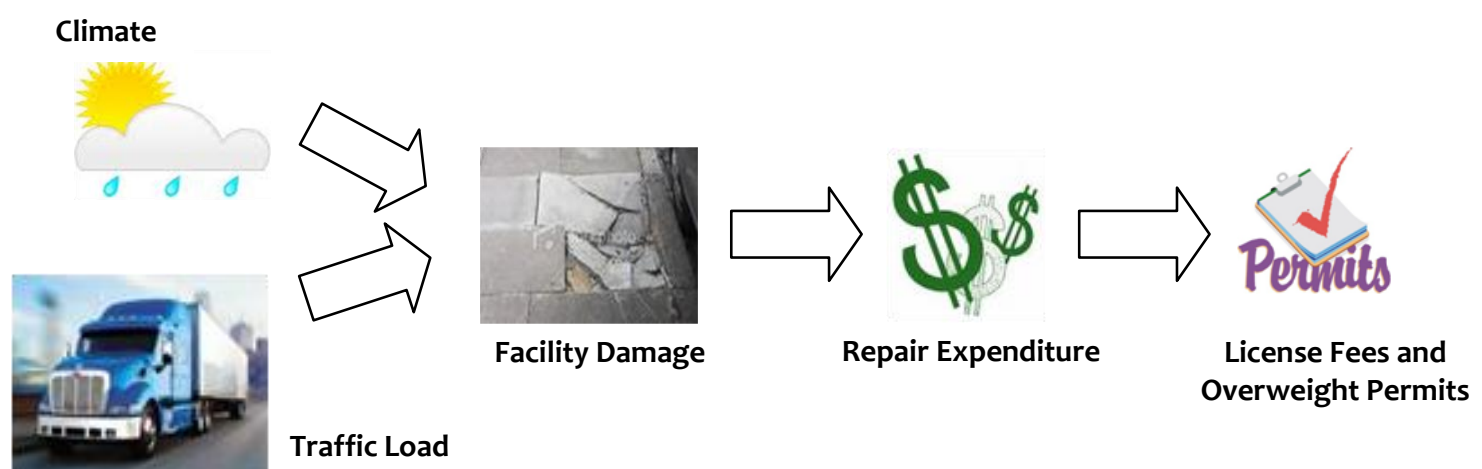

In a future cost allocation study (to be possibly sequenced as shown in the figure above), it should be duly recognized that not all damage is due to traffic load, and that climate too plays a role because solar oxidation, precipitation, freezing and freeze-thaw transitions also play a role in the material degradation. The split between load and climate depends on facility type and material types, for example, $28-72 \%$ for flexible pavements. The proposed cost allocation study would need to identify the deterioration due to load before fairly allocating fees and permits.

- Focus on relevant infrastructure. The overweight and oversize trucks often apply for permits to use certain stretches of highway only. The Indiana Department of Revenue possesses a 6,000-page document that lists all such roads. It would be beneficial to identify the road section that are involved, their respective frequencies of permit requests, and the loads requested for (average, maximums) over a 5- or 10-year period, and place such information 
on a GIS platform, for monitoring purposes. Further, such information would be useful for identifying stretches of highway that should receive higher priority for rehabilitation or reconstruction in the overall state highway improvement program.

- Route allocations. Consistent with the previous point, it is suggested, through future research, to establish an internet-accessible color-coded scheme that shows the specific routes whose location and other issues can be accessed by OW/OS truckers. This would facilitate the identification of permitted routes for the benefit and convenience of the trucking industry.

- Resolving the "Revenue vs. Cost" Conundrum. As pointed out in a Texas study, the revenue collected from permit fees are far inadequate to cover the cost of damage done by the overweight vehicles. It is worthwhile to carry out a study to ascertain the extent to which this is true in Indiana. This would serve as a basis for updating the permit fee structures, not necessarily to increase the overall fee, but to introduce greater equity in the permit structure. This can be addressed in a future cost allocation study.

- Changing thresholds over time. For a given pavement or bridge in its newly constructed state, the impact of an overweight truck may not be deleterious. However, for that same infrastructure in its advanced age at a future date, overweight truck loads could be particularly damaging because the pavement or bridge has experienced some deterioration and thus is less resilient to external stress. Thus, the overweight thresholds could be considered as dynamic rather than static. For dynamic permitting schemes to work properly, pavement and bridge engineers will need to continually monitor the health of highway assets through regular deflection measurements and load ratings, for example, or to update these indicators of structural condition using appropriate empirical models.

- Permitfee tie-in to infrastructure condition. Pursuant to the previous point, permit fees could be increased or decreased depending on the condition (or age) of the infrastructure. Note that the deterioration of infrastructure is not linear but starts gently in early life, accelerates sharply in mid-life, and tapers off gently in old age. As such, lower fees could be charged when the facility is in the middle age and higher fees when it is in its old age. Undoubtedly, such a dynamic pricing scheme could add complexity to the permit fee structure.

- Axle weights vs. GVW. Issuance of permits on the basis of axle weights instead of gross vehicle weights would mean a drastic overhaul of the permitting system in Indiana. However, this practice may very well add greater equity to the system, allow trucks to carry greater weights, reduce pavement damage, and yield greater revenue at the same time. Research is therefore needed to determine the appropriate amounts to charge if this system were adopted 
by the state, and also to assess the consequences of such a new system in terms of the revenue and pavement damage costs.

- Compliance Monitoring. The current truck monitoring system based on blue tooth technology only monitors the location or distance travelled but does not provide information on the number of axles or weights at a given time and location, and thus does not identify instances of weight violations particularly those committed by flexible-axle trucks that raise their axles. Future research will be needed to address this issue so that INDOT and INDOR are provided a mechanism to properly monitor the movements and intensities of extra-legal vehicles on a real-time or at least, near real-time basis.

- Assessing increases in agency cost. Changes in truck OW/OS permitting could translate into additional costs of monitoring, such as the purchase of new equipment and administration costs associated with new procedures, recruitment of new technical persons, purchase of new software packages. Future research could establish the extent of such cost increases that would be expected as a result of the implementation of the different possible permit structures. 


\section{REFERENCES AND RESOURCES}

\section{Indiana}

MCSD-INDOR (2006), Indiana Oversize/Overweight Permitting System - Final Report and User Manual, Permit Unit, Motor Carrier Services Division, Indiana Department of Revenue, Indianapolis, IN. http://www.in.gov/dor/files/osw-manual.pdf , Accessed August 16, 2009.

MCSD-INDOR (2009A), Oversize-Overweight Vehicle Permitting Handbook, Permit Unit, Motor Carrier Services Division, Indiana Department of Revenue, Indianapolis, IN.

http://www.in.gov/dor/files/osowhandbook.pdf , Accessed September 15, 2009.

\section{Michigan}

MDOT (2009A). Moving Oversize or Overweight Vehicles and Loads - Rules and Guidelines, Truckers Services Webpage, Michigan Department of Transportation, Lansing, MI.

http://www.michigan.gov/documents/MDOT MoveOS OW T2 92127 7.pdf , Accessed August 16, 2009.

MDOT (2009B). Maximum Legal Truck Loadings and Dimensions - Rules and Guidelines, Truckers Services Webpage,

$\begin{aligned} & \text { Michigan } \\ & \text { http://www.michigan.gov/documents/Loads_dim_87014_7.pdf, }\end{aligned}$, Accessed August 162009.

\section{Illinois}

IIDOT (2009). Informational Forms, IDOT Oversize/Overweight Permit Office, Springfield IL. http://www.dot.il.gov/road/infoforms.html, Accessed August 16, 2009.

\section{Ohio}

ODOT (2009). Special Hauling Permits Section (Oversize/Overweight Vehicles and Loads). Ohio Department of Transportation, Columbus, $\mathrm{OH}$, http://www.dot.state.oh.us/Divisions/HighwayOps/Maintenance/Permits/Pages/default.aspx

Accessed August 16, 2009.

\section{Wisconsin}

WisDOT (2009). Oversize-overweight permits, Wisconsin Department of Transportation, Madison, WI.

http://www.dot.wisconsin.gov/business/carriers/osowgeneral.htm, Accessed August 16, 2009.

\section{Iowa}

Iowa DOT (2009). Truck Information Guide 2008-2009 Edition, Office of Motor Carrier Services and Office of Motor Vehicle Enforcement, Iowa Department of Transportation, Des Moines, IA. http://www.iamvd.com/omve/truckguide.pdf, Accessed August 16, 2009.

\section{Kentucky}

KTC (2009A), Overweight/Overdimensional Section, Division of Motor Carriers, Kentucky Transportation Cabinet, Lexington, KY.

\section{Missouri}


MoDOT (2009). Oversize/Overweight Permits Regulations, Motor Carrier Services, Missouri Department of Transportation, Jefferson City, MO.

http://www.modot.mo.gov/mcs/documents/2009OSOWRegBook-lowres.pdf , Accessed August 16, 2009.

\section{Minnesota}

MinnDOT (2009A). Oversize/Overweight Permits, Minnesota State Permits for Commercial and Private Vehicles, Minnesota Department of Transportation, St. Paul, MN http://www.dot.state.mn.us/cvo/oversize/annualseasonalpermitchart.pdf, Accessed August 16, 2009. Camsys (2006), Minnesota Truck Size and Weight Project, Cambridge Systematics, SRF Consulting Group Inc., Harry Cohen, Tech. Rep. prepared for Minnesota DOT.

\section{Other References/Resources}

Federal Highway Cost Allocation Study (1998). Final Report on the Federal Highway Cost Allocation Study, 1997. FHWA, U.S. Department of Transportation, Washington. DC.

Federal Highway Administration (2000). Addendum to the 1997 federal highway cost allocation study final report. FHWA, http://www.fhwa.dot.gov/policy/hcas/addendum.htm. Accessed March 14, 2010.

Federal Highway Administration (2010). Highway Cost Allocation Study. http://www.fhwa.dot.gov/policy/otps/costallocation.htm .Accessed March 14, 2010.

Fu, G., and Fu, C. (2006). Bridge Rating Practices and Policies for Overweight Vehicles, NCHRP Synthesis 359, Transportation Research Board, Washington, DC.

Hajek, J. J., Tighe, S. L., and Hutchinson, B. G. (1998). Allocation of pavement deterioration due to trucks using a marginal cost method. Transportation Research Record: Journal of the Transportation Research Board, 1613, 50-56.

Humphrey, T.F. (1998). Uniformity Efforts in Oversize/Overweight Permits, NCHRP Synthesis of Practice 143. Transportation Research Board, Washington, DC.

INDOT (undated). Summary of Indiana Size and Weight Laws, under TITLE 9 Article 20, available at www.in.gov/isp/files/size_weight_laws.pdf, Accessed August 4, 2009.

ILDOT ( 2009). Oversize and Overweight Permit Movements on State Highways, Illinois Department of Transportation, Springfield, IL.

ODOT (2009). Impacts of Permitted Trucking on Ohio's Transportation System and Economy, Ohio Department of Transportation, Columbus, $\mathrm{OH}$.

OECD (1997). Dynamic Interaction of Heavy Vehicles with Roads and Bridges, Final Report, OECD DIVINE Program, Organization of Economic Cooperation and Development, Paris, France.

Noel, J.S., Keating, P.B., Mattox, M.J. and White, E.P. (1992). Overload Permit Procedures, Tech. Rep. FHWA/TX-92-1266, TTI, College Station, TX. 
Railway Association of Canada (2002). Heavy goods vehicles infrastructure costs and revenue. http://www.railcan.ca/documents/Heavy\%20Vehicules.pdf. Accessed March 14, 2010.

RJ Hansen Associates, State Laws and Regulations on Truck Size and Weight, NCHRP Report 198, Transportation Research Board, Washington, DC.

Sinha, K. C., and Labi, S. Transportation Decision Making-Principles of Project Evaluation and Programming. Jhon Wiley \& Sons, Inc., (2007).

Strauss, S.H. and Semmens, J. (2006). Estimating the Cost of Overweight Vehicle Travel on Arizona Highways, Final Report 528, Prepared for the Arizona DOT.

Texas Transportation Institute and Center for Transportation Research (1985). Texas Highway Cost Allocation, Research Report 332/362-2F, College Station and Austin, Texas, pp. 183-84.

Texas Transportation Institute (1988). Evaluation of Oversize/Overweight Permit Policy and Fee Structure, Research Report 1109-1F, Austin, Texas, p. 63.

TRB (1990). Truck Weight Limits: Issues and Options, TRB Special Report 225Transportation Research Board, Washington, DC.

Transportation Research Board (1996). Paying our way: estimating marginal social costs of freight transportation. Special Report 246, Committee for study of public policy for surface freight transportation, TRB, National Research Council, Washington, D.C.

US. DOT (1981). An Investigation of Truck Size and Weight Limits, Report to Congress, Section 161, United States Dept. of Transportation, Washington, DC.

US DOT (2000). Comprehensive Truck Size and Weight Study, Volume I (Summary Report) and Volume II (Issues and Background), The U.S. Department of Transportation, Washington, DC.

USDOT (1984). Heavy Vehicle Cost Responsibility Study- Our Highways - Why Do They Wear Out, U.S. Department of Transportation and the American Association of State Highway and Transportation Officials, Washington, D.C. pp. 5-12, p. V-1.

USDOT (1988). Heavy Vehicle Cost Responsibility Study, U.S. Department of Transportation, Washington, D.C., p. I-1.

Vitaliano, D. F., and Held, J. (1990). Marginal cost road damage and user charges. Quarterly Review of Economics and Business, 30(2), 32-49.219

Whitford, R., and Moffett, D.P. (1995). Development of Annual Permit Procedure for Overweight Trucks on Indiana Highways, Tech. Rep. FHWA/IN/JHRP-95-5, W. Lafayette, IN.

Wilbur Smith Associates, (2007). Truck Size and Weight Survey, Final Report, prepared for AASHTO Subcommittee on Highway Transport. 


\section{APPENDICES}




\section{APPENDICES}

Appendix 1: Exceptions to OSW Regulations in Indiana

Appendix 2: Methods for Acquiring Permits in the State of Indiana

Appendix 2B: Indiana Special-weight Single Trip Application Form

Appendix 3: List of Indiana Permits and Fees

Appendix 4: States of Practice - Neighboring States

Appendix 4A. Illinois DOT Maximum Weights and Dimensions

Appendix 4B. Illinois DOT Fees for Oversize Permits that fall within the Practical Maximums Appendix 4C. Illinois DOT Fees for Oversize/overweight Permits that fall within the Practical Maximums

Appendix 4D. Illinois DOT Fees for Overweight Axle Only Permits

Appendix 4E. Kentucky- OW/OD Permit Fees and Specifications

Appendix 4F. Michigan OW/OD Permits and Specifications

Appendix 4G. Ohio OW/OD Permit Fees

Appendix 4H. Minnesota OW/OD Permit Fees

Appendix 4I. Wisconsin OW/OD Permit Fees

Appendix 4J. Missouri OW/OD Permit Fees

Appendix 4K. Iowa OW/OD Permit Fees

Appendix 5: The Special Case of Oregon

Appendix 6: Unit Pavement Costs (Usdot, 2000) 


\section{APPENDIX 1: EXCEPTIONS TO OSW REGULATIONS IN INDIANA}

There are certain exemptions from oversize/overweight permits. When traveling on any road other than an interstate highway, certain vehicles are exempt from the permitting requirements. They include:

1. A vehicle engaged in the construction of highways, when the movement of the vehicle is confined to highways, roads, or sections that are under construction and not yet open to the public. The only exception to this would be if the authority having jurisdiction over the construction of a public highway gives notice that a permit is needed.

2. Machinery or equipment used in highway construction or maintenance by the Indiana Department of Transportation, or by Indiana counties or municipalities.

3. Implements of agriculture when used during farming operations or when so constructed that the implements can be moved without material damage to highways.

4. The width or height of a farm vehicle loaded with a farm product. This includes a truck hauling unprocessed tobacco leaf.

5. Fire-fighting apparatus owned or operated by a political subdivision or volunteer fire company.

6. The movement of a disabled vehicle or combination of vehicles for a distance that does not exceed fifty (50) highway miles by a registered recovery vehicle or by a vehicle described in MCSD (2008) is exempt from the dimension and weight limits under this article.

Source: Oversize-Overweight Vehicle Permitting Handbook, Permit Unit, Motor Carrier Services Division, Indiana Department of Revenue, Indianapolis, IN. http://www.in.gov/dor/files/osowhandbook.pdf 


\section{APPENDIX 2A: LIST OF INDIANA PERMITS AND FEES}

\section{List of Permits and Fees}

Any questions that you have regarding information in this handbook should be directed to:

$$
\begin{aligned}
& \text { Indiana Department of Revenue } \\
& \text { Permit Unit } \\
& \text { 5252 Decatur Boulevard, Suite R } \\
& \text { Indianapolis, IN } 46241 \\
& \text { (317) 615-7320 }
\end{aligned}
$$

\begin{tabular}{|c|c|c|c|c|c|}
\hline Category & Type & Forms & Single Trip Fee & $\begin{array}{l}90 \text { Day } \\
\text { Fee }\end{array}$ & $\begin{array}{c}\text { Annual } \\
\text { Fee }\end{array}$ \\
\hline $\begin{array}{l}\text { Oversize } \\
\text { Permit }\end{array}$ & $\begin{array}{l}\text { Single } \\
\text { Trip } \\
90 \text { Day } \\
\text { Annual }\end{array}$ & $\begin{array}{l}\text { M-233, Permit } \\
\text { M-233, Permit } \\
\text { M-233, Permit }\end{array}$ & $\begin{array}{l}\text { \$20: up to } 95^{\prime} \text { in length, } 12^{\prime} 4^{\prime \prime} \text { wide } \\
\text { \& legal height } \\
\$ 30 \text { : between } 96^{\prime} \text { and } 110^{\prime} \text { in length, } \\
12^{\prime} 5^{\prime \prime} \text { and } 16^{\prime} \text { wide or } 13^{\prime} 7^{\prime \prime} \text { and } 15^{\prime} \\
\text { tall } \\
\$ 40 \text { : over } 110^{\prime} \text { in length, } 16^{\prime} \text { wide, } \\
15^{\prime} \text { tall and } 80,000 \text { pounds }\end{array}$ & $\$ 100$ & $\$ 405$ \\
\hline $\begin{array}{l}\text { Overweight } \\
\text { Permit }\end{array}$ & $\begin{array}{l}\text { Single } \\
\text { Trip (15 } \\
\text { Days) }\end{array}$ & M-233, Permit & $\begin{array}{l}\$ 20+\$ .35 \text { per mile for vehicles up } \\
\text { to } 108,000 \text { lbs. } \\
\text { * } \$ 20+\$ .60 \text { per mile for vehicles } \\
\text { over } 108,000 \text { to } 150,000 \text { lbs. } \\
\text { * } \$ 20+\$ 1.00 \text { per mile for vehicles } \\
\text { over } 150,000 \text { lbs. }\end{array}$ & & \\
\hline $\begin{array}{l}\text { Oversize \& } \\
\text { Overweight } \\
\text { Permit }\end{array}$ & $\begin{array}{l}\text { Single } \\
\text { Trip } \\
\text { (15 Days) }\end{array}$ & M-233, Permit & $\begin{array}{l}\text { Greater of the oversize or } \\
\text { overweight fee calculated above }\end{array}$ & & \\
\hline $\begin{array}{l}\text { Special Weight } \\
\text { Permit }\end{array}$ & $\begin{array}{c}\text { Multiple } \\
\text { Trip (1 } \\
\text { Day) } \\
\text { Quarterly } \\
\text { billing }\end{array}$ & $\begin{array}{l}\text { M-233ST, Permit } \\
\text { M-211, Registration } \\
\text { M-219, Bond Form }\end{array}$ & $\$ 42.50$ & & \\
\hline $\begin{array}{l}\text { 12'4" Mobile } \\
\text { Home Rig } \\
\text { Permit }\end{array}$ & $\begin{array}{c}\text { Single } \\
\text { Trip (15 } \\
\text { Days) } \\
\text { Annual } \\
\text { Quarterly } \\
\text { Dealer's }\end{array}$ & $\begin{array}{l}\text { M-233, Permit } \\
\text { M-233DR, Permit }\end{array}$ & $\$ 10.00$ & $\$ 250.00$ & $\begin{array}{l}\$ 1000.00 \\
\$ 40.00 \text { for } \\
\text { dealers. }\end{array}$ \\
\hline $\begin{array}{l}\text { 14'4" Mobile } \\
\text { Home Rig } \\
\text { Permit }\end{array}$ & $\begin{array}{l}\text { Single } \\
\text { Trip (5) } \\
\text { Days } \\
\text { Quarterly } \\
\text { Annual }\end{array}$ & M-233, Permit & $\$ 18.00$ & $\$ 500.00$ & $\$ 2000.00$ \\
\hline $\begin{array}{l}\text { Toll Road Gate } \\
\text { Permit }\end{array}$ & Annual & M-233T, Permit & & & $\begin{array}{l}\$ 20 \text { per gate, } \\
\text { per truck. }\end{array}$ \\
\hline
\end{tabular}

All permit applicants must file Form M-203, Transporting Company Permit Application!

* Vehicles over $120,000 \mathrm{lbs}$ charged $\$ 10$ executive fee.

$* *$ Vehicles over 200,000 lbs charged $\$ 10$ executive fee $+\$ 25$ design and review fee + bridges fees.

Source: Oversize-Overweight Vehicle Permitting Handbook, Permit Unit, Motor Carrier Services Division, Indiana Department of Revenue, Indianapolis, IN. 


\section{APPENDIX 2B: INDIANA SPECIAL-WEIGHT SINGLE-TRIP APPLICATION FORM}

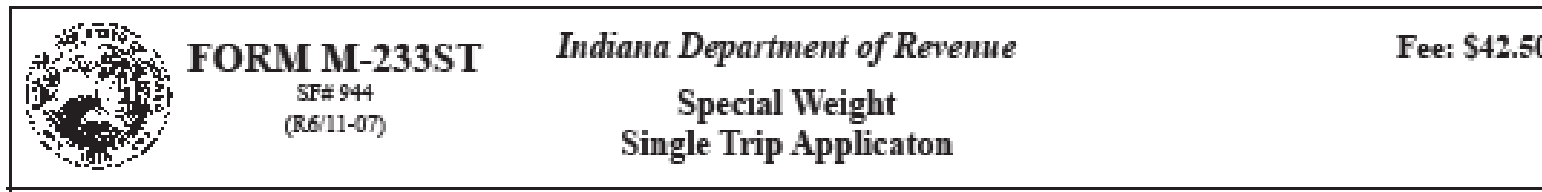

(1) Name of Transporting Company:

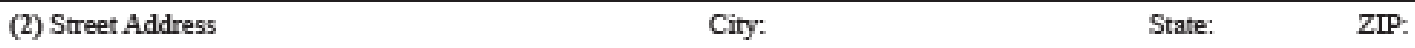

(3) Start Date $\quad$ (4) Start Time

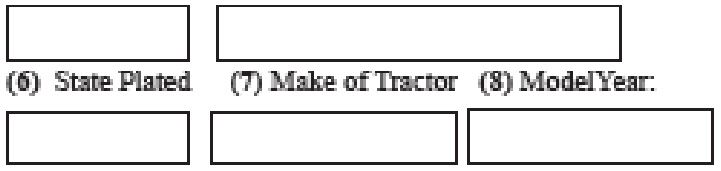

(10) License Plate Number

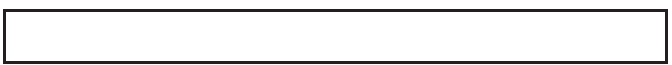

Overall Length: $\quad$ Legal
(5) Fax Number

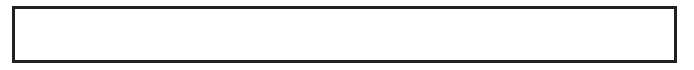

(9) Full Vehicle Identification Number

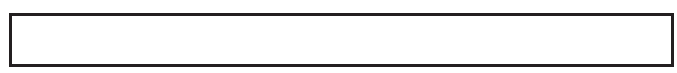

(11) Vehicle Type

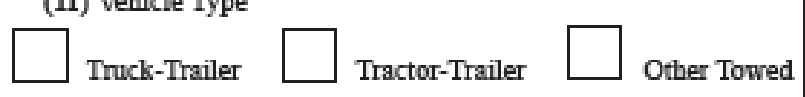

Overall Height: Legal

Allowable Weights: Single axle weight must not exceed 18,000 pounds per axle; no axle in any axle combination may exceed 13,000 pounds per axle, with the exception of one tandem group that may weigh 16,000 pounds per axle or a total of 32,000 pounds. The maximum gross weight must not exceed 134,000 pounds for routes $1-21$ below and $90,000 \mathrm{lbs}$ for route 22 below; axle spacings may not be less than 3'6" between each axle in an axle combination; axle spacings may not be less than 8 feet between each axle or axle combination; weight per inch width of tire measured between flanges of rim shall not exceed 800 pounds.

The provisions on the reverse side of this form are incorporated by reference into this permit and are as fully binding upon the permittee as if they had appeared on the face of this permit. This permit is void or invalid if the provisions are omitted from the revise side of this form or are not attached.

The Permit is Valid Over State Roads: (1) US 41, from 129th Street in Hammond to SR 312, (2) Highway 312, from Highway 41 to State Road 912, (3) Highway 912, from Michigan Avenue in East Chicago to the U.S. 20 interchange, (4) Highway 20, from Clark Road in Gary to Highway 39, (5) Highway 12, from one-fourth (1/4) mile west of the Midwest Steel entrance to Highway 249, (6) Highway 249 , from Highway 12 to Highway 20 , (7) Highway 12 , from one and one-half $(11 / 2)$ miles east of the Bethlehem Steel entrance to Highway 149 , (8) Highway 149 , from Highway 12 to a point thirty-six hundredths (.36) of a mile south of Highway 20 , (9) Highway 39, from Highway 20 to the Michigan state line, (10) Highway 20, from Highway 39 to Highway 2, (11) Highway 2, from Highway 20 to Highway 31, (12) Highway 31, from the Michigan state line to Highway 23, (13) Highway 23, from Highway 31 to Olive Street in South Bend, (14) Highway 35, from South Motts Parkway thirty-four hundredths (.34) of a mile southeast to the point where Highway 35 intersects with the overpass for Highway 20/Highway 212, (15) State Road 249 from U.S. 12 to the point where State Road 249 intersects with Nelson Drive at the Port of Indiana, (16) State Road 912 from the 15 th Avenue and 169 th Street interchange one and six hundredths (1.06) miles north to the U.S. 20 interchange, (17) U.S. 20 from the State Road 912 interchange three and seventeen hundredths (3.17) miles east to U.S.12, (18) U.S. 6 from the Ohio State line to State Road 9, (19) U.S. 30 from Allen County/Whitley County Line Road (also know as County Road 800 East) to State Road 9, (20) State Road 9 from U.S. 30 to U.S. 6 , (21) State Road 39 from Interstate 80 to U.S. 20, (22) State Road 3 north from U.S. 6 to U.S. 20, U.S. 20 west from State Road 3 to State Road 9, State Road 9 north from U.S. 20 to the Michigan state line.

No other routes, including detours, are authorized by this permit under any condition.

This permit is valid only for transporting commodities under the company name shown above, and if signed by both an authorized company owner or officer, and driver. The driver's signature attests to the fact that the description of the vehicle is accurate and that the provisions on the reverse side of this permit have been read and understood by the driver. Under the penalty of perjury, I have examined this permit, and to the best of my knowledge and belief, it is true, complete and correct. I also understand that all provisions of the Transporting Agreement apply in full force.

\begin{tabular}{ll|}
\hline Driver's Signature & Date \\
\hline Driver's Signature & Date
\end{tabular}




\section{APPENDIX 3: METHODS FOR ACQUIRING PERMITS IN THE STATE OF INDIANA}

(a) Internet

This is the newest mechanism for permit acquisition. It was designed by INDOR to further facilitate the permitting process and to make it convenient for the trucking organizations. The applicant applies for the permit online. INDOR uses the internet-based Oversize/Overweight Vehicle Permitting System. To register special weights, the applicant visits the OSW webpage, clicks on "Special Weight Vehicle Registration", selects the year they are registering for and add their vehicle information including the full VIN number. After adding all their vehicles, the applicant pays the $\$ 25$ registration fee before ordering any Special Weight permits. After entering and registering all their vehicles, the applicant will just need to renew their Special Weight Registration annually. The applicant may also add, edit or delete trucks at any time at no additional cost. To order a special weight permit the vehicle must be registered.

At any time, the applicant may check the status of their permit applications by log into their account and finding a section labeled "My Recent Applications". On clicking that link, the resulting screen will show all the Applicant's recent permit applications and the status of each application, as well as any review needed by the Indiana State Police (for escorting needs) or by an INDOT engineer (for overload analysis).

There are two ways for applicants to check/know that their permits are ready: (i) go to their computer and periodically sign in and check their account. Looking under the "View Approved Permits" screen, the applicant will find all permits that are approved and ready to be paid, issued and printed, (ii) receiving an email message each time one of the applicant's permits is approved. Once the applicant receives the email, they can log into the system, pay for, and print their permit.

(b) Permitting Service

Applicants for trucks permits in Indiana may also go through a number of companies nationwide that offer active permit services. A list of these companies is provided by the Indiana Department of Revenue.

(c) Mail

Applicants may order an Indiana oversize/overweight vehicle permit by first entering into a written agreement with Indiana. They complete form M-203 (Transporting Company Permit Application) and fax the completed form to (317) 821-2336, or mail to Motor Carrier Services, 5252 Decatur Boulevard, Suite R, Indianapolis, IN 46241.

(d) Walk In

Applicants may personally visit the offices of the Permit Unit of the Indiana Motor Carrier Services at 5252 Decatur Boulevard, Suite R, Indianapolis, to apply for a permit.

(e) Fax

Source: Indiana Oversize/Overweight Permitting System - Final Report and User Manual, Permit Unit, Motor Carrier Services Division, Indiana Department of Revenue, Indianapolis, IN. http://www.in.gov/dor/files/osw-manual.pdf 


\section{APPENDIX 4 - STATES OF PRACTICE - NEIGHBORING STATES}

\section{Appendix 4A. Illinois DOT Maximum Weights and Dimensions}

(7) Illinois Department

TABLE I: Maximum legal dimensions of motor vehicles

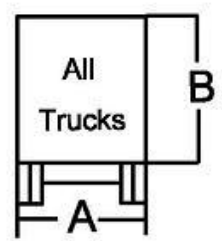

Width \& Height

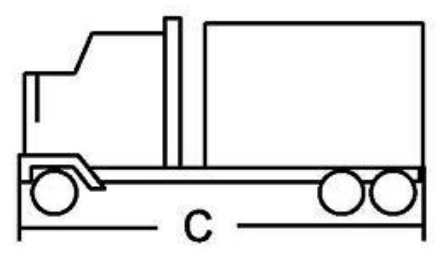

Length, Single Vehicle
Maximum Legal

Dimensions \& Weights

On State, Federal \& Local Routes

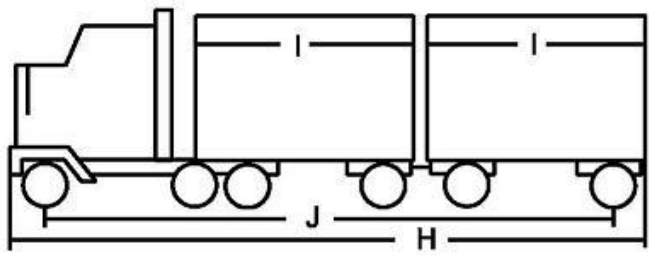

Length, Tractor-Semitrailer Trailer(Double Bottom)

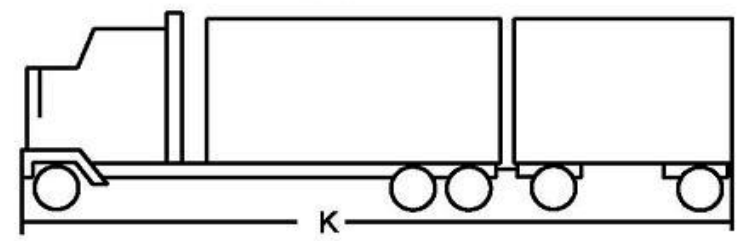

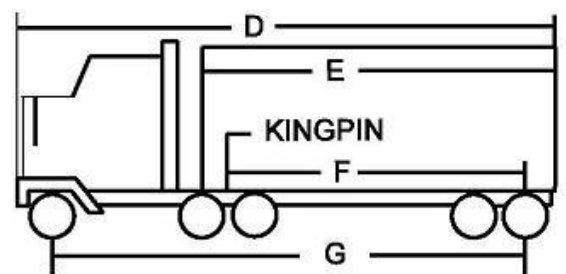

Length, Tractor-Semitrailer

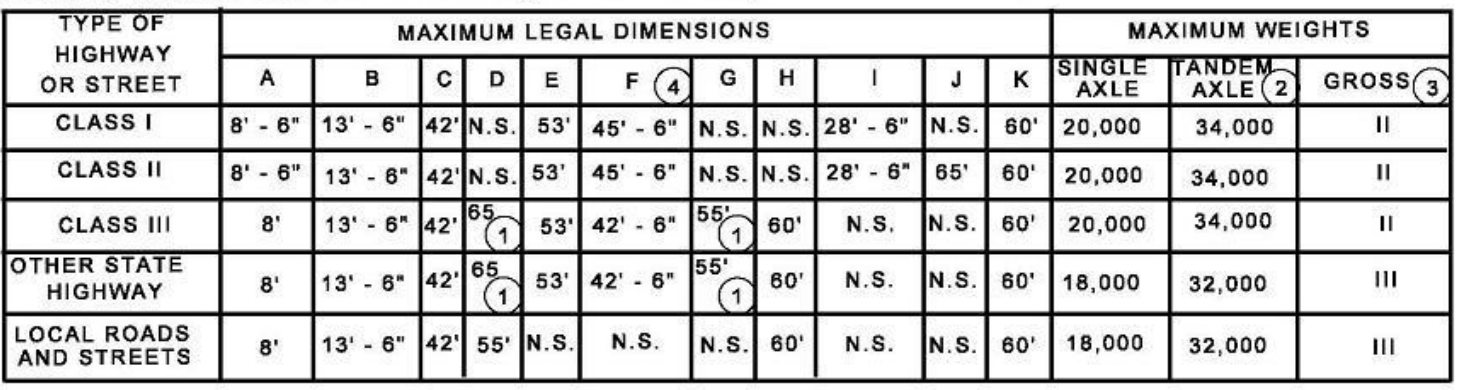

N.S. indicates legal dimension not specified.

Notes:

165 feet overall length (bumper to bumper) and/or 55 feet from center of front axle to center of rear axle.

2 Tandem is defined as any 2 or more single axles whose centers are more than 40 inches and not more than 96 inches apart, measured to the nearest inch between extreme axles.

3 See tables II and III.

4 Applies on semitrailers longer than 48 feet.

Exceptions to WIDTH requirements above:

- Does not include certain safety devices approved by Department.

- Household goods carriers shall have access to points of loading and unloading and may have a maximum width of 8 feet 6 inches.

- A maximum width of 8 feet 6 inches is allowed on any street or highway to any point of loading or unloading for vehicle combinations that include a trailer or semitrailer not exceeding 28 feet 6 inches in length, which was originally part of a truck tractor-semitrailer-trailer combination (double-bottom).

- Width restrictions do not apply to vehicles transporting implements of husbandry operating in the daytime. Loads of hay, straw or other similar farm products are limited to a maximum of 12 feet.

Exceptions to LENGTH requirements above:

- Length limits do not apply to vehicles operating in the daytime except on Saturdays, Sundays or legal holidays when transporting poles, pipes, machinery or other objects of a structural nature which cannot be readily dismembered, provided the length of the object being transported does not exceed 80 feet and the overall length of the load does not exceed 100 feet.

- Stinger-steered vehicles specifically designed to transport motor vehicles or boats may have an overall length of 75 feet plus overhang of 3 feet in front and 4 feet in the rear on Class I and II highways.

- Conventional auto transporters are vehicles specifically designed to transport motor vehicles or boats may have an overall length of 65 feet plus overhang on these highways. The maximum overall length on all other streets and highways is 60 feet.

General exceptions to above Table:

- $\quad$ All large vehicles operating on Class I highways shall have access for a distance of one mile on any street or highway to points of loading and unloading, and facilities for food, fuel, rest and repair.

- Large vehicles operating on designated state highways shall have access for a distance of 5 highway miles on any other state highway and on designated local streets and highways, to points of loading and unloading, and facilities for food, fuel, rest and repair. (This applies only on local streets and highways specifically designated and posted by local officials.)

- Permits may be issued for overdimensional objects and vehicles if they have been reasonably disassembled. Multiple objects loaded side-by-side, end-to-end, or on top of each other may not cause the overdimension.

- Streets or highways are designated by the Department of Transportation or local officials having jurisdiction. 


\begin{tabular}{|c|c|c|c|c|c|c|c|c|c|c|c|c|c|c|c|}
\hline \multirow{2}{*}{$\begin{array}{c}\text { Special Haul } \\
\text { Vehicles } \\
\end{array}$} & \multirow{2}{*}{$\begin{array}{l}\text { Type of } \\
\text { Highway } \\
\text { or Street } \\
\end{array}$} & \multicolumn{11}{|c|}{ Maximum Legal Dimensions } & \multicolumn{3}{|c|}{ Maximum Weights } \\
\hline & & A & B & C & D & $E$ & $\mathrm{~F}$ & $\mathrm{G}$ & $\mathrm{H}$ & 1 & $\mathrm{~J}$ & $\mathrm{~K}$ & \begin{tabular}{l|l|} 
Single \\
Axle
\end{tabular} & \begin{tabular}{c|}
$\begin{array}{c}\text { Tandem } \\
\text { Axle }\end{array}$ \\
\end{tabular} & Gross \\
\hline $\begin{array}{l}\text { for additional } \\
\text { information on }\end{array}$ & $\begin{array}{c}\text { Class I,II,III } \\
\text { Other State } \\
\text { Highwavs and }\end{array}$ & $\begin{array}{r}8^{\prime} 66^{\prime \prime} \\
\end{array}$ & $13^{\prime} 6^{\prime \prime}$ & $42^{\prime}$ & N.S. & $\mathrm{N}$ & N.S. $\mathrm{N}$ & N.S & N.S. & N. & N.S. & $\left|60^{\prime}\right|$ & 20,000 & See 4 & $\begin{array}{r}\mathrm{See} \\
\quad 5 \\
\end{array}$ \\
\hline & $\begin{array}{l}\text { Local Roads } \\
\text { And Streets } \\
\end{array}$ & & & & & & & & & & & & & & \\
\hline
\end{tabular}

Notes:

$18^{\prime}$ on Class III, Other State Highways, Local Roads and Streets.

$255^{\prime}$ on Local Roads and Streets, 65' from designated State Highway (5 mile access law).

318,000 pounds on Other State Highways, Local Roads and Streets.

4 Greater than 72" and not more than 96" may carry 18,000 pounds on each axle.

5 Gross weight is determined by measuring to the nearest foot between extreme axles. ( $\leq 42$ ' see Table III, $>42$ ' see Table II)

Maps of the designated state truck route system are available by calling 217/782-6271 and at www.gettingaroundillinois.com

TABLE II: Maximum gross weight for vehicles on Class I, II, and III highways of the designated state highway truck route system. Based on federal bridge formula. All special conditions and exceptions are not included on this form. Maximum load in pounds on any

\begin{tabular}{|c|c|c|c|c|c|}
\hline & $\begin{array}{c}\text { Max } \\
2\end{array}$ & $\begin{array}{l}\text { load in } \\
\text { re conse }\end{array}$ & $\begin{array}{l}\text { ls on ar } \\
\text { e axles }\end{array}$ & & \\
\hline Distance & 2 axdes & 3 axles & 4 axces & 5 axles & 6 axte \\
\hline 8 (1) & 34,000 & 42,000 & & (2) & (2 \\
\hline 9 & 39,000 & 42,500 & & & \\
\hline 10 & 40,000 & 43,500 & & & \\
\hline 11 & & 44,000 & & & \\
\hline 12 & & 45,000 & 50,000 & & \\
\hline 13 & & 45,000 & 50,500 & & \\
\hline 14 & & 46,500 & 51,000 & & \\
\hline 15 & & 47,000 & 51,500 & & \\
\hline 16 & & 48,000 & 52,500 & 58,000 & \\
\hline 17 & & 48,500 & 53,500 & 58,500 & \\
\hline 18 & & 49,500 & 54,000 & 59,000 & \\
\hline 19 & & 50,000 & 54,500 & 60,000 & \\
\hline 20 & & 51,000 & 55,500 & 60,500 & 66,000 \\
\hline 21 & & 51,500 & 56,000 & 61,000 & 68,500 \\
\hline 22 & & 52,500 & 56,500 & 61,500 & 67,000 \\
\hline 23 & & 53,000 & 57,500 & 62,500 & 68,000 \\
\hline 24 & & 54,000 & 58,000 & 63,000 & 68,500 \\
\hline & & $\begin{array}{l}54,500 \\
55,500\end{array}$ & 58,500 & 63,500 & $\begin{array}{l}69,000 \\
69500\end{array}$ \\
\hline 26 & & 55,500 & 59,500 & $\begin{array}{l}64,000 \\
65000\end{array}$ & $\begin{array}{l}69,500 \\
7000\end{array}$ \\
\hline 27 & & 56,000 & 60,000 & $\begin{array}{l}65,000 \\
85,500\end{array}$ & 70,000 \\
\hline 28 & & 57,000 & 60,500 & 65,500 & 71,000 \\
\hline 28 & & 57,500 & 61,500 & 66,000 & 71,500 \\
\hline 30 & & 58,500 & 62,000 & 66,500 & 72,000 \\
\hline 31 & & 59,000 & 62,500 & 67.500 & 72,500 \\
\hline 32 & & 60,000 & 63.500 & 68,000 & 73,000 \\
\hline 33 & & & 64,000 & 68,500 & 74,000 \\
\hline 34 & & & 64,500 & 69,000 & 74,500 \\
\hline 35 & & & 65,500 & 70,000 & 75,000 \\
\hline 36 & & & 66,000 & 70,500 & 75.500 \\
\hline 37 & & Exception & 66,500 & 71,000 & 76,000 \\
\hline 38 & & & 67,500 & 72,000 & 77,000 \\
\hline 39 & & & $68,000^{-}$ & 72,500 & 77,500 \\
\hline 40 & & & 68,500 & 73,000 & 78,000 \\
\hline 41 & & & 89,500 & 73,500 & 78,500 \\
\hline 42 & & & 70,000 & 74,000 & 79,000 \\
\hline 43 & & & 70,500 & 75,000 & 80,000 \\
\hline 44 & & & 71,500 & 75,500 & \\
\hline 45 & & & 72,000 & 76,000 & \\
\hline 46 & & & 72,500 & 76,500 & \\
\hline 47 & & & 73,500 & 77,500 & \\
\hline 48 & & & 74,000 & 78,000 & \\
\hline 49 & & & & 78,500 & \\
\hline 50 & & & & 79,000 & \\
\hline 51 & & & & 80,000 & \\
\hline
\end{tabular}

Maximum loading for typical vehicles Vehicle or Combination Maximum Weight - Pounds
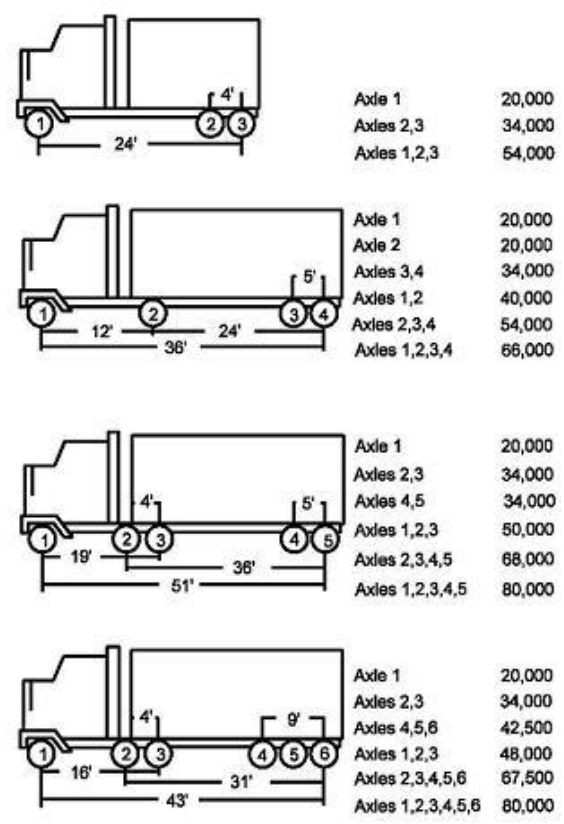

Notes:

1 Measured to the nearest foot between the extremes of any group of two or more consecutive axles.

2 Gross weights for 5 and 6 axles applicable only to a combination of vehicles.

3 Two consecutive sets of tandems may carry 34,000 pounds each providing the overall distance between the first and last axles of such consecutive sets of tandems is 36 feet or more.

4 If the distance between the centers of the first and third axles in a group of consecutive axles does not exceed 96 inches, the group is a tandem.

5 Maximum single axle 20,000 pounds; maximum tandem 34,000 pounds.

6 Combinations of vehicles designated as special haul vehicles which include a semitrailer manufactured prior to the model year 2004 and first registered in Illinois prior to January 1, 2005 having five axles with a distance of 42 feet or less between extreme may have a gross weight of 72,000 pounds provided the weight shall not exceed 18,000 pounds on a single axle or 32,000 pounds on a tandem. For such combinations manufactured subsequent to September 9, 1986, the minimum distance between the first and last axles of the two sets of tandems must be 18 feet 6 inches or more.

7 Permits may be issued for an overweight load providing it consists of one object that cannot be reasonably dismantled or disassembled. 
TABLE IV: Special Axle and Gross Weight Allowances for Special Haul Vehicles
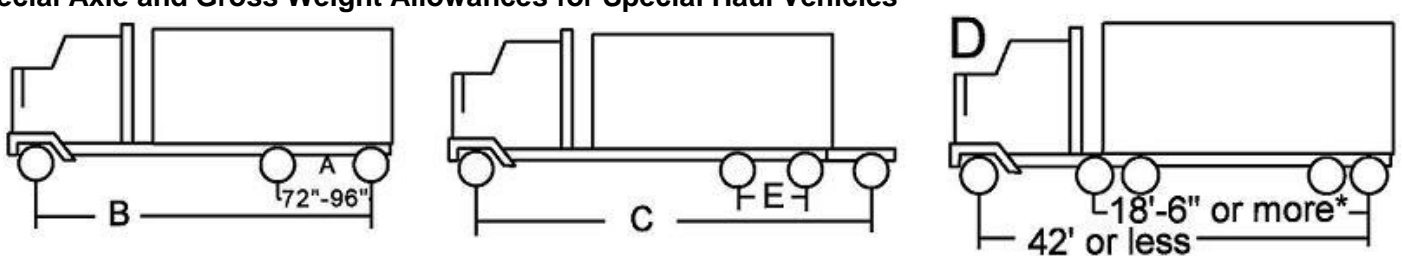

Designated Truck Route System (Class I,II \& III State Highways)

A. $18,000 \mathrm{lbs}$. on each axle - total of $36,000 \mathrm{lbs}$.

B. See Table II

C. See Table II

D. Gross weight of $72,000 \mathrm{lbs} .$, provided the weight shall not exceed 18,000 Ibs. on a single axle or $32,000 \mathrm{lbs}$. on a tandem.

Other State Highways and Local Roads \& Streets

A. $18,000 \mathrm{lbs}$. on each axle - total of $36,000 \mathrm{lbs}$.

B. See Table III

C. See Table III

D. Gross weight of $72,000 \mathrm{lbs}$, provided the weight shall not exceed 18,000 Ibs. on a single axle or $32,000 \mathrm{lbs}$. on a tandem.

* This requirement does not apply to semitrailers manufactured before September 9, 1986.

Note: -Special Hauling Vehicles must meet width, height and length requirements as specified in Table I.

-4-axle concrete mixers are allowed the following maximum weights: $20,000 \mathrm{lbs}$. on any single axle; $36,000 \mathrm{lbs}$. on any series of 2 axles greater than 72 inches but not more than 96 inches; and 34,000 lbs. on any series of 2 axles greater than 40 inches but not more than 72 inches.

Source: Informational Forms, IDOT Oversize/Overweight Permit Office, Springfield IL http://www.dot.il.gov/road/infoforms.html 


\section{Appendix 4B. Illinois DOT Fees for overdimension-only permits that fall within the Practical Maximums}

TABLE 1. OVERDIMENSION FEE CATEGORIES

\begin{tabular}{|c|c|c|c|c|c|c|}
\hline \multirow[b]{2}{*}{ Category } & \multirow[b]{2}{*}{ Dimensions } & \multicolumn{4}{|c|}{ Distances - Single Trip Fees } & \multirow{2}{*}{$\begin{array}{c}\text { Limited } \\
\text { Continuous } \\
\text { Operation } \\
\text { Permit } \\
\end{array}$} \\
\hline & & 0 to $90 \mathrm{mi}$ & 91 to $180 \mathrm{mi}$ & 181 to $270 \mathrm{mi}$ & Over $270 \mathrm{mi}$ & \\
\hline a & $\begin{array}{l}10^{\prime} \text { wide or less } \\
14^{\prime}-6^{\star} \text { high or less } \\
70^{\prime} \text { long or less }\end{array}$ & $\$ 12$ & $\$ 15$ & $\$ 18$ & $\$ 21$ & $\$ 100$ \\
\hline b & $\begin{array}{l}12 \text { ' wide or less } \\
14^{\prime} 6^{\star} \text { high or less } \\
85^{\prime} \text { long or less }\end{array}$ & $\$ 15$ & $\$ 20$ & $\$ 25$ & $\$ 30$ & $\$ 150$ \\
\hline c & $\begin{array}{l}14^{\prime} \text { wide or less } \\
15^{\prime} \text { high or less } \\
100^{\prime} \text { long or less } \\
\text { Mobile home } \\
\text { combinations } \\
85^{\prime} \text { long or less } \\
\end{array}$ & $\$ 25$ & $\$ 30$ & $\$ 35$ & $\$ 40$ & Not available \\
\hline d & $\begin{array}{l}\text { 18' wide or less }{ }^{\star \star} \\
16 \text { ' high or less } \\
120^{\prime} \text { long or less }\end{array}$ & $\$ 30$ & $\$ 40$ & $\$ 50$ & $\$ 60$ & Not avallable \\
\hline e & $\begin{array}{l}\text { More than } 18 \text { ' wide }{ }^{\star \star} \\
\text { More than } 16^{\prime} \text { high } \\
\text { More than } 120^{\prime} \text { long }\end{array}$ & $\$ 50$ & $\$ 75$ & $\$ 100$ & $\$ 125$ & Not available \\
\hline
\end{tabular}

"Mobile home combinations greater than 85 ' long, use Category d.

*Permits available only for limited distances as indicated in Section $\underline{\mathbf{5 4} 4.505}$ (d)

Source: Informational Forms, IDOT Oversize/Overweight Permit Office, Springfield IL http://www.dot.il.gov/road/infoforms.html

Continued... 


\section{Appendix 4C. Illinois DOT Fees for overdimension/overweight permits that fall within the Practical Maximums}

TABLE 2 - OVERWEIGHT FEE CATAGORIES*

\begin{tabular}{|c|c|c|c|c|c|c|c|c|c|c|c|c|c|}
\hline Category & $f$ & $\mathbf{g}$ & $\mathrm{h}$ & $\mathbf{i}$ & j & k & I & $m$ & $n$ & 0 & $p$ & $q$ & $r$ \\
\hline $\begin{array}{l}\text { Total Axles } \\
\text { Gross Weight (max) } \\
\text { Front tandem or axle } \\
\text { (max)/axles } \\
\text { Rear tandem or axle } \\
\text { (max)/axles }\end{array}$ & $\begin{array}{l}6 \text { or } \\
\text { more } \\
88,000 \\
34,000 / 2 \\
48,000 / 3\end{array}$ & $\begin{array}{l}6 \text { or } \\
\text { more } \\
100,000 \\
44,000 / 2 \\
54,000 / 3\end{array}$ & $\begin{array}{l}6 \text { or } \\
\text { more } \\
110,000 \\
44,000 / 2 \\
54,000 / 3\end{array}$ & $\begin{array}{l}6 \text { or } \\
\text { more } \\
120,000 \\
48,000 / 2 \\
60,000 / 3\end{array}$ & \begin{tabular}{l}
\multicolumn{1}{c}{5} \\
88,000 \\
$44,000 / 2$ \\
$44,000 / 2$
\end{tabular} & $\begin{array}{c}5 \\
100,000 \\
44,000 / 2 \\
44,000 / 2\end{array}$ & $\begin{array}{c}5 \\
100,000 \\
48,000 / 2 \\
48,000 / 2\end{array}$ & $\begin{array}{l}4 \text { or } \\
\text { more } \\
72,000 \\
34,000 / 2 \\
40,000 / 2\end{array}$ & $\begin{array}{l}4 \text { or } \\
\text { more } \\
78,000 \\
44,000 / 2 \\
44,000 / 2\end{array}$ & $\begin{array}{l}3 \text { or } \\
\text { more } \\
60,000 \\
21,000 / 1 \\
40,000 / 2\end{array}$ & $\begin{array}{l}3 \text { or } \\
\text { more } \\
68,000 \\
21,000 / 1 \\
48,000 / 2\end{array}$ & $\begin{array}{l}2 \\
48,000 \\
25,000 / 1\end{array}$ & $\begin{array}{l}2 \\
54,000 \\
28,000 / 1\end{array}$ \\
\hline DISTANCE & & & & & & & & & & & & & \\
\hline O TO 45 MILES & $\$ 10$ & $\$ 15$ & $\$ 20$ & $\$ 30$ & $\$ 20$ & $\$ 30$ & $\$ 30$ & $\$ 15$ & $\$ 20$ & $\$ 12.50$ & $\$ 20$ & $\$ 15$ & $\$ 20$ \\
\hline 46 to 90 mile & $\$ 12.50$ & 525 & $\$ 32.50$ & $\$ 55$ & $\$ 32.50$ & $\$ 55$ & $\$ 55$ & $\$ 25$ & $\$ 32.50$ & $\$ 21.50$ & $\$ 32.50$ & $\$ 25$ & $\$ 32.50$ \\
\hline 94 to 135 mile & $\$ 15$ & $\$ 35$ & $\$ 45$ & $\$ 80$ & $\$ 45$ & $\$ 80$ & $\$ 80$ & $\$ 35$ & $\$ 45$ & $\$ 30.50$ & $\$ 45$ & $\$ 35$ & $\$ 45$ \\
\hline 136 TO 180 mile & $\$ 17.50$ & $\$ 45$ & $\$ 57.50$ & $\$ 105$ & $\$ 57.50$ & $\$ 105$ & $\$ 105$ & $\$ 45$ & $\$ 57.50$ & $\$ 39.50$ & $\$ 57.50$ & $\$ 45$ & $\$ 57.50$ \\
\hline 181 TO 225 mile & $\$ 20$ & $\$ \$ 5$ & $\$ 70$ & $\$ 130$ & $\$ 70$ & $\$ 130$ & $\$ 130$ & $\$ 55$ & $\$ 70$ & $\$ 48.50$ & $\$ 70$ & $\$ 55$ & $\$ 70$ \\
\hline 226 TO 270 mile & $\$ 22.50$ & $\$ 65$ & $\$ 82.50$ & $\$ 155$ & $\$ 82.50$ & $\$ 155$ & $\$ 155$ & $\$ 65$ & $\$ 82.50$ & $\$ 57.50$ & $\$ 82.50$ & $\$ 65$ & $\$ 82,50$ \\
\hline 271 to 315 mile & $\$ 25$ & $\$ 75$ & $\$ 95$ & $\$ 180$ & $\$ 95$ & $\$ 180$ & $\$ 180$ & $\$ 75$ & $\$ 95$ & $\$ 66.50$ & $\$ 95$ & $\$ 75$ & $\$ 95$ \\
\hline 316 to 360 mile & $\$ 27.50$ & $\$ 85$ & $\$ 107.50$ & $\$ 205$ & $\$ 107.50$ & $\$ 205$ & $\$ 205$ & $\$ 85$ & $\$ 107.50$ & $\$ 75.50$ & $\$ 107.50$ & $\$ 85$ & $\$ 107.50$ \\
\hline 361 to 405 mile & $\$ 30$ & $\$ 95$ & $\$ 120$ & $\$ 230$ & $\$ 120$ & $\$ 230$ & $\$ 230$ & $\$ 95$ & $\$ 120$ & $\$ 84.50$ & $\$ 120$ & $\$ 95$ & $\$ 120$ \\
\hline 406 to 450 mile & $\$ 32.50$ & $\$ 105$ & $\$ 132.50$ & $\$ 255$ & $\$ 132.50$ & $\$ 255$ & $\$ 255$ & $\$ 105$ & $\$ 132.50$ & $\$ 93.50$ & $\$ 132.50$ & $\$ 105$ & $\$ 132.50$ \\
\hline 451 to 495 mile & $\$ 35$ & $\$ 115$ & $\$ 145$ & $\$ 280$ & $\$ 145$ & $\$ 280$ & $\$ 280$ & $\$ 115$ & $\$ 145$ & $\$ 102.50$ & $\$ 145$ & $\$ 115$ & $\$ 145$ \\
\hline
\end{tabular}

"Fee includes all overneight, all overlength, and 12 feel or less in width.

For loads greater than 12 feet wide. add $\$ 15$ to the fee indicated in this Table.

p:twinwordtable2.doclcis2tbhatnad:1013196

Source: Informational Forms, IDOT Oversize/Overweight Permit Office, Springfield IL

http://www.dot.il.gov/road/infoforms.html

Continued... 


\section{Appendix 4D. Illinois DOT Fees for overweight axle only permits}

TABLE 3. FEES FOR OVERWEIGHT AXLES (GROSS LEGAL)*

\begin{tabular}{|c|c|c|c|}
\hline \multirow{2}{*}{$\begin{array}{l}\text { Axle Weight in } \\
\text { Excess of Legal }\end{array}$} & \multicolumn{2}{|c|}{ Fees for Each 45 Mile Increment } \\
\cline { 2 - 5 } & Single Axle & 2-Axle Tandem & 3-Axle Tandem \\
\hline \hline $1-6,000$ lbs. & $\$ 5$ & $\$ 5$ & $\$ 5$ \\
\hline $6,001-11,000$ lbs. & $\$ 8$ & $\$ 7$ & $\$ 7$ \\
\hline $11,001-17,000$ lbs. & N.A. & $\$ 8$ & $\$ 1$ \\
\hline $17,001-22,000$ lbs. & N.A. & N.A. & $\$ 9$ \\
\hline $22,001-29,000$ lbs. & N.A. & N.A. & $\$ 11$ \\
\hline
\end{tabular}

*Fee does not include any over dimension. If load is over dimension, add fee from Table 1.

\section{TABLE 4. MISCELLANEOUS MOVES}

Overweight $2-5$ axle trucks carrying agricultural commodities including but not limited to corn, soybeans, wheat, oats, grain sorghum, canola, rice, livestock, insilage, fruits and vegetables.

Repeated overweight and/or over dimension moves directly across a highway, each vehicle.

$\$ 5.00$ per axle

$\$ 15.00$

Source:. Informational Forms, IDOT Oversize/Overweight Permit Office, Springfield IL http://www.dot.il.gov/road/infoforms.html 


\section{Appendix 4E. Kentucky- OW/OD Permit Fees and Specifications}

\begin{tabular}{|c|c|}
\hline Trip Permit & \$ \$60 ea \\
\hline Annual Permits & \\
\hline Non-divisible-less than $14 \mathrm{ft}$. wide & $\$ 250$ ea \\
\hline Non-divisible-14 ft. to $16 \mathrm{ft}$. wide & $\overline{\$ \$ 500 \mathrm{ea}}$ \\
\hline Steel-35 mile limit & $\$ 250$ ea \\
\hline Steel-statewide & 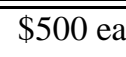 \\
\hline Farm-less than $14 \mathrm{ft}$. wide & $\$ 80$ ea \\
\hline Farm-14 ft. to $16 \mathrm{ft}$. wide & 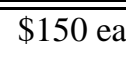 \\
\hline Industrial Haul & $\$ 20$ ea \\
\hline
\end{tabular}

The following dimensions are legal on Interstate and Designated Highways:

\begin{tabular}{|l|l|l|}
\hline Width: & $8 \mathrm{ft}$ 6in \\
\hline Height: & $13 \mathrm{ft}$ 6in \\
\hline Length: & 53ft trailer or load (overhang cannot exceed 5ft), any size tractor permitted \\
\hline
\end{tabular}

Once off the Designated Highway System, legal dimensions are:

\begin{tabular}{|l|l|l|}
\hline Width: & $8 \mathrm{ft}$ 0in \\
\hline Height: & $13 \mathrm{ft}$ 6in \\
\hline Length: & $65 \mathrm{ft}$ overall (tractor \& trailer) \\
\hline
\end{tabular}

Source: Overweight/Overdimensional Home page, Division of Motor Carriers Home Page http://dmc.kytc.ky.gov/owod/owod_permits_and_specs.htm 


\section{Appendix 4F. Michigan OW/OD Permits and Specifications}

\section{MAXIMUM LEGAL TRUCK LOADINGS AND DIMENSIONS}

\section{MAXIMUM OVERALL DIMENSIONS}

Width 96 inches

Width (designated highways). 102 inches

Height 13 feet, 6 inches

Length of semitrailer (including load) .53 feet

Length of a semitrailer (including load) NONDESIGNATED HIGHWAY .50 feet

Length of combination of truck-tractor and semitrailer with or without load No limitation

Length of any other vehicle with or without load (excluding impact absorbing bumpers) 40 feet

Units permitted in train Truck-tractor, semitrailer and trailer or truck- tractor and 2 semitrailers or truck and semitrailer or trailer. Length of a combination of truck-tractor, semitrailer, trailer or truck-tractor and 2 semitrailers or truck and semitrailer or trailer with or without load or pickup truck, semitrailer designed for recreational living purposes, and additional trailer/semitrailer (see exceptions) $65 \mathrm{ft}$ Semitrailers longer than 50 feet shall have a wheelbase of 37 feet to 41 feet (measured from the kingpin coupling to the center of the axles or to the center of the tandem axle assembly if equipped with 2 axles).

Semitrailers longer than 50 feet are limited to 3 axles.

Semitrailers longer than 50 feet shall operate on designated highways only.

Semitrailers and trailers shall be measured from the front vertical plane of the foremost transverse load supporting structure to the rearmost transverse load supporting structure.

Length shall not include safety and energy conservation devices including, but not limited to, impact absorbing bumpers, rear view mirrors, turn signal lamps, marker lamps, steps and hand holds for entry and egress, flexible fender extensions, mud flaps or splash and suppressant devices, load induced tire bulge, refrigeration or heating units, or air compressors. A device shall be excluded from a

determination of length only if it is not designed or used for the carrying of cargo.

Projection beyond front of vehicles 3 feet

Overhang beyond rear of vehicles Any amount is permissible if the legal length is not exceeded. However, if this overhang is 4 feet or more, there shall be displayed on the extreme rear of such a load a 12 - inch red square flag in the daytime and a red light or lantern at night. A combination of vehicles shall not exceed 11 axles.

Source: Maximum Legal Truck Loadings and Dimensions - Rules and Guidelines Michigan Department of Transportation, Lansing, MI. http://www.michigan.gov/documents/Loads_dim_87014_7.pdf

Continued... 


\section{PERMITS BY TYPE}

\section{Prefabricated Items (Structural Steel, Trusses, Tanks, Awnings, etc.)}

$\underline{\text { Single Trip Permits--Form } 2258}$

Limited to a maximum of:

16 feet in width

15 feet in height

150 feet in overall combination length

$\underline{\text { Extended Permits }}$ - Form 2266

Limited to a maximum of:

12 feet 6 inches in width

14 feet in height

85 feet in overall combination length

\section{$\underline{\text { Boats }}$}

Single Trip Permits Form 2258

Limited to a maximum of:

16 feet in width

15 feet in height

150 feet in overall combination length

Extended Permits - Form 2266

Limited to a maximum of:

12 feet 6 inches in width

14 feet in height

85 feet in overall combination length

\section{Construction Equipment (Bulldozers, Mobile Cranes, Crawler Cranes, etc.)}

\section{Single Trip Permits}

Limited to a maximum of:

16 feet in width

15 feet in height 
$\underline{\text { Extended Permits }}$ - Form 2282

Limited to a maximum of:

12 feet 6 inches in width

14 feet in height

85 feet in overall combination length

24,000 pounds per axle and a gross weight limitation of 150,000 pounds.

Empty rubber tired self-propelled scrapers, loaders, dozers, and two axle mobile cranes, limited in weight to the gross limitation of 150,000 pounds only (not to exceed 700 pounds per inch of tire width).

\section{$\underline{\text { Farm Equipment }}$}

\section{$\underline{\text { Single Trip Permits }}$}

Permits will be required for all movements of implements of husbandry when loaded onto a trailer. A permit is not required when farm equipment is being driven or towed.

Limited to a maximum of:

16 feet in width

15 feet in height

150 feet in overall combination length

$\underline{\text { Extended Permits }}$ - Form 2270

Permits will be required for all movements of implements of husbandry when not involved in normal farming operations and loaded. A permit is not required when farm equipment is being driven or towed.

Limited to a maximum of:

15 feet 6 inches in width

14 feet in height

80 feet in overall combination length

Continued... 


\section{Mobile Home Frames}

\section{Single Trip Permits}

Limited to a maximum of:

16 feet in width

80 feet in length of frame, excluding tongue

105 feet in overall combination length

The width of the load shall not exceed the width of the widest frame. Staggered loading in length not permitted.

\section{$\underline{\text { Extended Permits }}-$ Form 2272}

Limited to a maximum of:

12 feet in width

80 feet in length of frame, excluding tongue

95 feet in overall combination length

\section{$\underline{\text { Poles, Pipe \& Similar Type Loads }}$}

\section{$\underline{\text { Single Trip Permits }}$}

Limited to a maximum of:

16 feet in width

15 feet in height

150 feet in overall combination length

\section{$\underline{\text { Extended Permits }- \text { Form } 2268}$}

Limited to a maximum of:

8 feet in width

13 feet 6 inches in loaded height

85 feet in overall combination length

Continued... 


\section{PERMIT FEES}

Single Trip Permit - Form 2258 (this form is provided as a convenience-- Single Trip permit applications are submitted electronically via the MIPARS software)

- $\$ 15.00 \quad$ For a permit which is legal in weight.

- $\$ 50.00 \quad$ For a permit which is over legal axle weight limits.

\section{Extended Permits}

\begin{tabular}{|l|l|}
\hline Extended Permit Type & Click to Download Form Number \\
\hline Agricultural & Form 2270 \\
\hline Mobile Home & $\underline{\text { Form 2272 }}$ \\
\hline Construction & $\underline{\text { Form 2282 }}$ \\
\hline Milk & Form 2285 \\
\hline $\begin{array}{l}\text { Logs } \\
\text { Raw Forest-w/ Plates } \\
\text { Rubbish } \\
\text { Snow Removal }\end{array}$ & Form 2266 \\
Wrecker & \\
Miscellaneous & \\
\hline Pipe/Pole & \\
\hline
\end{tabular}

Application forms may also be downloaded from http://www.mdot.state.mi.us/webforms

Renewal Fees:

- \$30.00 for Legal Axle Weight-- Oversize Only

- $\$ 100.00$ for Overweight and/or oversize

New Applications:

Please Call: $\quad$ (517) 373-2120 for Fee Schedule

\section{Extended Permits (annual) are issued by mail from the Lansing office only}

Source: Moving Oversize or Overweight Vehicles and Loads - Rules and Guidelines, Michigan Department of Transportation, Lansing, MI. http://www.michigan.gov/documents/MDOT_MoveOS_OW_T2_92127_7.pdf 


\section{Appendix 4G. Ohio OW/OD Permits and Specifications}

$\underline{\text { OHIO }}$

\section{SPECIAL HAULING PERMIT FEE SCHEDULE Effective July 1, 2009}

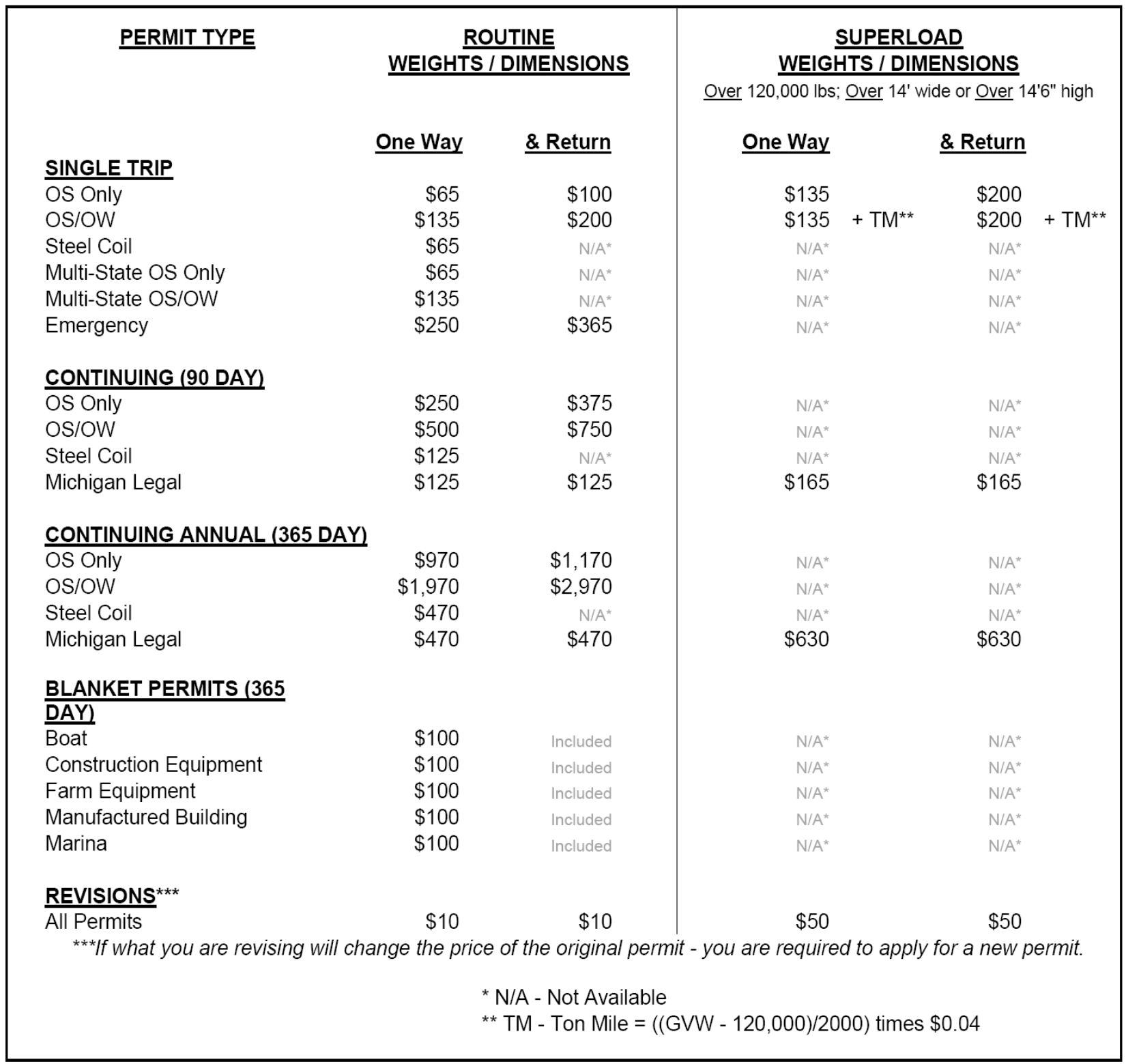

Source: Special Hauling Permits Section (Oversize/Overweight Vehicles and Loads).

Ohio Department of Transportation, Columbus, $\mathrm{OH}$.

http://www.dot.state.oh.us/Divisions/HighwayOps/Maintenance/Permits/Pages/default.aspx 


\section{Appendix 4H. Minnesota OW/OD Permits and Specifications}

\section{MINNESOTA}

\section{Annual and Seasonal Permit Chart}

\begin{tabular}{|c|c|c|c|c|c|c|}
\hline Permit Types & Permit \# & Fee & Width & Height & Length & Weight \\
\hline $\begin{array}{l}\text { Farm Implement Oversize Only } \\
\text { Farm machinery moved on one specific truck or truck- } \\
\text { trailer combination. }\end{array}$ & 69 & $\$ 24.00$ & $14^{\prime} 0$ & $13^{\prime} 6$ & $\begin{array}{c}45^{\prime} 0 \\
\text { Truck or } \\
75^{\prime} 0 \\
\text { combo }\end{array}$ & Legal \\
\hline $\begin{array}{l}\text { Farm Machinery Oversize Only } \\
\text { Farm machinery. }\end{array}$ & 7 & $\$ 120.00$ & $14^{\prime} 6$ & $14^{\prime} 0$ & $85^{\prime} 0$ & Legal \\
\hline $\begin{array}{l}\text { Farm Machinery Oversize Overweight } \\
\text { Farm machinery. }\end{array}$ & Multiple & * & $14^{\prime} 6$ & $14^{\prime} 0$ & $85^{\prime} 0$ & $\begin{array}{c}\operatorname{Max} \\
145,000\end{array}$ \\
\hline $\begin{array}{l}\text { Forest Products } \\
\text { Must be a } 6 \text { or more axle combination, consisting of a } \\
\text { truck tractor with a minimum } 3 \text { axles and a semi trailer } \\
\text { with minimum } 3 \text { axles or } 4 \text { axle truck with } 2 \text { axle pup } \\
\text { trailer. During Winter Weight Increase period potential } \\
\text { GVW is } 99,000 \text { lbs with proper axle spacings. } \\
\text { No travel on Interstate. Also includes finished forest } \\
\text { products such as paper, pulp, oriented strand board, } \\
\text { laminated strand lumber, hardboard, treated lumber, } \\
\text { untreated lumber, barrel staves }\end{array}$ & 73 & $\$ 300.00$ & $8^{\prime} 6$ & $13^{\prime} 6$ & $75^{\prime} 0$ & 90,000 \\
\hline $\begin{array}{l}\text { Harvest Weight Increase } \\
\text { (sugar beets, potatoes, carrots) } \\
\text { First haul from the field of harvest to the first point of } \\
\text { unloading up to } 88,000 \mathrm{lbs} \text {. only on US and TH highways } \\
\text { between October } 1 \mathrm{st} 12: 01 \mathrm{AM} \text { to November } 30 \text { th } 12: 00 \\
\text { PM. Vehicle must be registered to haul this increased } \\
\text { weight. No travel on Interstate. }\end{array}$ & 3 & $\$ 60.00$ & $8^{\prime} 6$ & $13^{\prime} 6$ & $75^{\prime} 0$ & 88,000 \\
\hline \begin{tabular}{|l|} 
Horse/Stock Trailers \\
Must be NEW going from Manufacturer to the dealer. \\
3 vehicle combo for cargo horse or stock trailers, towed \\
behind a truck tractor, truck or pickup (rated at $3 / 4$ ton or \\
above). All units must be empty. Trailers can not exceed \\
$28^{\prime} 6 "$ "long. 1st trailer must have fifth wheel hookup. \\
Travel only on NTN and MN Twin Trailer Routes.
\end{tabular} & 63 & $\$ 120.00$ & $8^{\prime} 6$ & $13^{\prime} 6$ & 75 & Legal \\
\hline $\begin{array}{l}\text { Job Oversize Only } \\
\text { Allows same type of non-divisible objects over one } \\
\text { designated route. Must be used by the same permit } \\
\text { user, wth same vehicle, similar size and weights, with } \\
\text { identical restrictions from/to one job site. Issued up to } 60 \\
\text { days. } \\
\text { Job Oversize Overweight } \\
\text { Single Trip Permit. "Damage Assement Fee" } X \text { number } \\
\text { of moves }+\$ 15.00 \text { fee }\end{array}$ & 75 & $\$ 36.00$ & Varies & Varies & Varies & Legal \\
\hline \begin{tabular}{|l|} 
Livestock \\
Overweight is only allowed for the following three types of \\
truck trailer combinations: (1) 3 axle truck tractor with a 3 \\
axle semitrailer, (2) 4 axle truck tractor with a 2 axle \\
"spread tandem" semitrailer, (3) 3 axle truck tractor with \\
a 3 axle "Two- Four-Two" with semitrailer. (Minimum \\
spacing between axle centers of the 1 st and 3rd axle of \\
the "two-four-two tridem" 9'1"). Max weights are 12,000 \\
on steer axles 17,000 on each drive axle, and 43,000 \\
total on the "two-four-two tridem" semtrailer with no \\
single axle over 20,000 . No travel on Interstate.
\end{tabular} & & $\$ 200.00$ & $8^{\prime} 6$ & $13^{\prime} 6$ & $75^{\prime} 0$ & 88,000 \\
\hline
\end{tabular}

Continued... 


\begin{tabular}{|c|c|c|c|c|c|c|}
\hline Permit Types & Permit \# & Fee & Width & Height & Length & Weight \\
\hline $\begin{array}{l}\text { Lowbed } \\
\text { Semi trailer that is over } 8^{\prime} 6 " \text { wide but less than } 9^{\prime} 0 " \text { wide. } \\
\text { Used for transporting farm machinery or construction } \\
\text { equipment only. }\end{array}$ & 49 & $\$ 120.00$ & $9^{\prime} 0$ & $13^{\prime} 6$ & $75^{\prime}$ & Legal \\
\hline $\begin{array}{l}\text { Mobile Crane } \\
\text { Does not include truck-mounted crane. }\end{array}$ & Multiple & * & $8^{\prime} 6$ & $14{ }^{\prime} 0$ & $48^{\prime}$ & $\begin{array}{c}\text { Max } \\
145,000\end{array}$ \\
\hline $\begin{array}{l}\text { Mobile Home } \\
\text { New and used homes. New homes for hire need a Drive } \\
\text { Away-In Transit plate. Used homes within Minnesota } \\
\text { require information on when taxes were paid, What } \\
\text { county they were paid in, Auditor \& Treasurer's name and } \\
\text { date. Storage sheds are also included in this annual. }\end{array}$ & 5 & $\$ 120.00$ & $14{ }^{\prime} 6$ & $13^{\prime} 6$ & $85^{\prime} 0$ & Legal \\
\hline $\begin{array}{l}\text { Non-Commercial Boat Hauler } \\
\text { Allows the owner of an oversized boat to haul on MN } \\
\text { State Trunk Highways. Issued only to the owner of Boat, } \\
\text { Trailer \& Vehicle pulling the trailer. }\end{array}$ & 79 & $\$ 60.00$ & $14{ }^{\prime} 6$ & $14{ }^{\prime} 0$ & $855^{\prime} 0$ & Legal \\
\hline $\begin{array}{l}\text { Pole Length Pulpwood } \\
\text { Transporting pole length pulpwood with a gross vehicle } \\
\text { weight of NOT more than } 82,000 \mathrm{lbs} \text { on six axles and } \\
\text { traveling only on non -Interstate Routes. }\end{array}$ & 53 & $\$ 60.00$ & $8^{\prime} 6$ & $13^{\prime} 6$ & $75^{\prime} 0$ & 82,000 \\
\hline $\begin{array}{l}\text { Rubbish Compactor } \\
\text { A } 2,3 \text {, or } 4 \text { axle motor vehicle having a device } \\
\text { permanently mounted on the Truck that is used } \\
\text { exclusively to compact refuse }(22,000 \text { single, } 38,000 \\
\text { tandem \& } 46,000 \text { tridem). }\end{array}$ & 59 & $\$ 85.00$ & $8^{\prime} 6$ & $13^{\prime} 6$ & $45^{\prime} 0$ & 62,000 \\
\hline $\begin{array}{l}\text { Snow Plow (Seasonal) } \\
\text { Allows vehicles with snowplow blades up to a maximum } \\
\text { of } 10 \text { ' wide between October } 1 \text { st and April 1st. }\end{array}$ & 89 & $\$ 60.00$ & $10^{\prime}$ & $13^{\prime} 6$ & $45^{\prime} 0$ & Legal \\
\hline $\begin{array}{l}\text { Studded Tire/ Mail Carrier (Seasonal) } \\
\text { Provides use of studded snow tires for rural mail carriers } \\
\text { of the United States Postal Service. They must provide } \\
\text { proof they are employed by the US Postal Service, } \\
\text { provide a map showing the delivery route, vehicle VIN } \\
\text { number, and description of the vehicle. No more than } \\
25 \% \text { of the total mileage on the applicant's delivery route } \\
\text { is allowed to be on paved roads. Permit is valid from } \\
\text { November 1st, and expires 12:01 AM April 16th the } \\
\text { following calendar year. }\end{array}$ & 29 & None & $\begin{array}{l}\text { Auto or } \\
\text { pickup } \\
8 ' 6\end{array}$ & $\begin{array}{l}\text { Auto or } \\
\text { pickup } \\
13^{\prime} 6\end{array}$ & $\begin{array}{l}\text { Auto or } \\
\text { pickup } \\
45^{\prime} 0\end{array}$ & Legal \\
\hline $\begin{array}{l}\text { Ten Percent Winter Weight Increase (Seasonal) } \\
10 \% \text { weight increase based on the freezing index each } \\
\text { winter. For Interstate Route travel only. Vehicle must be } \\
\text { registered to haul this increased weight. Can have } 10 \% \\
\text { overweight on Trunk Hwys without permit. }\end{array}$ & 13 & $\$ 60.00$ & $8^{\prime} 6$ & $13^{\prime} 6$ & $\begin{array}{l}45^{\prime} 0 \\
\text { truck or } \\
75^{\prime} 0 \\
\text { combo }\end{array}$ & 88,000 \\
\hline
\end{tabular}

Continued... 


\begin{tabular}{|c|c|c|c|c|c|c|}
\hline Permit Types & Permit \# & Fee & Width & Height & Length & Weight \\
\hline $\begin{array}{l}\text { Three Unit Permit (Grand Rapids to Duluth Permit) } \\
\text { Two 28'6" trailers, 108,000 GVW only on the following } \\
\text { Routes - US2 between Grand Rapids to Port of Duluth, } \\
\text { MN194 between US2 and US53, US } 53 \text { between } \\
\text { Virginia and Port of Duluth and US169 between Grand } \\
\text { Rapids and US53 at Virginia. No seasonal weight } \\
\text { increase allowed. }\end{array}$ & & $\$ 850.00$ & $8^{\prime} 6$ & $13^{\prime} 6$ & $\begin{array}{c}45^{\prime} 0 \\
\text { truck or } \\
75^{\prime} 0 \\
\text { combo }\end{array}$ & 108,000 \\
\hline $\begin{array}{l}\text { Tow Truck } \\
\text { Allows tow trucks to exceed weight \& length limitations of } \\
\text { MN Statutes, Chapter } 169 \text { when towing a disabled or } \\
\text { damaged vehicle to a place of repair or safekeeping. } \\
\text { Permit covers all tow trucks owned by the applicant. }\end{array}$ & & $\$ 300.00$ & $8^{\prime} 6$ & $13^{\prime} 6$ & $\begin{array}{c}\text { Not } \\
\text { restricted }\end{array}$ & $\begin{array}{c}\text { Not } \\
\text { restricted }\end{array}$ \\
\hline $\begin{array}{l}\text { Two Unit Permit } \\
\text { Semi-trailer not to exceed } 53^{\prime} \text { with } 43^{\prime} \text { kingpin setting. } \\
\text { Only on routes - US2 between Grand Rapids and Port of } \\
\text { Duluth, MN194 between US } 2 \text { and US53, US53 between } \\
\text { Virginia and Port of Duluth or US169 between Grand } \\
\text { Rapids and US53 at Virginia. } \\
90,000 \text { on } 6 \text { axles } 97,000 \text { on } 7 \text { axles } \\
98,000 \text { seasonal weight increase. }\end{array}$ & & $\$ 850.00$ & $8^{\prime} 6$ & $13^{\prime} 6$ & $\begin{array}{c}45^{\prime} 0 \\
\text { Truck or } \\
75^{\prime} 0 \\
\text { combo }\end{array}$ & $\begin{array}{c}90,000 \text { on } \\
6 \text { axles } \\
97,000 \text { on } \\
7 \text { axles }\end{array}$ \\
\hline
\end{tabular}

* See Annual Overweight list below

\begin{tabular}{|c|}
\hline 90M LBS, GVW $=\$ 200.00$ \\
\hline $100 \mathrm{M}$ LBS, GVW $=\$ 300.00$ \\
\hline $110 \mathrm{M}$ LBS, GVW $=\$ 400.00$ \\
\hline $120 \mathrm{M}$ LBS, GVW $=\$ 500.00$ \\
\hline $130 \mathrm{M}$ LBS, GVW $=\$ 600.00$ \\
\hline $140 \mathrm{M}$ LBS, GVW $=\$ 700.00$ \\
\hline $145 \mathrm{M}$ LBS, GVW $=\$ 800.00$ \\
\hline
\end{tabular}

Overweight Permits do not automatically increase vehicle registered weight. Permittee must increase vehicle registered weight with Dept. of Public Safety (Driver and Vehicle Services)

Source: Oversize/Overweight Permits, Minnesota State Permits for Commercial and Private Vehicles,

Minnesota Department of Transportation, St. Paul, MN http://www.dot.state.mn.us/cvo/oversize/annualseasonalpermitchart.pdf 


\section{Appendix 4 I. Wisconsin OW/OD Permits and Specifications WISCONSIN}

\section{Single Trip Permit}

Maximum size and weight for which a single trip permit may be granted:

Length - Single vehicle $50 \mathrm{ft}$.

Mobile crane $60 \mathrm{ft}$.
Weight Limitation

Steering Axle

Any Other Axle

Additional weight limitations

may be imposed by route.

\section{Gross \\ Weight \\ In Pounds \\ 20,000 \\ 35,000}

The overall length, width and height of other loads depends on type of load.

If the spacing between adjacent axles is less than 42 inches, the axle can carry no more than a single axle.

\section{Mobile Homes and/or Modular Building Sections}

Maximum size for which a single trip permit may be granted:

100 feet 80 feet

\section{Insurance Requirements}

Mobile Home or Modular Only

Overall Width limitations

will be determined by route.

The permittee shall have at least the following insurance coverage in full force and effect on the vehicle and load designated in the permit while operating on the public highway.

Bodily Injury Liability - each person

Bodily Injury Liability - each accident

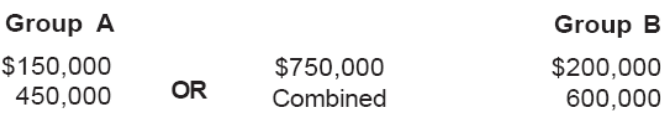

Property Damage Liability - each accident

450,000

Combined

Single Limit

400,000

OR $\begin{gathered}\$ 1,000,000 \\ \text { Combined }\end{gathered}$

Single Limit

Group A Applies when the permitted load does not exceed 12 feet in width, $131 / 2$ feet in height, or 100 feet in length and does not exceed statutory gross weight limits by more than $25 \%$.

Group B Applies when the permitted load exceeds the size and weight limitations in Group A.

\section{Charges}

1. The fee shall accompany the application and shall be retained by the Department of Transportation only if a permit is issued.

2. No charge shall be made for a change when an error was made by the issuing authority.

3. All charges for the transmission of an application or a permit, other than by U.S. Mail, are in addition to the permit fee and are the responsiblity of the applicant.

4. No charge shall be made to any state department, county, town, municipality, or any branch of the United States Government or the Armed Services for any type of oversize/overweight permit.

5. A charge of $\$ 10.00$ per district will be made when, by reason of the size or weight of the vehicle or load, the route must be reviewed by a regional highway office.

6. A charge of $\$ 10.00$ per review will be made when, by reason of the gross weight of the vehicle and load, a review is necessary of specific highway structures.

7. Permit fees are established by s.348.25 Wisconsin Statutes and Wisconsin Administrative Code Trans. 250.

8. Make check payable to: Registration Fee Trust

\section{Fee Chart}

Overlength Only

$\$ 15.00$

Overwidth OR Overheight (may include Overlength) 20.00

Overwidth AND Overheight (may include Overlength) 25.00

Overweight (Includes any oversize)

$\begin{array}{rr}0-90,000 \text { lbs. } & \$ 20.00 \\ 90,001-100,000 \text { lbs. } & 35.00 \\ 100,001-110,000 \text { lbs. } & 45.00 \\ 110,001-120,000 \text { lbs. } & 55.00 \\ 120,001-130,000 \text { lbs. } & 65.00 \\ 130,001-140,000 \text { lbs. } & 75.00 \\ 140,001-150,000 \text { lbs. } & 85.00 \\ 150,001-\quad \text { and up } & 85.00 \text { plus } \$ 10.00 \text { per } 10,000 \text { lbs. or fraction thereof }\end{array}$

Continued... 
Direct online self-issuance or renewal of permit types AA and RF is now available.

www.dot.wisconsin.gov/business/carriers/osowgeneral.htm

Contact us at oversize-permits.dmv@dot.state.wi.us for instructions.

Nondivisible load permits issued under s.348.27 Wis. Stats. include permit types Annual (AA), Project (AP), and Mobile Home/Modular Building

Sections $(\mathrm{MH})$. Permits will be issued for power units only.

$\begin{array}{lccc}\text { Size Limitations } & \text { Vehicles \& Loads } & \begin{array}{c}\text { Nondivisible Loads } \\ \text { Mobile Crane }\end{array} & \text { Mobile Home/Modular Building Section } \\ \text { Single Vehicle Length } & 50^{\prime} & 60^{\prime} & 80^{\prime} \\ \text { Vehicle Combination Length } & 100^{\prime} & 75^{\prime} & 100^{\prime} \\ \text { Overall Width } & 14^{\prime} & 14^{\prime} & 15^{\prime} \text { at the Box; 16' at the Roof } \\ \text { Overall Height } & 16^{\prime} & 16^{\prime} & 15^{\prime}\end{array}$

\section{Gross Weight Limitations}

Single Axle Limit = 20,000 Lbs.; Single Axle (4 Tires) Limit = 30,000 Lbs.; 2 - Axle Tandem (4 or 8 Tires) $=55,000$ Lbs.; 2 - Axle Tandem (16 Tires) $=60,000$ Lbs.; 3 - Axle Tandem $=70,000$ Lbs.; 4 - Axle Tandem $=80,000$ Lbs.

The total gross load permitted on any combination of single axles or tandem axle groups shall be reduced in proportion as the spacing between adjacent axles is less than 18 feet. Tandem axle means any 2 consecutive axles whose centers are 42 or more inches apart and which are individually attached to or articulated from a common attachment to the vehicle.

\section{Insurance Requirements}

Bodily Injury Liability - each person

Bodily Injury Liability - each accident

Property Damage Liability - each accident
Group A

$\begin{array}{rr}\$ 150,000 & \$ 750,000 \\ 450,000 & \text { OR } \\ 300,000 & \text { Combined } \\ \text { Single Limit }\end{array}$

Group B

$\begin{array}{rr}\$ 200,000 & \begin{array}{r}\$ 1,000,000 \\ \text { Combined } \\ 400,000\end{array} \\ \text { Single Limit }\end{array}$
length, and do not exceed statutory gross weight limits by more than $25 \%$.

Group B Applies when permit is issued for any dimension in excess of those for Group A.

\section{Permit Fees}

\begin{tabular}{|c|c|c|c|c|c|c|c|c|c|c|}
\hline Onl & 12 & I IVIOH & & $9 \mathrm{Mc}$ & 8 Month & 7 Month & 6 Month & 5 Month & 4 Month & $3 \mathrm{Mc}$ \\
\hline & & $\Phi G$ & $\mathbb{E}$ & & & & & & & \\
\hline and/or & c & 00 & & & & & & & 45.00 & \\
\hline
\end{tabular}
Heightand/or Length

If Overweight OR Overweight and Oversize - Round weight up to the next ten thousand pound increment. For example, if weight is 93,000 pounds, round upward to 100,000 weight increment to determine fees.

$\begin{array}{rrrrrrrrrrr}\text { Up to 90,000 Lbs } & 200.00 & 198.33 & 181.67 & 165.00 & 148.33 & 131.67 & 115.00 & 98.33 & 81.67 & 65.00 \\ \text { 100,000 Lbs } & 350.00 & 335.83 & 306.67 & 277.50 & 248.33 & 219.17 & 190.00 & 160.83 & 131.67 & 102.50 \\ \text { 110,000 Lbs } & 450.00 & 427.50 & 390.00 & 352.50 & 315.00 & 277.50 & 240.00 & 202.50 & 165.00 & 127.50 \\ \text { 120,000 Lbs } & 550.00 & 519.17 & 473.33 & 427.50 & 381.67 & 335.83 & 290.00 & 244.17 & 198.33 & 152.50 \\ \text { 130,000 Lbs } & 650.00 & 610.83 & 556.67 & 502.50 & 448.33 & 394.17 & 340.00 & 285.83 & 231.67 & 177.50 \\ \text { 140,000 Lbs } & 750.00 & 702.50 & 640.00 & 577.50 & 515.00 & 452.50 & 390.00 & 327.50 & 265.00 & 202.50 \\ \text { 150,000 Lbs } & 850.00 & 794.17 & 723.33 & 652.50 & 581.67 & 510.83 & 440.00 & 369.17 & 298.33 & 227.50 \\ \text { 160,000 Lbs } & 950.00 & 885.83 & 806.67 & 727.50 & 648.33 & 569.17 & 490.00 & 410.83 & 331.67 & 252.50 \\ \text { 170,000 Lbs } 1050.00 & 977.50 & 890.00 & 802.50 & 715.00 & 627.50 & 540.00 & 452.50 & 365.00 & 277.50\end{array}$

Procedure to Calculate Fees

1. Choose the effective and expiration dates you want for the permit for which you are applying.

2. Count up the number of months in the desired permit, from the beginning day to the ending day. When figuring "months," do not use calendar months. The month begins on the effective date of the permit. For example, if you want the permit to become effective May 23, then May 23 to June 22 is counted as exactly 1 month.

3. If the number of months in the desired permit is not exact, round upward to the next whole number of months. For example, if you intend the permit to become effective 5-16-2005 and to expire 1-21-2006, it would be valid for 8 months 6 days. Rounding upward, the desired permit would be subject to the 9 month charge in the fee scale.

4. Refer to the fee chart above to determine fees.

Instructions

1. Make checks payable to: Registration Fee Trust.

2. No charge shall be made to any state department, county, town, municipality, or any branch of the United States Government or the Armed Services for any type of oversize/overweight permit.

3. The fee must accompany the application and will be retained by the Department only if a permit is issued.

4. A renewal notice will be mailed to you in month prior to permit expiration.

5. No charge is made for a transfer of permit from one vehicle to another. A new application must be submitted, stating this is a transfer from permit \#

6. Submit completed form MV2612 when adding a new vehicle.

7. If you have questions regarding permit applications, call (608) 266-7320.

Source: Oversize-overweight permits, Wisconsin Department of Transportation, Madison, WI. http://www.dot.wisconsin.gov/business/carriers/osowgeneral.htm 


\section{Appendix 4 J. Missouri OW/OD Permits and Specifications}

\section{MISSOURI}

\section{Oversize/Overweight Permit Requirements}

Single Trip Routine Move - Valid for 7 days

Refer to Vehicle Route Map available on line at www.modot.org/mcs or contact Motor Carrier Services at 800-877-8499 for legal and maximum permittable limits

\section{Commercial Zones}

(Dark Purple - all routes and Light Purple all routes except Interstate)

\section{Dimension}

Width

Height

Length - Trailer \& Load

Truck-tractor semi-trailer combination

Length - Overall

Truck-tractor semi-trailer combinations

Length - Truck-trailer combinations

Length - Auto/boat transporter

Length - Towed units

Length - Single units

Weight - not to exceed 22,400 lbs per axle
Legal

8'6"

$15^{\prime}$

$53^{\prime}$

N/A

$65^{\prime}$

$75^{\prime}$ plus $3^{\prime}$ front \& 4'

75 rear overhang

$65^{\prime}$

$45^{\prime}$

N/A
Maximum Permittable $16^{\prime}$

$16^{\prime}$

$\mathrm{N} / \mathrm{A}$

$150^{\prime}$

$\mathrm{N} / \mathrm{A}$

N/A

$150^{\prime}$

$60^{\prime}$

None

Interstate and Designated Highway System Or Within 10 Air Miles

(Not in a Commercial Zone)

\section{Dimension}

Width

Height

Length - Trailer \& Load

Truck-tractor semi-trailer combination

Length - Overall Truck-tractor semi-trailer combinations

Length - Truck-trailer combinations

Length - Auto/boat transporter

Length - Towed units

Length - Single units

Weight - Truck-tractor semi-trailer combinations

Weight - Specialized equipment

\section{Legal}

$8^{\prime} 6^{\prime \prime}$

$14^{\prime}$

$53^{\prime}$

N/A

$65^{\prime}$

$75^{\prime}$ plus $3^{\prime}$ front \& $4^{\prime}$

$65^{\prime}$

$45^{\prime}$

80,000 lbs*

See pages $33-35 \quad 152,000 \mathrm{lbs}$
Maximum Permittable

$16^{\prime}$

$16^{\prime}$

$\mathrm{N} / \mathrm{A}$

$150^{\prime}$

$\mathrm{N} / \mathrm{A}$

N/A

$150^{\prime}$

$60^{\prime}$

$160,000 \mathrm{lbs}$

*If hauling livestock on US36 between St Joseph and US65 and US65 to the lowa State Line $85,500 \mathrm{lbs}$ is legal 


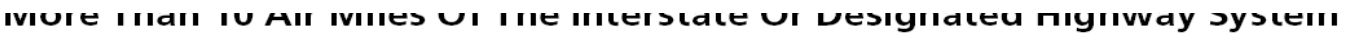
(Pink colored areas on Vehicle Route Map)

\begin{tabular}{|c|c|c|}
\hline Dimension & Legal & $\begin{array}{l}\text { Maximum } \\
\text { Permittable }\end{array}$ \\
\hline Width & $8^{\prime} 6 "$ & $16^{\prime}$ \\
\hline Height & $13^{\prime} 6^{\prime \prime}$ & $16^{\prime}$ \\
\hline $\begin{array}{l}\text { Length - Trailer \& Load } \\
\text { Truck-tractor semi-trailer combination }\end{array}$ & $\mathrm{N} / \mathrm{A}$ & $N / A$ \\
\hline $\begin{array}{l}\text { Length - Overall } \\
\text { Truck-tractor semi-trailer combinations }\end{array}$ & $60^{\prime}$ & $150^{\prime}$ \\
\hline Length - Truck-trailer combinations & $65^{\prime}$ & $N / A$ \\
\hline Length - Auto/boat transporter & $75^{\prime}$ plus $3^{\prime}$ front \& $4^{\prime}$ & $\mathrm{N} / \mathrm{A}$ \\
\hline Length - Towed units & 65 , rear overhang & $150^{\prime}$ \\
\hline Length - Single units & $45^{\prime}$ & $60^{\prime}$ \\
\hline $\begin{array}{l}\text { Weight - Truck-tractor semi-trailer } \\
\text { combinations }\end{array}$ & $80,000 \mathrm{lbs}$ & $160,000 \mathrm{lbs}$ \\
\hline Weight - Specialized equipment & See pages $33-35$ & $152,000 \mathrm{lbs}$ \\
\hline
\end{tabular}

More Than 10 Air Miles Of The Interstate Or Primary Highway System (yellow colored areas on the Vehicle Route Map)

Dimension

Width

Height

Length - Trailer \& Load

Truck-tractor semi-trailer combination Length - Overall

Truck-tractor semi-trailer combinations

Length - Truck-trailer combinations

Length - Auto/boat transporter

Length - Towed units

Length - Single units

Weight - Truck-tractor semi-trailer

combinations

Weight - Specialized equipment

\section{Legal}

8'6"

$13^{\prime} 6^{\prime \prime}$

$53^{\prime}$

N/A 150'

$55^{\prime}$

$75^{\prime}$ plus $3^{\prime}$ front \& 4'

$55^{\prime}$

$45^{\prime}$

$80,000 \mathrm{lbs}$

See pages $33-35 \quad 152,000$ lbs

Legal Gross Weight is 80,000 lbs. unless specialized equipment. Refer to pages $33-35$ of the Oversize and Overweight Regulation Handbook for specialized equipment legal and permittable weights. Maximum permitted weight is $20,000 \mathrm{lbs}$ on a single axle, $46,000 \mathrm{lbs}$ on a tandem axle group, $60,000 \mathrm{lbs}$ on a triple axle group and $72,000 \mathrm{lbs}$ on a quadrum axle group.

Requirements To Obtain Single Trip Permit

- Year, make, license number and VIN of power unit and trailer and any other hauling units

- Load description, make, serial number and dimensions of load.

- Overall dimensions and length of trailer \& load if a truck-tractor semi-trailer combination.

- Individual or group axles weights

- Individual axles spacings (center to center)

- Origin of route

- Destination of route

- Requested route

- Date of movement

- $\$ 750,000$ combined single limit automobile liability insurance

Continued... 


\section{PERMITS FEES}

1. Single trip oversize permits including pre-issue $-\$ 15$;

2. Single trip oversize permits in excess of sixteen feet (16') wide, sixteen feet (16') high, or one hundred fifty feet $(150$ ') long - $\$ 15$ plus $\$ 250$ movement feasibility fee;

3. Multi-stop oversize permit— $\$ 25$ (farm implements only);

4. Single trip overweight permits up to and including one hundred sixty thousand $(160,000)$ pounds gross weight $-\$ 15$ plus $\$ 20$ per each ten thousand $(10,000)$ pounds in excess of legal gross weight;

5. Single trip overweight permits in excess of one hundred sixty thousand $(160,000)$ pounds gross weight $-\$ 15$ plus $\$ 20$ per each ten thousand $(10,000)$ pounds in excess of legal gross weight plus bridge and roadway analysis fee of $\$ 425$ for each permit for moves from 0-50 miles in length; \$625 for 51-200 miles; $\$ 925$ for over 200 miles. Identical permit applications with identical vehicle configurations will only be charged one bridge and roadway analysis fee if the original bridge study is less than thirty (30) days old for loads in excess of three hundred thousand $(300,000)$ pounds and if the original bridge study is less than sixty (60) days old for loads weighing less than three hundred thousand $(300,000)$ pounds. An additional four hundred twenty-five dollar (\$425) bridge study fee will be charged if the applicant modifies dimensions or weights on an application and a new bridge analysis is required after the original analysis has been completed;

6. Annual blanket emergency overweight permit (round trip): $\$ 624$ (fee will be prorated quarterly);

7. Annual blanket oversize permit (single commodity): $\$ 128$ (fee will be prorated quarterly);

8. Annual blanket oversize permit (multiple commodity): $\$ 400$ (fee will be prorated quarterly);

9. Annual blanket overweight well drillers or concrete pump truck permit: $\$ 300$ (fee will be prorated quarterly);

10. Thirty (30)-day blanket permit: $\$ 300$;

11. Project permit: $\$ 125$;

12. Highway crossing permit: $\$ 250$;

13. Noncommercial building movement (in excess of routine dimensions): $\$ 265$;

\section{Single Trip Commercial Zone Bridge Analysis \$265; and}

15. Permit amendment fee- $\$ 2$. Single trip permits may only be amended within two (2) business days of permit start date. The start date and any other component will be amended if permit effective date is in the future. The permittee, origin, destination, and/or commodity being hauled/towed will not be amended if the permit is already in effect. Annual blanket permits may be amended one time throughout the year for truck make and/or license. 
(F) Fees shall not be required for permits covering the movement of vehicles and loads owned and operated by governmental subdivisions or agencies.

(G) Permits may be applied for and picked up during regular business hours of 7:30 a.m. to 4:00 p.m. Monday through Friday except holidays. Telephone applications are accepted from 7:00 a.m. until 5:00 p.m. at (800) 877-8499 or (573) 751-7100 Monday through Friday except holidays. Internet access is also available twenty-four (24) hours a day, seven (7) days a week.

Source: Oversize/Overweight Permits Regulations, Motor Carrier Services, Missouri Department of Transportation, Jefferson City, MO.

http://www.modot.mo.gov/mcs/documents/2009OSOWRegBook-lowres.pdf 
APPENDIX 4K. IOWA OW/OD PERMITS AND SPECIFICATIONS

$\underline{\text { IOWA }}$

\begin{tabular}{|c|c|c|c|c|c|}
\hline Permit Type & Single Trip & & Annual & $\begin{array}{c}\text { Annual } \\
\text { Oversize/Overweight }\end{array}$ & Multi-Trip \\
\hline Cost & $\$ 10$ & & $\$ 25$ & $\$ 300$ & $\$ 200$ \\
\hline Axle Weight & $\begin{array}{c}20,000 \mathrm{lbs} \\
\text { per axle } \\
\text { *See exception }\end{array}$ & & 000 lbs. per axle & $\begin{array}{l}20,000 \mathrm{lbs} \\
\text { per axle }\end{array}$ & $\begin{array}{l}20,000 \mathrm{lbs} \\
\text { per axle }\end{array}$ \\
\hline Gross Weight & No limit & & $80,000 \mathrm{lbs}$ & $156,000 \mathrm{lbs}$ & $156,000 \mathrm{lbs}$ \\
\hline Height & No limit & $13^{\prime} 10^{\prime \prime}$ & 15 '5" & $155^{\prime \prime}$ & Unlimited \\
\hline Length & No limit & $120^{\prime}$ & $120^{\prime}$ & $120^{\prime}$ & $120^{\prime}$ \\
\hline Width & No limit & $12^{\prime} 5^{\prime \prime}$ & $16^{\prime}$ & $13^{\prime} 5 "$ & $16^{\prime}$ \\
\hline Interstate Travel & Allowed & Allowed & Allowed & \begin{tabular}{|c|} 
No interstate highway travel over \\
$80,000 \mathrm{lbs}$. \\
\end{tabular} & Allowed \\
\hline Routing & MCS routing required & $\begin{array}{l}\text { MCS } \\
\text { routing } \\
\text { not } \\
\text { required } \\
\end{array}$ & $\begin{array}{l}\text { MCS routing required when } \\
\text { loads over } 14 \text { ' } 6 \text { " wide. MCS } \\
\text { routing required when loads are } \\
\text { over } 50 \text {-mile radius unless } \\
\text { route continues on at least } \\
4 \text {-lane roads. }\end{array}$ & MCS routing not required & $\begin{array}{l}\text { Carrier provides route } \\
\text { and DOT verifies. } \\
\text { Load can change, } \\
\text { configuration cannot. }\end{array}$ \\
\hline Valid & 1 trip in 5 days & & months from month issued & 12 months from issued & 60 days \\
\hline $\begin{array}{l}\text { Construction } \\
\text { Equipment }\end{array}$ & $\begin{array}{c}\text { Allowed up to } 36,000 \\
\text { lbs. single axle; } \\
126,000 \text { gross weight } \\
\text { with qualifying tires }\end{array}$ & $\begin{array}{l}\text { Allowe } \\
80,0001\end{array}$ & $\begin{array}{l}\text { d up to } 36,000 \mathrm{lbs} \text {. single axle; } \\
\text { os. gross weight with qualifying } \\
\text { tires. }{ }^{* *}\end{array}$ & $\begin{array}{c}\text { Allowed up to } 36,000 \mathrm{lbs} \text {. single } \\
\text { axle; } 126,000 \mathrm{lbs} \text {. gross weight } \\
\text { with qualifying tires."* }\end{array}$ & $\begin{array}{l}\text { Allowed up to } 36,000 \\
\text { Ibs. single axle; } 126,000 \\
\text { gross weight with } \\
\text { qualifying tires }\end{array}$ \\
\hline $\begin{array}{l}\text { Carrier Route } \\
\text { Check }\end{array}$ & None & None & None & $\begin{array}{l}\text { - Construction and embargo maps } \\
\text { - Vertical clearance maps } \\
\text { - } 156 \text { Kip map } \\
\text { - Check with DOT to ensure no } \\
\text { changes }\end{array}$ & None \\
\hline $\begin{array}{l}\text { se permits a fe valkd } \\
\text { n indivisible vehick }\end{array}$ & for movementit on state an & & punty and eity per mils must be obta & $\begin{array}{l}\text { d separately. "Exoeption: Cranes with pne } \\
\text { orly; and travel is allowed on the intersta } \\
4.4 \text {. Whicles operating under an anmual }\end{array}$ & $\begin{array}{l}\text { watic tires moeting the defirition } \\
\text { system, "Exception: Formula } \\
\text { rsize/ overweight permit can }\end{array}$ \\
\hline
\end{tabular}

Source: Truck Information Guide 2008-2009 Edition, Office of Motor Carrier Services and Office of Motor Vehicle Enforcement, Iowa Department of Transportation, Des Moines, IA.

http://www.iamvd.com/omve/truckguide.pdf 


\section{APPENDIX 5: THE SPECIAL CASE OF OREGON}

In Oregon, the Motor Carrier Transportation Division (MCTD) issues single-trip and annual variance permits for overweight, over-height, over-width, over-length, and other unusual truck characteristics. The permits are used with appropriate routing plans, road restriction information, and other permit conditions. Permits and routing cover state and federal highways. The division issues approximately 100,000 complex single-trip permits each year and manages the work of private parties that process requests for about 50,000 continuous, annual variance permits each year (www.oregon.gov/ODOT/MCT/OD.shtml). The state participates in the Western Regional Permit Agreement that makes it possible for truckers to obtain permits for travel in nine other states.

Truckers will need an over-dimension variance permit whenever their vehicle combination exceeds maximum size and/or weight limits. A permit is also needed to haul any single, non-divisible load for which any one of the following conditions apply:

- Width of the load or hauling equipment exceeds 8 feet, 6 inches

- Height of vehicle or vehicle combination and load exceeds 14 feet

- Any single axle weight exceeds 20,000 pounds

- Any tandem axle weight exceeds 34,000 pounds

- Gross combination weight exceeds 80,000 pounds

- Front overhang exceeds 4 feet beyond the front bumper of the vehicle

- Load greater than 40 feet, exceeding 5 feet beyond the end of the semi-trailer, or load less than or equal to 40 feet, exceeding 1/3 of the wheelbase of the combination, whichever is less

- Gross weight of a group of axles exceeds those set forth in the state's legal weight table

- Vehicle combination length exceeds those authorized on state's legal dimensions table.

\section{Road Use Assessment Fees}

Table "A" presents the mileage tax rates for weights $80,000 \mathrm{lbs}$ or less. Table "B" presents the same information for all types of fuel for vehicles over $26,000 \mathrm{lbs}$. Table " $\mathrm{C}$ " presents the fees for single-trip, non-divisible loads 98,001- to 900,000 lbs. maximum gross weight. In Table " $\mathrm{C}$ ", the road use assessment fee takes the place of the weight-mile tax for the loaded portion of non-divisible hauls. The fee is 5.7 cents per equivalent single-axle load (ESAL) mile traveled. These fees are expressed in terms of permit gross weight and number of axles. As with the weight-mile tax rates in Table "B", carriers are assessed a lower per-mile charge if they use greater numbers of axles at any given gross weight. 


\section{MILEAGE TAX RATES}

\section{INSTRUCTIONS FOR TABLE "A":}

1. Use these rates only when operating at declared weight(s) of 80,000 pounds or less. Use table "B" rates for operations over 80,000 pounds.

2. To compute the tax, select the weight group that includes the declared weight of your vehicle. Multiply your Oregon taxable miles times the rate listed for the weight group to calculate the amount of tax due. Taxable miles in Oregon includes all miles driven in Oregon on roads accessible to the public. If returning empty, use the same declared weight and rate as when loaded.

You may claim a credit if you paid Oregon state fuel tax on fuel for a vehicle subject to weight-mile tax. The deduction must be for the reporting period that you used the fuel. Credits for previous reporting periods will not be granted until time of audit. You must attach copies of fuel invoices to the highway-use tax report.

See Instructions for Filing Highway-Use Tax Reports available on ODOT's Web site for information required to be included on fuel receipts, for claiming fuel tax credit on bulk fuel purchases, other record keeping requirements, and tax reporting information.

www.odot.state.or.us/trucking/regis/forms.htm

TABLE “A” FOR ALL TYPES OF FUEL (OVER 26,000 LBS)

\begin{tabular}{|c|c|c|c|c|c|}
\hline $\begin{array}{l}\text { COLUMN A } \\
\text { WEIGHT } \\
\text { GROUP }\end{array}$ & $\begin{array}{c}\text { COLUMN B } \\
\text { MILLS } \\
\text { (1/10 OF } 1 \text { CENT) } \\
\text { PER MILE } \\
\end{array}$ & $\begin{array}{c}\text { COLUMN C } \\
\text { DOLLARS PER MILE } \\
\text { DECIMAL } \\
\text { FRACTION }\end{array}$ & $\begin{array}{c}\text { COLUMN A } \\
\text { WEIGHT } \\
\text { GROUP }\end{array}$ & $\begin{array}{c}\text { COLUMN B } \\
\text { MILLS } \\
\text { (1/10 OF } 1 \text { CENT) } \\
\text { PER MILE } \\
\end{array}$ & $\begin{array}{c}\text { COLUMN C } \\
\text { DOLLARS PER MILE' } \\
\text { DECIMAL } \\
\text { FRACTION } \\
\end{array}$ \\
\hline $26,001-28,000$ & 40.0 & .0400 & $52,001-54,000$ & 66.9 & .0669 \\
\hline $28,001-30,000$ & 42.4 & .0424 & $54,001-56,000$ & 69.4 & .0694 \\
\hline $30,001-32,000$ & 44.3 & .0443 & $56,001-58,000$ & 72.3 & .0723 \\
\hline $32,001-34,000$ & 46.3 & .0463 & $\begin{array}{l}58,001-60,000 \\
60,001-62,000\end{array}$ & $\begin{array}{l}75.6 \\
79.5\end{array}$ & $\begin{array}{l}.0756 \\
.0795\end{array}$ \\
\hline $34,001-36,000$ & 48.1 & .0481 & & & \\
\hline $36,001-38,000$ & 50.6 & .0506 & $62,001-64,000$ & 83.9 & .0839 \\
\hline $38,001-40,000$ & 52.5 & .0525 & $64,001-66,000$ & 88.7 & .0887 \\
\hline $40,001-42,000$ & 54.4 & .0544 & $\begin{array}{l}66,001-68,000 \\
68,001-70,000\end{array}$ & $\begin{array}{r}95.0 \\
101.7\end{array}$ & $\begin{array}{l}.0950 \\
.1017\end{array}$ \\
\hline $42,001-44,000$ & 56.4 & .0564 & $70,001-72,000$ & 108.4 & .1084 \\
\hline $44,001-46,000$ & 58.3 & .0583 & & & \\
\hline $46,001-48,000$ & 60.2 & .0602 & $72,001-74,000$ & 114.6 & .1146 \\
\hline $48,001-50,000$ & 62.2 & .0622 & $74,001-76,000$ & 120.5 & 1205 \\
\hline \multirow[t]{3}{*}{$50,001-52,000$} & 64.5 & .0645 & $76,001-78,000$ & 126.3 & .1263 \\
\hline & & & $78,001-80,000$ & 131.6 & 1316 \\
\hline & & & 80,001 AND OVEF & \multicolumn{2}{|c|}{ USE TABLE B } \\
\hline
\end{tabular}

${ }^{\star}$ NOTE - Column C converts mills per mile to dollars per mile by moving the decimal point three places to the left. Multiply the decimal fraction by the Oregon Taxable Miles for the amount of tax due for each weight.

\section{COLUMNA COLUMN B $\quad \underline{\text { COLUMN C }}$}

EXAMPLES:

32,000

80,000

131.6
.0443

.1316

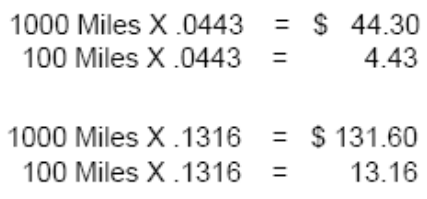

Source: http://www.odot.state.or.us/forms/motcarr/reg/9225.pdf 
OREGON DEPARTMENT OF TRANSPORTATION MOTOR CARRIER TRANSPORTATION DIVISION 550 CAPITOL ST NE

SALEM OR $97301-2530$

(503) 378-6699

\section{MILEAGE TAX RATES}

INSTRUCTIONS FOR TABLE "B":

1. Use these rates only when operating at declared weight(s) over $\mathbf{8 0 , 0 0 0}$ pounds. Empty returns are paid at the same declared weights as when loaded. Raising a lift axle is not a change in configuration and does not constitute a change in rate. These rates apply to motor vehicles that are issued or required to obtain an annual highway over-dimension permit to operate with a combined weight of 80,001 pounds or more (extended weight or heavy haul).

2. Your weight should be declared at the highest weight you intend to operate. You must pay the tax for all miles over 80,000 pounds at the tax rate for this weight. You may continue to declare and report tax on multiple weights if you use different trailer combinations. If you have a declared weight over 80,000 pounds, you must also have a declared weight at 80,000 pounds. Each trip operated at 80,000 pounds or under is paid at Table "A" rates.

3. To compute the tax, select the weight group that includes the declared weight of your vehicle, then go to the column with the correct number of axles. The rate where the columns intersect is the tax rate in mills (1/10 of 1 cent). Convert the mill rate to dollars per mile (see examples below the chart). Multiply your Oregon taxable miles times the rate to calculate the amount of tax due. Taxable miles in Oregon includes all miles driven in Oregon on roads accessible to the public.

4. Heavy haul operations over 98,000 pounds pay road use assessed fees (RUAF) separately to the ODOT/MCTD Over Dimension Permits Unit. These rates do not appear on the Table "B" chart. Contact OD Permits Unit, 503-373-0000 for those RUAF rates.

For additional record keeping requirements and tax reporting information, please see Instructions for Filing Highway-Use Tax Reports available on ODOT's Web site:

www.odot.state.or.us/trucking/regis/forms.htm

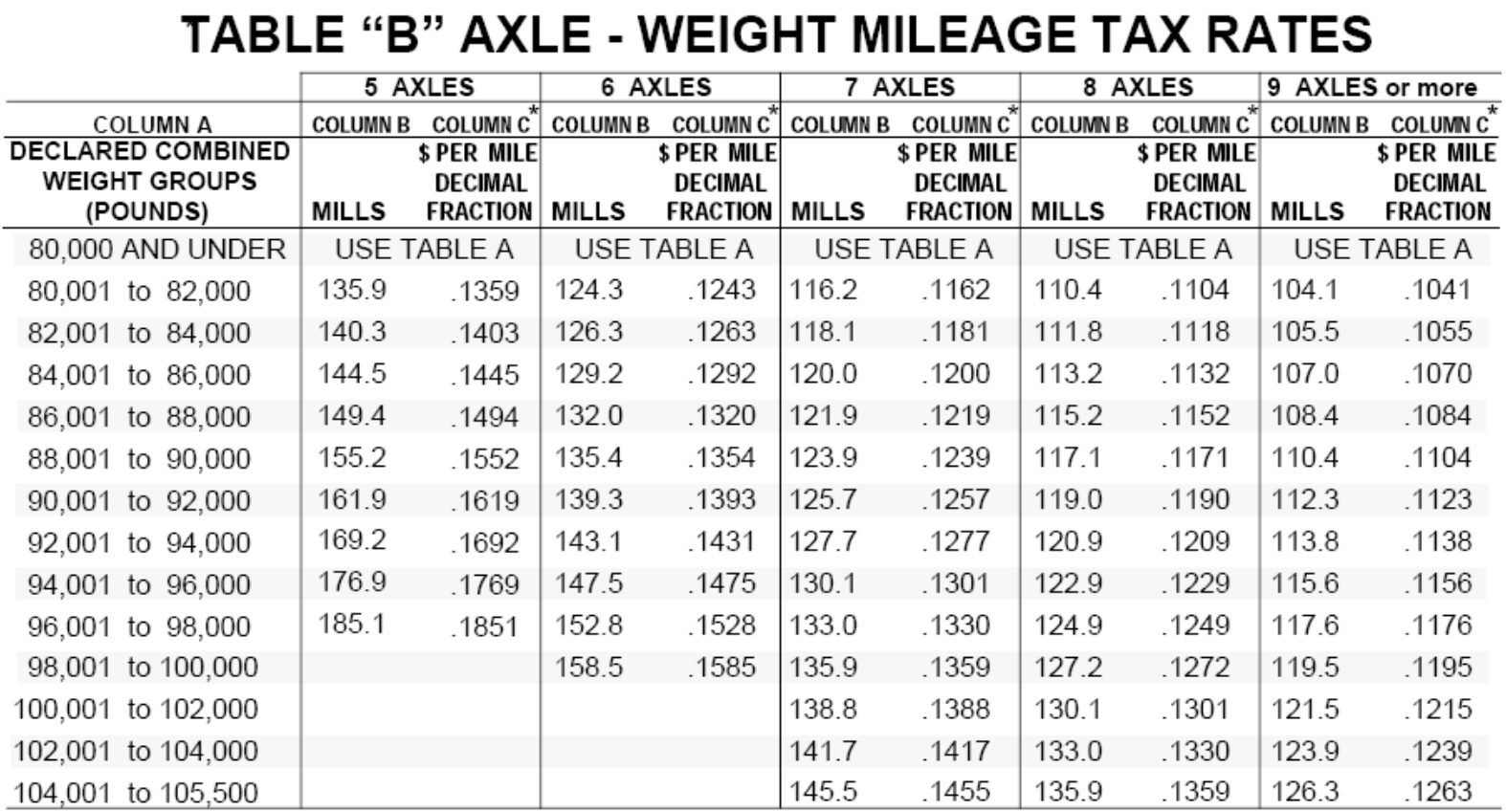

*NOTE - Column C converts mills per mile to dollars per mile by moving the decimal point three places to the left. Multiply the Oregon Taxable Miles by the decimal fraction for the amount of tax due for each weight.

\begin{tabular}{|c|c|c|c|c|c|c|}
\hline \multirow{3}{*}{ EXAMPLES: } & COLUMN A & NO. OF AXLES & COLUMN B & COLUMN C & TAX & \\
\hline & 96,000 & 5 & 176.9 & .1769 & $\begin{array}{r}1000 \text { Miles X. } .1769 \\
100 \text { Miles X } .1769\end{array}$ & $\begin{array}{l}=\$ 176.90 \\
=\quad 17.69\end{array}$ \\
\hline & 96,000 & 6 & 147.5 & .1475 & $\begin{array}{r}1000 \text { Miles X } .1475 \\
100 \text { Miles X } .1475\end{array}$ & $\begin{array}{l}=\$ 147.50 \\
=\quad 14.75\end{array}$ \\
\hline
\end{tabular}

SEE TABLE "A" RATES FOR 80,000 POUNDS AND UNDER.

Source: http://www.odot.state.or.us/forms/motcarr/reg/9225.pdf 


\section{Table "C"}

Oregon

Updated March 2009

Road Use Assessment Fees

- Cents Per Mile -

page 1 of 7

Oregon Road Use Assessment Fees - Cents per Mile

Gross Weight

98,000 to 100,000

100,001 to 102,000

102,001 to 104,000

104,001 to 106,000

106,001 to 108,000

108,001 to 110,000

110,001 to 112,000

112,001 to 114,000

114,001 to 116,000

116,001 to 118,000

118,001 to 120,000

120,001 to 122,000

122,001 to 124,000

124,001 to 126,000

126,001 to 128,000

128,001 to 130,000

130,001 to 132,000

132,001 to 134,000

134,001 to 136,000

136,001 to 138,000

138,001 to 140,000

140,001 to 142,000

142,001 to 144,000

144,001 to 146,000

146,001 to 148,000

148,001 to 150,000

150,001 to 152,000

152,001 to 154,000

154,001 to 156,000

156,001 to 158,000

158,001 to 160,000

160,001 to 162,000

162,001 to 164,000

164,001 to 166,000

166,001 to 168,000

168,001 to 170,000

170,001 to 172,000

172,001 to 174,000

174,001 to 176,000

176,001 to 178,000

178,001 to 180,000

180,001 to 182,000

182,001 to 184,000

184,001 to 186,000

186,001 to 188,000

188,001 to 190,000

190,001 to 192,000

192,001 to 194,000

194,001 to 196,000

196,001 to 198,000

198,001 to 200,000

200,001 to 202,000

202,001 to 204,000

204,001 to 206,000
Number of Axles

\begin{tabular}{|c|c|c|c|c|c|c|c|c|c|c|c|c|c|c|c|}
\hline \multicolumn{16}{|c|}{ Number of Axles } \\
\hline 5 & 6 & 7 & 8 & 9 & 10 & 11 & 12 & 13 & 14 & 15 & 16 & 17 & 18 & 19 & 20 \\
\hline 44 & 25 & 14 & 10 & 8 & 8 & 4 & 2 & 1 & 1 & 1 & 1 & 1 & 1 & 1 & 1 \\
\hline 49 & 27 & 15 & 10 & 9 & 8 & 4 & 2 & 2 & 2 & 2 & 1 & 1 & 1 & 1 & 1 \\
\hline 56 & 29 & 18 & 11 & 9 & 8 & 7 & 3 & 2 & 2 & 2 & 1 & 1 & 1 & 1 & 1 \\
\hline 64 & 31 & 19 & 12 & 10 & 9 & 7 & 3 & 2 & 2 & 2 & 1 & 1 & 1 & 1 & 1 \\
\hline 69 & 34 & 19 & 12 & 10 & 9 & 7 & 3 & 3 & 2 & 2 & 1 & 1 & 1 & 1 & 1 \\
\hline 79 & 36 & 21 & 13 & 10 & 9 & 8 & 4 & 3 & 2 & 2 & 1 & 1 & 1 & 1 & 1 \\
\hline 87 & 42 & 22 & 14 & 11 & 10 & 8 & 4 & 3 & 3 & 2 & 1 & 1 & 1 & 1 & 1 \\
\hline 93 & 43 & 23 & 15 & 12 & 10 & 9 & 4 & 3 & 3 & 2 & 1 & 1 & 1 & 1 & 1 \\
\hline 110 & 45 & 24 & 18 & 12 & 10 & 9 & 4 & 4 & 3 & 2 & 1 & 1 & 1 & 1 & 1 \\
\hline 124 & 49 & 26 & 19 & 13 & 10 & 9 & 7 & 4 & 3 & 2 & 1 & 1 & 1 & 1 & 1 \\
\hline 137 & 53 & 29 & 21 & 14 & 10 & 10 & 7 & 4 & 4 & 2 & 1 & 1 & 1 & 1 & 1 \\
\hline & 56 & 31 & 22 & 15 & 10 & 10 & 7 & 7 & 4 & 3 & 2 & 1 & 1 & 1 & 1 \\
\hline & 60 & 33 & 24 & 18 & 11 & 10 & 8 & 7 & 4 & 3 & 2 & 2 & 1 & 1 & 1 \\
\hline & 66 & 35 & 25 & 19 & 11 & 10 & 9 & 7 & 7 & 3 & 2 & 2 & 1 & 1 & 1 \\
\hline & 69 & 37 & 26 & 20 & 12 & 11 & 9 & 8 & 7 & 3 & 3 & 2 & 1 & 1 & 1 \\
\hline & 76 & 41 & 29 & 21 & 13 & 11 & 9 & 8 & 7 & 4 & 3 & 2 & 1 & 1 & 1 \\
\hline & 82 & 44 & 31 & 22 & 13 & 11 & 10 & 9 & 8 & 4 & 3 & 2 & 1 & 1 & 1 \\
\hline & 88 & 47 & 32 & 22 & 14 & 12 & 10 & 9 & 8 & 4 & 3 & 3 & 1 & 1 & 1 \\
\hline & 94 & 49 & 34 & 24 & 14 & 12 & 10 & 9 & 8 & 7 & 3 & 3 & 1 & 1 & 1 \\
\hline & 104 & 54 & 36 & 25 & 15 & 12 & 10 & 10 & 8 & 7 & 4 & 3 & 1 & 1 & 1 \\
\hline & 112 & 57 & 38 & 26 & 18 & 13 & 10 & 10 & 9 & 7 & 4 & 3 & 1 & 1 & 1 \\
\hline & 122 & 61 & 42 & 27 & 19 & 14 & 11 & 10 & 9 & 8 & 4 & 3 & 2 & 1 & 1 \\
\hline & & 66 & 45 & 30 & 20 & 14 & 11 & 10 & 9 & 8 & 7 & 4 & 2 & 1 & 1 \\
\hline & & 69 & 47 & 31 & 21 & 15 & 12 & 11 & 9 & 8 & 7 & 4 & 2 & 1 & 1 \\
\hline & & 75 & 48 & 32 & 22 & 18 & 13 & 11 & 10 & 9 & 8 & 4 & 3 & 2 & 1 \\
\hline & & 79 & 53 & 33 & 23 & 19 & 14 & 12 & 10 & 9 & 8 & 4 & 3 & 2 & 2 \\
\hline & & 83 & 55 & 35 & 24 & 19 & 14 & 12 & 10 & 10 & 8 & 4 & 4 & 2 & 2 \\
\hline & & 88 & 58 & 36 & 25 & 20 & 15 & 13 & 10 & 10 & 9 & 7 & 4 & 3 & 2 \\
\hline & & 92 & 60 & 38 & 26 & 21 & 18 & 13 & 10 & 10 & 9 & 7 & 4 & 3 & 2 \\
\hline & & 98 & 65 & 43 & 29 & 22 & 18 & 14 & 11 & 10 & 10 & 8 & 7 & 3 & 2 \\
\hline & & 103 & 67 & 45 & 30 & 23 & 19 & 14 & 12 & 11 & 10 & 8 & 7 & 4 & 3 \\
\hline & & 106 & 70 & 47 & 32 & 24 & 20 & 15 & 12 & 11 & 10 & 8 & 7 & 4 & 3 \\
\hline & & 113 & 76 & 49 & 33 & 25 & 21 & 15 & 13 & 11 & 10 & 9 & 8 & 4 & 3 \\
\hline & & 117 & 79 & 53 & 34 & 25 & 21 & 18 & 13 & 12 & 10 & 9 & 8 & 7 & 3 \\
\hline & & 124 & 82 & 56 & 36 & 27 & 22 & 18 & 14 & 13 & 11 & 9 & 9 & 7 & 4 \\
\hline & & 128 & 87 & 59 & 38 & 27 & 24 & 19 & 14 & 13 & 11 & 10 & 9 & 8 & 4 \\
\hline & & 135 & 90 & 61 & 42 & 30 & 25 & 19 & 14 & 14 & 11 & 10 & 10 & 8 & 4 \\
\hline & & 141 & 94 & 66 & 44 & 31 & 26 & 20 & 15 & 14 & 12 & 10 & 10 & 9 & 7 \\
\hline & & 147 & 101 & 68 & 45 & 32 & 27 & 21 & 18 & 15 & 12 & 10 & 10 & 9 & 7 \\
\hline & & 155 & 105 & 71 & 47 & 34 & 29 & 22 & 19 & 15 & 13 & 11 & 10 & 10 & 8 \\
\hline & & 160 & 109 & 76 & 48 & 35 & 30 & 22 & 19 & 18 & 13 & 11 & 11 & 10 & 8 \\
\hline & & & 114 & 79 & 54 & 37 & 32 & 24 & 20 & 18 & 14 & 11 & 11 & 10 & 8 \\
\hline & & & 121 & 82 & 55 & 38 & 33 & 24 & 21 & 19 & 14 & 12 & 12 & 10 & 9 \\
\hline & & & 125 & 87 & 57 & 42 & 34 & 25 & 22 & 19 & 15 & 13 & 12 & 10 & 9 \\
\hline & & & 132 & 89 & 59 & 43 & 36 & 26 & 22 & 20 & 15 & 13 & 12 & 10 & 10 \\
\hline & & & 137 & 93 & 64 & 45 & 37 & 27 & 23 & 21 & 18 & 14 & 13 & 11 & 10 \\
\hline & & & 144 & 98 & 66 & 47 & 41 & 29 & 24 & 21 & 18 & 14 & 13 & 11 & 10 \\
\hline & & & 149 & 102 & 68 & 48 & 42 & 31 & 24 & 22 & 19 & 15 & 13 & 12 & 10 \\
\hline & & & 156 & 105 & 70 & 52 & 44 & 32 & 25 & 22 & 19 & 15 & 14 & 12 & 10 \\
\hline & & & 162 & 110 & 75 & 54 & 45 & 33 & 26 & 23 & 20 & 18 & 14 & 12 & 10 \\
\hline & & & 169 & 113 & 78 & 56 & 47 & 34 & 27 & 23 & 20 & 18 & 15 & 13 & 11 \\
\hline & & & 174 & 117 & 81 & 58 & 48 & 35 & 29 & 24 & 21 & 19 & 15 & 13 & 11 \\
\hline & & & 182 & 123 & 84 & 60 & 49 & 37 & 30 & 25 & 21 & 19 & 18 & 13 & 11 \\
\hline & & & 189 & 126 & 88 & 65 & 53 & 38 & 31 & 25 & 22 & 20 & 18 & 14 & 12 \\
\hline
\end{tabular}

Source: http://www.oregon.gov/ODOT/MCT/docs/OregonRoadUseAssessmentFees.pdf 
Oregon

Updated March 2009

Road Use Assessment Fees

page 2 of 7

206,001 to 208,000 208,001 to 210,000 210,001 to 212,000

212,001 to 214,000

214,001 to 216,000 216,001 to 218,000 218,001 to 220,000 220,001 to 222,000

222,001 to 224,000 224,001 to 226,000 226,001 to 228,000 228,001 to 230,000 230,001 to 232,000 232,001 to 234,000 234,001 to 236,000 236,001 to 238,000 238,001 to 240,000 240,001 to 242,000 $\mathbf{2 4 2 , 0 0 1}$ to 244,000 244,001 to 246,000 246,001 to 248,000 248,001 to 250,000 250,001 to 252,000 252,001 to 254,000 254,001 to 256,000 256,001 to 258,000 258,001 to 260,000 260,001 to 262,000 262,001 to 264,000 264,001 to 266,000 266,001 to 268,000 268,001 to 270,000 270,001 to 272,000 272,001 to 274,000 274,001 to 276,000 276,001 to 278,000 278,001 to 280,000 280,001 to 282,000 282,001 to 284,000 284,001 to 286,000 286,001 to 288,000 288,001 to 290,000 290,001 to 292,000 292,001 to 294,000 294,001 to 296,000 296,001 to 298,000 298,001 to 300,000 300,001 to 302,000 302,001 to 304,000 304,001 to 306,000 306,001 to 308,000 308,001 to 310,000 310,001 to 312,000 312,001 to 314,000 314,001 to 316,000 316,001 to 318,000 318,001 to 320,000 320,001 to 322,000 322,001 to 324,000 324,001 to 326,000

\begin{tabular}{|c|c|c|c|c|c|c|c|c|c|c|c|c|c|c|c|}
\hline & & & 195 & 132 & \begin{tabular}{l|}
91 \\
\end{tabular} & \begin{tabular}{l|l|}
67 &
\end{tabular} & \begin{tabular}{l|l|}
54 \\
\end{tabular} & \begin{tabular}{l|l}
42 & \\
\end{tabular} & 32 & 26 & \begin{tabular}{l|l|}
23 \\
\end{tabular} & 21 & \begin{tabular}{l|l|}
18 \\
\end{tabular} & \begin{tabular}{l|l}
14 \\
\end{tabular} & 12 \\
\hline & & & 202 & 136 & 95 & \begin{tabular}{l|l|}
69 \\
\end{tabular} & 56 & \begin{tabular}{l|l}
43 \\
\end{tabular} & 33 & 27 & 23 & 21 & 19 & 14 & 12 \\
\hline & & & 209 & 141 & 101 & 71 & 58 & 44 & 34 & 27 & 24 & 22 & 20 & 15 & 13 \\
\hline & & & 218 & 146 & 104 & \begin{tabular}{l|l}
76 \\
\end{tabular} & \begin{tabular}{l|l}
60 \\
\end{tabular} & $\begin{array}{ll}46 \\
\end{array}$ & 35 & 29 & 25 & 23 & 20 & 15 & 13 \\
\hline & & & 226 & 150 & \begin{tabular}{ll|}
110 \\
\end{tabular} & 79 & \begin{tabular}{l|l|}
64 &
\end{tabular} & \begin{tabular}{|l|l}
48 & \\
\end{tabular} & 37 & \begin{tabular}{l|l|}
30 & \\
\end{tabular} & \begin{tabular}{|l|l|}
25 & \\
\end{tabular} & \begin{tabular}{|l|l|}
23 & \\
\end{tabular} & 20 & \begin{tabular}{l|l|}
15 & \\
\end{tabular} & 14 \\
\hline & & & 232 & 157 & 114 & \begin{tabular}{l|l}
82 & \\
\end{tabular} & \begin{tabular}{l|l}
66 & \\
\end{tabular} & \begin{tabular}{|l|l|}
49 &
\end{tabular} & 38 & 31 & \begin{tabular}{|l|l|}
26 & \\
\end{tabular} & 24 & 21 & \begin{tabular}{l|l|}
18 & \\
\end{tabular} & 14 \\
\hline & & & 240 & 162 & \begin{tabular}{l|l}
118 \\
\end{tabular} & \begin{tabular}{l|l|}
87 &
\end{tabular} & \begin{tabular}{l|l|}
67 &
\end{tabular} & \begin{tabular}{l|l}
52 \\
\end{tabular} & 42 & \begin{tabular}{l|l|}
32 \\
\end{tabular} & 27 & 25 & 21 & \begin{tabular}{l|l}
18 \\
\end{tabular} & 15 \\
\hline & & & 249 & 169 & 124 & 89 & 69 & \begin{tabular}{|l|l}
53 \\
\end{tabular} & 43 & 33 & 27 & 26 & 22 & 18 & 15 \\
\hline & & & 259 & 175 & 127 & \begin{tabular}{l|l}
92 \\
\end{tabular} & 71 & 55 & \begin{tabular}{l|}
45 \\
\end{tabular} & 34 & 29 & 26 & 23 & 19 & 15 \\
\hline & & & & 182 & 134 & \begin{tabular}{l|l}
98 \\
\end{tabular} & 75 & \begin{tabular}{l|}
57 \\
\end{tabular} & $\begin{array}{ll}46 \\
\end{array}$ & 35 & 30 & 27 & 23 & 19 & 18 \\
\hline & & & & 190 & 139 & 101 & 78 & \begin{tabular}{l|l}
59 \\
\end{tabular} & \begin{tabular}{l|l}
48 \\
\end{tabular} & 37 & 30 & 29 & 24 & 20 & 18 \\
\hline & & & & 196 & 146 & 105 & 80 & 61 & 49 & 38 & 31 & 29 & 24 & 20 & 19 \\
\hline & & & & 205 & 151 & 110 & 82 & 64 & 53 & 41 & 32 & 30 & 25 & 20 & 19 \\
\hline & & & & 214 & \begin{tabular}{l|l|}
158 \\
\end{tabular} & \begin{tabular}{l|l|}
113 \\
\end{tabular} & 84 & \begin{tabular}{l|l}
66 \\
\end{tabular} & 55 & \begin{tabular}{l|l}
42 \\
\end{tabular} & \begin{tabular}{l|l}
33 \\
\end{tabular} & 30 & 25 & 21 & 20 \\
\hline & & & & 220 & 163 & \begin{tabular}{l|l}
118 \\
\end{tabular} & \begin{tabular}{|l|}
87 \\
\end{tabular} & \begin{tabular}{|l|}
67 \\
\end{tabular} & \begin{tabular}{l|l|}
57 \\
\end{tabular} & 44 & \begin{tabular}{|l|l|}
33 & \\
\end{tabular} & 31 & \begin{tabular}{|l|l|}
26 & \\
\end{tabular} & 21 & 20 \\
\hline & & & & 230 & 172 & 124 & 90 & 69 & 60 & $\begin{array}{ll}46 \\
\end{array}$ & 34 & 32 & 26 & 22 & 21 \\
\hline & & & & 240 & 181 & 127 & 93 & 71 & 64 & 48 & 35 & 33 & 27 & 22 & 21 \\
\hline & & & & 249 & 189 & 130 & 96 & \begin{tabular}{l|l}
73 \\
\end{tabular} & 66 & \begin{tabular}{l|l}
49 \\
\end{tabular} & 36 & 34 & 29 & 23 & 22 \\
\hline & & & & 258 & $\begin{array}{ll}196 \\
\end{array}$ & 134 & 100 & \begin{tabular}{l|}
76 \\
\end{tabular} & 68 & \begin{tabular}{l|}
52 \\
\end{tabular} & 37 & 35 & 30 & 24 & 22 \\
\hline & & & & 266 & 204 & \begin{tabular}{l|l|}
137 &
\end{tabular} & 103 & \begin{tabular}{l|l}
78 \\
\end{tabular} & 70 & \begin{tabular}{l|l|}
53 &
\end{tabular} & 38 & 36 & 31 & 25 & 23 \\
\hline & & & & 275 & 212 & 140 & 106 & 80 & 72 & 55 & 39 & 37 & 32 & 26 & 23 \\
\hline & & & & 284 & 219 & 144 & 110 & 82 & 75 & 56 & 41 & 38 & 33 & 27 & 24 \\
\hline & & & & 293 & 227 & \begin{tabular}{l|l|}
147 &
\end{tabular} & \begin{tabular}{l|l|}
113 \\
\end{tabular} & 84 & 77 & \begin{tabular}{l|}
58 \\
\end{tabular} & \begin{tabular}{l|l}
42 \\
\end{tabular} & 39 & 34 & 29 & 24 \\
\hline & & & & 301 & 235 & 150 & \begin{tabular}{|l|l|}
116 \\
\end{tabular} & \begin{tabular}{|l|}
87 \\
\end{tabular} & 79 & \begin{tabular}{l|l|}
59 \\
\end{tabular} & 43 & 41 & \begin{tabular}{|l|}
35 \\
\end{tabular} & 30 & 25 \\
\hline & & & & 310 & 242 & \begin{tabular}{|l|}
153 \\
\end{tabular} & \begin{tabular}{|l|}
119 \\
\end{tabular} & \begin{tabular}{l|l|}
89 & \\
\end{tabular} & 81 & 61 & 44 & \begin{tabular}{l|}
42 \\
\end{tabular} & 36 & 31 & 25 \\
\hline & & & & 319 & 250 & \begin{tabular}{l|l}
158 \\
\end{tabular} & 123 & 91 & \begin{tabular}{|l|}
83 \\
\end{tabular} & \begin{tabular}{l|l}
62 \\
\end{tabular} & \begin{tabular}{l|l}
45 \\
\end{tabular} & \begin{tabular}{l|l}
43 \\
\end{tabular} & \begin{tabular}{l|l|}
37 \\
\end{tabular} & 32 & 26 \\
\hline & & & & 328 & 258 & \begin{tabular}{l|}
162 \\
\end{tabular} & 126 & 93 & 86 & \begin{tabular}{l|l|}
65 \\
\end{tabular} & \begin{tabular}{l|l}
46 \\
\end{tabular} & 44 & \begin{tabular}{l|l}
38 \\
\end{tabular} & \begin{tabular}{l|l}
33 \\
\end{tabular} & 26 \\
\hline & & & & 337 & 264 & \begin{tabular}{l|}
167 \\
\end{tabular} & 129 & 95 & 88 & 66 & \begin{tabular}{l|}
47 \\
\end{tabular} & \begin{tabular}{l|l}
45 \\
\end{tabular} & 39 & 34 & 27 \\
\hline & & & & 345 & 272 & \begin{tabular}{l|}
171 \\
\end{tabular} & \begin{tabular}{l|l|}
133 \\
\end{tabular} & \begin{tabular}{l|l}
98 \\
\end{tabular} & 90 & 68 & \begin{tabular}{l|l}
48 \\
\end{tabular} & \begin{tabular}{l|l}
46 \\
\end{tabular} & 41 & \begin{tabular}{l|l|}
35 \\
\end{tabular} & 27 \\
\hline & & & & 354 & 278 & 175 & 136 & 100 & 92 & 69 & 49 & 47 & 42 & 36 & 29 \\
\hline & & & & 363 & 286 & 180 & 139 & 102 & 94 & 71 & 50 & 48 & 43 & 37 & 29 \\
\hline & & & & 372 & 293 & 184 & \begin{tabular}{l|l|}
143 \\
\end{tabular} & 104 & 96 & 72 & \begin{tabular}{l|l}
52 \\
\end{tabular} & \begin{tabular}{l|}
49 \\
\end{tabular} & \begin{tabular}{l|l|}
44 \\
\end{tabular} & 38 & 30 \\
\hline & & & & 380 & 300 & 189 & 146 & 106 & \begin{tabular}{l|}
99 \\
\end{tabular} & \begin{tabular}{l|l}
75 \\
\end{tabular} & \begin{tabular}{l|l}
53 \\
\end{tabular} & 50 & \begin{tabular}{l|l}
45 \\
\end{tabular} & 39 & 31 \\
\hline & & & & 389 & 307 & \begin{tabular}{|l|}
193 \\
\end{tabular} & 149 & 109 & 101 & 76 & 54 & 52 & 46 & 41 & 32 \\
\hline & & & & 398 & 315 & \begin{tabular}{l|}
197 \\
\end{tabular} & 152 & 111 & \begin{tabular}{l|l}
103 \\
\end{tabular} & \begin{tabular}{|l|l|}
78 \\
\end{tabular} & \begin{tabular}{l|l}
55 \\
\end{tabular} & \begin{tabular}{l|}
53 \\
\end{tabular} & \begin{tabular}{l|l|}
47 \\
\end{tabular} & 42 & 33 \\
\hline & & & & 407 & 322 & 202 & 156 & 113 & 105 & \begin{tabular}{l|l}
80 \\
\end{tabular} & \begin{tabular}{|l|l}
56 & \\
\end{tabular} & 54 & 48 & 43 & 34 \\
\hline & & & & 415 & 329 & 206 & 159 & 115 & $\begin{array}{l}107 \\
\end{array}$ & \begin{tabular}{l|l|}
82 & \\
\end{tabular} & 57 & 55 & \begin{tabular}{l|l}
49 \\
\end{tabular} & 44 & 35 \\
\hline & & & & 424 & 337 & 210 & \begin{tabular}{l|l}
162 \\
\end{tabular} & \begin{tabular}{l|l}
118 \\
\end{tabular} & 110 & 84 & \begin{tabular}{l|l}
58 \\
\end{tabular} & 56 & 50 & \begin{tabular}{l|l|}
45 & \\
\end{tabular} & 36 \\
\hline & & & & 433 & 344 & 215 & 166 & 122 & 112 & 87 & 59 & 57 & 52 & 45 & 37 \\
\hline & & & & 442 & 351 & 219 & 169 & 125 & 114 & 89 & 60 & 58 & 53 & 46 & 38 \\
\hline & & & & 451 & 358 & 225 & \begin{tabular}{l|}
172 \\
\end{tabular} & \begin{tabular}{l|}
127 \\
\end{tabular} & 116 & 91 & 61 & \begin{tabular}{l|}
59 \\
\end{tabular} & \begin{tabular}{l|l|}
54 \\
\end{tabular} & \begin{tabular}{l|l}
47 \\
\end{tabular} & 39 \\
\hline & & & & 459 & 365 & 230 & \begin{tabular}{|l|}
175 \\
\end{tabular} & \begin{tabular}{|l|l|}
130 & \\
\end{tabular} & 118 & \begin{tabular}{l|l}
93 & \\
\end{tabular} & \begin{tabular}{l|l}
62 & \\
\end{tabular} & 60 & \begin{tabular}{l|l}
55 \\
\end{tabular} & \begin{tabular}{|l|}
47 \\
\end{tabular} & 41 \\
\hline & & & & 468 & 372 & 236 & \begin{tabular}{|l|}
179 \\
\end{tabular} & 134 & 121 & \begin{tabular}{c|}
95 \\
\end{tabular} & 64 & 61 & \begin{tabular}{|l|}
56 \\
\end{tabular} & \begin{tabular}{l|l}
48 \\
\end{tabular} & 42 \\
\hline & & & & 477 & \begin{tabular}{l|}
378 \\
\end{tabular} & 241 & \begin{tabular}{l|}
182 \\
\end{tabular} & \begin{tabular}{l|}
137 \\
\end{tabular} & \begin{tabular}{l|l|}
123 \\
\end{tabular} & \begin{tabular}{l|}
96 \\
\end{tabular} & $\begin{array}{ll}65 \\
\end{array}$ & 62 & \begin{tabular}{l|}
57 \\
\end{tabular} & 49 & 43 \\
\hline & & & & 487 & 386 & 248 & 185 & 139 & 125 & \begin{tabular}{|l|}
98 \\
\end{tabular} & \begin{tabular}{l|l}
66 & \\
\end{tabular} & 64 & \begin{tabular}{l|l}
58 & \\
\end{tabular} & 49 & 44 \\
\hline & & & & 497 & 392 & 254 & 189 & \begin{tabular}{l|l|}
143 \\
\end{tabular} & $\begin{array}{l}127 \\
\end{array}$ & \begin{tabular}{l|l|}
99 \\
\end{tabular} & 67 & 65 & \begin{tabular}{l|l}
59 \\
\end{tabular} & 50 & 45 \\
\hline & & & & 506 & 399 & 261 & \begin{tabular}{l|l}
192 \\
\end{tabular} & \begin{tabular}{l|l}
146 \\
\end{tabular} & \begin{tabular}{l|l|}
129 \\
\end{tabular} & 100 & \begin{tabular}{l|l|}
68 \\
\end{tabular} & 66 & 60 & \begin{tabular}{l|l}
52 \\
\end{tabular} & 46 \\
\hline & & & & 516 & 406 & 267 & 195 & 149 & 132 & 102 & 69 & 67 & 61 & 53 & 47 \\
\hline & & & & 526 & 412 & 274 & 198 & 152 & 134 & 104 & 70 & 68 & 62 & 54 & 48 \\
\hline & & & & 536 & 419 & 281 & 202 & \begin{tabular}{|l|}
156 \\
\end{tabular} & 136 & 105 & \begin{tabular}{|l|}
71 \\
\end{tabular} & 69 & 64 & \begin{tabular}{l|l|}
55 & \\
\end{tabular} & 49 \\
\hline & & & & 546 & \begin{tabular}{l|l}
426 \\
\end{tabular} & 287 & 205 & \begin{tabular}{l|l|}
158 \\
\end{tabular} & \begin{tabular}{l|}
138 \\
\end{tabular} & 107 & \begin{tabular}{l|l}
72 \\
\end{tabular} & 70 & 65 & 56 & 50 \\
\hline & & & & 556 & \begin{tabular}{|l|}
433 \\
\end{tabular} & 294 & 208 & 161 & 140 & $\begin{array}{ll}109 \\
\end{array}$ & \begin{tabular}{|l|l|}
73 & \\
\end{tabular} & 71 & 66 & \begin{tabular}{|l|}
57 \\
\end{tabular} & 52 \\
\hline & & & & 566 & \begin{tabular}{ll|}
440 \\
\end{tabular} & 300 & 212 & \begin{tabular}{l|}
163 \\
\end{tabular} & $\begin{array}{ll}143 \\
\end{array}$ & 110 & 75 & 72 & 67 & 58 & 53 \\
\hline & & & & 575 & 446 & \begin{tabular}{|c|}
307 \\
\end{tabular} & 215 & 164 & 145 & 112 & \begin{tabular}{|l|l|}
76 &
\end{tabular} & 73 & 68 & \begin{tabular}{|l|l|}
59 & \\
\end{tabular} & 54 \\
\hline & & & & 585 & \begin{tabular}{l|l|}
453 &
\end{tabular} & 314 & 218 & \begin{tabular}{l|l}
168 \\
\end{tabular} & 147 & 114 & 77 & 75 & 69 & 59 & 55 \\
\hline & & & & 595 & \begin{tabular}{|l|}
459 \\
\end{tabular} & 320 & 221 & \begin{tabular}{l|}
171 \\
\end{tabular} & \begin{tabular}{l|}
149 \\
\end{tabular} & 116 & 79 & 76 & 70 & 60 & 56 \\
\hline & & & & 605 & $\begin{array}{ll}467 \\
\end{array}$ & 327 & 225 & 174 & 151 & \begin{tabular}{l|l|}
119 \\
\end{tabular} & 81 & 77 & 71 & 61 & 57 \\
\hline & & & & 615 & 475 & 333 & 228 & 178 & 153 & 122 & 82 & 79 & 72 & 62 & 58 \\
\hline & & & & 625 & 482 & 340 & 231 & 181 & 156 & 123 & 84 & 80 & 73 & 64 & 59 \\
\hline & & & & 635 & \begin{tabular}{|l|}
491 \\
\end{tabular} & 346 & 236 & 184 & \begin{tabular}{l|l|}
158 \\
\end{tabular} & 124 & 86 & \begin{tabular}{l|}
82 \\
\end{tabular} & 75 & 65 & 60 \\
\hline
\end{tabular}


Oregon

Updated March 2009

Road Use Assessment Fees

page 3 of 7

326,001 to 328,000 328,001 to 330,000 330,001 to 332,000 332,001 to 334,000 334,001 to 336,000 336,001 to 338,000 338,001 to 340,000 340,001 to 342,000 342,001 to 344,000 344,001 to 346,000 346,001 to 348,000 348,001 to 350,000 350,001 to 352,000 352,001 to 354,000 354,001 to 356,000 356,001 to 358,000 358,001 to 360,000 360,001 to 362,000 362,001 to 364,000 364,001 to 366,000 366,001 to 368,000 368,001 to 370,000 370,001 to 372,000 372,001 to 374,000 374,001 to 376,000 376,001 to 378,000 378,001 to 380,000 380,001 to 382,000 382,001 to 384,000 384,001 to 386,000 386,001 to 388,000 388,001 to 390,000 390,001 to 392,000 392,001 to 394,000 394,001 to 396,000 396,001 to 398,000 398,001 to 400,000 400,001 to 402,000 402,001 to 404,000 404,001 to 406,000 406,001 to 408,000 408,001 to 410,000 410,001 to 412,000 412,001 to 414,000 414,001 to 416,000 416,001 to 418,000 418,001 to 420,000 $\mathbf{4 2 0 , 0 0 1}$ to 422,000 422,001 to 424,000 $\mathbf{4 2 4 , 0 0 1}$ to 426,000 426,001 to 428,000 428,001 to 430,000 430,001 to 432,000 432,001 to 434,000 $\mathbf{4 3 4 , 0 0 1}$ to 436,000 436,001 to 438,000 438,001 to 440,000 440,001 to 442,000 442,001 to 444,000 444,001 to 446,000

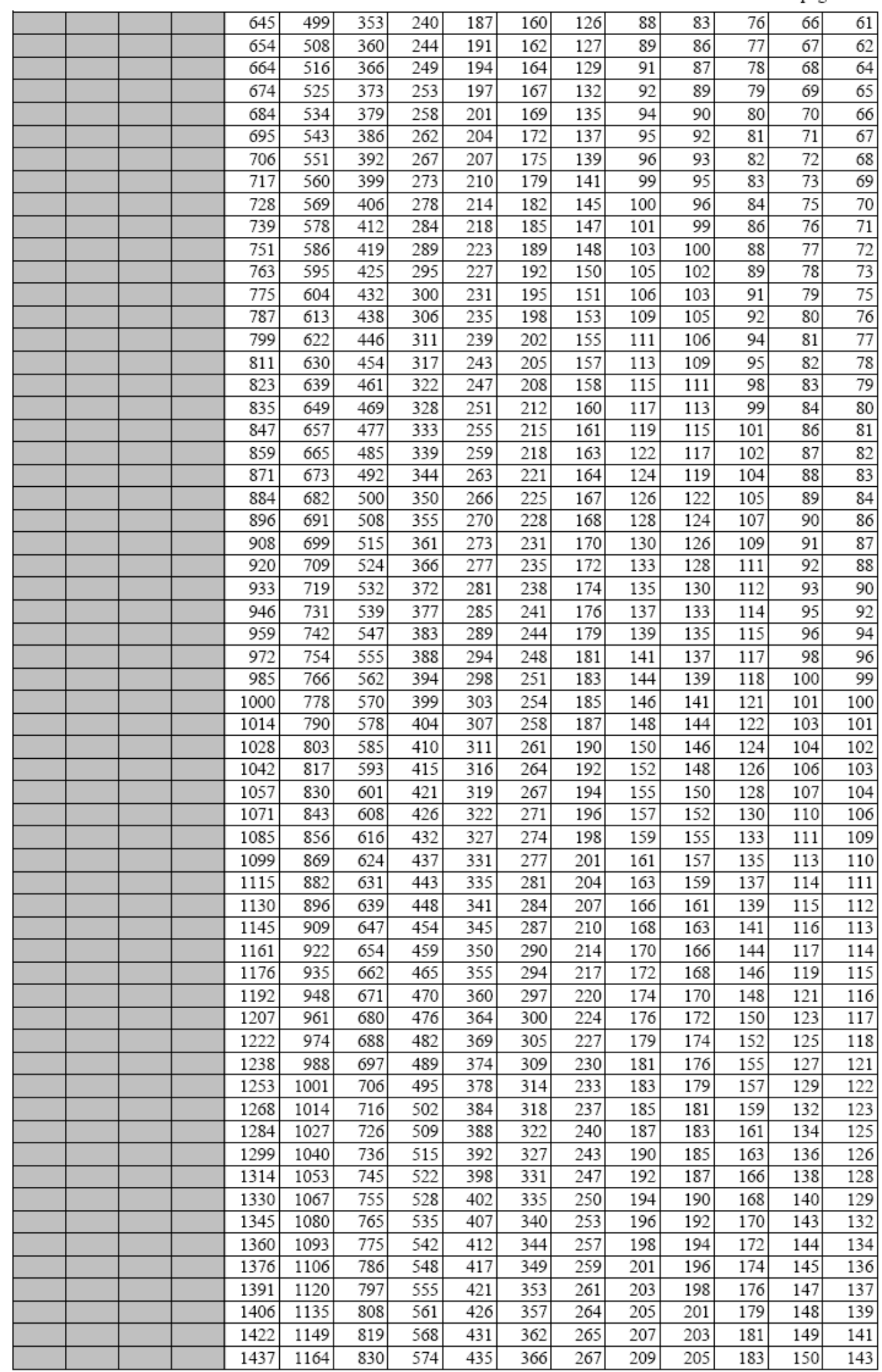


Oregon

Updated March 2009

Road Use Assessment Fees

page 4 of 7

446,001 to 448,000

448,001 to 450,000

450,001 to 452,000

$\mathbf{4 5 2 , 0 0 1}$ to 454,000

$\mathbf{4 5 4 , 0 0 1}$ to 456,000

456,001 to 458,000

458,001 to 460,000

460,001 to 462,000

462,001 to 464,000

464,001 to 466,000

466,001 to 468,000

468,001 to 470,000

470,001 to 472,000

472,001 to 474,000

$\mathbf{4 7 4 , 0 0 1}$ to 476,000

476,001 to 478,000

478,001 to 480,000

480,001 to 482,000

482,001 to 484,000

484,001 to 486,000

486,001 to 488,000

488,001 to 490,000

490,001 to 492,000

492,001 to 494,000

494,001 to 496,000

496,001 to 498,000

498,001 to 500,000

$\mathbf{5 0 0 , 0 0 1}$ to $\mathbf{5 0 2 , 0 0 0}$

$\mathbf{5 0 2 , 0 0 1}$ to 504,000

$\mathbf{5 0 4 , 0 0 1}$ to 506,000

$\mathbf{5 0 6 , 0 0 1}$ to $\mathbf{5 0 8 , 0 0 0}$

$\mathbf{5 0 8 , 0 0 1}$ to $\mathbf{5 1 0 , 0 0 0}$

510,001 to 512,000

$\mathbf{5 1 2 , 0 0 1}$ to $\mathbf{5 1 4 , 0 0 0}$

$\mathbf{5 1 4 , 0 0 1}$ to 516,000

$\mathbf{5 1 6 , 0 0 1}$ to 518,000

$\mathbf{5 1 8 , 0 0 1}$ to $\mathbf{5 2 0 , 0 0 0}$

$\mathbf{5 2 0 , 0 0 1}$ to $\mathbf{5 2 2 , 0 0 0}$

$\mathbf{5 2 2 , 0 0 1}$ to $\mathbf{5 2 4 , 0 0 0}$

$\mathbf{5 2 4 , 0 0 1}$ to $\mathbf{5 2 6 , 0 0 0}$

$\mathbf{5 2 6 , 0 0 1}$ to $\mathbf{5 2 8 , 0 0 0}$

$\mathbf{5 2 8 , 0 0 1}$ to $\mathbf{5 3 0 , 0 0 0}$

$\mathbf{5 3 0 , 0 0 1}$ to $\mathbf{5 3 2 , 0 0 0}$

$\mathbf{5 3 2 , 0 0 1}$ to $\mathbf{5 3 4 , 0 0 0}$

$\mathbf{5 3 4 , 0 0 1}$ to $\mathbf{5 3 6 , 0 0 0}$

$\mathbf{5 3 6 , 0 0 1}$ to $\mathbf{5 3 8 , 0 0 0}$

$\mathbf{5 3 8 , 0 0 1}$ to $\mathbf{5 4 0 , 0 0 0}$

$\mathbf{5 4 0 , 0 0 1}$ to $\mathbf{5 4 2 , 0 0 0}$

$\mathbf{5 4 2 , 0 0 1}$ to $\mathbf{5 4 4 , 0 0 0}$

$\mathbf{5 4 4 , 0 0 1}$ to $\mathbf{5 4 6 , 0 0 0}$

$\mathbf{5 4 6 , 0 0 1}$ to $\mathbf{5 4 8 , 0 0 0}$

$\mathbf{5 4 8 , 0 0 1}$ to $\mathbf{5 5 0 , 0 0 0}$

$\mathbf{5 5 0 , 0 0 1}$ to $\mathbf{5 5 2 , 0 0 0}$

$\mathbf{5 5 2 , 0 0 1}$ to $\mathbf{5 5 4 , 0 0 0}$

$\mathbf{5 5 4 , 0 0 1}$ to $\mathbf{5 5 6 , 0 0 0}$

\begin{tabular}{|l|l|l|}
$\mathbf{5 5 6 , 0 0 1}$ & to 558,000 \\
\hline
\end{tabular}

\begin{tabular}{|l|l|l|}
\hline $\mathbf{5 5 8 , 0 0 1}$ & to & $\mathbf{5 6 0 , 0 0 0}$
\end{tabular}

$\mathbf{5 6 0 , 0 0 1}$ to $\mathbf{5 6 2 , 0 0 0}$

$\mathbf{5 6 2 , 0 0 1}$ to 564,000

564,001 to 566,000

- Cents Per Mile -

\begin{tabular}{|c|c|c|c|c|c|c|c|c|c|c|c|c|c|c|c|}
\hline & & & & 1454 & 1179 & 841 & 581 & 441 & 371 & 270 & 212 & 207 & 185 & \begin{tabular}{|l|}
151 \\
\end{tabular} & 145 \\
\hline & & & & 1470 & 1195 & 852 & 588 & 446 & 375 & 272 & 214 & 209 & 187 & 152 & 146 \\
\hline & & & & 1486 & 1210 & \begin{tabular}{|l|}
863 \\
\end{tabular} & 594 & 452 & 379 & 275 & 216 & 212 & 190 & 155 & 148 \\
\hline & & & & 1503 & 1226 & 874 & 601 & 457 & 384 & 278 & 218 & 214 & 192 & 157 & 150 \\
\hline & & & & 1519 & 1241 & 885 & 607 & 463 & 388 & 282 & 220 & 216 & 194 & 159 & 151 \\
\hline & & & & 1536 & 1256 & 896 & 614 & 468 & 392 & 285 & 223 & 218 & \begin{tabular}{|l|}
196 \\
\end{tabular} & \begin{tabular}{|l|}
161 \\
\end{tabular} & 153 \\
\hline & & & & 1552 & 1273 & 907 & 620 & 474 & 397 & 288 & 225 & 220 & 198 & 163 & 156 \\
\hline & & & & 1569 & 1289 & 917 & 627 & 479 & 401 & 292 & 227 & 223 & 201 & 166 & 158 \\
\hline & & & & 1585 & 1306 & 928 & 634 & 485 & 406 & 295 & 229 & 225 & 203 & \begin{tabular}{l|l|}
168 \\
\end{tabular} & 160 \\
\hline & & & & 1601 & 1322 & 939 & 640 & 490 & 410 & 298 & 231 & 227 & 205 & 170 & 162 \\
\hline & & & & 1618 & 1338 & 950 & 647 & 495 & 414 & 301 & 233 & 229 & 207 & 172 & 164 \\
\hline & & & & 1635 & 1355 & 961 & 653 & 501 & 420 & 305 & 236 & 231 & 209 & 174 & 167 \\
\hline & & & & 1653 & 1371 & 973 & 660 & 506 & 425 & 308 & 238 & 233 & 212 & 176 & 169 \\
\hline & & & & 1671 & \begin{tabular}{c|}
1388 \\
\end{tabular} & \begin{tabular}{|c|}
985 \\
\end{tabular} & 666 & 512 & 431 & 311 & 240 & \begin{tabular}{|l|}
236 \\
\end{tabular} & 214 & \begin{tabular}{|l|}
179 \\
\end{tabular} & 171 \\
\hline & & & & 1688 & 1404 & \begin{tabular}{|l|l|}
998 \\
\end{tabular} & 673 & 517 & 436 & 315 & 242 & 238 & 216 & 181 & 173 \\
\hline & & & & 1706 & 1421 & 1010 & 680 & 523 & 442 & 318 & 244 & 240 & 218 & 183 & 175 \\
\hline & & & & 1723 & 1437 & 1022 & 686 & 528 & 447 & 321 & 247 & 242 & 220 & 185 & 178 \\
\hline & & & & 1741 & 1454 & 1034 & 693 & 534 & 453 & 324 & 249 & 244 & 223 & 187 & 180 \\
\hline & & & & 1758 & 1470 & 1046 & 700 & 539 & 458 & 328 & 251 & 247 & 225 & 190 & 182 \\
\hline & & & & 1776 & 1486 & 1058 & 708 & 545 & 464 & 331 & 253 & 249 & 227 & 192 & 184 \\
\hline & & & & 1793 & 1503 & 1070 & 716 & 550 & 469 & 334 & 255 & 251 & 229 & 194 & 186 \\
\hline & & & & 1811 & 1519 & 1082 & 723 & 556 & 475 & 338 & 258 & 253 & 231 & 196 & 189 \\
\hline & & & & 1828 & 1536 & 1094 & 731 & 561 & 480 & 341 & 260 & 255 & 233 & \begin{tabular}{l|l}
198 \\
\end{tabular} & 191 \\
\hline & & & & 1846 & 1553 & 1106 & 739 & 567 & 486 & 344 & 262 & 258 & 236 & 201 & 193 \\
\hline & & & & 1863 & 1571 & \begin{tabular}{|l|}
1119 \\
\end{tabular} & 746 & 572 & 491 & 347 & 264 & 260 & 238 & 203 & 195 \\
\hline & & & & 1881 & 1588 & \begin{tabular}{|l|}
1132 \\
\end{tabular} & 754 & 578 & 497 & 351 & 266 & 262 & 240 & 205 & 197 \\
\hline & & & & 1899 & 1606 & 1145 & 762 & 583 & 502 & 354 & 269 & 264 & 242 & 207 & 200 \\
\hline & & & & 1916 & 1624 & \begin{tabular}{|l|}
1158 \\
\end{tabular} & 770 & 589 & 508 & 358 & 272 & 266 & 245 & 210 & 203 \\
\hline & & & & 1934 & 1640 & 1170 & 777 & 594 & 513 & 361 & 274 & 269 & 247 & 212 & 205 \\
\hline & & & & 1953 & 1657 & \begin{tabular}{|l|}
1182 \\
\end{tabular} & 785 & 600 & 518 & 364 & 277 & 272 & 249 & 214 & 207 \\
\hline & & & & 1972 & 1673 & 1194 & 793 & 606 & 524 & 368 & 280 & 274 & 252 & 216 & 209 \\
\hline & & & & 1991 & 1690 & 1206 & 801 & 612 & 529 & 371 & 282 & 277 & 254 & 219 & 211 \\
\hline & & & & 2011 & 1707 & 1219 & 809 & 619 & 534 & 375 & 285 & 279 & 257 & 221 & 214 \\
\hline & & & & 2030 & 1724 & 1231 & 816 & 625 & 540 & 378 & 288 & 282 & 259 & 223 & 216 \\
\hline & & & & 2049 & 1741 & 1243 & 824 & 631 & 545 & 382 & 290 & 285 & 262 & 225 & 218 \\
\hline & & & & 2069 & 1759 & 1255 & 832 & 637 & 551 & 385 & 293 & \begin{tabular}{l|}
287 \\
\end{tabular} & 264 & 227 & 220 \\
\hline & & & & 2088 & 1776 & 1268 & 840 & 643 & 556 & 389 & 296 & 290 & 267 & 230 & 222 \\
\hline & & & & & & & & & & & 299 & 293 & 269 & 232 & 224 \\
\hline & & & & & & & & & & & 301 & 295 & 272 & 234 & 226 \\
\hline & & & & & & & & & & & 304 & 298 & 274 & 237 & 229 \\
\hline & & & & & & & & & & & 307 & 301 & 277 & 239 & 231 \\
\hline & & & & & & & & & & & 310 & 304 & 279 & 241 & 233 \\
\hline & & & & & & & & & & & 312 & 306 & 282 & 243 & 235 \\
\hline & & & & & & & & & & & 315 & 309 & 284 & 246 & 238 \\
\hline & & & & & & & & & & & 318 & 312 & 287 & 248 & 240 \\
\hline & & & & & & & & & & & 321 & 315 & 289 & 250 & 242 \\
\hline & & & & & & & & & & & 324 & 318 & 292 & 253 & 244 \\
\hline & & & & & & & & & & & 327 & 320 & 295 & 255 & 247 \\
\hline & & & & & & & & & & & 330 & 323 & 297 & 258 & 249 \\
\hline & & & & & & & & & & & 333 & 326 & 300 & 260 & 251 \\
\hline & & & & & & & & & & & 335 & 329 & 303 & 262 & 254 \\
\hline & & & & & & & & & & & 338 & 332 & 305 & 265 & 256 \\
\hline & & & & & & & & & & & 341 & 335 & 308 & 267 & 258 \\
\hline & & & & & & & & & & & 344 & 338 & 311 & 270 & 260 \\
\hline & & & & & & & & & & & 346 & 340 & 313 & 272 & 263 \\
\hline & & & & & & & & & & & 349 & 343 & 316 & 274 & 265 \\
\hline & & & & & & & & & & & 352 & 346 & 319 & 277 & 268 \\
\hline & & & & & & & & & & & 355 & 349 & 321 & 279 & 270 \\
\hline & & & & & & & & & & & 358 & 352 & 324 & 282 & 272 \\
\hline & & & & & & & & & & & 362 & 354 & 327 & 284 & 275 \\
\hline
\end{tabular}


Oregon

Updated March 2009

Road Use Assessment Fees

- Cents Per Mile -

page 5 of 7

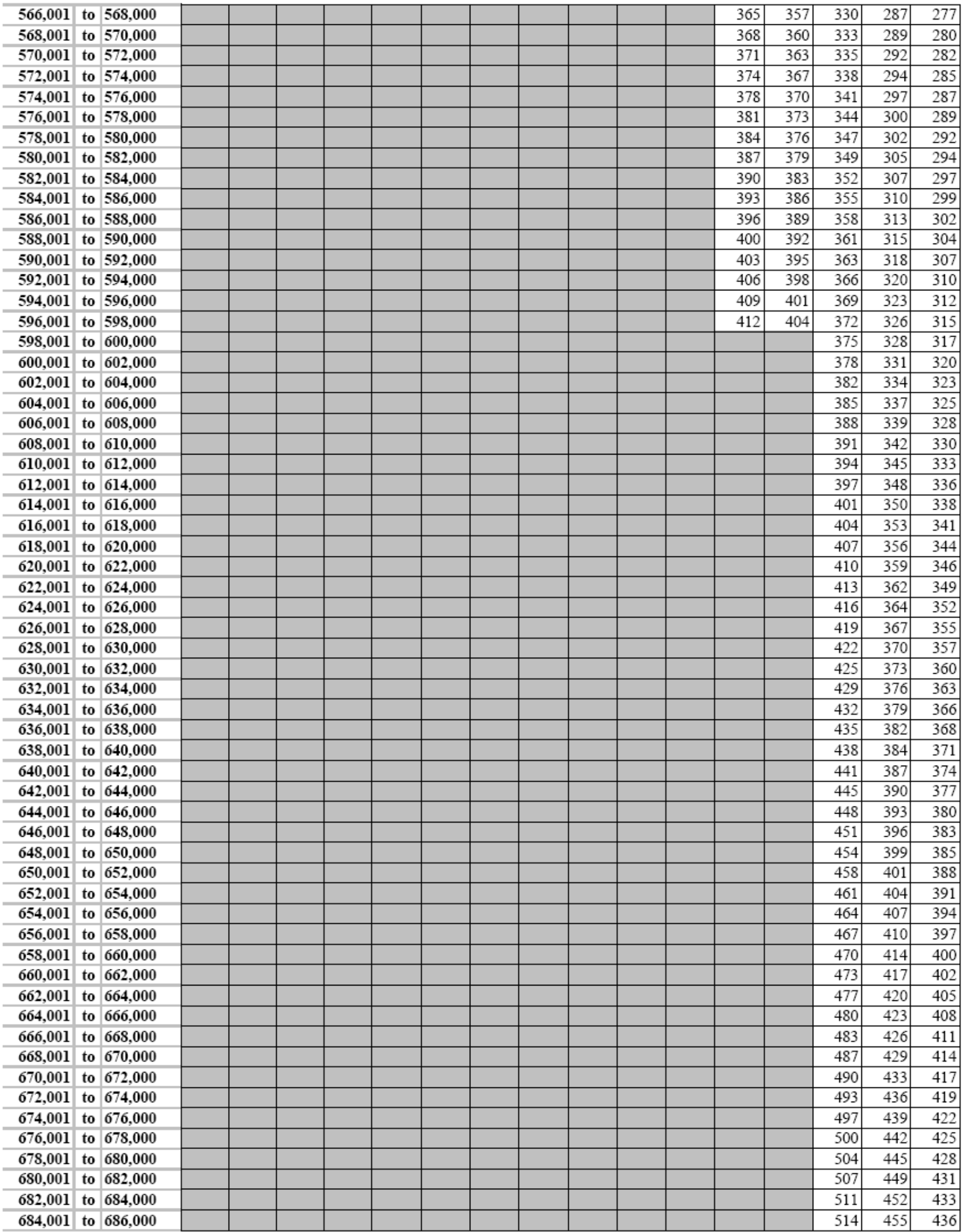




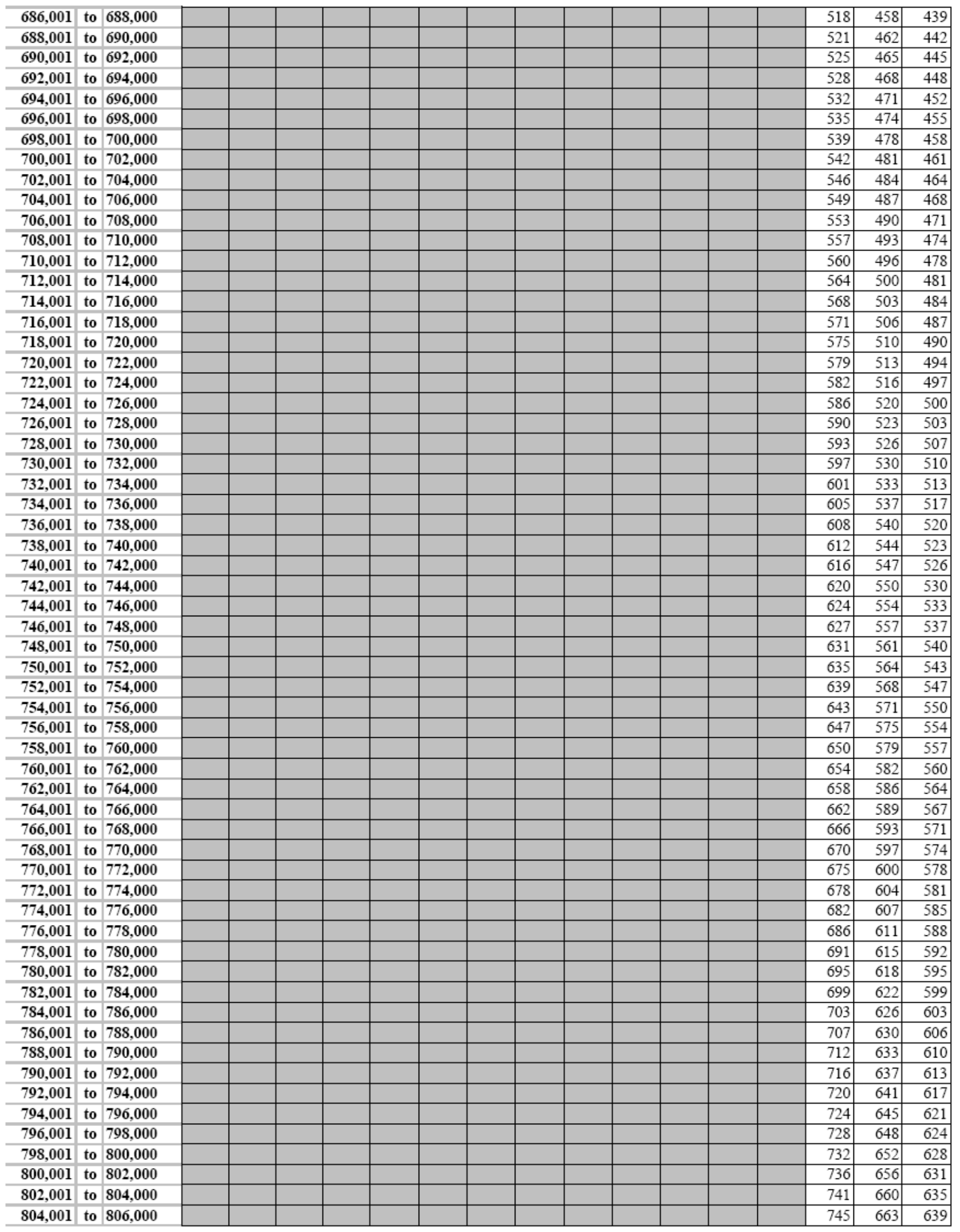


Oregon

Updated March 2009

Road Use Assessment Fees

page 7 of 7

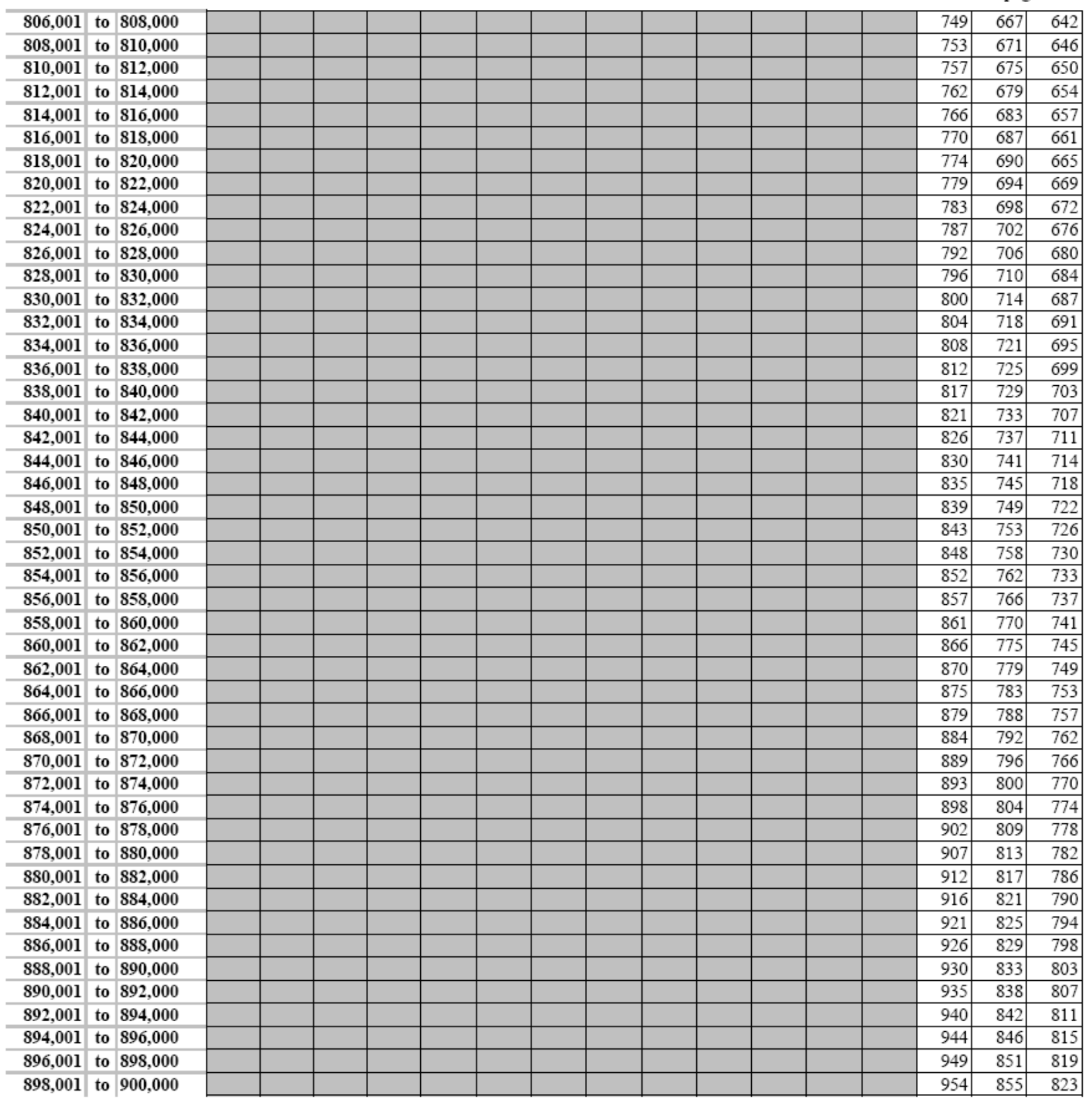




\section{APPENDIX 6: UNIT PAVEMENT COSTS (USDOT, 2000)}

The unit pavement costs reported in USDOT (2000) are given in Table 1 and Table 2. It is to be noted that the damage cost estimates from that study are so low that they are unrealistic. Thus, we do not recommend their use in establishing the costs of pavement damage. We herein present them only for purposes of comparison between the effects of truck types, number of axles, and road classes on pavement damage.

Table 1: Unit Pavement Cost For Various Truck Types (\$/1000 miles) (USDOT, 2000).

\begin{tabular}{|c|c|c|c|c|c|c|c|c|c|c|}
\hline \multicolumn{11}{|c|}{ Unit Pavement Cost for Various Truck Types in $\$ / 1,000$ miles } \\
\hline & \multirow{4}{*}{$\begin{array}{l}\text { Weights (Pounds) } \\
\text { GVW }\end{array}$} & \multicolumn{9}{|c|}{ Truck Type } \\
\hline & & \multicolumn{2}{|c|}{ Single-Unit } & \multicolumn{2}{|c|}{ Semitrailer } & \multicolumn{3}{|c|}{ Double-Trailer } & \multirow{2}{*}{\multicolumn{2}{|c|}{$\frac{\text { Triple-Trailer }}{\text { 7-Axles }}$}} \\
\hline & & \multirow{2}{*}{$\frac{\text { 3-Axles }}{54,000}$} & \multirow{2}{*}{$\frac{\text { 4-Axles }}{64,000}$} & \multirow{2}{*}{$\frac{\text { 5-Axles }}{80,000}$} & \multirow{2}{*}{$\frac{\text { 6-Axles }}{90,000}$} & \multirow{2}{*}{$\frac{\text { 5-Axles }}{80,000}$} & \multirow{2}{*}{$\frac{\text { 7-Axles }}{100,000}$} & \multirow{2}{*}{$\frac{\text { 8-Axles }}{105,000}$} & & \\
\hline & & & & & & & & & 100,000 & 115,000 \\
\hline & Tare & 22,600 & 26,400 & 30.49 & 31,530 & 29,320 & 38,600 & 33,470 & 41,700 & 41,700 \\
\hline & Payload & 31,400 & 37,600 & 49,510 & 58,470 & 50,680 & 61,400 & 71,530 & 58,300 & 73,300 \\
\hline Area Type & Functional Class & & & & & & & & & \\
\hline & & & & & & & & & & \\
\hline \multirow[t]{6}{*}{ Rural } & Interstate & 0.09 & 0.07 & 0.05 & 0.05 & 0.03 & 0.1 & 0.05 & 0.04 & 0.08 \\
\hline & Prin.Art. & 0.17 & 0.16 & 0.12 & 0.11 & 0.07 & 0.15 & 0.1 & 0.17 & 0.31 \\
\hline & Min.Art. & 0.37 & 0.33 & 0.29 & 0.22 & 0.32 & 0.41 & 0.21 & 0.39 & 0.75 \\
\hline & Maj.Col. & 1.38 & 1.35 & 0.9 & 0.8 & 1.17 & 1.03 & 0.65 & 1.46 & 2.95 \\
\hline & Min.Col. & 2.27 & 2.08 & 1.49 & 1.24 & 1.92 & 1.69 & 1.07 & 2.42 & 4.87 \\
\hline & Locals & 5.9 & 5.63 & 3.87 & 3.23 & 4.99 & 4.4 & 2.79 & 6.27 & 12.6 \\
\hline \multirow[t]{6}{*}{ Urban } & Interstate & 0.06 & 0.04 & 0.04 & 0.04 & 0.03 & 0.04 & 0.02 & 0.03 & 0.05 \\
\hline & Freeway\&Expressway & 0.09 & 0.06 & 0.06 & 0.05 & 0.04 & 0.07 & 0.04 & 0.09 & 0.18 \\
\hline & Prin.Art. & 0.13 & 0.12 & 0.1 & 0.09 & 0.11 & 0.09 & 0.06 & 0.13 & 0.26 \\
\hline & Min.Art. & 0.3 & 0.24 & 0.22 & 0.17 & 0.19 & 0.18 & 0.12 & 0.34 & 0.7 \\
\hline & Collector & 0.66 & 0.7 & 0.54 & 0.49 & 0.46 & 0.34 & 0.25 & 0.86 & 1.82 \\
\hline & Locals & 2.34 & 2.53 & 1.91 & 1.75 & 1.64 & 1.19 & 0.88 & 3.06 & 6.45 \\
\hline
\end{tabular}

Table 2: Unit Cost per Payload-mile for Various Truck Types (\$/1000 Ton-miles) (USDOT, 2000).

\begin{tabular}{|c|c|c|c|c|c|c|c|c|c|c|}
\hline \multicolumn{11}{|c|}{ Unit Cost per Payload-mile for Various Truck Types in $\$ / 1,000$ Ton-miles } \\
\hline & \multirow[b]{3}{*}{ Weights (Pounds) } & \multicolumn{9}{|c|}{ Truck Type } \\
\hline & & \multicolumn{2}{|c|}{ Single-Unit } & \multicolumn{2}{|c|}{ Semitrailer } & \multicolumn{3}{|c|}{ Double-Trailer } & \multirow{2}{*}{\multicolumn{2}{|c|}{$\frac{\text { Triple-Trailer }}{\text { 7-Axles }}$}} \\
\hline & & \multirow{2}{*}{$\frac{\text { 3-Axles }}{54,000}$} & \multirow{2}{*}{$\frac{\text { 4-Axles }}{64,000}$} & \multirow{2}{*}{$\frac{\text { 5-Axles }}{80,000}$} & \multirow{2}{*}{$\frac{\text { 6-Axles }}{90,000}$} & \multirow{2}{*}{$\frac{\text { 5-Axles }}{80,000}$} & \multirow{2}{*}{$\frac{\text { 7-Axles }}{100,000}$} & \multirow{2}{*}{$\frac{\text { 8-Axles }}{105,000}$} & & \\
\hline & GVW & & & & & & & & 100,000 & 115,000 \\
\hline & Tare & 22,600 & 26,400 & 30.49 & 31,530 & 29,320 & 38,600 & 33,470 & 41,700 & 41,700 \\
\hline & Payload & 31,400 & 37,600 & 49,510 & 58,470 & 50,680 & 61,400 & 71,530 & 58,300 & 73,300 \\
\hline Area Type & Functional Class & & & & & & & & & \\
\hline & & & & & & & & & & \\
\hline \multirow[t]{6}{*}{ Rural } & Interstate & 0.006 & 0.004 & 0.002 & 0.002 & 0.001 & 0.003 & 0.001 & 0.001 & 0.002 \\
\hline & Prin.Art. & 0.011 & 0.009 & 0.005 & 0.004 & 0.003 & 0.005 & 0.003 & 0.006 & 0.008 \\
\hline & Min.Art. & 0.024 & 0.018 & 0.012 & 0.008 & 0.013 & 0.013 & 0.006 & 0.013 & 0.02 \\
\hline & Maj.Col. & 0.088 & 0.072 & 0.036 & 0.027 & 0.046 & 0.034 & 0.018 & 0.05 & 0.08 \\
\hline & Min.Col. & 0.145 & 0.111 & 0.06 & 0.042 & 0.076 & 0.055 & 0.03 & 0.083 & 0.133 \\
\hline & Locals & 0.376 & 0.299 & 0.156 & 0.11 & 0.197 & 0.143 & 0.078 & 0.215 & 0.344 \\
\hline \multirow[t]{6}{*}{ Urban } & Interstate & 0.004 & 0.002 & 0.002 & 0.001 & 0.001 & 0.001 & 0.001 & 0.001 & 0.001 \\
\hline & Freeway\&Expressway & 0.006 & 0.003 & 0.002 & 0.002 & 0.002 & 0.002 & 0.001 & 0.003 & 0.005 \\
\hline & Prin.Art. & 0.008 & 0.006 & 0.004 & 0.003 & 0.004 & 0.003 & 0.002 & 0.004 & 0.007 \\
\hline & Min.Art. & 0.019 & 0.013 & 0.009 & 0.006 & 0.007 & 0.006 & 0.003 & 0.011 & 0.019 \\
\hline & Collector & 0.042 & 0.037 & 0.022 & 0.017 & 0.018 & 0.011 & 0.007 & 0.03 & 0.05 \\
\hline & Locals & 0.149 & 0.136 & 0.077 & 0.06 & 0.065 & 0.039 & 0.024 & 0.105 & 0.176 \\
\hline
\end{tabular}


With due attention to the caveat stated in the introduction to this Appendix, Tables 1 and 2 also illustrate how the addition of axles allows for increased payloads and at the same time reduces pavement deterioration (or conversely, how the reduction of axles at a given payloads could increase pavement deterioration). It is particularly interesting to see the comparisons between the 3-and 4-axle single unit trucks; the 5- and 6-axle semitrailer combinations; and the 5- and 8-axle double trailers. As seen in the results, the cost (\$/payload ton-mile) for the 4 -axle truck is approximately $75 \%$ of that for the 3 -axle truck even though its gross weight is 10,000 pounds more than the 3-axle truck. Also, a comparison of the 6-axle semitrailer with the 5-axle is very similar on non-Interstate highways. It is also seen that the costs for the 8 -axle doubletrailer are less than half those for the 5-axle double-trailer. The data also suggests that triple trailers do not compare well with double trailers. While additional axles cause less damage to the pavement, truck owners seem to be opposed to adding axles because this increases the tare weight of the vehicle and causes increases in the cost of vehicle operation.

Table 3 presents the pavement damage cost implications of increasing the number of axles. It can be seen that adding even just one axle has significant reduction of pavement damage cost. While the decrease in pavement cost for adding more than one axle is no expected to be linear, one nevertheless can expect a very drastic impact on pavement damage costs.

Table 3: Increase in Axle Load for Rural Interstate Operations (USDOT, 2000).

\begin{tabular}{|cccc|} 
& Change from & To & Impact on Pavement Damage Cost \\
\hline $\begin{array}{c}\text { Double Trailer } \\
\text { GVW 100-105K lbs }\end{array}$ & 7 axles & 8 axles & $50 \%$ reduction \\
\hline $\begin{array}{c}\text { Semi-Trailer } \\
\text { GVW 80-90K Ibs }\end{array}$ & 5 axles & 6 axles & $40 \%$ reduction \\
\hline
\end{tabular}



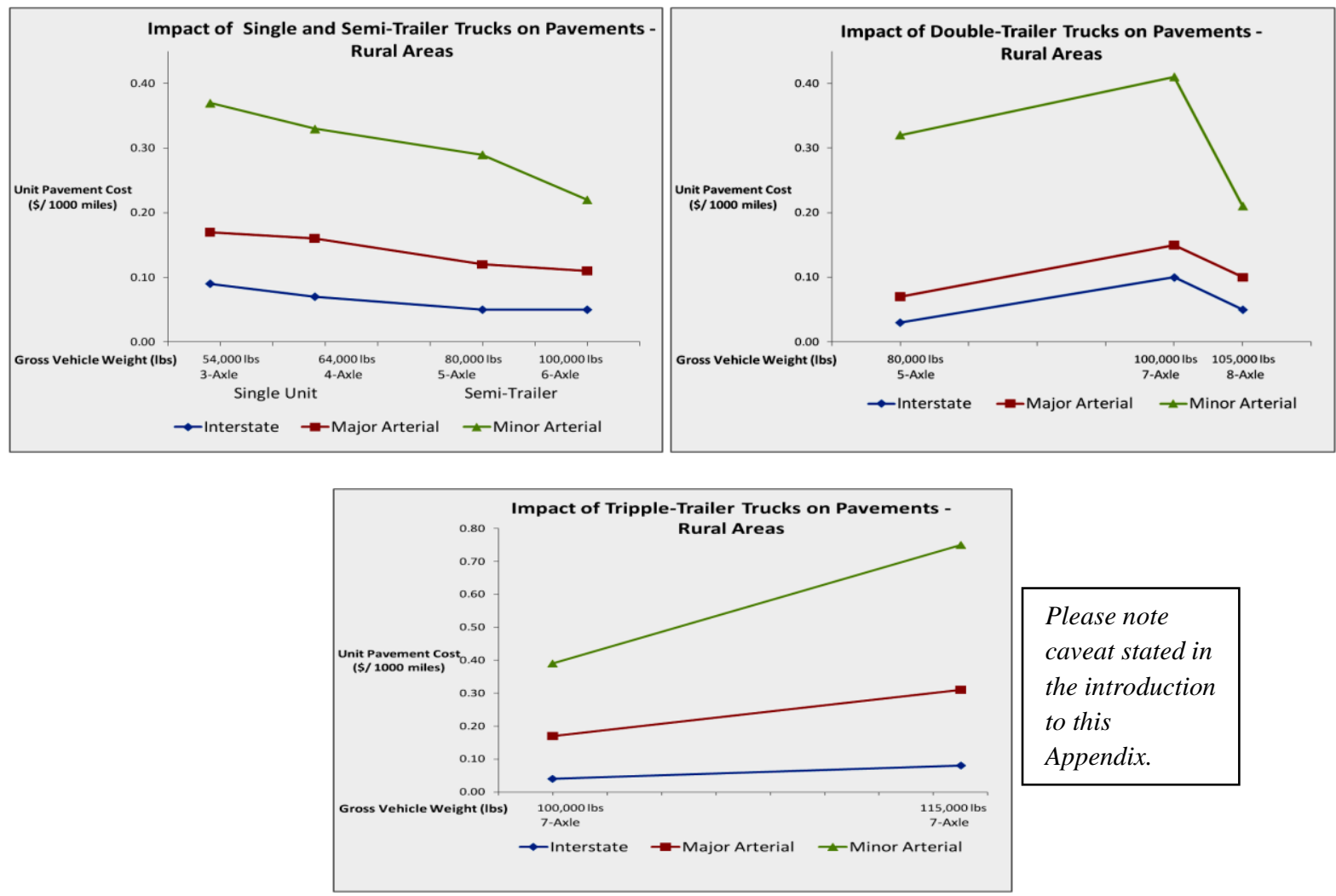

Please note caveat stated in the introduction to this Appendix.

Figure 1: Unit Pavement Cost For Various Truck Types ( $\$ / 1000$ miles), Rural Roads
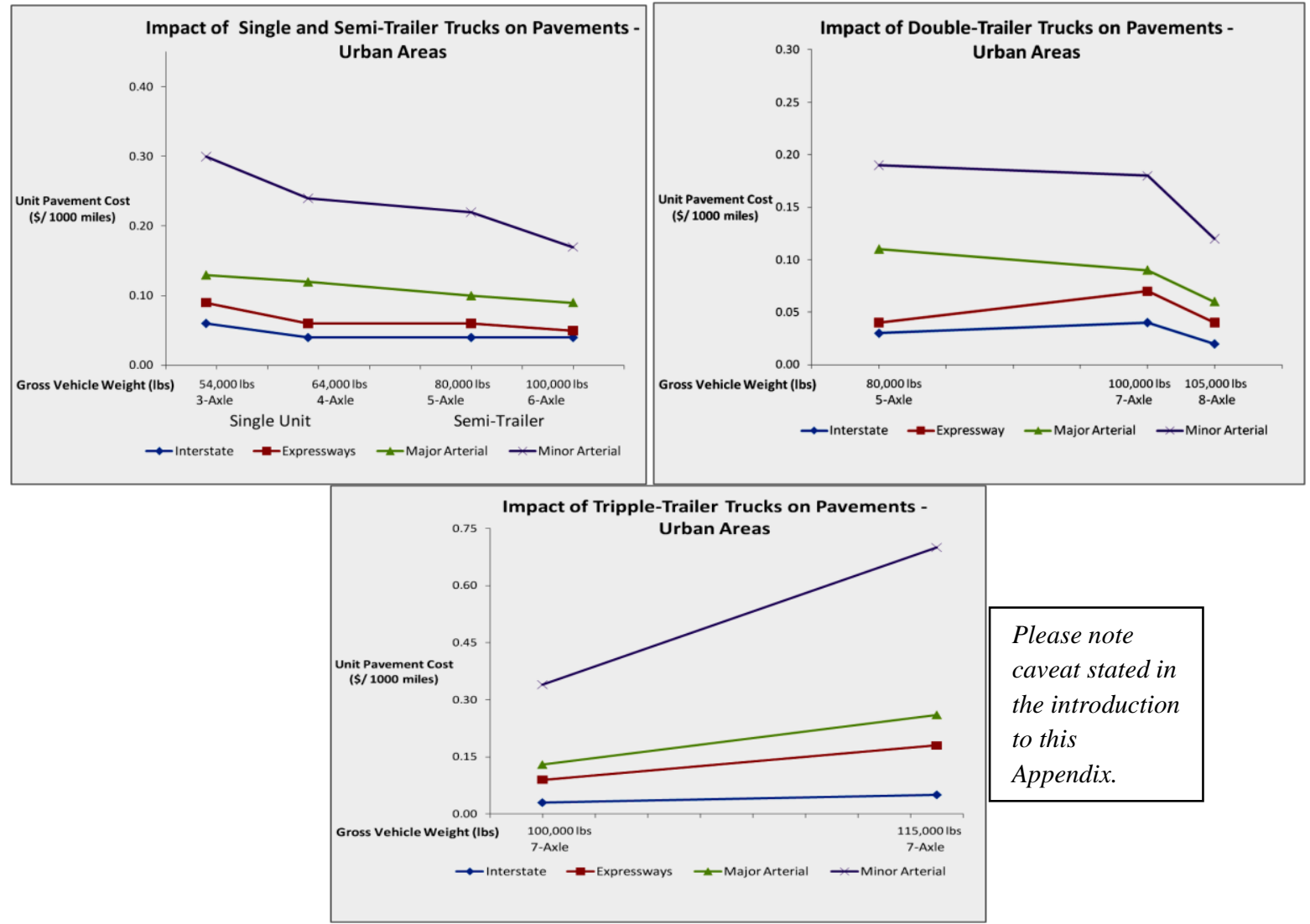

Please note caveat stated in the introduction to this Appendix. 


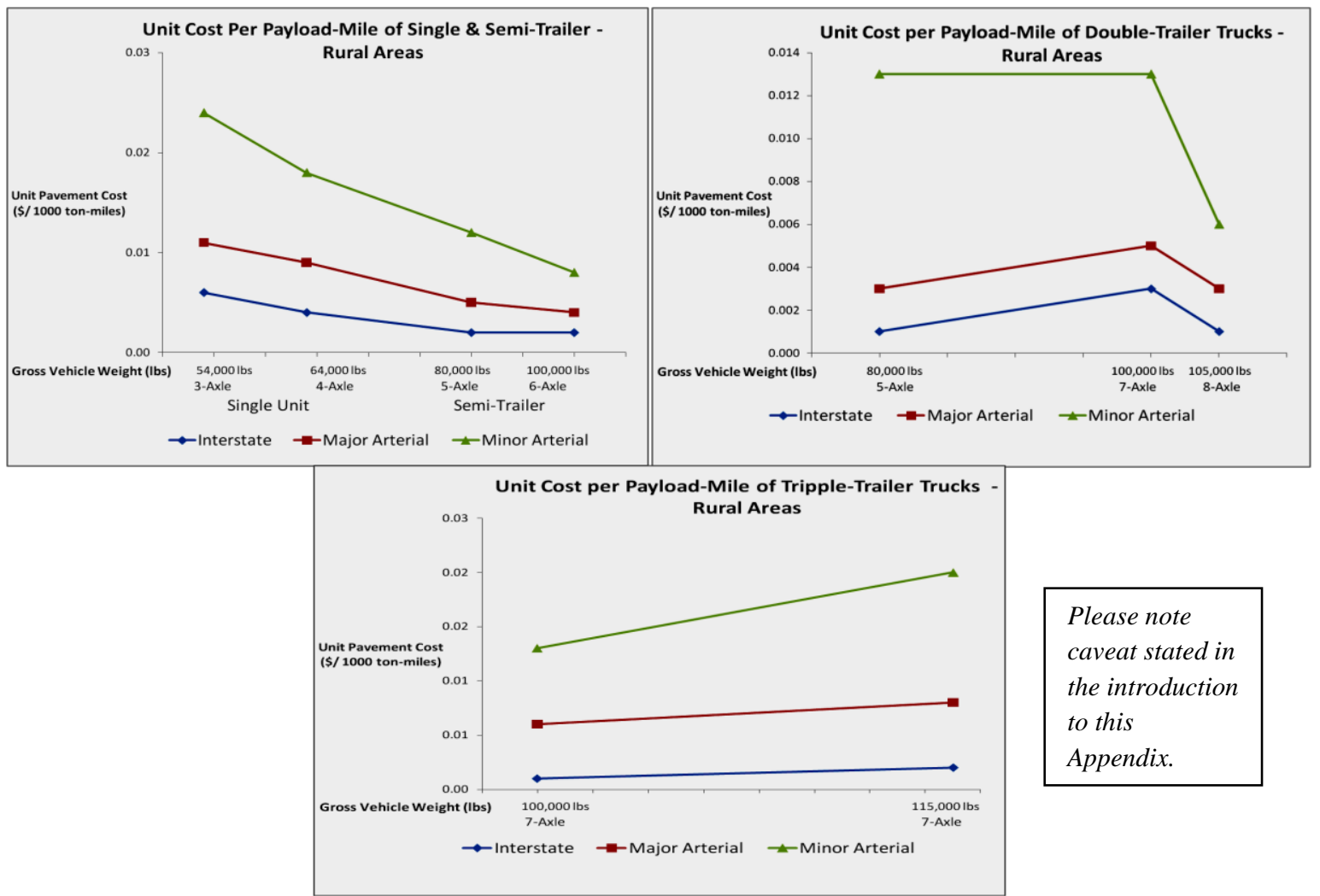

Figure 3: Unit Cost per Payload-mile for Various Truck Types (\$/1000 Ton-miles), Rural

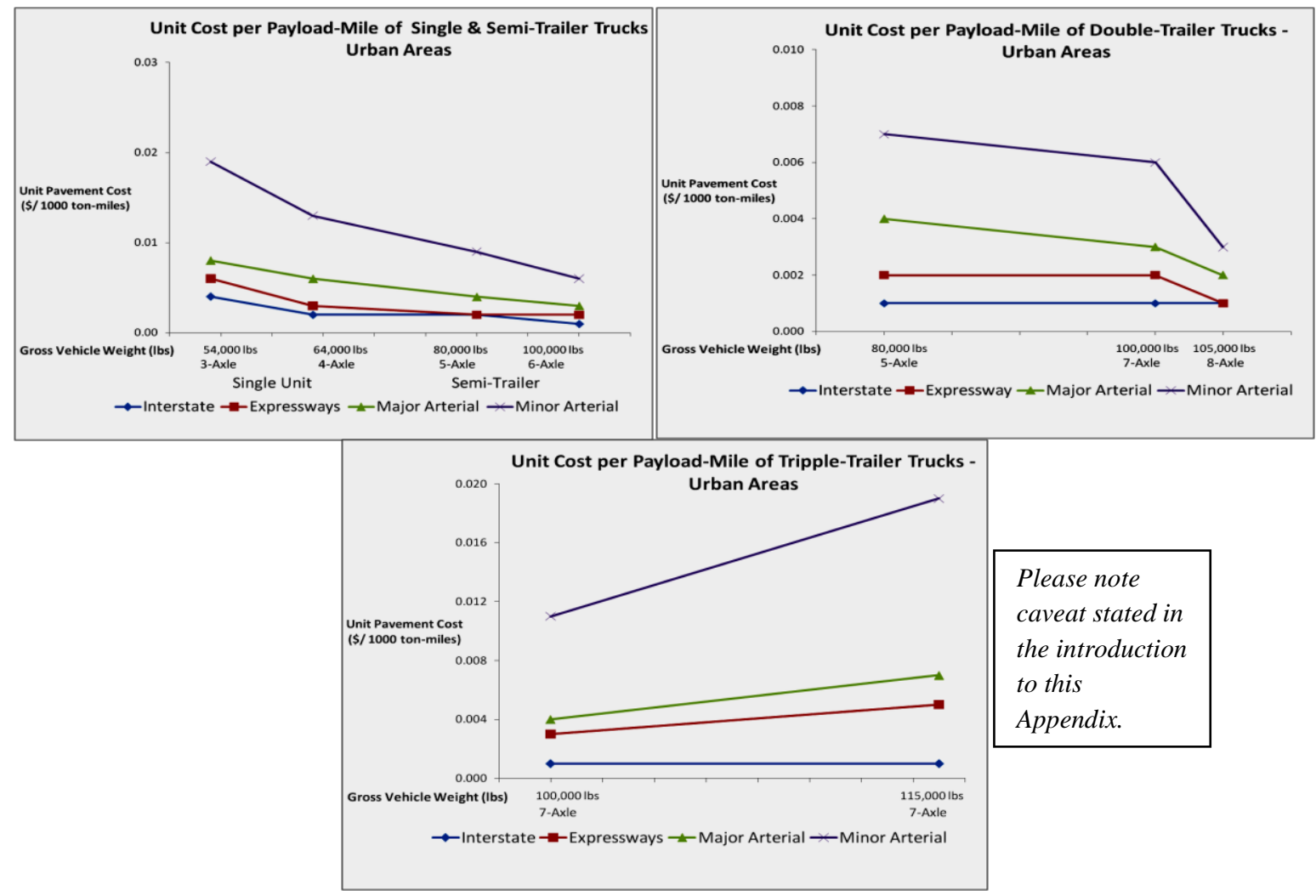

Figure 4: Unit Cost per Payload-mile for Various Truck Types (\$/1000 Ton-miles), Urban 